This report was prepared as an account of work sponsored by the United States Government. Neithor the United States not the United States Atomic Energy Commission, nor any of their employees, nor any of their contractors, subcontractors, or theif employees, makes any warranty, express or implied, or assumes any legal 1iability or responsibility for the accuracy. completeness or usefulness of any information, apparatus, product or process disclosed, or tepresents that its use would not infringe privately owned rights. 


\section{DISCLAIMER}

This report was prepared as an account of work sponsored by an agency of the United States Government. Neither the United States Government nor any agency Thereof, nor any of their employees, makes any warranty, express or implied, or assumes any legal liability or responsibility for the accuracy, completeness, or usefulness of any information, apparatus, product, or process disclosed, or represents that its use would not infringe privately owned rights. Reference herein to any specific commercial product, process, or service by trade name, trademark, manufacturer, or otherwise does not necessarily constitute or imply its endorsement, recommendation, or favoring by the United States Government or any agency thereof. The views and opinions of authors expressed herein do not necessarily state or reflect those of the United States Government or any agency thereof. 


\section{DISCLAIMER}

Portions of this document may be illegible in electronic image products. Images are produced from the best available original document. 


\section{(Guif \\ GULF GENERAL ATOMIC}

GA-10501

HTGR BASE PROGRAM

QUARTERLY PROGRESS REPORT

FOR THE PERIOD ENDING

FEBRUARY 28, 1971

This report was prepared as an account of work
sponsored by the United States Government. Neither
the United States nor the United States Atomic Energy
Commission, nor any of their employees, nor any of
their contractors, subcontractors, or their employees,
makes any warranty, express or implied, or assumes any
legal liability or responsibility for the accuracy, com-
plezeness or usefulness of any information. apparatus,
product or process disclused, or represents that its use
would not infringe privately owned rights.

Prepared under

Contract AT (04-3)-167

Project Agreement No. 17

for the

San Francisco Operations Office

U.S. Atomic Energy Commission 
GA-4072-December, 1962, through February, 1963 GA-4350-March, 1963, through May, 1963

GA-4569-June, 1963, through August, 1963

GA-4937-September, 1963, through November, 1963

GA-5104-December, 1963, through February, 1964

GA-5366-March, 1964, through May, 1964

GA-5618-June, 1964, through August, 1964

GA-5866-September, 1964, through November, 1964

GA-6113-December, 1964, through February, 1965

GA-6418-March, 1965, through May, 1965

GA-6671-June, 1965, through August, 1965

GA-6869-September, 1965, through November, 1965

GA-7010-December, 1965, through February, 1966

GA-7181-March, 1966, through May, 1966

GA-7396-June, 1966, through August, 1966

GA-7553-September, 1966, through November, 1966

GA-7801-December, 1966, through February, 1967

GA-7981-March, 1967, through May, 1967

GA-8200-June, 1967, through August, 1967

GA-8356-September, 1967, through November, 1967

GA-8530-December, 1967, through February, 1968

GA-8662-March, 1968, through May, 1968

GA-8860-June, 1968, through August, 1968

GA-9090-September, 1968, through November, 1968

GA-9227-December, 1968, through February, 1969

GA-9372-March, 1969, through May, 1969

GA-9660-June, 1969, through August, 1969

GA-9815-September, 1969, through November, 1969

GA-9944-December, 1969, through February, 1970

GA-10088-March, 1970, through May, 1970

GA-10288-June, 1970, through August, 1970

GA-10399-September, 1970, through November, 1970 


\begin{abstract}
This publication continues the quarterly report series on the HTGR Base Program study of the base technology leading to the development of a large High-temperature Gas-Cooled Reactor (HTGR) system. The development of the HTGR system will, in part, meet the greater National objective of more effective and efficient ultilization of our national resources. The development work reported here includes studies of basic fission-product distribution mechanisms, recycle fuel studies (including designing and testing of recycle test elements, development of a national recycle plan and of a recycle fuel plant, and exploration of head-end reprocessing methods), and physics and fuel management studies (including design and fabrication of fuel test elements, and physics tests performend in the HTLTR). Materials studies include irradiation and analysis of fuel particles in capsules to evaluate startup and recycle fuel systems, and basic studies of control materials and of carbon and graphite. Experimental procedures and results are discussed and, where appropriate, the data are presented in tables, graphs, and photographs. More detailed descriptions of experimental work are presented in topical reports, and these are listed at the end of the report for those concerned with the field.
\end{abstract}




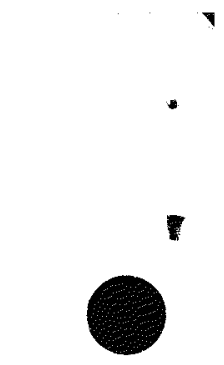

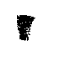
-
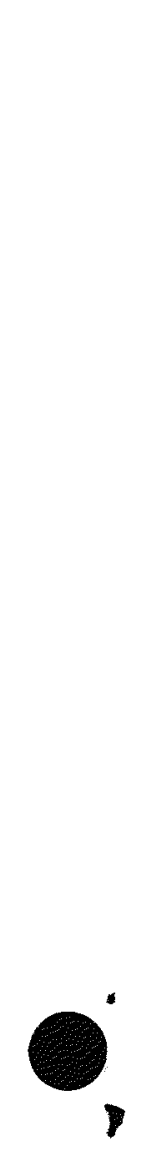


\section{INTRODUCTION}

This report covers the work performed by Gulf General Atomic under U.S. Atomic Energy Commission Contract AT (04-3)-167, Project Agreement No. 17. This Project Agreement calls for preliminary design and related exploratory development of a 1000-MW(e), gas-cooled, nuclear power reactor incorporating advanced technology. This program is based on the concept of the High-temperature Gas-Cooled Reactor (HTGR) system developed by GuIf General Atomic.

The related exploratory development effort is aimed at a 1000-MW(e) gas-cooled reactor plant that could be placed in operation in the 1970's, with operation of a 330-MW(e) prototype in the early 1970's. The plant would demonstrate such new design features as:

1. High conversion rates of fuel in a high-temperature, gas-cooled, thermal reactor using a Th-U ${ }^{233}$ fuel cycle.

2. Advanced reactor fuel elements, which may include new and simpler configurations and new methods of processing and fabricating to extend fuel lifetime and reduce fuel costs.

3. Alternative plant arrangements to reduce plant capital costs, including such possibilities as alternative materials (e.g., concrete pressure vessels) and the assembly of the reactor and steamgenerating equipment in a single containment.

Physics, metallurgical, chemical, electronic, and analytical design and development engineering programs support the primary reference design objective. 


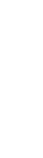


CONTENTS

ABSTRACT . . . . . . . . . . . . . . . . . . . . iii

INTRODUCTION . . . . . . . . . . . . . . . . . . V V

TASK IV. FISSION-PRODUCT MECHANISMS . . . . . . . . . . . 1

Strontium Deposition Loop . . . . . . . . . . . . . . 1

Vaporization of Cesium from Graphite. . . . . . . . . . . . 1

FIPER Code Development. . . . . . . . . . . . . . . . 3

Program Plan for Work to Establish Fission-product

Behavior. . . . . . . . . . . . . . . . . 4

Diffusion of Strontium in Graphite. . . . . . . . . . . . 4

Effect of Steam Oxidation on Graphite . . . . . . . . . . . . 5

TASK V. RECYCLE FUEL STUDIES. . . . . . . . . . . . . 6

Recycle Test Elements . . . . . . . . . . . . . . 6

Test Element Fabrication ................ 6

Test Element Irradiations. . . . . . . . . . . 6

HTGR Fuel Recycle Plant Study . . . . . . . . . . . . 6

National HTGR Recycle Development Program . . . . . . . . . 7

Head-end Processing. . . . . . . . . . . . . . . 7

Crushing and Tumbling.............. 8

Fluid-bed Burning. . . . . . . . . . . . . . 14

TASK VIII. PHYSICS AND FUEL MANAGEMENT. . . . . . . . . . . 26

Fuel Test Element . . . . . . . . . . . . . 26

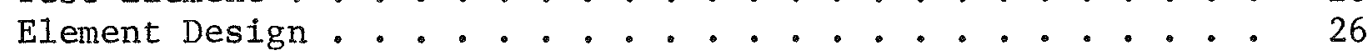

Element Fabrication. . . . . . . . . . . . 26

TASK IX. FUEL MATERIALS DEVELOPMENT . . . . . . . . . . . 27

Coated Particle Irradiations. . . . . . . . . . . . . 27

Capsule P13L . . . . . . . . . . . . . . . 27

Capsule P13M .................. 59

TASK XI. GRAPHITE RESEARCH. . . . . . . . . . . 64

Carbon Coating Irradiation. . . . . . . . . . . . . 64

Control Materials Irradiations. . . . . . . . . . . 65

Capsule BG-2............... 65

Boronated Graphite. . . . . . . . . . . . . . 75 
Dosimetry . . . . . . . . . . . . . . . . . . 75

B-10 Isotope Burnup . . . . . . . . . . . . . . 75

Thermal Conductivity. . . . . . . . . . . . . . . 80

Graphite Crysta11ite Dimensions . . . . . . . . . . . . 81

Appearance of Specimens . . . . . . . . . . . . . 81

Microstructure. . . . . . . . . . . . . . . . . 81

Hafnated Graphite. . . . . . . . . . . . . . . . . . . 84

Piggyback Specimens. . . . . . . . . . . . . . . . . . . 90

Boron Carbide ..................... . . 90

Boron Fibers. . . . . . . . . . . . . . . . . . . 99

Hafnium Carbide . . . . . . . . . . . . . . . 102

APPENDIX: PROJECT REPORTS PUBLISHED DURING THE QUARTER. . • . . . .107

\section{FIGURES}

5.1. Arrangement of 4-in. EXo burner after Run 99. . . . . . 15

5.2. Overal1 flowsheet of experiment F4B-104 . . . . . . . 17

5.3. Overa11 flowsheet of experiment F4B-107 . . . . . . . 18

5.4. Disposition of the components in material taken from the reactor in experiment F4B-104 . . . . . . . . . . 19

5.5. Disposition of the components in material taken from the reactor in experiment $\mathrm{F} 4 \mathrm{~B}-107$. . . . . . . . . 20

5.6. Disposition of heat lost from the fluid-bed burner. . . . . 22

9.1. Photographs of $\mathrm{UC}_{2}$ BISO-HTI coated particle batch 3516-47 • . 29

9.2. Photographs of $\mathrm{UC}_{2}$ BISO-LTI coated particle batch 4403-113. . 30

9.3. Photographs of $\mathrm{UC}_{2}$ TRISO-HTI coated particle batch 4413-5 . . 31

9.4. Photographs of $\mathrm{UO}_{2}$ TRISO-LTI coated particle batch 4413-67. . 32

9.5. Photographs of $(\mathrm{Th}, \mathrm{U}) \mathrm{C}_{2}$ TRISO-LTI coated particle batch

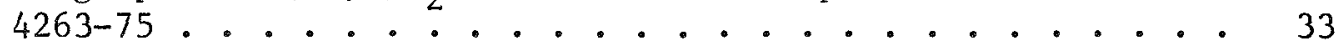

9.6. Photographs of $\mathrm{UO}_{2}$ BISO-LTI coated particle batch 4413-35 . 34

9.7. Photographs of $\mathrm{UC}_{2}$ TRISO-HTI coated particle batch 3516-39. . 35

9.8. Photographs of $\mathrm{UC}_{2}$ BISO-LTI coated particle batch 4403-113. • 36

9.9. Photographs of $\mathrm{UC}_{2}$ TRISO-LTI coated particle batch 4403-143.................. 37

9.10. Photographs of $\mathrm{UC}_{2}$ TRISO-HTI coated particle batch 3516-35. . 38

9.11. Photographs of $\mathrm{UC}_{2}$ TRISO-LTI coated particle batch 4413-7 • • 39

9.12. Photographs of $U_{2}$ TRISO-LTI coated particle batch 4413-21. - 40

9.13. Photographs of $\mathrm{UC}_{2}$ TRISO-HTI coated particle batch 3516-33. . 41

9.14. Photographs of $U_{2}$ BISO-LTI coated particle batch 4403-81 • 42 
9.15. Photographs of UC 2 TRISO-LTI coated particle batch 4413-5 . 43

9.16. Photographs of $\mathrm{UO}_{2}$ BISO-LTI coated particle batch 4413-35 • 44

9.17. Photographs of $\mathrm{UO}_{2}$ TRISO-LTI coated particle batch 4413-67. . 45

9.18. Photographs of $\mathrm{UC}_{2}$ BISO-HTI coated particle batch 3516-47 • . 46

9.19. Photographs of $\mathrm{UC}_{2}$ BISO-LTI coated particle batch 4403-145. . 47

9.20. Photographs of $\mathrm{UC}_{2}$ BISO-HTI coated particle batch 3516-57 . . 48

9.21. Photographs of $\mathrm{UC}_{2}$ BISO-ITI coated particle batch 4413-29. . 49

9.22. Photographs of $\mathrm{ThC}_{2}$ TRISO-LTI coated particle batch

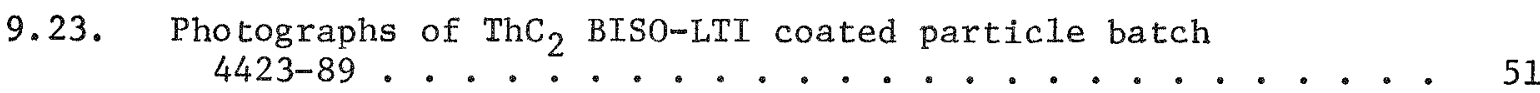

9.24. Photographs of $\mathrm{ThO}_{2}$ BISO-LTI coated particle batch 4413-75. . 52

9.25. Photographs of $\mathrm{UC}_{2}$ BISO-HTI coated particle batch 3516-47 • 53

9.26. Photographs of $\mathrm{UC}_{2}$ BISO-LTI coated particle batch 4403-113. . 54

9.27. Photographs of $\mathrm{UC}_{2}$ TRISO-LTI coated particle batch 4413-5 . . 55

9.28. Photographs of $(\mathrm{Th}, \mathrm{U}) \mathrm{C}_{2}$ TRISO-LTI coated particle batch

9.29. Photographs of $\mathrm{UO}_{2}$ TRISO-LTI coated particle batch 4413-67. . 57

9.30. Photographs of $\mathrm{UO}_{2}$ BISO-LTI coated particle batch 4413-35 . . 58

9.31. Capsule P13M layout showing five cells. . . . . . . . . . 61

11.1. Postirradiation density as a function of fast-neutron fluence at $900^{\circ}$ to $1000^{\circ} \mathrm{C}$ for LTI carbons $\left(36 \AA \geq \mathrm{L}_{\mathrm{C}}\right.$ $\geq 26 \AA$ ) for HTI carbon. .............. 66

11.2. Postirradiation density as a function of fast-neutron fluence at $600^{\circ}$ to $800^{\circ} \mathrm{C}$ for LTI carbons. . . . . . . 67

11.3. Effect of irradiation temperature on the high-fluence postirradiation density of LTI carbons. . . . . . . . 68

11.4. Dimensional change as a function of fast-neutron fluence at $900^{\circ}$ to $1000^{\circ} \mathrm{C}$ for LTI carbons . . . . . . . 69

11.5. Dimensional change as a function of fast-neutron fluence at $600^{\circ}$ to $800^{\circ} \mathrm{C}$ for LTI carbons. . . . . . . . 70

11.6. Postirradiation density as a function of preirradiation density of LTI carbon derived from different source gases and irradiated to $3.7 \times 10^{21} \mathrm{n} / \mathrm{cm}^{2}$ at $900^{\circ}$ to $650^{\circ} \mathrm{C} .$. .

11.7. Postirradiation density as a function of preirradiation density for as-deposited carbons annealed for $34 \mathrm{hr}$ at $1400^{\circ} \mathrm{C}$ and irradiated to $8.3 \times 10^{21} \mathrm{n} / \mathrm{cm}^{2}$ at $950^{\circ}$ to $800^{\circ} \mathrm{C}$. . . . . . . . . . . . . 
11.8. Postirradiation density as a function of preirradiation density for LTI carbons irradiated to $7.8 \times 10^{21} \mathrm{n} / \mathrm{cm}^{2}$

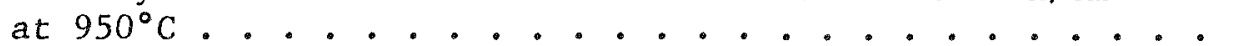

11.9. Dimensional change as a function of postirradiation density for LTI carbons irradiated to $7.8 \times 10^{21} \mathrm{n} / \mathrm{cm}^{2}$ at $950^{\circ} \mathrm{C}$. . . . . . . . . . . . 74

11.10. Thermal and fast-neutron exposure profile of capsule BG-2. . . 76

11.11. B-10 burnup profile for BG-2 specimens . . . . . . . . . 79

11.12. Warm-pressed boronated graphite (material 3685-124-2000, specimen 4-2-2) made with leached technical grade $\mathrm{B}_{4} \mathrm{C}$. . . 82

11.13. Warm-pressed boronated graphite (materia1 4465-24, specimen 3-5) control rod absorber material containing $0.69 \mathrm{~g}$ natural $\mathrm{B} / \mathrm{cm}^{3}$.............

11.14. Microstructure of boronated graphite (material 4465-24, specimen 4-4) made with $92 \%$ B-10-enriched boron powder irradiated in $\mathrm{BG}-2$ at $700^{\circ} \mathrm{C}$ to a fast-neutron exposure of 4.4 to $4.7 \times 10^{21} \mathrm{n} / \mathrm{cm}^{2}(\mathrm{E}>0.18 \mathrm{Mev})$........

11.15. Microstructure of boronated graphite (material 4465-26, specimen 4-7) made with B-10-enriched $\mathrm{B}_{4} \mathrm{C}$. . . . . . . 86

11.16. Microstructure of boronated graphite (material 4465-26, specimen 4-7) made with B-10-enriched $\mathrm{B}_{4} \mathrm{C} . . . . . . .$.

11.17. Cylindrical specimen of hafnated graphite, HfC + graphite (material 4065-132-2600), before irradiation in capsule BG-2 . . . . . . . . . . . . . .

11.18. Microstructure of hafnated graphite material 4065-132-2000 . .

11.19. Boron carbide (high boron, 76 wt-\% B, marerial 4065-84, specimen 1-6). . . . . . . . . . . . . . . .

11.20. Boron carbide (technical grade, $70 \mathrm{wt}-\%$ B, material 3685-84, specimen 3-4). . . . . . . . . . . . . . 93

11.21. Spherical $\mathrm{B}_{4} \mathrm{C}$ granules (material 3685-4, specimen 11F) . . . 94

11.22. Boron carbide (material 4465-7, specimen 33F) made from B-10 enriched boron $(B-10 / B-11=11.5) . . . . . .995$

11.23. Boron carbide (material 3685-105, specimen 31F) made from B-10 depleted boron $(B-10 / B-11=0.015)$. . . . . . 96

11.24. B-10 burnout profile for $B_{4} C$ piggyback samples in capsule $\mathrm{BG}-2$....................

11.25. Effect of $\mathrm{B}-10$ fission density on the density of $\mathrm{B}_{4} \mathrm{C}$ irradiated in piggyback location of BG-2 . . . . . . . . 100

11.26. Boron filament (material 3471-122, specimen 23s) 0.004-in.diameter vapor-deposited boron on 0.0005-in.-diameter tungsten wire. . . . . . . . . . . . . . . . . 
11.27. Hafnium carbide (4065-111, specimen 2-1-S) . . . . . . . 103

11.28. Metallographic cross section of hafnium carbide granules (4065-111, specimen 2-7) in an opened piggyback crucible from capsule BG-2. . . . . . . . . . . . 104

11.29. Microstructure of hafnium carbide (4065-111, specimen 2-1-S) irradiated in capsule BG-2 piggyback location at $550 \pm 50^{\circ} \mathrm{C}$ to a fast-neutron exposure of $5.5 \times 10^{21}$

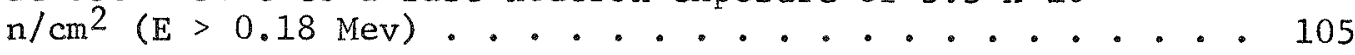

\section{TABLES}

5.1. Crushing, Tumbling, and Screening Separation of Graphite From Fuel Particles.............. 9 9

5.2. Comminution of 2-in.-diameter Pitch-bonded Fuel Rods . . . . 11

5.3. Screen Analysis After Hammermilling. . . . . . . . . . 12

5.4. Comminution of Fuel Elements . . . . . . . . . . . . 13

5.5. Results of Burning Crushed TRISO/TRISO Pitch-bonded Rods and Graphite. . . . . . . . . . . . . . . 16

5.6. Results of Batch Experiments Done in the 4-in. ENDO Burner . . 24

9.1. Summary Description of the Coated Particle Samples Tested in Capsule P13L . . . . . . . . . . . . 28

9.2. Details of Fuel Rods Irradiated in Capsule P13M. . . . . . . 62

9.3. Properties of Coated Particles Irradiated in Capsule P13M. . . 63

11.1. Summary of Material Properties and Irradiation Effects in Boronated Graphite in the BG-2 Experiment Including

Prior Irradiation in the BG-1 Experiment . . . . . . . . 77

11.2. Heat Capacity of Graphite, Boron Carbide, and Boronated Graphites. . . . . . . . . . . . . . 80

11.3. Piggyback Samples Irradiated in Capsule BG-2 . . . . . . . . 91

11.4. Summary of BG-2 Piggyback Specimen Results . . . . . . . . 98

11.5. Spectrographic Analysis of Hafnium Carbide . . . . . . . . 106 
TASK IV

FISSION-PRODUCT MECHANISMS

STRONTIUM DEPOSITION LOOP

A simple strontium deposition loop is being assembled to study the nature, distribution, and adherence of strontium deposits formed under typical reactor conditions. A diagram of the strontium deposition loop is given in the previous quarterly report (GA-10399).

At present al1 phases of construction on the loop hardware are in progress and all purchase orders to date have been completed. Most components are being returned unassembled or partially assembled for final fitting and examination prior to completion of welding and leak check operations. On hand for this purpose are the source chamber and blower housing. Nearing this stage of completion are the motor housing, motor extension shaft, and loop tubing. Completed are the source crucibles and source chamber heater.

A blower motor control and monitoring instrument has been designed and is currently being completed and calibrated. This unit is intended to continually monitor and record the blower motor current and that provide some measure of remote protection from overload failure in the motor.

VAPORIZATION OF CESIUM FROM GRAPHITE

In preparation for a mass spectrometric study of the vaporization behavior of strontium and cesium cosorbed on H-327 graphite, mass spectrometric measurements of adsorption isotherms of cesium on $\mathrm{H}-327$ graphite are being carried out. The purpose of these measurements is to determine the correspondence between cesium vapor pressure data measured using the mass spectrometer and data measured using the pseudoisopiestic method. 
Extensive cesium vapor pressure measurements have been previously performed using the pseudoisopiestic method and were described in an earlier quarterly report (GA-8662). As described in the previous quarterly report (GA-10399), data obtained by the two methods are somewhat different, and the reason for this difference has not yet been resolved. However, vaporization experiments were performed to look at the possibility of interaction between cesium and the molybdenum Knudsen cell having affected the sorption isotherms.

Each experiment was carried out as for a normal isotherm measurement, but was stopped before all the cesium had been vaporized from the cell. Each cell contained two small pieces of molybdenum foil to enable measurement of the amount of cesium sorbed on the molybdenum. Two different impregnated samples were run. The initial/final cesium concentrations were $1.7 / 1.0 \mathrm{mg} / \mathrm{g}$ graphite and $1.1 / 0.04 \mathrm{mg} / \mathrm{g}$ graphite.

For the first experiment, chemical analysis of one of the foil tabs gave only an upper limit, due to the small amount of sorbed cesium. Using that value and correcting for the total molybdenum surface area (cell plus foil), it was found that less than $1 \%$ of the total cesium in the cell had been associated with the molybdenum when the experiment was interrupted. The balance was sorbed on the graphite. After the sample was emptied from the cell, the cell was replaced in the mass spectrometer and reheated. The amount of cesium that vaporized from the cell, including the other foil tab, could be calculated from the mass spectrometer sensitivity. Assuming all the sorbed cesium could be vaporized, an estimate similar to that made above was obtained for the amount of cesium that had been associated with the cell plus foil.

For the second experiment, a similar vaporization was carried out for the emptied cell. A smaller absolute amount of cesium could be vaporized, but the amount was again of the order of $1 \%$ of the amount of cesium that still remained sorbed on the graphite. No attempt was made to chemically analyze the foil tabs. 
These results indicate that the measured sorption isotherms of cesium on graphite have not been affected by cell interactions.

\section{FIPER CODE DEVELOPMENT}

The purpose of the FIPER II Code is the calculation of concentration profiles and release currents of metallic fission products in two-dimensional geometries. The code consists of the MASTER code, which contains computational routines that are problem-independent, and the AUXILIARY code, which is composed of the routines that are strongly dependent on the physical and chemical problem statement.

Recent work has concentrated on the AUXILIARY code. It has been developed into a form that uses explicit, flexible, and easily understandable statements for the following mathematical relations and physical quantities:

1. General boundary and interface conditions for current and concentrations. For example, a boundary situation can be considered where both current and concentrations are finite.

2. An initial concentration profile in terms of a function that is smooth even in the vicinity of a corner.

3. Diffusion parameters in terms of a function that allows for smooth changes in the vicinity of a corner.

4. Distribution coefficients at each mesh point.

Points 1 and 4 are, for example, important in an experimental situation where the diffusion takes place along the structural defects of a material, such as nuclear graphite, that is permeated by pores. Permeation in pores is important in considering the release of both gaseous and metallic fission products. 
The connection between the outer surface (say, the surface of a fuel hole) and the inner surface of a pore forms a corner. The physical parameters for outer and inner surfaces are the same (diffusion coefficients, distribution ratios, etc.). The aim is therefore to describe the physical and chemical parameters near a corner by reasonably smooth functions (see the previous quarterly report, GA-10399).

PROGRAM PLAN FOR WORK TO ESTABLISH FISSION-PRODUCT BEHAVIOR

The updating of the National Program Plan for Work to Establish Fissionproduct Behavior in HTGR Systems has been completed. The purpose of this document is to present (1) an overall discussion of the technical aspects of fission-product behavior in HTGR systems and (2) an overall program for further development work to characterize fission-product behavior in HTGR systems. The first edition was completed in June 1969.

In updating the document, is was expanded considerably to include a more thorough and comprehenseive discussion of known information and sources of information related to all aspects of fission-product behavior in HTGR systems. The document also describes needed information on fission-product behavior and outlines a program of work for obtaining the needed information.

DIFFUSION OF STRONTIUM IN GRAPHITE

Strontium permeation experiments 4370-143 and 4370-144 with initial source concentrations of $20.3 \mathrm{mg} \mathrm{Sr} / \mathrm{g}$ matrix (source) material have now accumulated $3700 \mathrm{hr}$ at $850^{\circ} \mathrm{C}$ and $4400 \mathrm{hr}$ at $1000^{\circ} \mathrm{C}$, respectively. Preliminary data for these experjments are given in earlier quarterly report GA-9944, and a description of the apparatus is given in earlie quarterly report GA-9660. The release rates have decreased from $1 \times 10^{-8}$ and $5 \times 10^{-8}$ $\mathrm{mg} \mathrm{Sr} / \mathrm{hr}$ to approximately zero during the last $800 \mathrm{hr}$. It is not understood why this has happened. However, the specific activity of the $\mathrm{Sr}-85$ decreases with a 65-day half life, and the same source has been in the system for approximately 1 year. Therefore, small releases can not be measured due to 
the lack of activity. A change of the source (increase of the specific activity) is being considered to be able to count small release values. Fractional releases are very low (around $10^{-5}$ ); therefore, depletion of the source material would not account for the decrease in release rates.

The primary objective of these experiments is to measure the temperature dependence of permation coefficients. Another objective is to continue the experiments for a sufficient length of time to be assured that steady state has been reached. This will make it possible to determine whether diffusion in the bulk graphite becomes important after some long time period. Earlier results suggested that diffusion in paths of high diffusivity (pores) is predominant at all times over diffusion in the bulk graphite (see earlier quarterly report GA-9815).

EFFECT OF STEAM OXIDATION ON GRAPHITE

Studies on the effect of steam oxidation on the strength of $\mathrm{H}-327$ graphite are continuing. Tensile specimens of two different dimensions (1/2 in. in diameter by $1-1 / 2 \mathrm{in.}$ long and $1 / 2 \mathrm{in.}$ in diameter by $3 \mathrm{in}$. long) have been exposed to $3 \%$ steam in helium at $900^{\circ} \mathrm{C}$. Specimens have been oxidized to approximately $3 \%$ and $7 \%$ burnoff using $3 \%$ steam in helium.

Specimens are being oxidized to about 15\% burnoff. Since this degree of burnoff would require several months at the $3 \%$ steam condition, the moisture content has been increased to about $25 \%$ in order to attain the desired burnoff in a reasonable length of time.

The tensile strength of the oxidized specimens is being measured. 
TASK V

RECYCLE FUEL STUDIES

RECYCLE TEST ELEMENTS

Test Element Fabrication

Fuel particles are now complete for the final recycle test element, and fuel rods are in production. The loading in fuel body Nos. 5 and 6

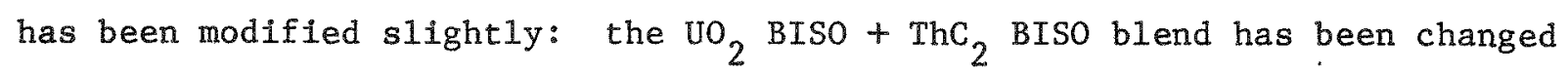
to $\mathrm{UO}_{2}$ TRISO $+\mathrm{ThO}_{2} \mathrm{BISO}$. The new blend represents one of the alternative 1100-MW(e) fue1 designs.

\section{Test Element Irradiations}

The six recycle test elements have accumulated 168 EFPD as of January 15, 1971. Total burnups for the elements as of January 13, 1971, are given below:

\begin{tabular}{l|c|c|c}
\hline Element & $\begin{array}{c}\text { Burnup } \\
\text { (\% FTMA) }\end{array}$ & Element & $\begin{array}{c}\text { Burnup } \\
\text { (\% FTMA) }\end{array}$ \\
\hline RTE-2 & 1.97 & RTE-6 & 2.14 \\
RTE-4 & 1.66 & RTE-7 & 1.58 \\
RTE-5 & 1.77 & RTE-8 & 2.04 \\
\hline
\end{tabular}

HTGR FUEL RECYCLE PLANT STUDY

Process evaluation work on the combined reprocessing-refabrication plant study for facilities of three different sizes has been centered on the head-end 
steps of the reprocessing section. In particular, the unit operations of size reduction and fuel-graphite separation at the initial block crushing steps are being investigated. There is a strong incentive to effect a fue1graphite separation as early in the processing as possible to avoid the possibility of $\mathrm{UO}_{2}$ snuffing out the bulk graphite burning and to simplify offgas handling problems. Unit operations work in size reduction indicates that several stages of crushing in series are required to reduce the graphite material for fuel particle separation and to obtain an adequate size for feed to the fluid-bed burners. The engineering evaluation effort is being directed toward an optimization of several size reduction methods in terms of fuel-graphite separation and the number of unit operations required.

NATIONAL, HTGR RECYCLE DEVELOPMENT PROGRAM

A revised draft of the National HTGR Recycle Development Program Plan was received from Oak Ridge National Laboratory and was reviewed. On January 13 a meeting was held with GGA, AEC, and ORNL representatives to review the program plan. Based on the review and meeting presentations, the overall program was found to be satisfactory.

HEAD-END PROCESSING

Emphasis in the crushing and screening experiments is currently being directed toward achieving a good separation of particle-free graphite. Two approaches appear encouraging: (1) horizontal crushing in a jaw crusher and (2) splitting the fuel element with tapered bars. Results obtained from pressing the fuel rods out with a punch indicate that this method does not appear feasible, and it is not being pursued.

The combustion of crushed TRISO/TRISO and TRISO/BISO pitch-bonded rods appears to be relatively trouble-free, but the combustion of BISO/BISO still needs to be proved.

The first few experiments on the 4-in. ENDO burner have been very successful. Ground TRISO particles have been burned without trouble in the 
presence of an inert fluidizing medium. Combusion of crushed graphite in the 8-in. burner presents no problems. A 9.5-hr run was completed with a low burning rate of about $90 \mathrm{~g} / \mathrm{min}$. The ultimate objective of burning at a rate of $250 \mathrm{~g} / \mathrm{min}$ has yet to be attained.

\section{Crushing and Tumbling}

Various experiments were carried out to achieve an efficient separation of graphite from fuel rods (see Table 5.1). In the experiments in which a crush operation was performed, the material was fed to the jaw crusher with the fuel rods in the vertical position. This method resulted in a fairly high fraction of small-size graphite that accompanied the crushed fuel rods. In order to avoid repeatedly crushing material that had already been reduced to $3 / 16$ in., the crushed product was screened after each step. This led to a fairly large number of crushing and screening operations, but it achieved up to $70 \%$ separation of the burnable carbon with less than $5 \%$ particle breakage.

Run 18 was carried out to determine whether the number of steps could be reduced by using a larger screen; the result was encouraging, with a graphite separation of $58.4 \%$ 。

Runs 20 through 27 used a variation of the procedure in which the material was fed to the crusher with the fuel rods in the horizontal position. This broke the graphite along the webs and created less graphite fines. The amount of separated burnable carbon shows that horizontal feeding produced an immediate improvement, and this variation is being followed by further detailed work. Because of the scarcity of expendable fuel rods (depleted U), concrete rods of about the same strength as real fuel rods are being substituted in these tests.

Run 19 was carried out to determine whether it was possible to press the fuel rods out of the fuel holes. The rods were coated with a slurry of borax in alcohol and inserted into the fuel holes of a 12-rod block without plugs. The fuel element was then heated to $1000^{\circ} \mathrm{C}$ to carbonize the rods, and melt 
TABLE 5.1

CRUSHING, TUMBLING, AND SCREENING SEPARATION OF GRAPHITE FROM FUEL PARTICLES

\begin{tabular}{|c|c|c|c|c|c|c|c|}
\hline \multirow{2}{*}{$\begin{array}{l}\text { Exp. } \\
\text { No. }\end{array}$} & \multicolumn{4}{|c|}{ Operation $^{(a)}$} & \multirow{2}{*}{$\begin{array}{c}\text { Separated } \\
\text { Burnable } \\
\text { Carbon }(\%)\end{array}$} & \multirow{2}{*}{$\begin{array}{l}\text { Broken } \\
\text { Particles } \\
(\%)\end{array}$} & \multirow{2}{*}{$\begin{array}{l}\text { Type } \\
\text { of } \\
\text { Feed (b) }\end{array}$} \\
\hline & 1 & 2 & 3 & 4 & & & \\
\hline 2 & $\begin{array}{l}\text { Crush } 3 / 4 \\
\text { Screen } 3 / 16\end{array}$ & $\begin{array}{l}\text { Crush } 1 / 2 \\
\text { Screen } 3 / 16\end{array}$ & Crush 5/32 & $-\infty$ & 0 & 4.6 & A \\
\hline 3 & $\begin{array}{l}\text { Crush } 1 \\
\quad \text { Screen } 3 / 16\end{array}$ & $\begin{array}{l}\text { Crush } 0.475 \\
\text { Screen } 3 / 16\end{array}$ & Tumble $1 / 4$ & $-\infty$ & 54.4 & 1.8 & A \\
\hline 4 & $\begin{array}{l}\text { Crush } 1-1 / 2 \\
\text { Screen } 3 / 16\end{array}$ & $\begin{array}{l}\text { Crush } 0.475 \\
\text { Screen } 3 / 16\end{array}$ & Tumb le $1 / 4$ & --- & 54.1 & 1.9 & A \\
\hline 5 & $\begin{array}{l}\text { Crush } 3 / 4 \\
\text { Screen } 3 / 16\end{array}$ & $\begin{array}{l}\text { Tumble } 1 / 2 \\
\text { Screen } 3 / 16\end{array}$ & Tumble $1 / 4$ & - & 69.3 & $>4.4$ & A \\
\hline 6 & $\begin{array}{l}\text { Crush } 3 / 4 \\
\text { Screen } 3 / 16\end{array}$ & $\begin{array}{l}\text { Tumble } 1 / 2 \\
\text { Screen } 3 / 16\end{array}$ & $\begin{array}{l}\text { Crush } 9 / 32 \\
\text { Screen } 3 / 16\end{array}$ & Tumble $1 / 4$ & 63.2 & 3.0 & A \\
\hline 7 & $\begin{array}{l}\text { Crush } 3 / 4 \\
\quad \text { Screen } 3 / 16\end{array}$ & $\begin{array}{l}\text { Crush } 17 / 64 \\
\text { Screen } 3 / 16\end{array}$ & Tumble $1 / 4$ & -- & 30.9 & 3.8 & B \\
\hline 15 & $\begin{array}{l}\text { Crush } 7 / 16 \\
\text { Screen } 3 / 16\end{array}$ & Tumb le $3 / 8$ & $\begin{array}{l}\text { Cone Crush } \\
5 / 32\end{array}$ & $-\infty$ & 40.0 & -- & A \\
\hline 18 & $\begin{array}{l}\text { Crush } 3 / 4 \\
\text { Screen } 5 / 8\end{array}$ & $-\infty$ & -- & -- & 58.4 & - & A \\
\hline 19 & $\begin{array}{l}\text { Press fuel } \\
\text { rod }\end{array}$ & (Block split) & $-\infty$ & -- & - & - & A \\
\hline 20 & $\begin{array}{l}\text { Horizontal } \\
\text { Crush } 3 / 4 \\
\text { Screen } 5 / 8\end{array}$ & -- & $-\infty$ & $-\infty$ & 73.6 & -- & $\mathrm{D}$ \\
\hline 21 & $\begin{array}{l}\text { Horizontal } \\
\text { Crush } 3 / 4 \\
\text { Screen } 5 / 8\end{array}$ & -- & $-\infty$ & -- & 79.5 & -- & $\mathrm{D}$ \\
\hline 23 & $\begin{array}{l}\text { Horizontal } \\
\text { Crush } 3 / 4 \\
\text { Screen } 5 / 8\end{array}$ & -- & $-m-$ & $-\infty$ & 75.3 & -- & E \\
\hline 24 & $\begin{array}{l}\text { Horizontal } \\
\text { Crush } 3 / 4 \\
\text { Screen } 5 / 8\end{array}$ & -- & $--m$ & -- & 81.2 & - & $F$ \\
\hline 25 & $\begin{array}{l}\text { Horizontal } \\
\text { Crush } 3 / 4 \\
\text { Screen } 5 / 8\end{array}$ & $--\infty$ & -- & $-m$ & 70.3 & - & D \\
\hline 26 & $\begin{array}{l}\text { Horizontal } \\
\text { Crush } 3 / 4 \\
\text { Screen } 5 / 8\end{array}$ & -- & $--\infty$ & -- & 67.9 & -- & F \\
\hline 27 & $\begin{array}{l}\text { Horizontal } \\
\text { Crush } 3 / 4 \\
\text { Screen } 5 / 8\end{array}$ & $--\infty$ & $-\infty$ & $-\infty$ & $\sim 65.0$ & -- & G \\
\hline
\end{tabular}

(a) Crush and screen gizes are in inches.

(b) Feed types are as follows:

$A=$ Rezolin-bonded, 12 -rod fuel element.

$B=$ Pitch-bonded TRISO/BISO, 2 in. diameter, graphite added.

$D=51 \mathrm{n},-10 \mathrm{ng} 12$-rod fuel element.

$E=5$ in.-long 12-rod block loaded with 5-in. graphite rods.

$F=5$ in.-1ong 12-rod block loaded with 2 -1n. graphite rods.

$G=5$ in.-1ong 12-rod block loaded with concrete rods. 
the borax to form a good bond between the rods and the block. A punch was mounted in position against the end of a visible fuel rod and pressure applied, but within 1 in. of travel the fuel rod sheared and a chunk of graphite broke off the side of the block. As a result it was decided to abandon this approach.

Another method of fuel element breaking is to split the block by pushing tapered bars down the coolant holes. This has been tried on a 12-rod fuel element with some success. The graphite broke into pieces about 2 in. square and $3 / 4$ in. thick, and tumbling and screening then separated about $70 \%$ of the burnable carbon from the fuel stream. Further work on this system is planned.

When a fuel element has been crushed and divided into graphite and particles, the particle stream must be comminuted to $-3 / 16$ in. so that it can be bed to a fluid bed turner. The results of various approaches to this step are presented in Table 5.2. Hammer-milling apparently requires the least number of operations, and a sieve analysis of the product, which requires no further processing to make it suitable for fluid-bed feed, is given in Table 5.3. Jaw crushing, screening, and cone crushing also produce the desired product, but take too 1ong. The operation of the cone crusher, which resulted in an acceptably low fraction of broken particles, might be as effective as a hammermill, but the scale of the equipment available made a valid comparison impossible.

Further work may show that graphite-particle separation is not necessary, in which case the fuel element can be crushed and comminuted for feed to one type of burner. Results obtained after crushing and screening (see Table 5.4), show acceptably low particle breakage. However, the steps are numerous, and it would be advantageous to use a single step such as that obtained with the hammermill (see Table 5.2). To test this approach, two 12-rod fuel elements have been sent to ORNL for hammermilling.

Some experiments had been planned that involve crushing the fuel elements and feeding the lumps to a modified fluid-bed burner. This approach would be 
TABLE 5.2

COMMINUTION OF 2-IN.-DIAMETER PITCH-BONDED FUEL RODS

\begin{tabular}{|c|c|c|c|c|c|c|}
\hline \multirow{2}{*}{$\begin{array}{l}\text { Exp. } \\
\text { No. }\end{array}$} & \multicolumn{5}{|c|}{ Operation (a) } & \multirow{2}{*}{$\begin{array}{c}\text { Broken } \\
\text { Particles } \\
(\%)\end{array}$} \\
\hline & 1 & 2 & 3 & 4 & 5 & \\
\hline 8 & $\begin{array}{l}\text { Crush } 3 / 4 \\
\text { Screen } 3 / 16\end{array}$ & Crush $17 / 64$ & Tumble $1 / 4$ & -- & --- & 1.3 \\
\hline 9 & $\begin{array}{l}\text { Crush } 3 / 4 \text { in. } \\
\text { Screen } 3 / 16\end{array}$ & $\begin{array}{l}\text { Crush } 17 / 64 \\
\text { Screen } 3 / 16\end{array}$ & $\begin{array}{l}\text { Crush } 17 / 64 \\
\text { Screen } 3 / 16\end{array}$ & $\begin{array}{l}\text { Cone crush } \\
3 / 16\end{array}$ & $\begin{array}{l}\text { Cone crush } \\
1 / 8\end{array}$ & -- \\
\hline 12 & $\begin{array}{l}\text { Crush } 3 / 4 \\
\quad \text { Screen } 3 / 16\end{array}$ & $\begin{array}{l}\text { Crush } 7 / 16 \\
\text { Screen } 3 / 16\end{array}$ & $\begin{array}{l}\text { Cone crush } \\
5 / 32\end{array}$ & $\cdots$ & --- & 2.3 \\
\hline 16 & $\begin{array}{l}\text { Hammermil1 (b) } \\
3 / 4\end{array}$ & -- & -- & -- & -- & 3.2 \\
\hline 17 & $\begin{array}{l}\text { Hammermi } 11 \\
3 / 8\end{array}$ & -- & -- & -- & --- & 0.5 \\
\hline
\end{tabular}

(a) Crush and screen sizes are in inches.

(b) Rod sent to ORNL for crushing. 
TABLE 5.3

SCREEN ANALYSIS AFTER HAMMERMILLING

\begin{tabular}{l|c|r}
\hline \multirow{2}{*}{$\begin{array}{c}\text { Screen } \\
\text { Size } \\
\text { (in.) }\end{array}$} & \multicolumn{2}{|c}{ Fraction (\%) } \\
\cline { 2 - 3 }+0.185 & Run 16 & Run 17 \\
+0.111 & 9.44 & 1.34 \\
+0.0787 & 9.35 & 3.87 \\
+0.0278 & 5.23 & 3.92 \\
+0.0165 & 16.75 & 17.98 \\
+0.0097 & 51.27 & 63.37 \\
-0.0097 & 2.89 & 3.28 \\
\hline
\end{tabular}


TABLE 5.4

COMMINUTION OF FUEL ELEMENTS

\begin{tabular}{|c|c|c|c|c|c|c|}
\hline \multirow{2}{*}{$\begin{array}{l}\text { Exp. } \\
\text { No. }\end{array}$} & \multicolumn{4}{|c|}{ Operation (a) } & \multirow{2}{*}{$\begin{array}{c}\text { Broken } \\
\text { Particles } \\
(\%)\end{array}$} & \multirow{2}{*}{$\begin{array}{c}\text { Type } \\
\text { of } \\
\text { Feed (b) }\end{array}$} \\
\hline & 1 & 2 & 3 & 4 & & \\
\hline 2 & $\begin{array}{l}\text { Crush } 3 / 4 \\
\text { Screen } 3 / 16\end{array}$ & $\begin{array}{l}\text { Crush } 1 / 2 \\
\text { Screen } 3 / 16\end{array}$ & $-\infty-\infty$ & $-\infty$ & 4.6 & $\mathbf{A}$ \\
\hline 10 & $\begin{array}{l}\text { Crush } 3 / 4 \\
\text { Screen } 3 / 16\end{array}$ & $\begin{array}{l}\text { Crush } 17 / 64 \\
\text { Screen } 3 / 16\end{array}$ & $\begin{array}{l}\text { Cone crush } \\
3 / 16\end{array}$ & $\begin{array}{l}\text { Cone crush } \\
1 / 8\end{array}$ & 4.3 & $\mathrm{~B}$ \\
\hline 11 & $\begin{array}{l}\text { Crush } 3 / 4 \\
\text { Screen } 3 / 16\end{array}$ & $\begin{array}{l}\text { Crush } 17 / 64 \\
\text { Screen } 3 / 16\end{array}$ & $\begin{array}{l}\text { Cone crush } \\
5 / 32\end{array}$ & --- & 3.7 & $B$ \\
\hline
\end{tabular}

(a) Crush and screen sizes are in inches.

(b) Feed types are as follows:

$A=$ Rezolin-bonded, 12-rod fuel element.

$B=$ Pitch-bonded TRISO/BISO, 2 in.-diameter, graphite added. 
considered if the broken particle fraction was unacceptably high when the comminuting methods mentioned above are used. As can be seen, the broken particle fraction remains acceptably low under all the comminuting conditions tested, and therefore, the lump-feed approach will not be experimented with at the present time.

Fluid-Bed Burning

4-in. EXO Fluid Bed Burner. Operation of the 4-in. EXo burner was continued, with Runs 96 and 97 being checks of equipment after some minor modifications.

Runs 98 and 99 were to determine the ease of operation when crushed TRISO/TRISO rods and graphite are fed; the results are given in Table 5.5. Both experiments ran smoothly and were trouble-free, and there appears to be little difference between top or bottom feed. The carbon concentration in the product is higher than expected, but this is of no consequence because both fissile and fertile particles will be ground and burned in the ENDO burner after screening. The fraction of broken particles in Run 98 was higher than has been previously experienced. It appears unlikely that this increase is due to bottom feeding in contrast with the low breakage experienced with top feeding, but further work will elucidate this point. The offgas oxygen concentration in both runs was usually zero, but infrequently rose to the stated value. It was concluded from these runs that there is no difficulty in feeding and burning TRISO/TRISO pitch-bonded rods crushed to $-3 / 16$-in. screen size.

The reactor was modified by installing two sintered stainless steel filters in the deentrainment section. The pore size was $35 \mu \mathrm{m}$, and each filter was automatically blown back every minute in turn. The modified reactor is shown in Fig. 5.1. 


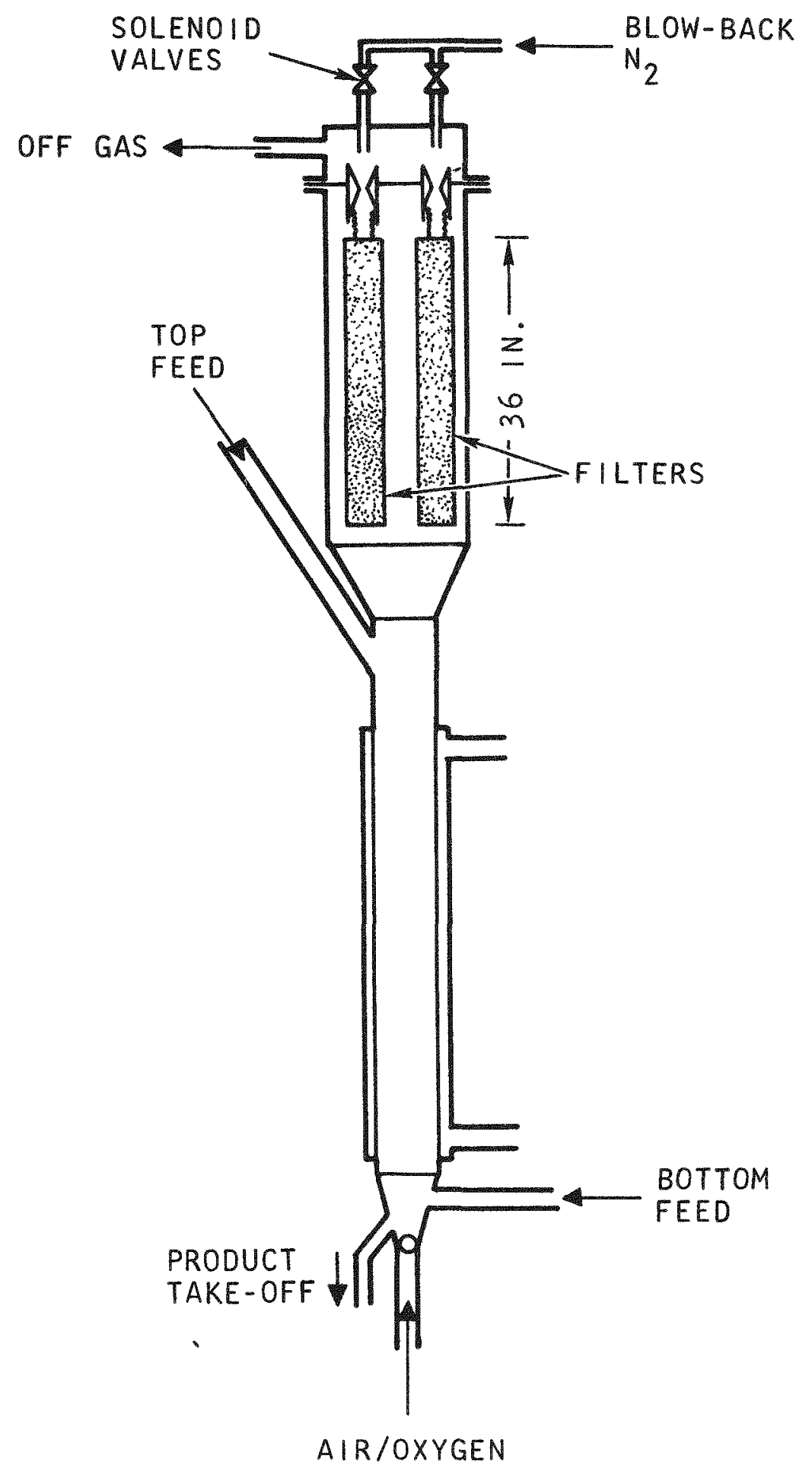

Fig. 5.1. Arrangement of 4-in. EXo burner after Run 99 
TABLE 5.5

RESULTS OF BURNING CRUSHED TRISO/TRISO

PITCH-BONDED RODS AND GRAPHITE

\begin{tabular}{l|c|c} 
& $\begin{array}{c}\text { Run } \\
98\end{array}$ & $\begin{array}{l}\text { Run } \\
99\end{array}$ \\
\hline Feed weight (-3/16 in.), Kg & 13.758 & 6.719 \\
Feed position, top or bottom & $\begin{array}{l}\text { Bottom } \\
\text { Top }\end{array}$ & 811 \\
Duration of run, min & 4.286 & 4.185 \\
Product weight, Kg & 30.5 & 29.1 \\
Rate of burning, avg, g c/min. & 9.8 & 7.4 \\
Fraction carbon in product, $\%$ & 11.2 & 0.45 \\
Fraction broken particles (fissile \& fertile), \% & $<3$ & $<3.5$ \\
O, concentration in offgas, \% & & \\
\hline
\end{tabular}

Runs 104 and 107 were carried out to determine the ease of operation when crushed TRISO/BISO pitch-bonded rods and graphite are fed. The flow sheets of the two experiments are shown on Figs. 5.2 and 5.3, respectively. The product, continuously taken off, was screened through a $420-\mu \mathrm{m}$ mesh in batches and the $+420 \mu \mathrm{m}$ returned to the reactor. The $-420 \mu \mathrm{m}$ material was collected for burning in the ENDO burner. This method of operation ensured that all the unburned BISO particles $(+420)$ were returned to the reactor, and that fissile particles, Tho ${ }_{2}$, and carbon fines were removed. Previous experience has shown that as the fines concentration in the fluid beds exceeds a critical value (about $30 \%$ ) combustion cannot be maintained. The disposition of the components in the material taken from the reactor in each experiment is shown in Figs. 5.4 and 5.5. The interesting features about these two runs are as follows:

1. The fraction of broken fissile particles must be fairly small, because the expected recovery was less than actual in both runs. In addition, the quantity of $\mathrm{SiC}$ shells accompanying the $\mathrm{ThO}_{2}$ was negligible.

2. It appears that the combustion of $25 \%$ TRISO/75\% BISO is as troublefree as $40 \%$ TRISO/60\% BISO feed. 


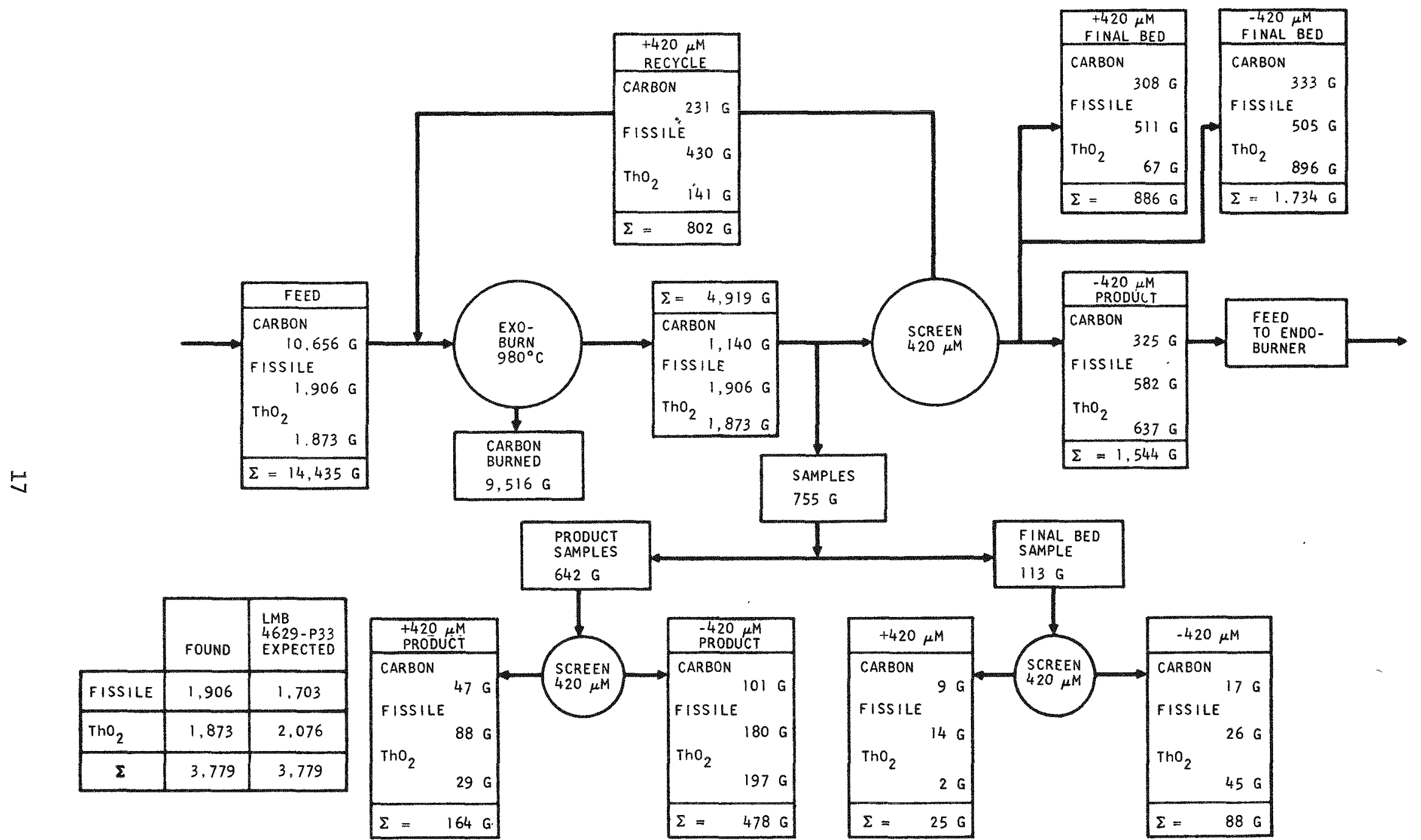

Fig. 5.2. Overall flowsheet of experiment F4B-104; duration 292 min; feed consisted of $40 \%$ TRISO and $60 \%$ BISO fuel particles 


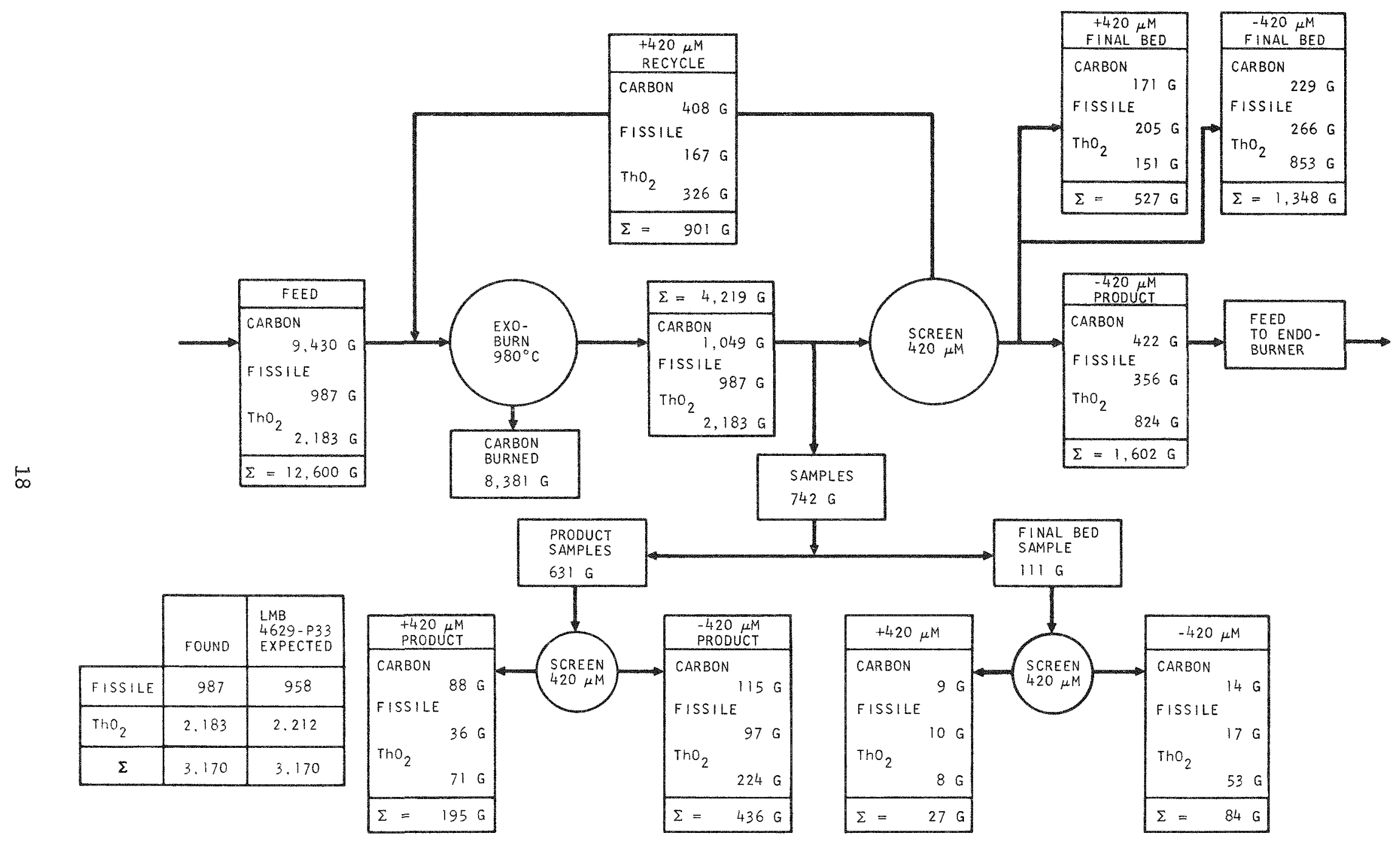

Fig. 5.3. Overall flowsheet of experiment F4B-107; duration $326 \mathrm{~min}$; feed consisted of $25 \%$ TRISO and $75 \%$ BISO fuel particles 


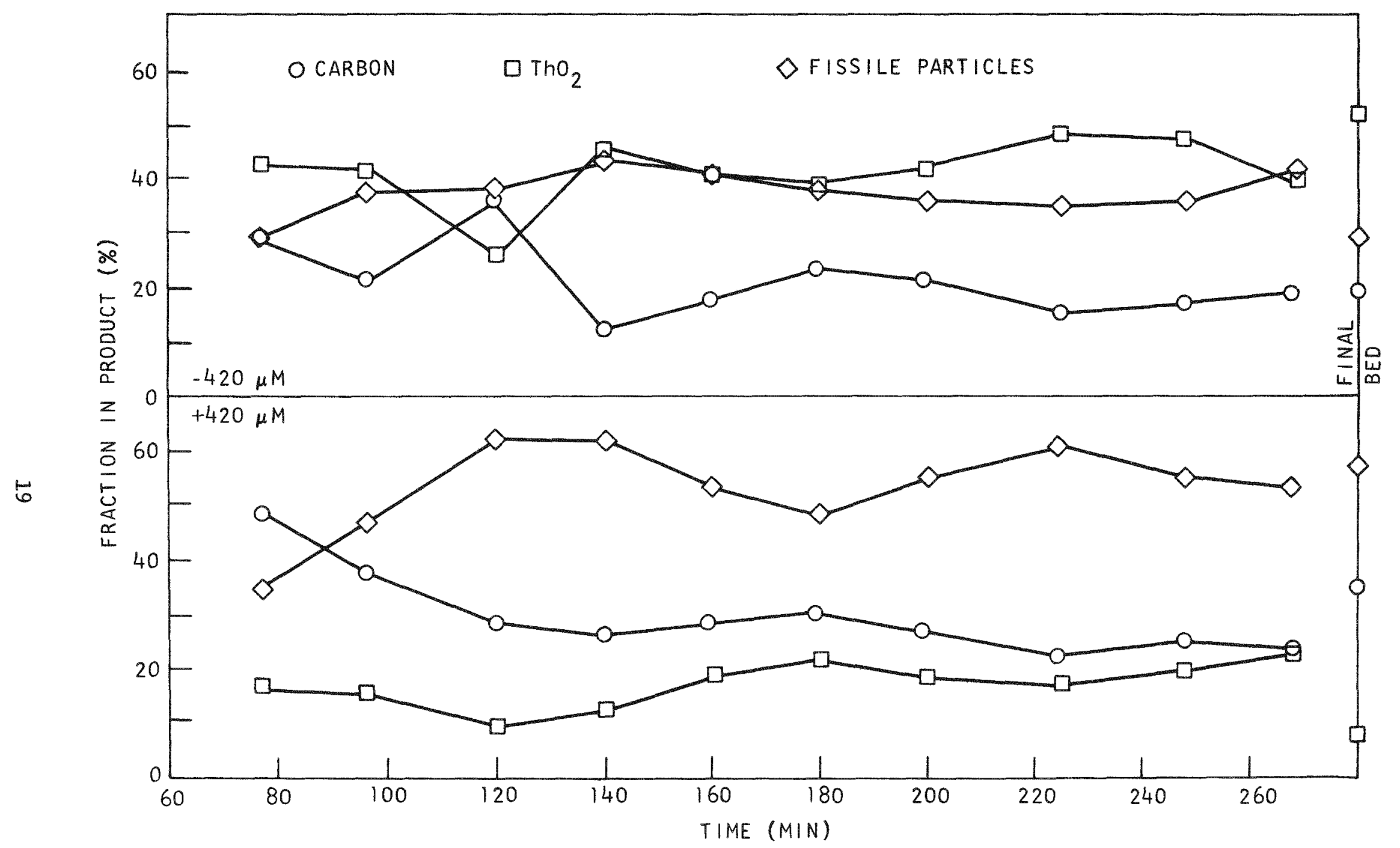

Fig. 5.4. Disposition of the components in material taken from the reactor in experiment F4B-104 


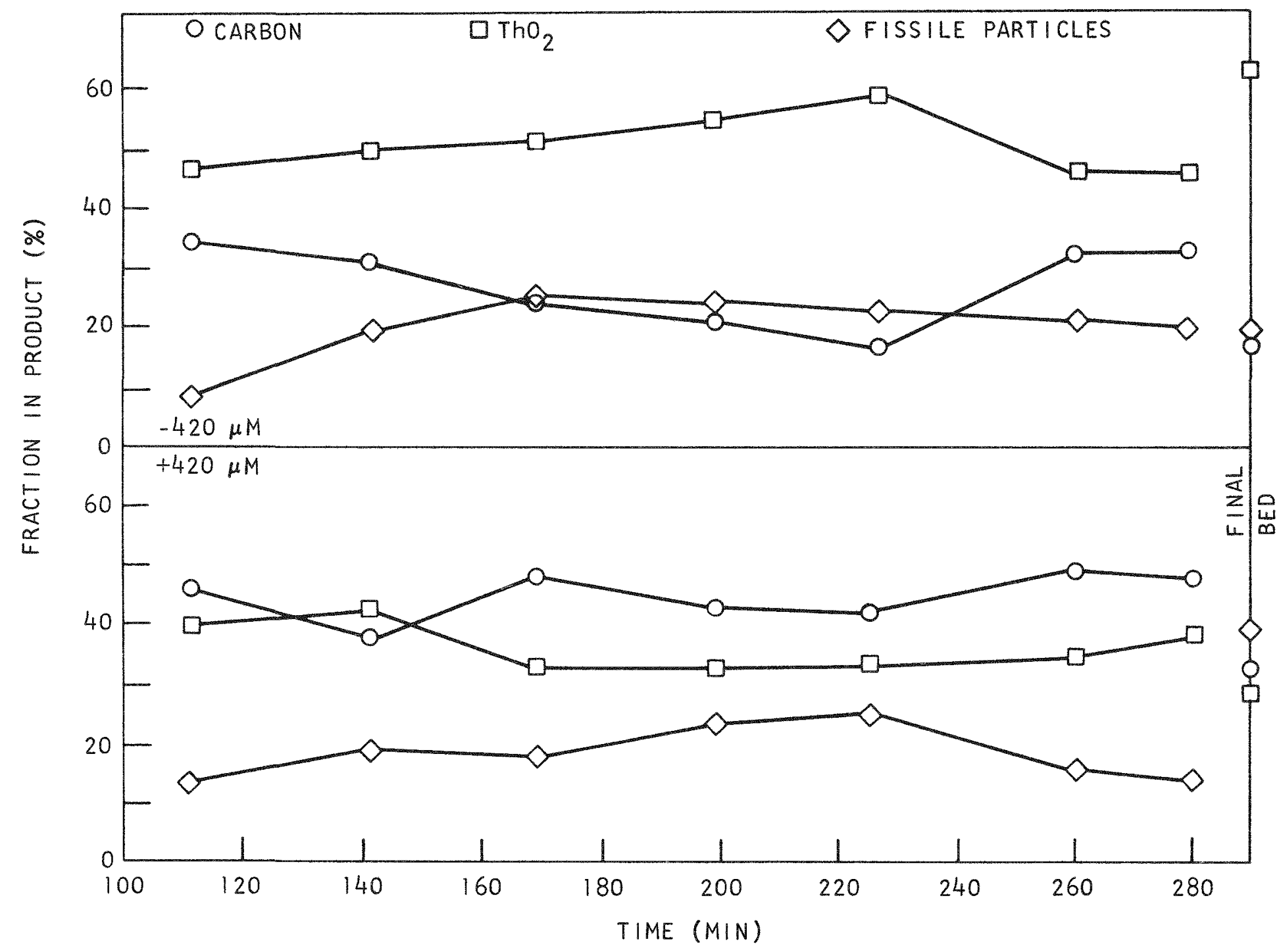

Fig. 5.5. Disposition of the components in material taken from the reactor in experiment F4B-107 
3. The $-420-\mu \mathrm{m}$ product that is feed for the ENDO burner contains about $20 \%$ carbon.

It was concluded from these two runs that there is no difficulty in operating continuously with a feed of crushed TRISO/BISO pitch-bonded rods.

A first attempt has been made to scale up the burning rate of the 4-in. EXO burner to larger burners and in particular to the 8 -in. burner. The temperatures of the offgas, shell coolant air, and reactor wall were measured, and the flow rate of coolant air to the shell was determined $(4.8 \mathrm{~kg} / \mathrm{min})$. The heat loss from the reactor wall via the shell was calculated to be $137.6 \mathrm{kcal} / \mathrm{ft}^{2}-\mathrm{min}$.

The heat balance, assuming that the composition of the combustion products is $8 \% \mathrm{CO}$ and $92 \% \mathrm{CO}_{2}$ and given the heat loss from the reactor shown in Fig. 5.5, was calculated. Based on the results of experiment F4B-78, the heat removed from the burner was measured at the following points (see Fig. 5.6):

1. In the off-gas $\left(850^{\circ} \mathrm{C}\right), \mathrm{H}_{1}$.

2. In the coolant gas from the shell $(\max ),. \mathrm{H}_{2}$.

3. Radiated from the cone $\left(750^{\circ} \mathrm{C}\right) \mathrm{H}_{3^{\circ}}$.

For the 4-in. burner:

Rate of combustion $=72 \mathrm{~g} / \mathrm{min}$,

Rate of heat generation $=518.4 \mathrm{kcal} / \mathrm{min}$,

Feed gas rate $=2201 / \mathrm{min}$ STP,

Feed gas $\mathrm{O}_{2}$ concentration, $\mathrm{f}=0.608 \mathrm{moles} / \mathrm{mole}$, 


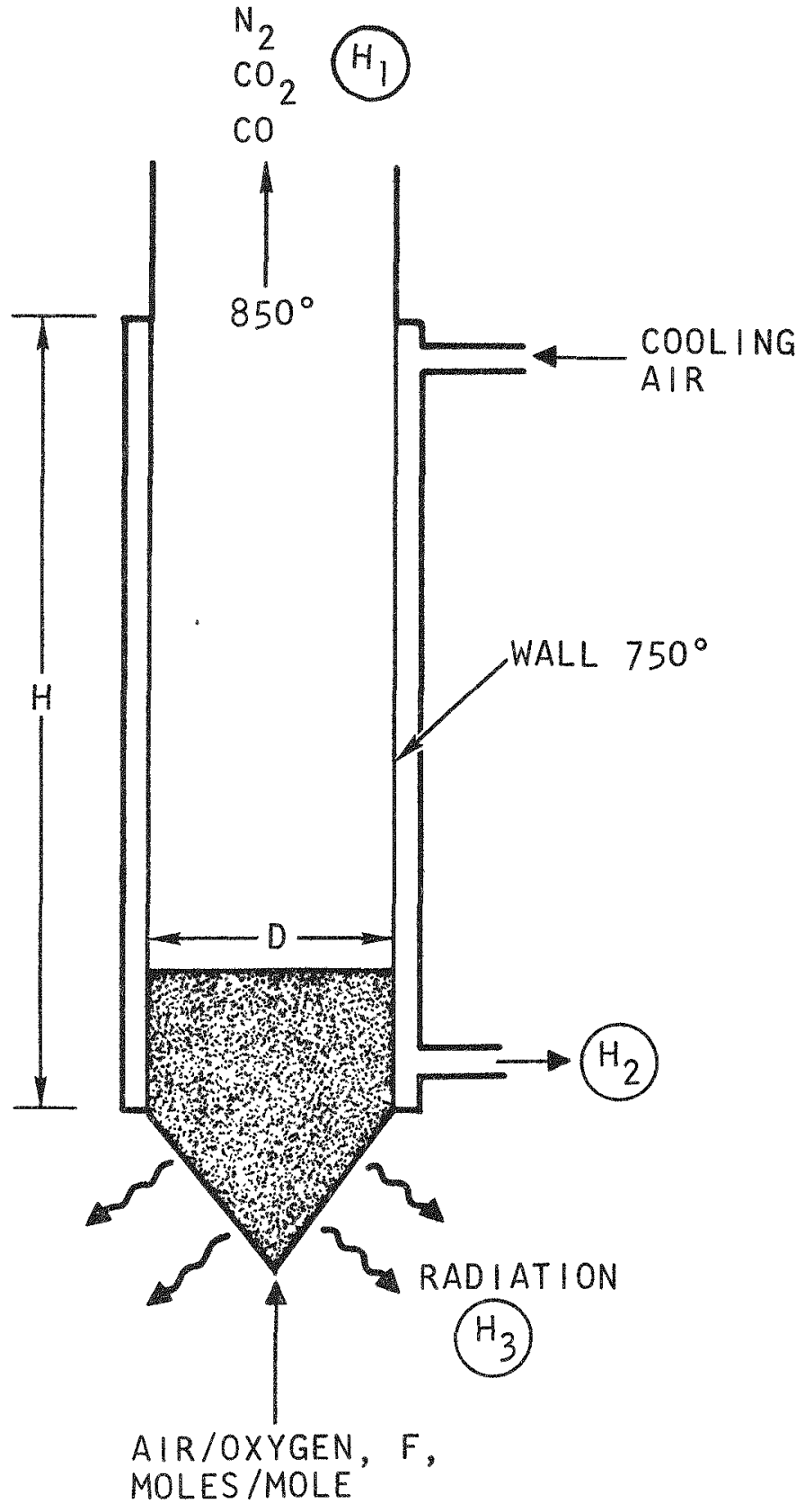

Fig. 5.6. Disposition of heat lost from the fluid-bed burner 
Diameter of the reactor, $\mathrm{d}=4$ in., and

Height of the she11, $h=36$ in.

Since the heat in equals heat out, then

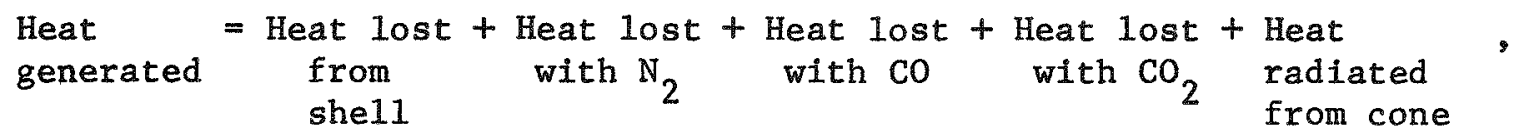

or

$53.10 d^{2} f=3.00 d h+3.54 d^{2}(1-f)+0.14 d^{2} f+5.12 d^{2} f+0.72 d^{2}$.

This equation simplifies to:

$$
\mathrm{f} \%=\frac{5.84 \mathrm{~h}}{\mathrm{~d}}+8.29 \mathrm{~mole}-\% \mathrm{O}_{2}
$$

so the heat generated, $\mathrm{q}$, is $53.10 \mathrm{~d}^{2} \mathrm{f} \mathrm{kcal} / \mathrm{min}$, and the burning rate, $r$, is $q / 7.2 \mathrm{~g} / \mathrm{min}$ carbon.

The values calculated for the 8 -in. reactor are then as follows:

Oxygen feed concentration, $f=52.1 \mathrm{moles} / \mathrm{mole}$

Heat generated, $\mathrm{q}=1771 \mathrm{kcal} / \mathrm{min}$

Burning rate, $r=245.9 \mathrm{~g} / \mathrm{min}$

These values will be checked when the 8 -in. reactor becomes fully operational.

4-in. ENDO Fluid Bed Burner. Seven experiments plus shakedown runs have been done with the 4-in. ENDO burner, and the results are summarized in Table 5.6. No difficulties were encountered during operation, and it is 
TABLE 5.6

RESULTS OF BATCH EXPERIMENTS DONE IN THE 4-IN. ENDO BURNER

\begin{tabular}{|c|c|c|c|c|c|c|c|c|c|c|c|}
\hline \multirow{3}{*}{$\begin{array}{l}\text { Run } \\
\text { No. }\end{array}$} & \multicolumn{3}{|c|}{ Feed } & \multicolumn{4}{|c|}{ Inerts } & \multicolumn{2}{|c|}{ Product } & \multirow{2}{*}{\multicolumn{2}{|c|}{$\begin{array}{c}\text { Burn Rate } \\
\text { (g/min) }\end{array}$}} \\
\hline & \multirow[b]{2}{*}{ Amount (g) } & \multirow[b]{2}{*}{ Type } & \multirow{2}{*}{$\begin{array}{l}\text { Burnable } \\
\text { Carbon } \\
(\%)\end{array}$} & \multirow[b]{2}{*}{ Amount (g) } & \multirow[b]{2}{*}{ Type } & \multirow[b]{2}{*}{ Size $(\mu \mathrm{m})$} & \multirow{2}{*}{$\begin{array}{l}\text { Burnable } \\
\text { Carbon } \\
(\%)\end{array}$} & \multirow[b]{2}{*}{ Amount $(g)$} & \multirow{2}{*}{$\begin{array}{l}\text { Burnable } \\
\text { Carbon } \\
(\%)\end{array}$} & & \\
\hline & & & & & & & & & & $\operatorname{Max}$ & Avg \\
\hline $\mathrm{R} 4 \mathrm{HFB}-7^{(\mathrm{a})}$ & 4090 & $\begin{array}{l}\text { TRISO- } \\
\text { TRISO }\end{array}$ & 5.3 & -- & $-\infty$ & $-\cdots$ & $-\cdots$ & -- & $-\cdots$ & $-\cdots$ & -- \\
\hline R4HFB-8 & 500 & Coke & 100 & 4000 & Alumina & $\begin{array}{c}-250+ \\
175\end{array}$ & 0 & 3977 & $<0.5$ & 22 & 16 \\
\hline R4HFB $-9^{(\mathrm{b})}$ & 3227 & $\begin{array}{l}\text { TRISO- } \\
\text { TRISO }\end{array}$ & 1.6 & 3789.5 & Alumina & $\begin{array}{c}-250+ \\
175\end{array}$ & 0 & 6868 & $<0.5$ & 4 & 2 \\
\hline $\mathrm{R} 4 \mathrm{HFB}-10$ & 1000 & $\begin{array}{l}\text { Crushed } \\
\text { TRISO- } \\
\text { Fertile }\end{array}$ & 20 & 5190 & Zirconia & $\begin{array}{c}-250+ \\
175\end{array}$ & 6.3 & 5457.6 & $<0.2$ & 35 & $22-25$ \\
\hline R4HFB-11 & $2507.6^{(c)}$ & $\begin{array}{l}\text { Crushed } \\
\text { TRISO- (c) } \\
\text { Fertile }\end{array}$ & $20^{(c)}$ & 4471 & Zirconia & $\begin{array}{c}-250+ \\
175\end{array}$ & 0 & 6821 & $<0.2$ & 26 & $22-23$ \\
\hline$R 4 H F D-12^{(d)}$ & 4404 & $\begin{array}{l}\text { TRISO- } \\
\text { Fertile }\end{array}$ & 3.5 & $-\infty$ & -- & $-\infty$ & $-\infty$ & -- & --- & -- & -- \\
\hline R4HFB-13 & $12,374.4$ & $\begin{array}{l}\text { TRISO- } \\
\text { Fertile }\end{array}$ & 20.3 & -- & -- & - & $-\infty$ & 9567.3 & 0.34 & 50 & 45.48 \\
\hline
\end{tabular}

(a) Burned hole in reactor wall due to insufficient gas flow to fluidize.

(b) Insufficient carbon to allow full ignition; only a slow burn rate.

(c) Run began with $500 \mathrm{~g}$ of $100 \%$ burnable coke.

(d) Insufficient carbon to allow full ignition; terminated run early. 
concluded that a carbon content of less than $0.5 \%$ can be readily achieved in the product. The burning rate is satisfactorily high, the heat being lost mostly by radiation from the reactor wall, which operates at red heat.

Experiments are now being planned that include continuous feed with batch and continuous take-off, determination of minimum fraction inerts required with ground particles, and maximum burning rate. In addition, the rig is being instrumented in preparation for automatic control.

8-in. Fluid Bed Burner. The 8-in. burner has been operated for $9.5 \mathrm{hr}$ at a burning rate of about $90 \mathrm{~g} / \mathrm{min}$ without trouble. A water heat-exchanger has now been installed to permit an increase in the burning rate to $250 \mathrm{~g} / \mathrm{min}$, a figure calculated from the scaled-up results achieved on the 4-in. Exo burner. An air heat-exchanger has been designed that will be installed in the offgas line in front of the filters. 


\title{
TASK VIII
}

PHYSICS AND FUEL MANAGEMENT

\author{
FUEL TEST ELEMENT
}

\section{Element Design}

Preliminary designs on various test element concepts for phase 3 are currently being evaluated. Each design will be considered as it applies to the phase 3 test parameters.

\section{Element Fabrication}

Fuel particles for the phase 2 elements are complete, and final quality control inspections are in progress. Fuel rod fabrication equipment is ready and fabrication has begun. All other components are ready for assembly. 
TASK IX

FUEL MATERIALS DEVELOPMENT

\section{COATED PARTICLE IRRADIATIONS}

A series of capsule irradiations is being conducted to evaluate both startup and recycle fuel systems for a large HTGR under the expected irradition environments.

\section{Capsule P13L}

Postirradiation examination of capsule P13L has been completed except for detailed analyses of the temperature histories of the fuel samples. The results are presented in Table 9.1 and representative photographs are given in Figs. 9.1 through 9.30. Several tentative conclusions can be drawn from this experiment (dependent upon final temperature analysis results).

The "reference" UC 2 TRISO-LTI particles $(50-\mu \mathrm{m}$ buffer - 20- $\mu \mathrm{m}$ inner PyC coating - 20- $\mu \mathrm{m} \mathrm{SiC} \mathrm{-} 25 \mu \mathrm{m}$ outer PyC coating) had the best overa11 irradiation performance of the diluent particles tested at $900^{\circ}, 1300^{\circ}$, and $1500^{\circ} \mathrm{C}$. The UC 2 -TRISO particles with thinner buffer and inner pyrocarbon coatings had slight to moderate failure resulting from the attack of the silicon carbide layer by diffusing fission products and/or fuel. It appears that the coating thickness between the fuel kernel and SiC layer (or related parameters) is an important factor governing the amount and extent of silicon carbide attack by the metallics.

The UO ${ }_{2}$-TRISO fuel particles gave anomalous results because the particles irradiated at higher temperatures performed better than those at lower temperatures. Also, kernel migration was more pronounced in these samples than with the $\mathrm{UC}_{2}$-TRISO particles, which again is inconsistent with 
SUAMARY DESCRIPTION OF THE COATED PARTICLE SAMPLES TESTED IN CAPSULE P13L

\begin{tabular}{|c|c|c|c|c|c|c|c|c|c|c|c|c|c|c|c|c|c|c|c|c|c|}
\hline \multirow{4}{*}{$\begin{array}{l}\text { Batch } \\
\text { No. }\end{array}$} & \multirow{3}{*}{\multicolumn{2}{|c|}{$\begin{array}{c}\text { Coated } \\
\text { Partfcle(a) }\end{array}$}} & \multicolumn{10}{|c|}{ Coating } & \multirow{2}{*}{\multicolumn{2}{|c|}{ Fue1 Kerne1 }} & \multirow{2}{*}{\multicolumn{3}{|c|}{ Irradiation Conditions }} & \multirow{2}{*}{\multicolumn{4}{|c|}{$\begin{array}{c}\text { Postirrad, Exass. } \\
\text { (z fait. })\end{array}$}} \\
\hline & & & \multicolumn{2}{|c|}{ Buffer } & \multicolumn{2}{|c|}{$\begin{array}{c}\text { Inner } \\
\text { Isotroplc (LTI) }\end{array}$} & \multicolumn{2}{|c|}{ sic } & \multicolumn{3}{|c|}{ Outer Isotropic } & \multirow{3}{*}{$\begin{array}{c}\text { Total } \\
\text { Coating } \\
\text { Thickness } \\
\text { (um) }\end{array}$} & & & & & & & & & \\
\hline & & & Thick. & Density & Thick. & Density & & Density & Th1ck. & Density & & & \multirow[b]{2}{*}{ Type } & \multirow{2}{*}{$\begin{array}{l}\text { Size } \\
\text { ( } \mathrm{Mm})\end{array}$} & \multirow{2}{*}{$\begin{array}{l}\text { Burnup (b) } \\
\text { (: FIMA) }\end{array}$} & \multirow{2}{*}{$\begin{array}{l}\text { Temp } \\
\left({ }^{\circ} \mathrm{c}\right)\end{array}$} & \multirow{2}{*}{$\begin{array}{l}\text { Fase Dose } \\
\left(10^{21} \mathrm{n} / \mathrm{cm}^{2}\right)\end{array}$} & \multicolumn{2}{|c|}{ Macro } & \multicolumn{2}{|l|}{ Miscro } \\
\hline & Type & Pyc & $(1 \mathrm{n})$ & $\left(\mathrm{g} / \mathrm{cm}^{3}\right)$ & $(\gamma \mathrm{mi})$ & $\left(\mathrm{g} / \mathrm{cm}^{3}\right)$ & $(\mu \mathrm{m})$ & $\left(\mathrm{g} / \mathrm{em}^{3}\right)$ & $(\mu \mathrm{m})$ & $\left(\mathrm{g} / \mathrm{cm}^{3}\right)$ & $B A F$ & & & & & & & OPyc & sic & opyc & $51 \mathrm{c}$ \\
\hline $3516-47 \mathrm{E}$ & BISO & HII & 62 & 1.23 & -- & $-\infty$ & -- & - & 48 & 1.82 & 1.00 & 110 & uc $_{2}$ & 106 & 75 & 1475 & 7.1 & (i) & $\ldots$ & $85(c, d)$ & - \\
\hline $4403-113 E$ & Biso & $\operatorname{LTI}$ & 56 & 1.27 & -- & -. & -- & -- & 45 & 1.88 & 1.04 & 101 & $\mathrm{vc}_{2}^{2}$ & 106 & 75 & 1575 & $7,1(1)$ & (1) & -- & $98\left(c_{0} d\right)$ & .. \\
\hline $4413-5 E$ & TRISO & $\operatorname{LrI}$ & 53 & 1.30 & 24 & 1.83 & 20 & 3.20 & 23 & 1.80 & 1.08 & 120 & $v c_{2}^{+}$ & 106 & 75 & 1375 & 7.1 & 0.1 & 0.1 & 0 & $1.5^{(e)}$ \\
\hline $4413-67 \varepsilon$ & TRIso & $\operatorname{LTr}$ & 46 & 1.26 & 22 & 1.85 & 20 & 3.16 & 22 & 1.75 & 1.01 & 110 & $\mathrm{voO}_{2}^{2}$ & 124 & 75 & 1450 & 7.1 & 0.2 & 0.2 & 0 & $1.4^{(\xi)}$ \\
\hline $4263-75 \mathrm{E}$ & TRISO & $\operatorname{ITI}$ & 48 & 1.23 & 22 & 1.87 & 19 & 3.18 & 50 & 1.83 & 1.00 & 119 & $(\mathrm{Th}, \mathrm{u}) \mathrm{C}_{2}(\mathrm{~g})$ & 200 & 26 & 1575 & 7.1 & 0 & 0 & 0 & $1.5(\mathrm{e})$ \\
\hline 4613-35E & B1so & LTI & 37 & 1.23 & -- & - & -- & - & 57 & 1.85 & 1.00 & 21.4 & $\mathrm{vo}_{2}{ }^{2}$ & 124 & 75 & 1375 & 7.1 & 6 & - & $13(c)$ & - \\
\hline $3516-39 \mathrm{E}$ & TRISO & HTI & 55 & 1.34 & 16 & 1.83 & 20 & 3.20 & 19 & 1.86 & 1.09 & 110 & $\mathrm{uc}_{n}$ & 106 & $75^{\circ}$ & 1225 & 7.8 & 88 & 4 & 88 & 0 \\
\hline $4403-113 \mathrm{E}$ & BISO & LTr & 56 & 1.27 & -- & -- & -- & -- & 45 & 1.88 & 1.04 & 103 & $\mathrm{uc}_{2}^{2}$ & 106 & 75 & 1275 & 7.8 & 30 & -.. & 18 & -. \\
\hline$\angle 403-1438$ & rriso & LTI & 53 & 1.30 & 24 & 1.83 & 20 & 3.20 & 26 & 1.90 & 1.05 & 123 & $\mathrm{vc}_{2}^{2}$ & 106 & 75 & 1250 & 7.8 & 0.1 & 0.1 & 0.3 & 0.3 \\
\hline $3516-35 \mathrm{E}$ & TRISO & HT I & 46 & 1.29 & 14 & 1.87 & 16 & 3.20 & 20 & 1.73 & 1.00 & 96 & $\mathrm{uc}_{2}^{2}$ & 106 & 75 & 1350 & 7.8 & 2.5 & 2.2 & $3.5^{(\mathrm{h})}$ & $7(\mathrm{e})$ \\
\hline $4413-7 \mathbb{E}$ & TRISO & 2II & 46 & 1.29 & 14 & 1.87 & 16 & 3.20 & 22 & 1.85 & 1.12 & 98 & $\mathrm{uc}_{2}{ }_{2}$ & 106 & 75 & 1200 & 7.8 & 4.0 & 3.7 & 6 & $9(e)$ \\
\hline $4413-21 \mathrm{E}$ & TRiso & $\operatorname{LTI}$ & 44 & 1.22 & 21 & 1.78 & 21 & 3.17 & 19 & 1.91 & 1.00 & 105 & $v c_{2}^{2}$ & 106 & 75 & 1250 & 7.8 & 0.3 & 0.2 & 0.2 & $1(e)$ \\
\hline 3516-33E & TRISO & ATI & 49 & 1.33 & 17 & 1.91 & 20 & 3.20 & 22 & 1.72 & 1.00 & 108 & $\mathrm{uc}_{2}$ & 106 & 75 & 1275 & 7.8 & 1.3 & 1.0 & & $2.5(\mathrm{e})$ \\
\hline $4403-81 \mathrm{E}$ & B1so & $\operatorname{LxI}$ & 56 & 1.17 & -- & - & - & -- & 52 & 1.83 & 1.06 & 108 & $v c_{2}$ & 106 & 75 & 1225 & 7.8 & 0.2 & - & $0.6^{(d)}$ & - \\
\hline $4413-5 E$ & rRIso & $\operatorname{LrI}$ & 53 & 1.30 & 24 & 1.83 & 20 & 3.20 & 23 & 1.80 & 1.08 & 120 & $\mathrm{uc}_{2}^{2}$ & 106 & 75 & 1250 & 7.8 & 0.1 & 0.1 & 0.3 & $0.5(e)$ \\
\hline $4413-35 E$ & BIsa & LTI & 57 & 1.23 & -- & -- & -- & - & 57 & 1.85 & 1.00 & 114 & $\mathrm{vo}_{2}^{2}$ & 124 & 75 & 1275 & 7.8 & 5.5 & - & $17(c)$ & - \\
\hline $4413-67 \mathrm{E}$ & rRISO & LTI & 46 & 1.26 & 22 & 1.85 & 20 & 3.16 & 22 & 1.75 & 2.01 & 110 & $\mathrm{vo}_{2}^{2}$ & 124 & 75 & 1275 & 7.8 & 0.6 & 0.6 & & $2.5^{(e)}$ \\
\hline $3516-47 \mathrm{E}$ & Biso & HTI & 62 & 1.23 & $-\cdots$ & -- & - & - & 48 & 1.82 & 1.00 & 110 & $v c_{2}^{2}$ & 106 & 75 & 1250 & 7.8 & $1.2^{(1)}$ & - & $3.8(c)$ & - \\
\hline $4403-1458$ & BIso & LTI & 57 & 1.29 & -- & $\sim$ & -- & - & 20 & 1.90 & 1.11 & 77 & $\mathrm{UC}_{2}$ & 106 & 75 & 1350 & 7.2 & (1) & - & $90(c, d)$ & - \\
\hline $3516-57 \mathrm{E}$ & Btso & нTY & 59 & 1.24 & -- & - & $\ldots$ & - & 21 & 1.82 & 0.96 & 80 & $\mathbf{U C}_{2}$ & 1.06 & 75 & 1350 & 7.2 & (1) & $\ldots$ & ${ }_{50}(c, d)$ & -. \\
\hline $4413-29 \mathrm{E}$ & BIso & $\operatorname{LTI}$ & 59 & 1.24 & -- & -- & - & -- & 24. & 1,82 & 1.00 & 83 & $\mathrm{uc}_{2}^{2}$ & 106 & 75 & 1325 & 7.2 & (1) & - & ${ }_{10}(c, d)$ & $\ldots$ \\
\hline $4423-67$ & TRISO & LTI & 59 & 1.22 & 20 & $(j)$ & 21 & 3.22 & 22 & 1.90 & 1.02 & 122 & $\mathrm{Thc}_{2}$ & 530 & 7 & 1225 & 7.2 & 1.6 & 0.4 & 1.8 & $2,4(e)$ \\
\hline $4423-89$ & BIsO & LxI & 64 & -- & -- & -- & - & - & 89 & 1.72 & 0.97 & 153 & $\mathrm{Thc}_{2}{ }^{2}$ & 530 & 7 & 1175 & 7.2 & 0 & -- & 0 & $\ldots$ \\
\hline $4413-75$ & Biso & LTI & 69 & - & -- & $\ldots$ & - & - & 85 & 1.89 & 1.02 & 154 & $\mathrm{ThO}_{2}^{2}$ & 576 & 7 & 1325 & 7.2 & 14 & - & 12 & - \\
\hline $3516-47 \mathrm{E}$ & BIso & HT I & 62 & 1.23 & - & - & - & - & 48 & 1.82 & 1.00 & 110 & $\mathrm{wc}_{2}$ & 106 & 60 & 875 & 5.8 & 2.9 & - & $9.5^{(\mathrm{h})}$ & - \\
\hline 4403-113E & BIso & LxI & 56 & 1.27 & -- & - & - & $-\infty$ & 45 & 1.88 & 1.04 & 101 & $\mathrm{vc}_{2}^{2}$ & 106 & 60 & 850 & 5.8 & 0.1 & -- & 0.4 & -- \\
\hline $4413-5 E$ & TRISO & LTI & 53 & 1.30 & 24 & 1.83 & 20 & 3.20 & 23 & 1.80 & 1.08 & 120 & $\mathrm{uc}_{2}^{2}$ & 106 & 60 & 850 & 5.8 & 0 & 0 & 0.2 & 0 \\
\hline $4263-75 E$ & TRISO & LII & 48 & 1.23 & 22 & 1.87 & 19 & 3.18 & 30 & 1.83 & 1.00 & 119 & $(\mathrm{Th}, \mathrm{U}) \mathrm{C}_{2}(\mathrm{~s})$ & 200 & 20 & 925 & 5.8 & 0.2 & 0 & 0 & 0 \\
\hline $4413-67 E$ & TRiso & LTI & 46 & 1.26 & 22 & 1.85 & 20 & 3.16 & 22 & 1.75 & 1.01 & 110 & $\mathrm{vo}_{2}{ }^{2}$ & 124 & 60 & 875 & 5.8 & 0.1 & 0.1 & $g^{(h)}$ & 0.6 \\
\hline $4413-35 E$ & Biso & LII & 57 & 1.23 & | & -- & - & -- & 57 & 1.85 & 1.00 & 114 & $\mathrm{vo}_{2}^{2}$ & 224 & 60 & 850 & 5.8 & 0.1 & - & 1 & -- \\
\hline
\end{tabular}

(a) BisO deaotes a coat ing sequence of huffer and LTI or HTI laotrople F'yC; TRISO denotes a coating sequence of buffer, Inner 1stropic (b) Est Imate, analyses in progress.

(c) Some particie fallure as a result of fuel migrating (diffusing) (d) through the coaking.

Some particle fallure resulting fro i reactions with fuel or

(e) Some SIC layer fallure reaulting from chemical attack

by fuel or ElBsion products.

(s) Falled particleas were defect1ve; without the Inner PyC layer. (g) Thor ium-to-uran 1um rat 10 2.25 .

(h) Some particle fallure resulting from reactions with

fuel kernels of other particles with broken coatings.

(1) No fallure estimate; particles :emained atuck in
graphite container.

(j) This batch was prepared 1n production coaters out to,
and tncluding, the SIC layer; Ianer 1Botropic density 

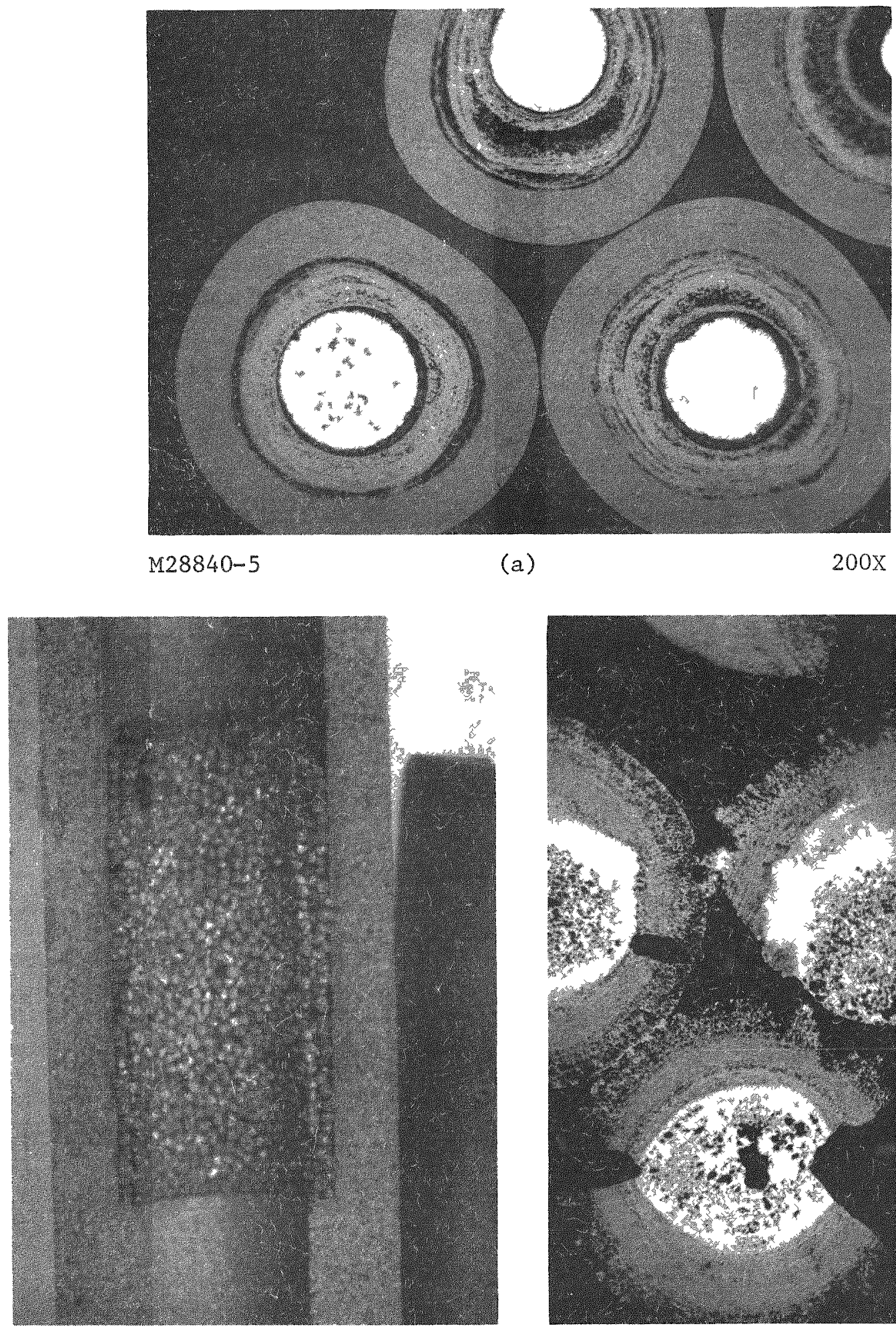

$5386-2$

(b)

$7 X$

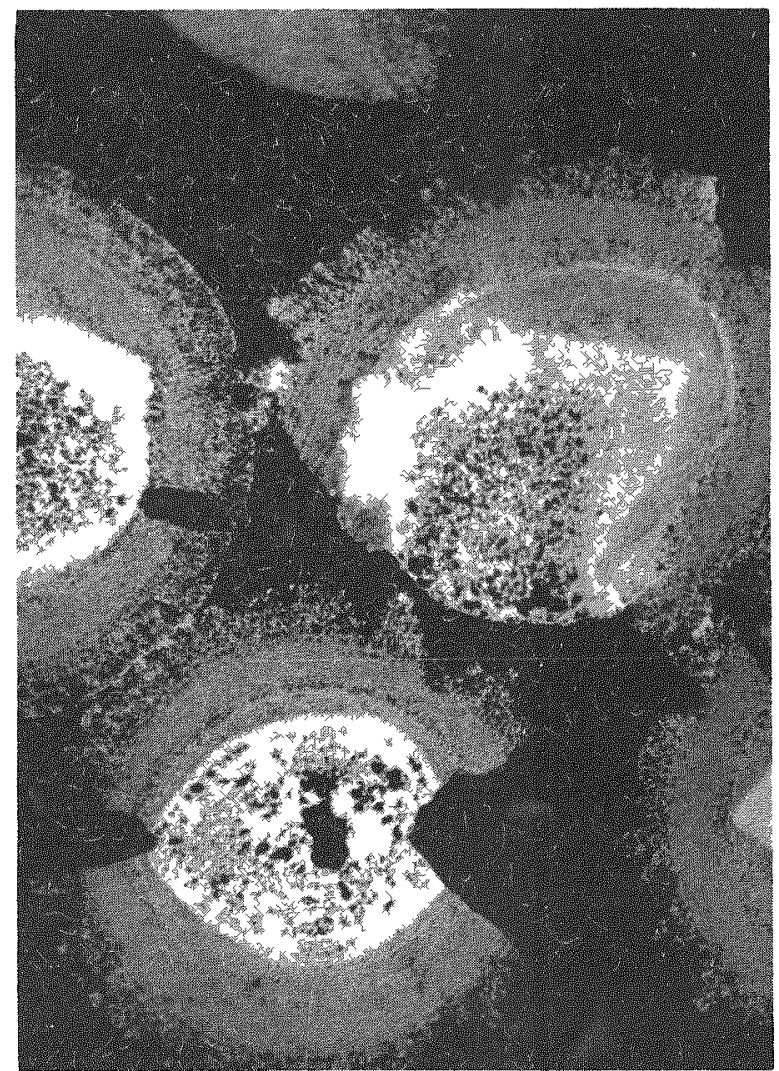

M386-54

(c)

$75 \mathrm{X}$

Fig. 9.1. Photographs of UC2 BISO-HTI coated particle batch 3516-47:

(a) before irradiation; (b) and (c) after irradiation in capsule $\mathrm{P} 13 \mathrm{~L}$ to $7.1 \times 10^{21} \mathrm{n} / \mathrm{cm}^{2}$ at approximately $1475^{\circ} \mathrm{C}$ to burnups of approximately $75 \%$ FIMA 

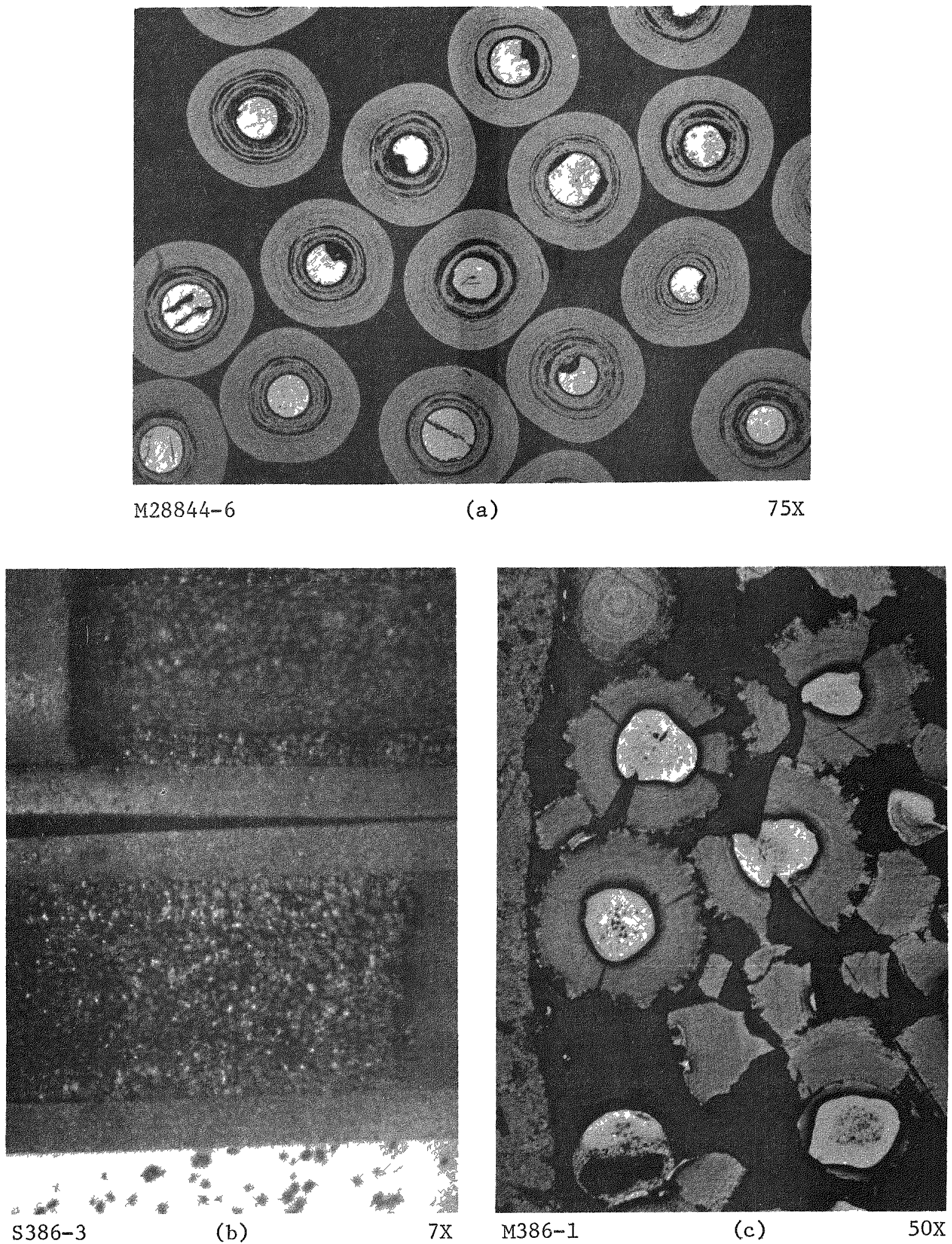

Fig. 9.2. Photographs of UC 2 BISO-LTI coated particle batch 4403-113: (a) before irradiation; (b) and (c) after irradiation in capsule $\mathrm{P} 13 \mathrm{~L}$ to $7.1 \times 10^{21} \mathrm{n} / \mathrm{cm}^{2}$ at approximately $1575^{\circ} \mathrm{C}$ to burnups of approximately $75 \%$ FIMA 


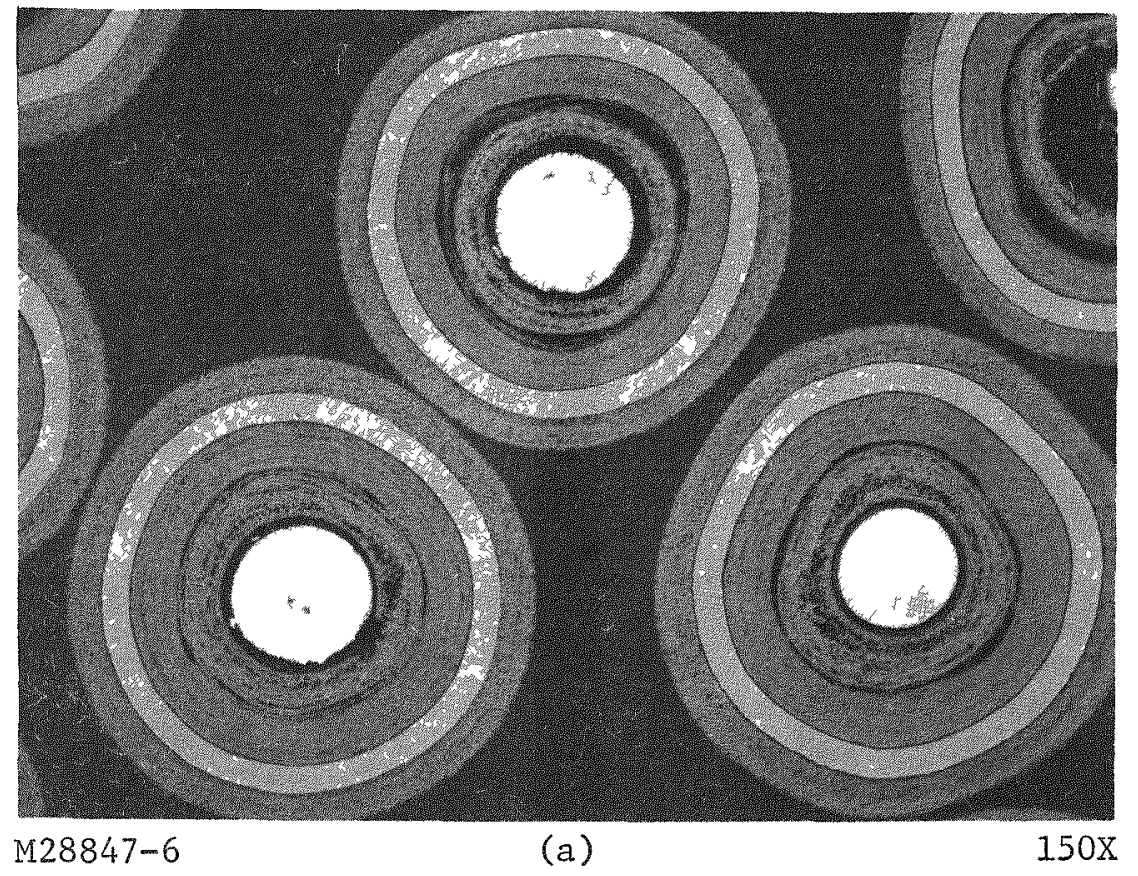

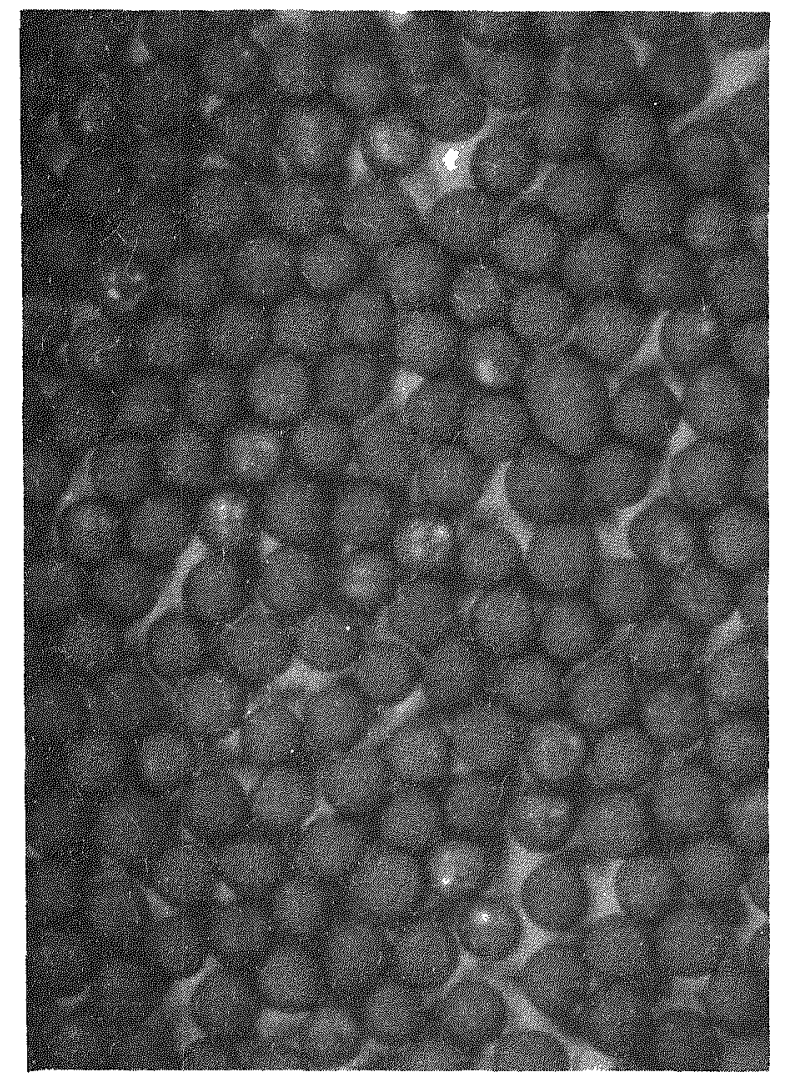

S386-5

(b)

$20 \mathrm{X}$

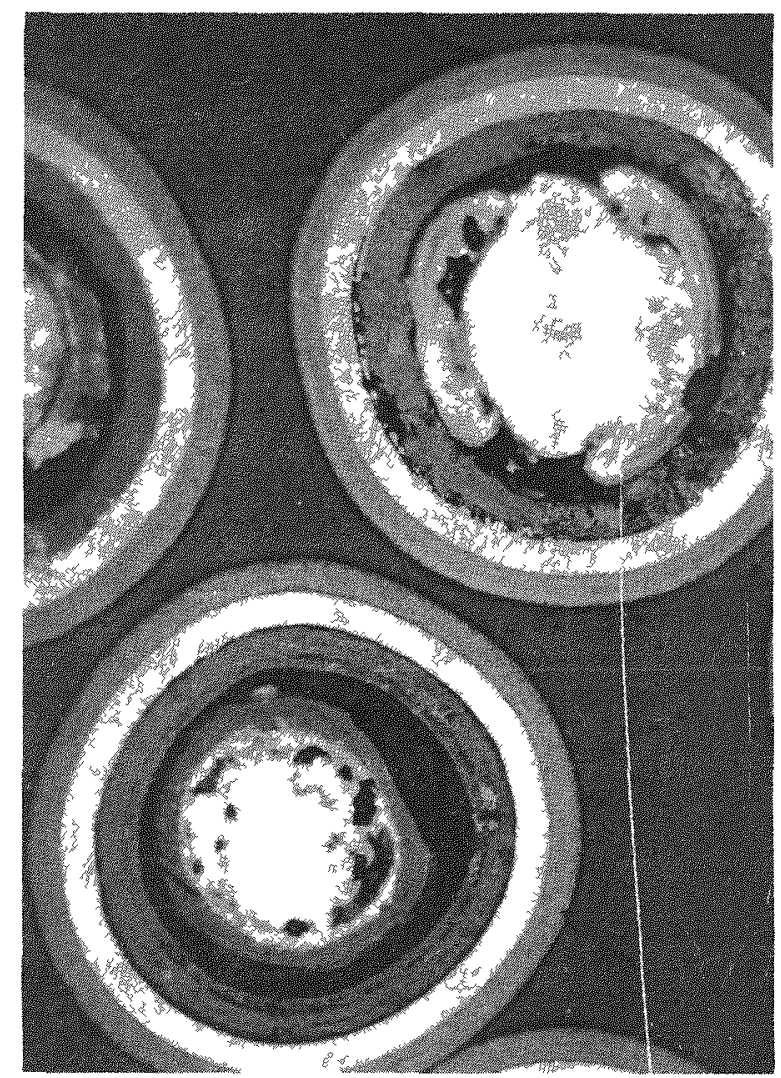

M386-156

(c)

$190 \mathrm{X}$

Fig. 9.3. Photographs of UC 2 TRISO-LTI coated particle batch 4413-5:

(a) before irradiation; (b) and (c) after irradiation in capsule P13L to $7.1 \times 10^{21} \mathrm{n} / \mathrm{cm}^{2}$ at approximately $1375^{\circ} \mathrm{C}$ to burnups of approximately $75 \%$ FIMA 

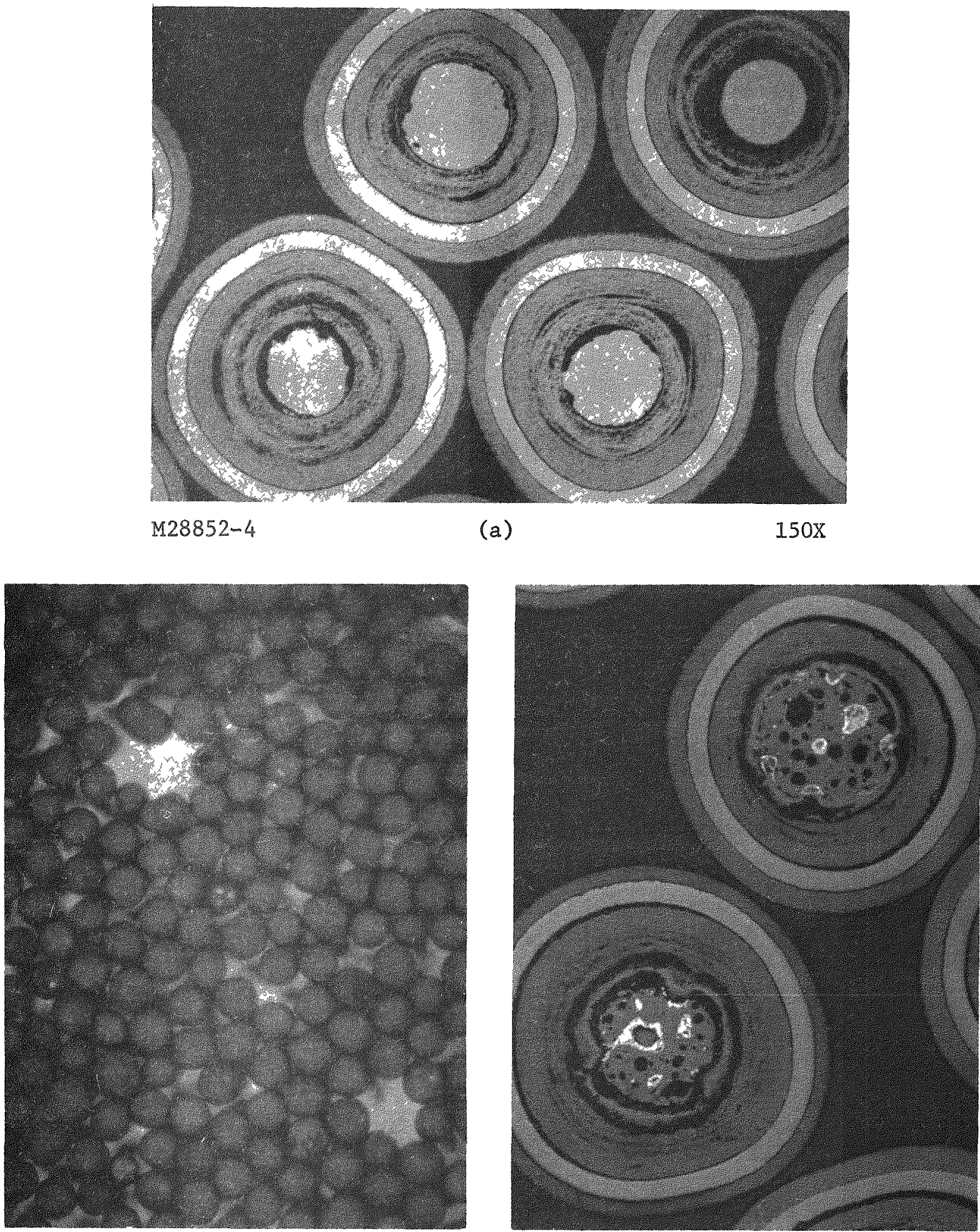

\$386-8

(b)

20X M386-37

(c)

$150 \mathrm{X}$

Fig. 9.4. Photographs of $\mathrm{UO}_{2}$ TRISO-LTI coated particle batch 4413-67: (a) before irradiation; (b) and (c) after irradiation in capsule P13L to $7.1 \times 10^{21} \mathrm{n} / \mathrm{cm}^{2}$ at approximately $1450^{\circ} \mathrm{C}$ to burnups of approximately $75 \%$ FIMA 

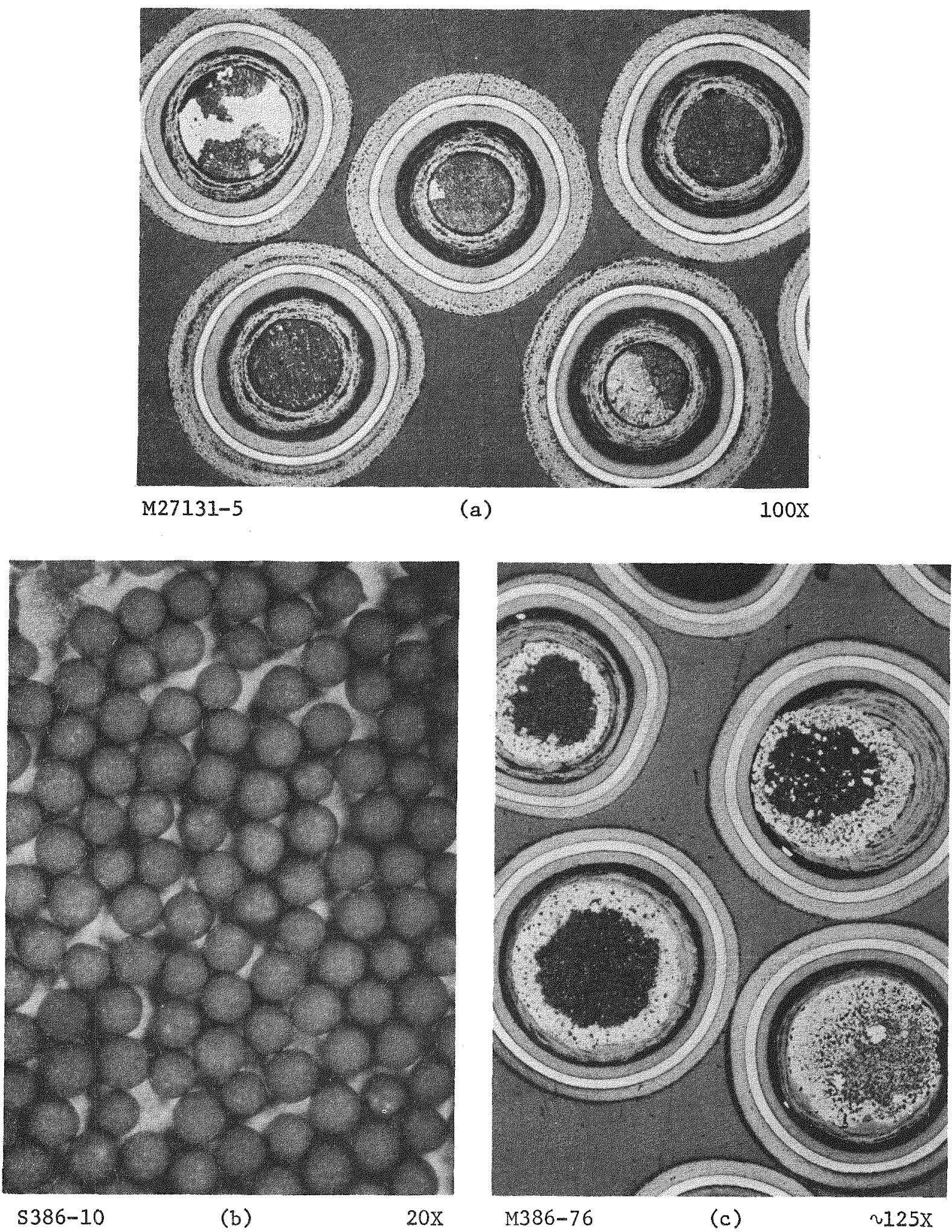

Fig. 9.5. Photographs of (Th,U) $C_{2}$ TRISO-LTI coated particle batch 4263-75: (a) before irradiation; (b) and (c) after irradiation in capsule $\mathrm{P} 13 \mathrm{~L}$ to $7.1 \times 10^{21} \mathrm{n} / \mathrm{cm}^{2}$ at approximate $1 \mathrm{y} 1575^{\circ} \mathrm{C}$ to burnups of approximately $26 \%$ FIMA 

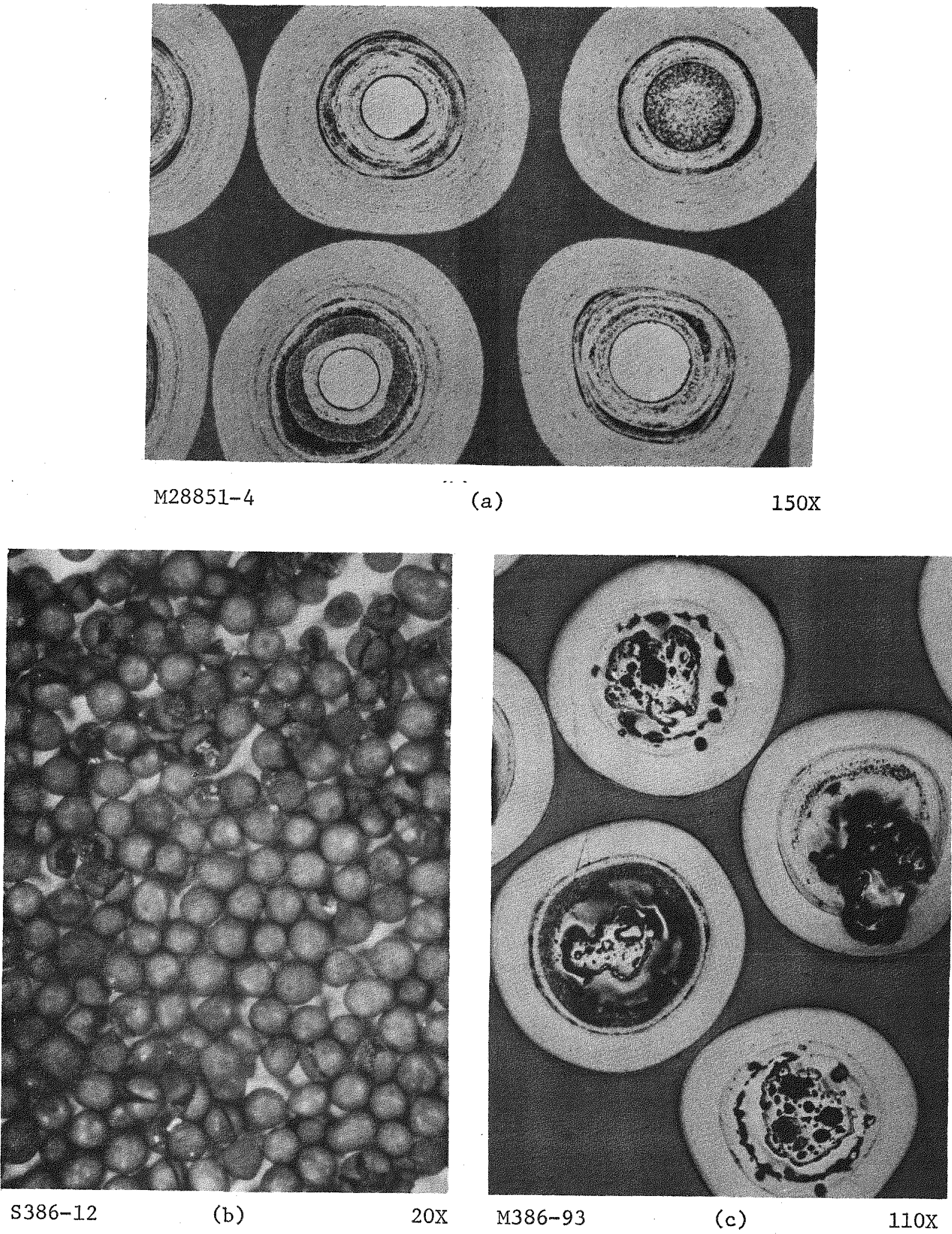

Fig. 9.6. Photographs of $\mathrm{UO}_{2}$ BISO-LTI coated particle batch 4413-35: (a) before irradiation; (b) and (c) after irradiation in capsule P13L to $7.1 \times 10^{21} \mathrm{n} / \mathrm{cm}^{2}$ at approximately $1375^{\circ} \mathrm{C}$ to burnups of approximately $75 \%$ FIMA 

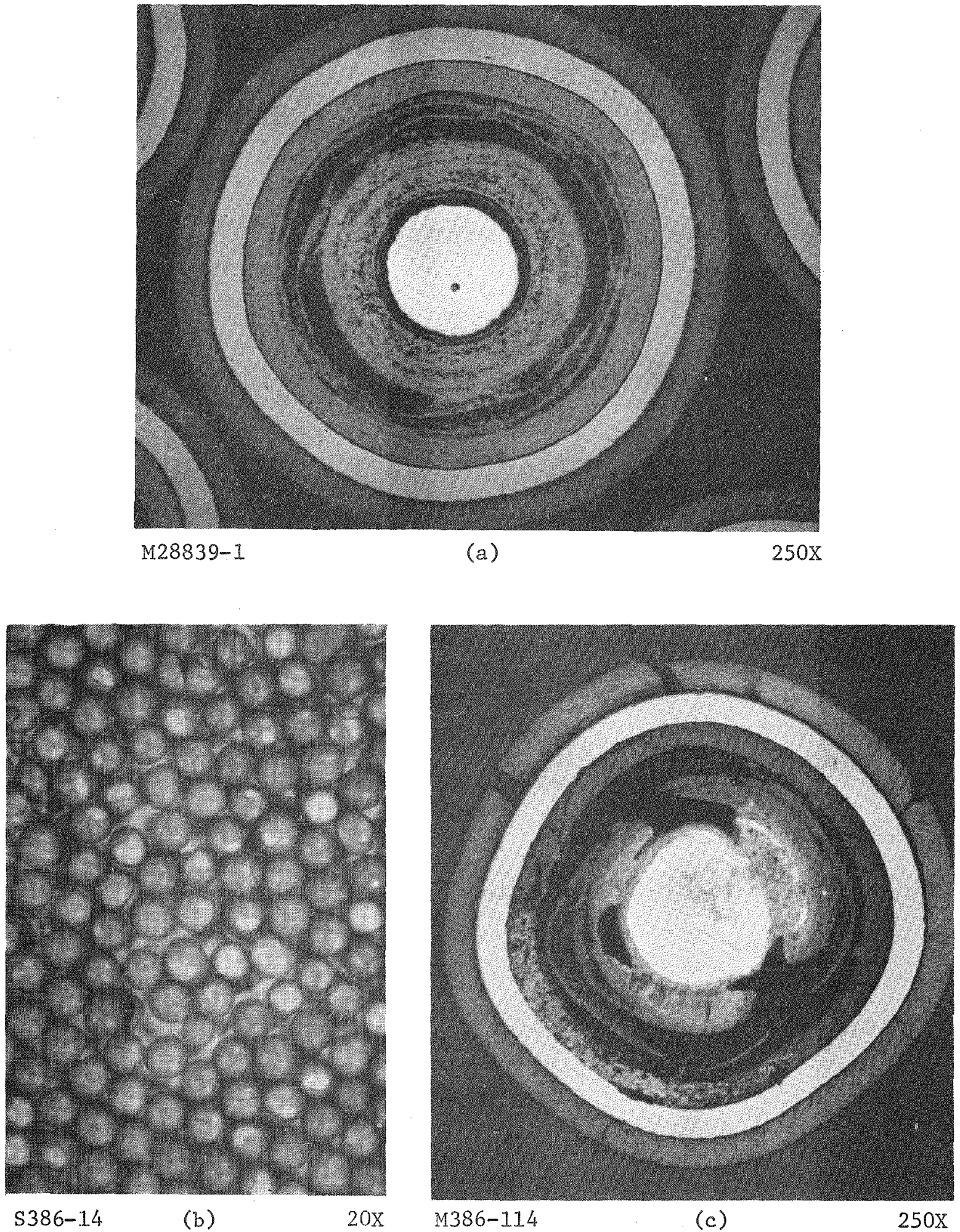

Fig. 9.7. Photographs of $\mathrm{UC}_{2}$ TRISO-HTI coated particle batch 3516-39: (a) before irradiation; (b) and (c) after irradiation in capsule

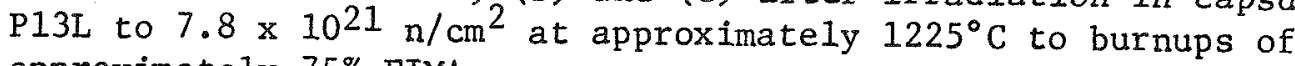
approximately $75 \%$ FIMA 


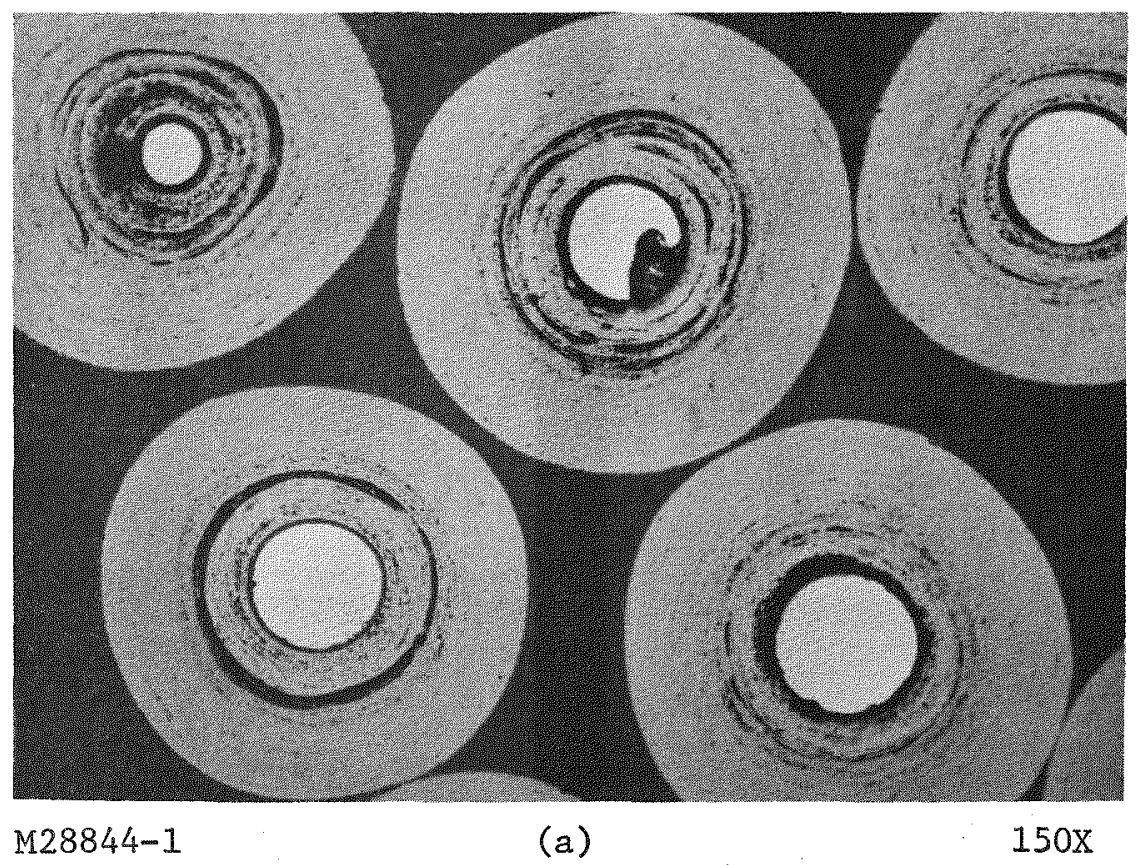

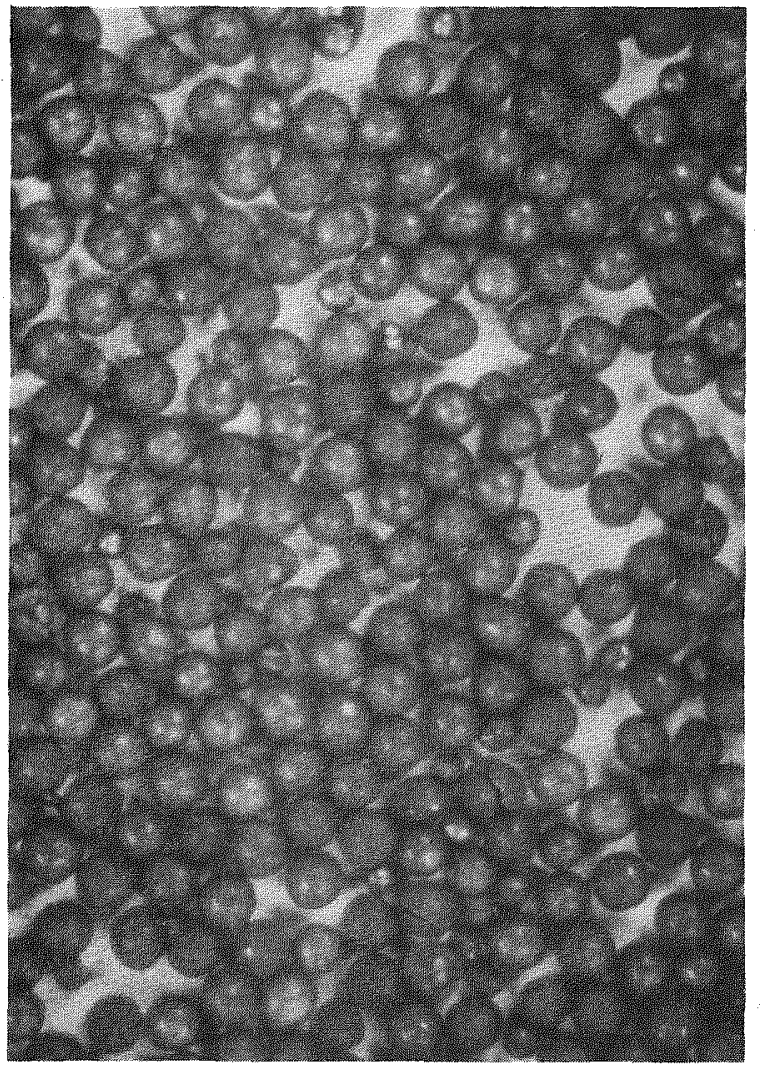

S $386-17$

(b)

$20 \mathrm{x}$

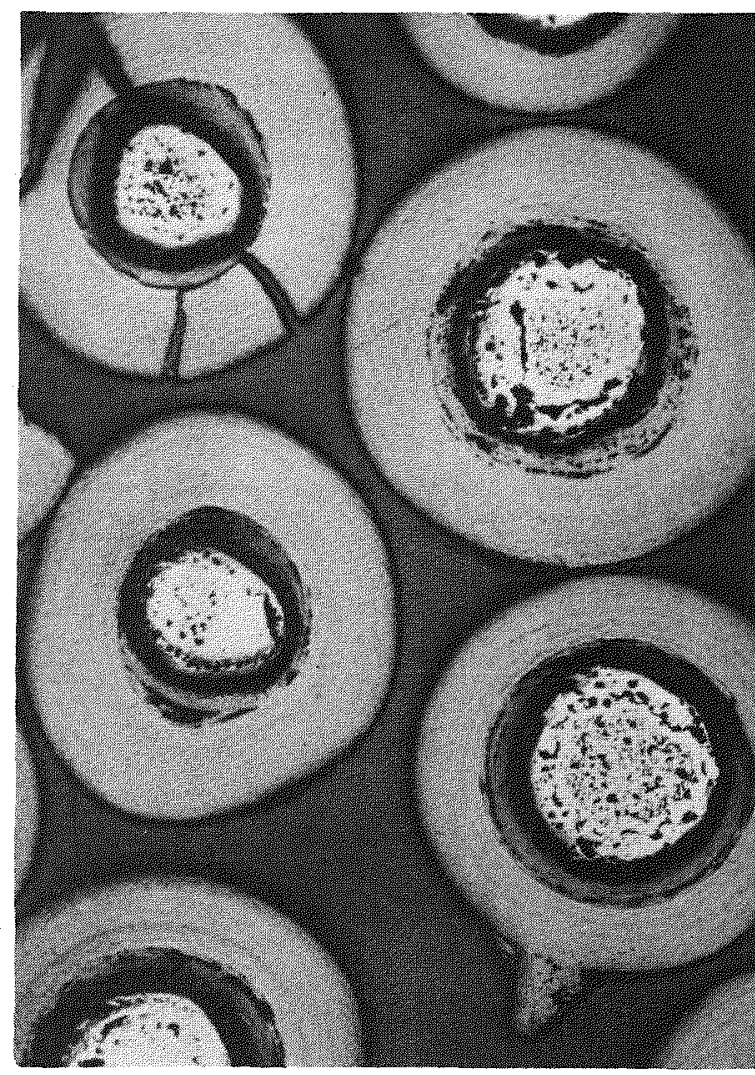

M386-120

(c)

$150 \mathrm{x}$

Fig. 9.8. Photographs of UC2 BISO-LTI coated particle batch 4403-113: (a) before irradiation; (b) and (c) after irradiation in capsule PI3L to $7.8 \times 10^{21} \mathrm{n} / \mathrm{cm}^{2}$ at approximately $1275^{\circ} \mathrm{C}$ to burnups of approximate1y $75 \%$ FIMA 

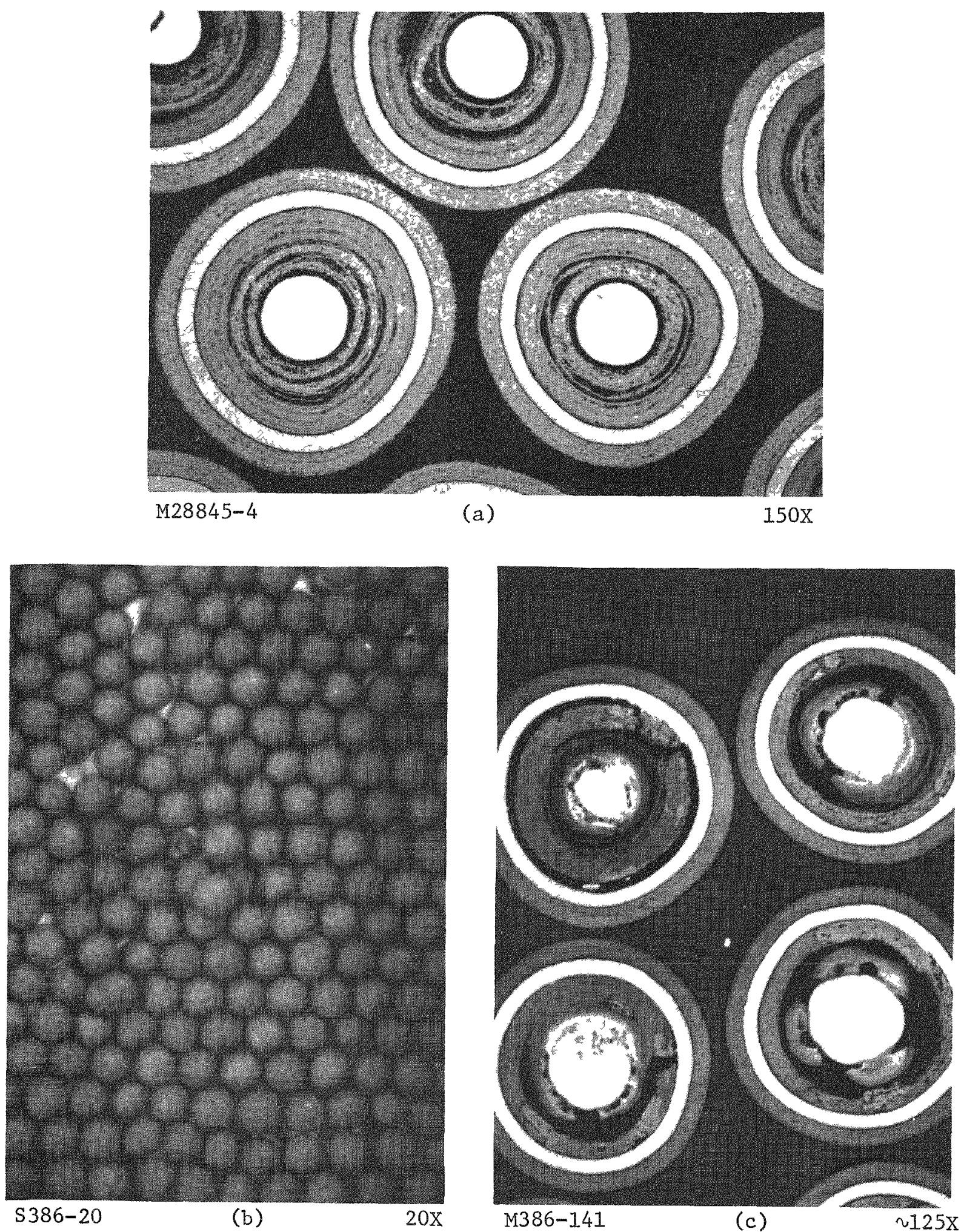

Fig. 9.9. Photographs of $\mathrm{UC}_{2}$ TRISO-LTI coated particle batch 4403-143: (a) before irradiation; (b) and (c) after irradiation in capsule P13L to $7.8 \times 10^{21} \mathrm{n} / \mathrm{cm}^{2}$ at approximately $1250^{\circ} \mathrm{C}$ to burnups of approximately $75 \%$ FIMA 


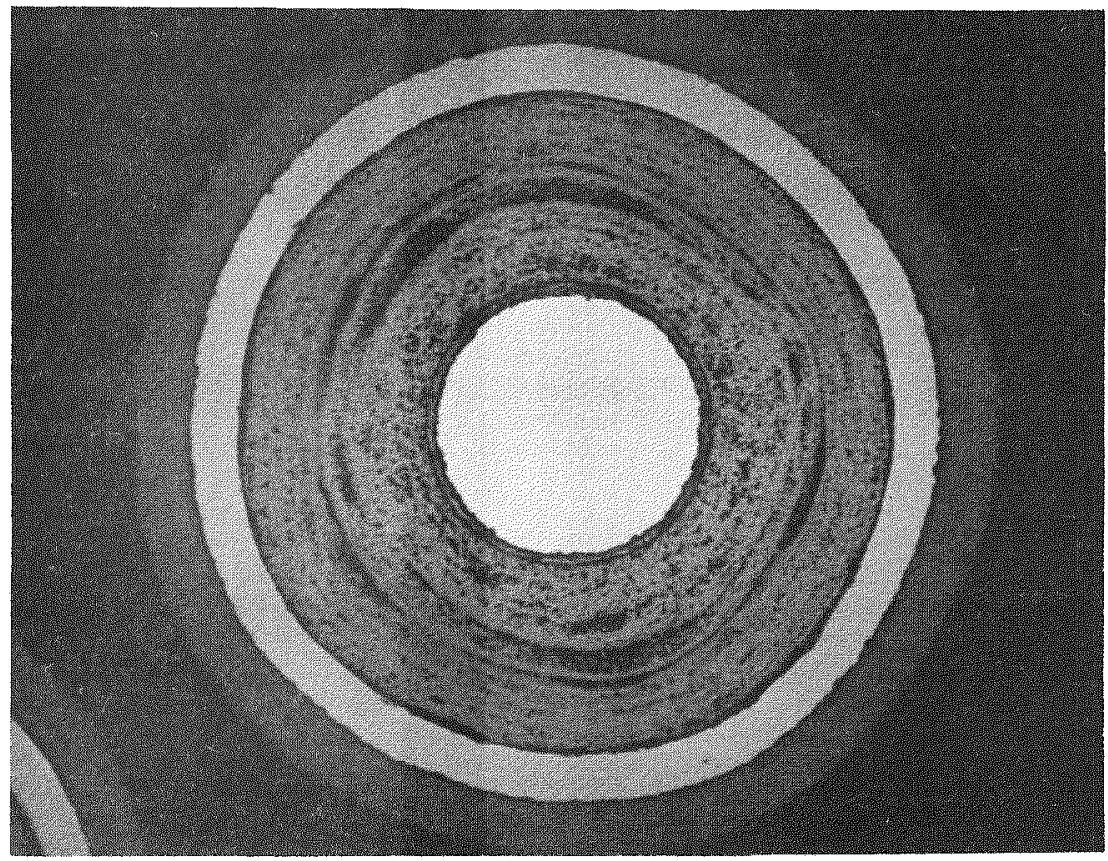

M28838-3

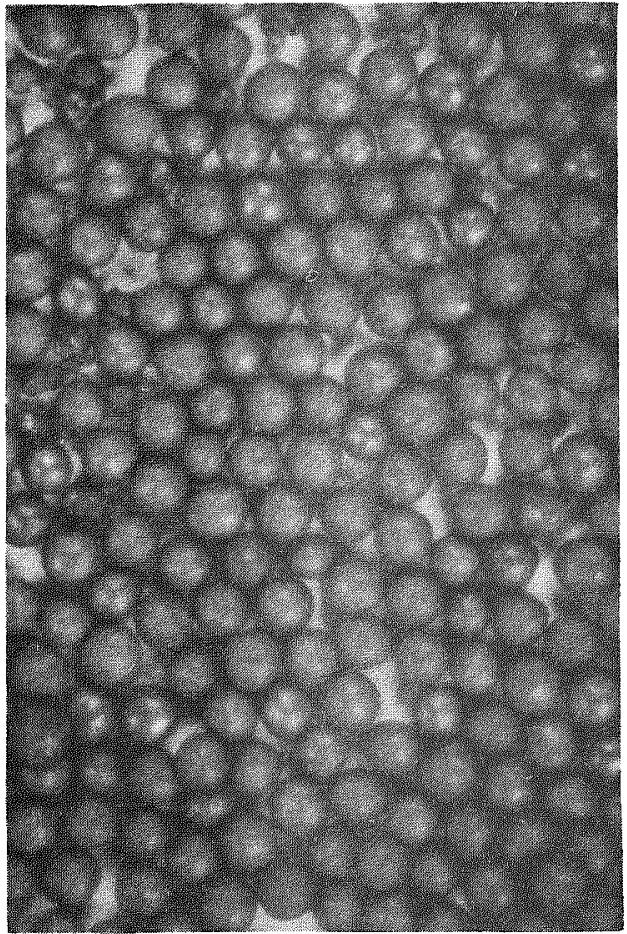

S $386-22$

(b)

(a)

$300 x$

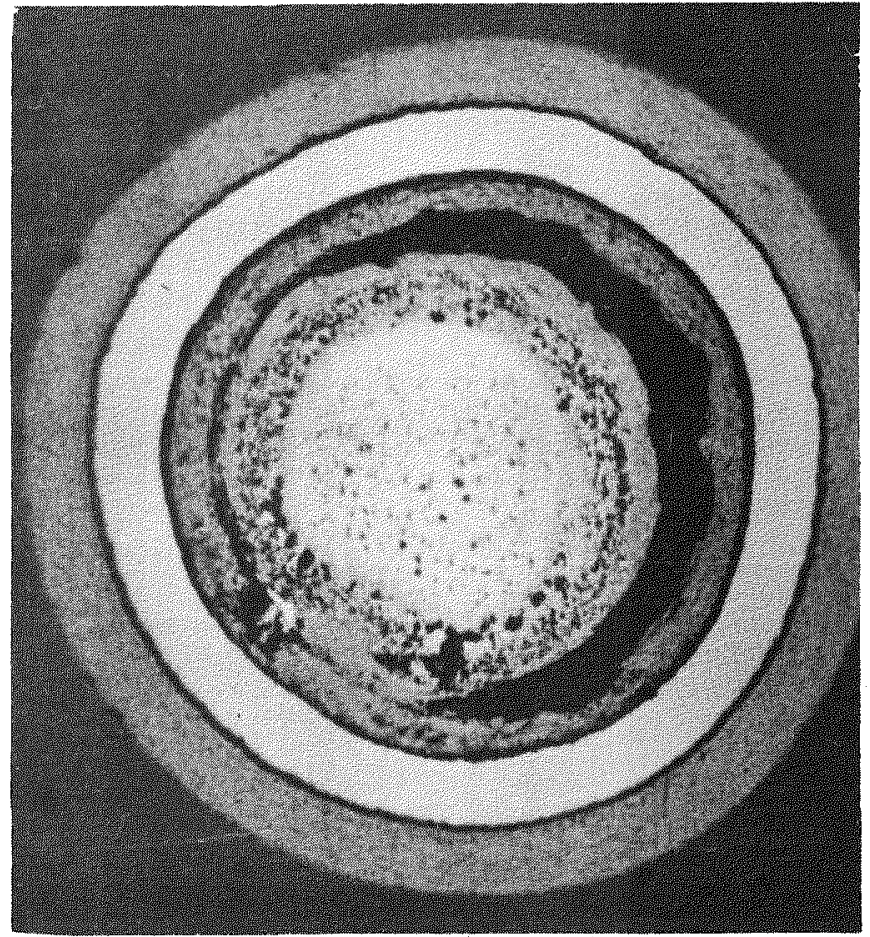

M386-202

(c)

2300x

Fig. 9.10. Photographs of UC 2 TRISO-HTI coated particle batch 3516-35: (a) before irradiation; (b) and (c) after irradiation in capsule $\mathrm{P} 13 \mathrm{~L}$ to $7.8 \times 10^{21} \mathrm{n} / \mathrm{cm}^{2}$ at approximately $1350^{\circ} \mathrm{C}$ to burnups of approximately $75 \%$ FIMA 

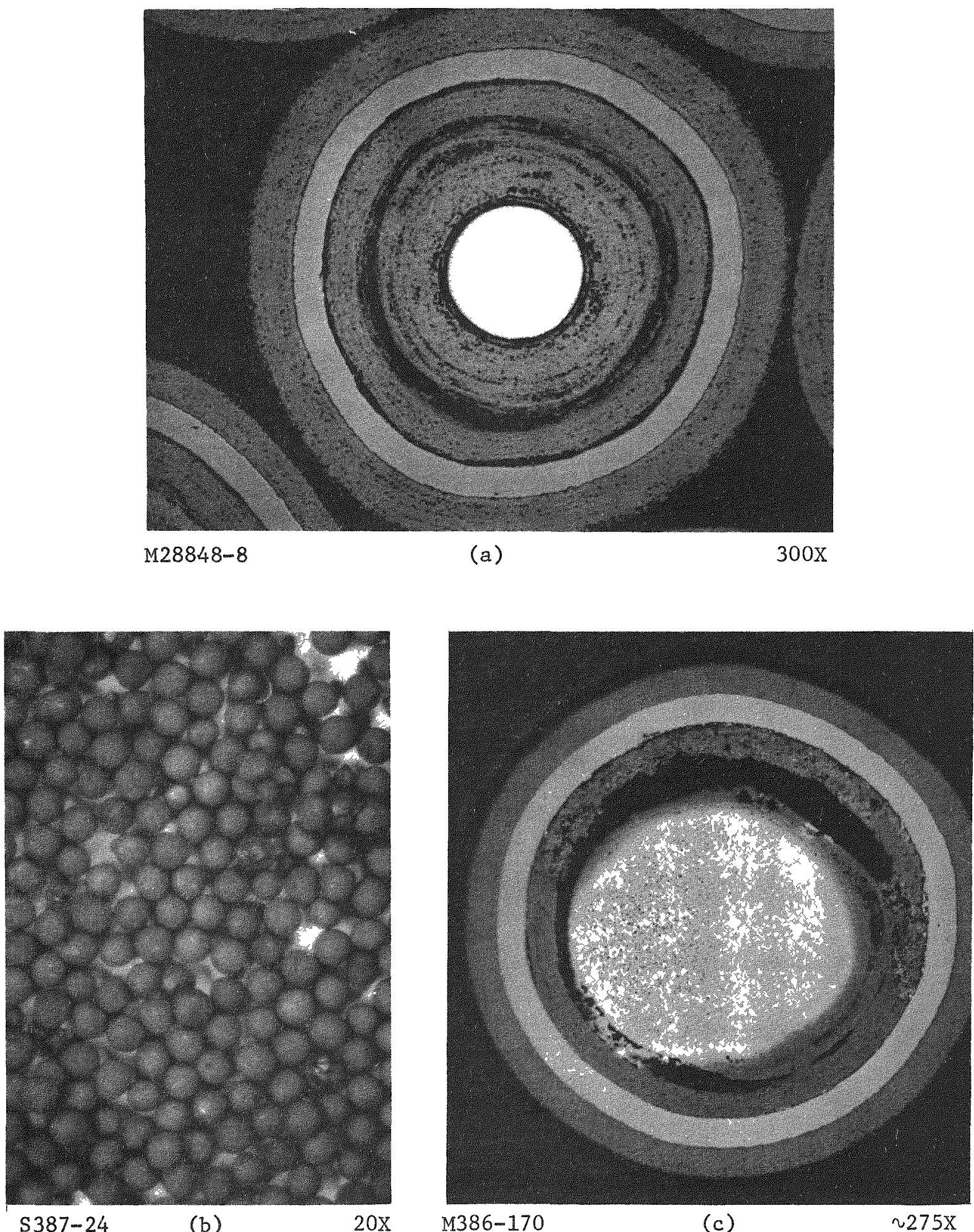

M386-170

(c)

$\sim 275 x$

Fig. 9.11. Photographs of $\mathrm{UC}_{2}$ TRISO-LTI coated particle batch 4413-7: (a) before irradiation; (b) and (c) after irradiation in capsule P13L to $7.8 \times 10^{21} \mathrm{n} / \mathrm{cm}^{2}$ at approximate $1 \mathrm{y} 1350^{\circ} \mathrm{C}$ to burnups of approximately $75 \%$ FIMA 

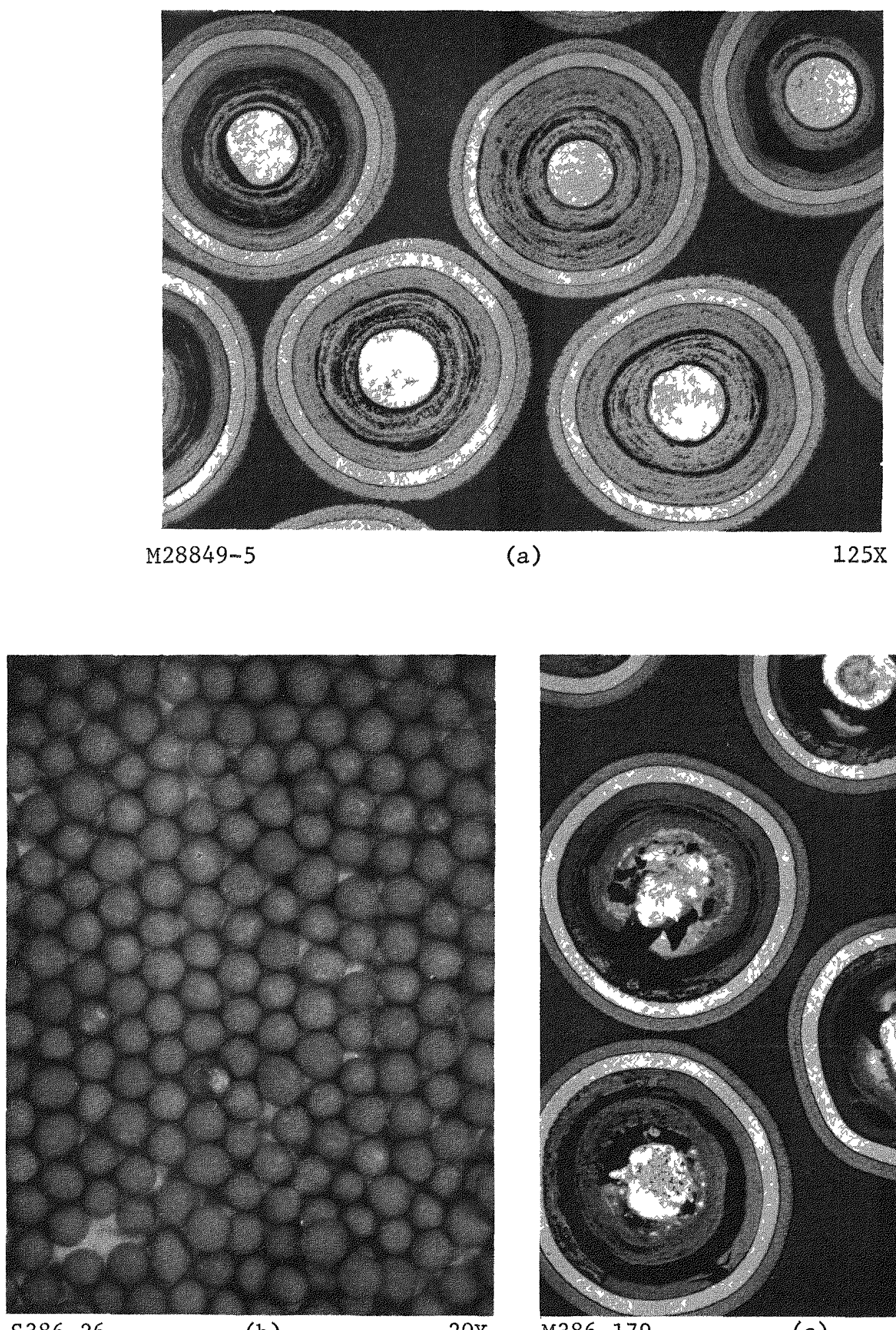

S386-26

(b)

20x

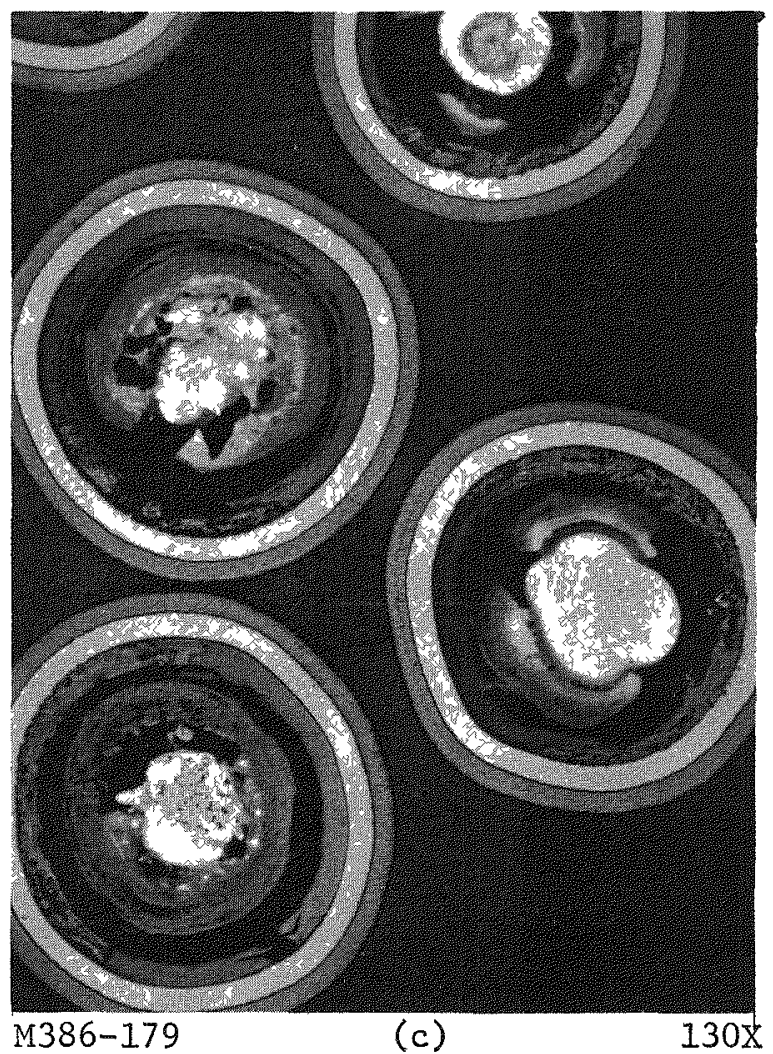

Fig. 9.12. Photographs of $\mathrm{UC}_{2}$ TRISO-LTI coated particle batch 4413-21:

(a) before irradiation; (b) and (c) after irradiation in capsule P13L to $7.8 \times 10^{21} \mathrm{n} / \mathrm{cm}^{2}$ at approximately $1200^{\circ} \mathrm{C}$ to burnups of approximately $75 \%$ FIMA 


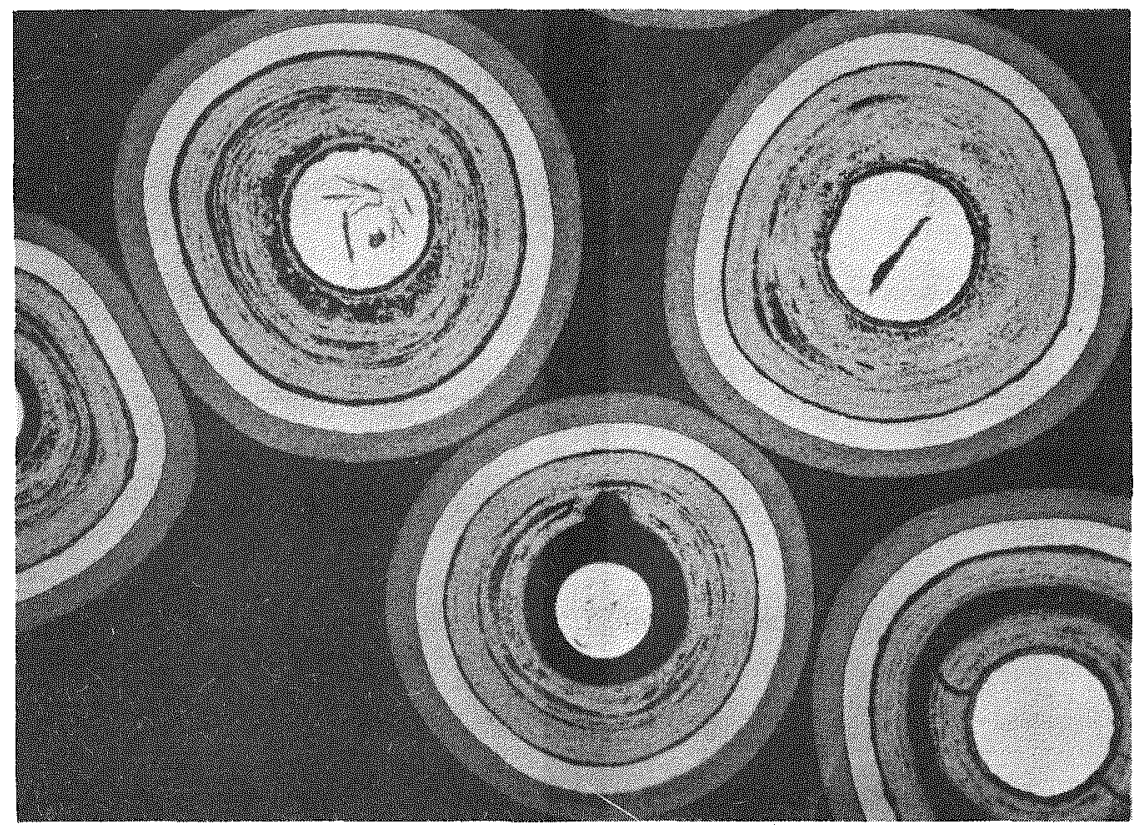

M28837-4

(a)

$150 \mathrm{X}$
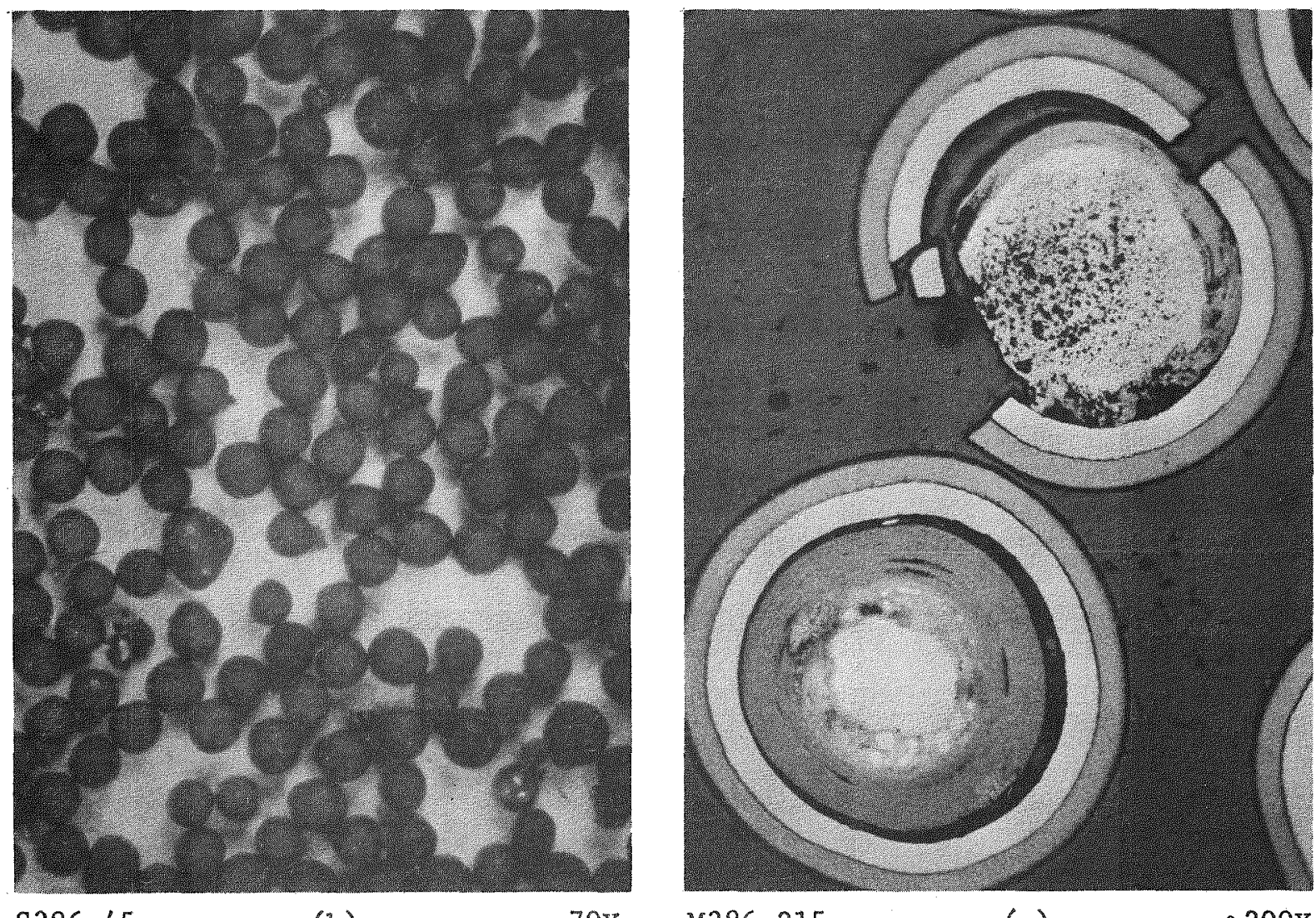

S386-45

(b)

$70 x$

(c)

2 $200 x$

Fig. 9.13. Photographs of $\mathrm{UC}_{2}$ TRISO-HTI coated particle batch 3516-33: (a) before irradiation; (b) and (c) after irradiation in capsule $\mathrm{P} 13 \mathrm{~L}$ to $7.8 \times 10^{21} \mathrm{n} / \mathrm{cm}^{2}$ at approximately $1275^{\circ} \mathrm{C}$ to burnups of approximately $75 \%$ FIMA 

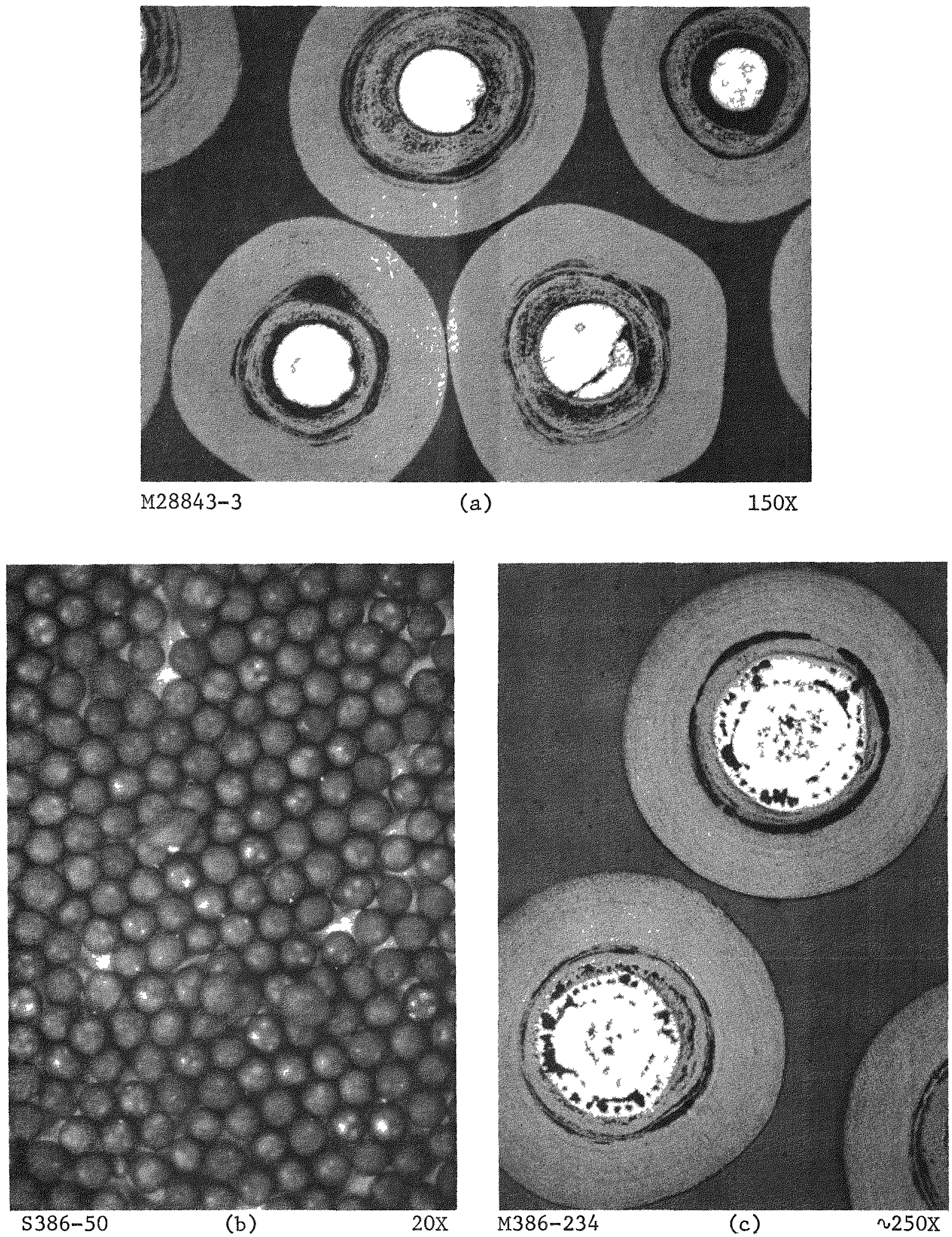

Fig. 9.14. Photographs of $\mathrm{UC}_{2}$ BISO-LTI coated particle batch 4403-81: (a) before irradiation; (b) and (c) after irradiation in capsule $\mathrm{P} 13 \mathrm{~L}$ to $7.8 \times 10^{21} \mathrm{n} / \mathrm{cm}^{2}$ at approximately $1225^{\circ} \mathrm{C}$ to burnups of approximately $75 \%$ FIMA 

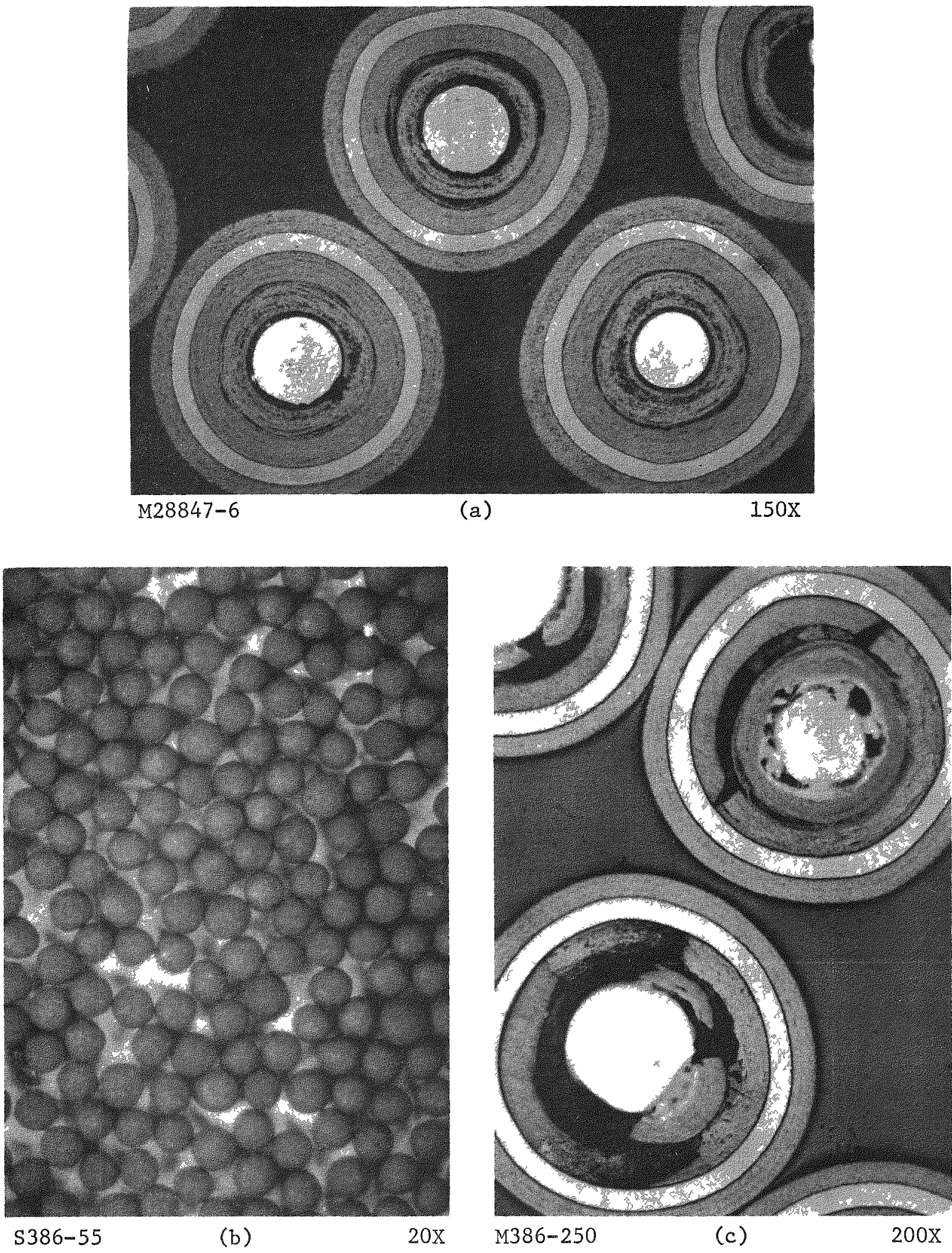

Fig. 9.15. Photographs of UC 2 TRISO-LTI coated particle batch 4413-5: (a) before irradiation; (b) and (c) after irradiation in capsule $\mathrm{P} 13 \mathrm{~L}$ to $7.8 \times 10^{21} \mathrm{n} / \mathrm{cm}^{2}$ at approximately $1250^{\circ} \mathrm{C}$ to burnups of approximately $75 \%$ FIMA 

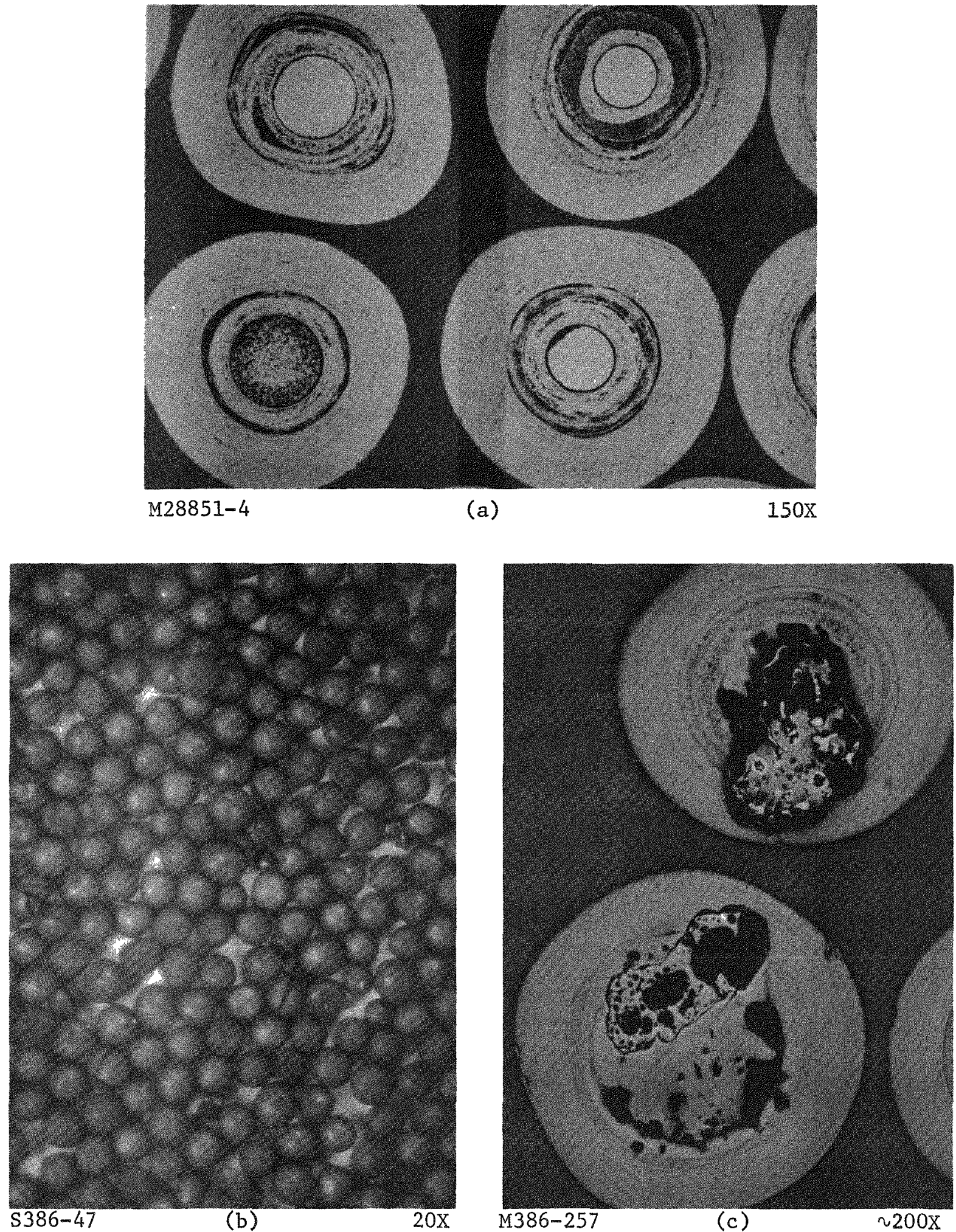

Fig. 9.16. Photographs of $\mathrm{UO}_{2}$ BISO-LTI coated particle batch 4413-35:

(a) before irradiation; (b) and (c) after irradiation in capsule $\mathrm{P} 13 \mathrm{~L}$ to $7.8 \times 10^{21} \mathrm{n} / \mathrm{cm}^{2}$ at approximately $1275^{\circ} \mathrm{C}$ to burnups of approximately $75 \%$ FIMA 

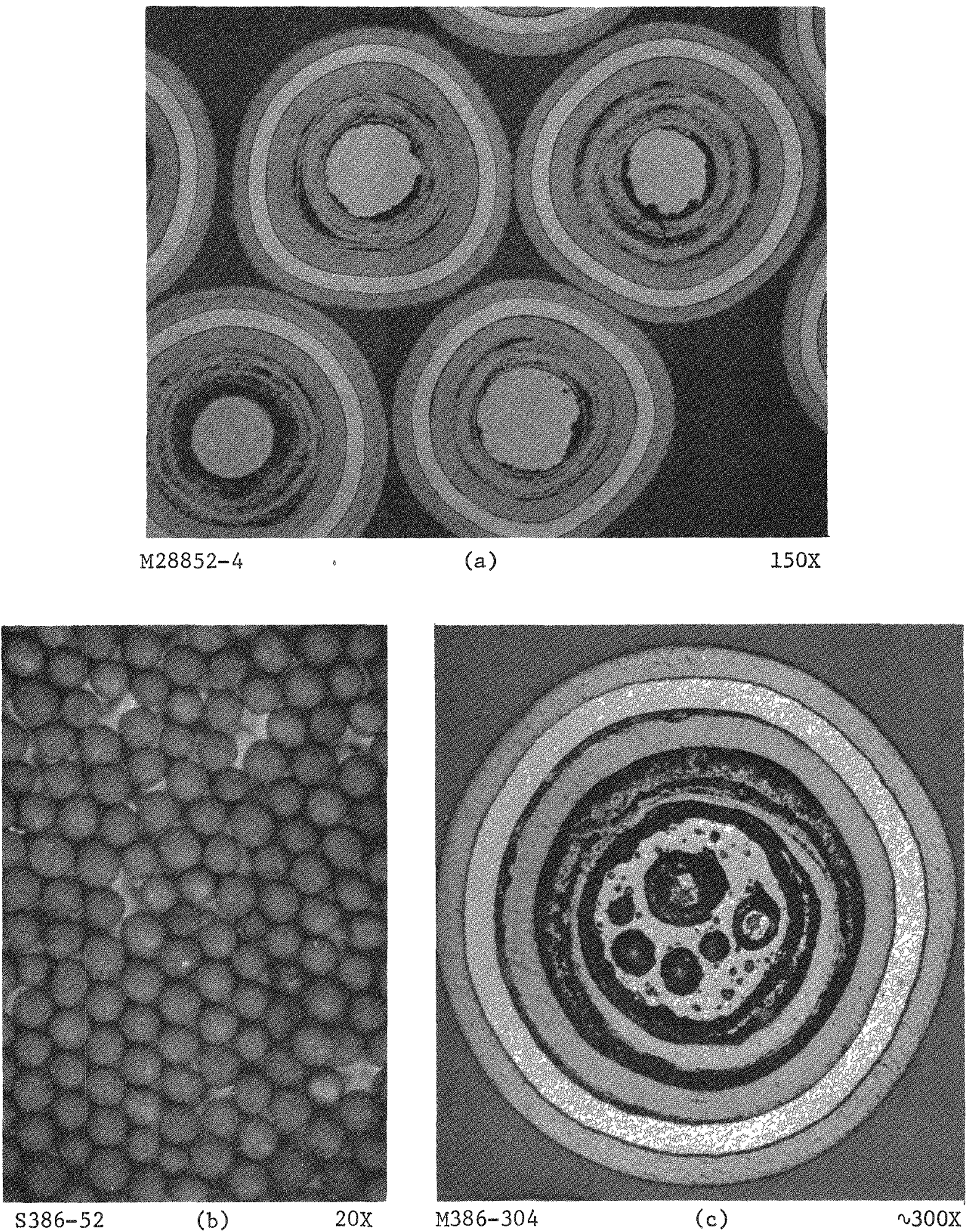

Fig. 9.17. Photographs of $\mathrm{UO}_{2}$ TRISO-LTI coated particle batch 4413-67: (a) before irradiation; (b) and (c) after irradiation in capsule $\mathrm{P} 13 \mathrm{~L}$ to $7.8 \times 10^{21} \mathrm{n} / \mathrm{cm}^{2}$ at approximately $1275^{\circ} \mathrm{C}$ to burnups of approximately $75 \%$ FIMA 

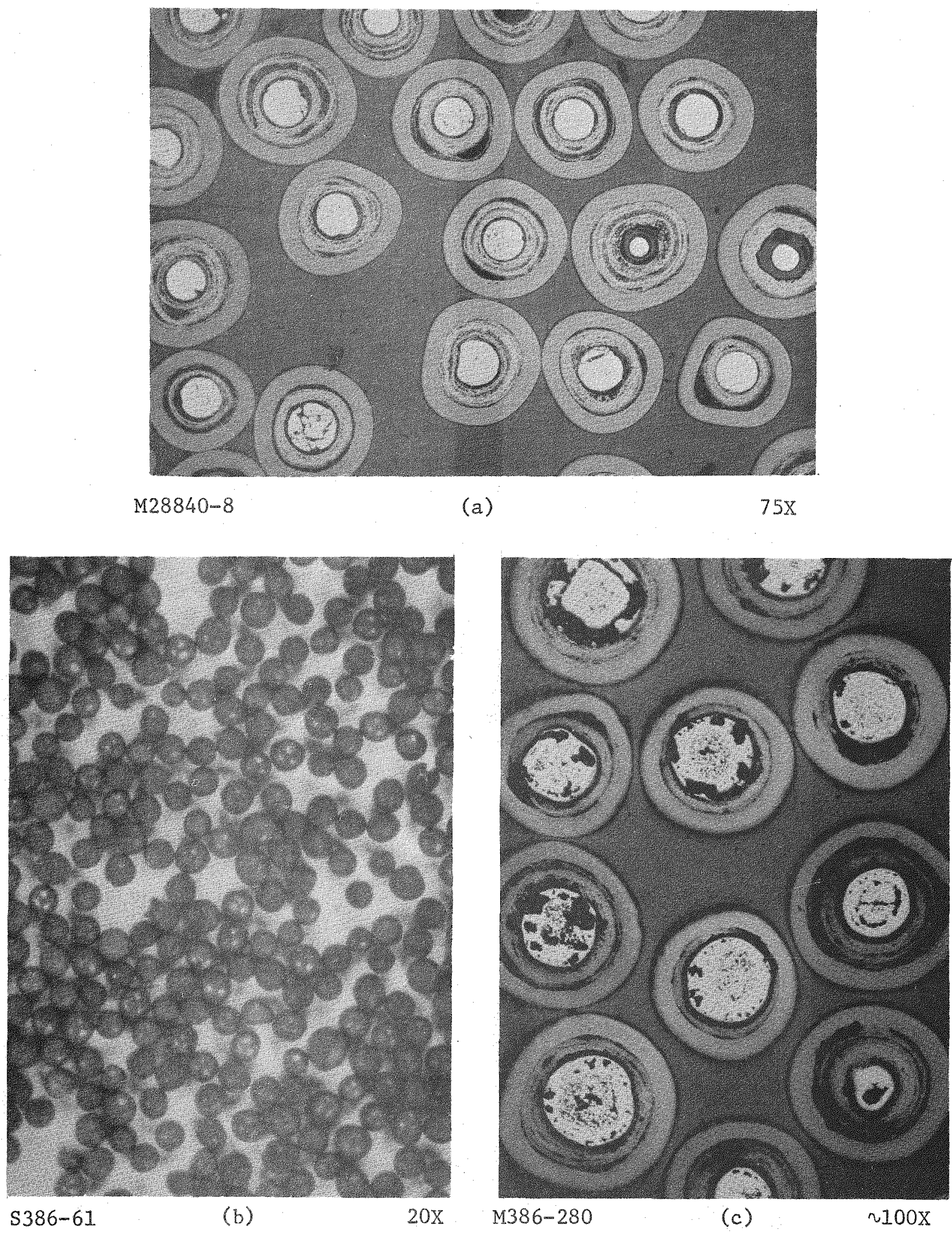

Fig. 9.18. Photographs of $\mathrm{UC}_{2}$ BISO-HTI coated particle batch 3516-47: (a) before irradiation; (b) and (c) after irradiation in capsule

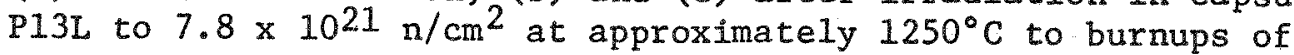
approximately $75 \%$ FIMA 

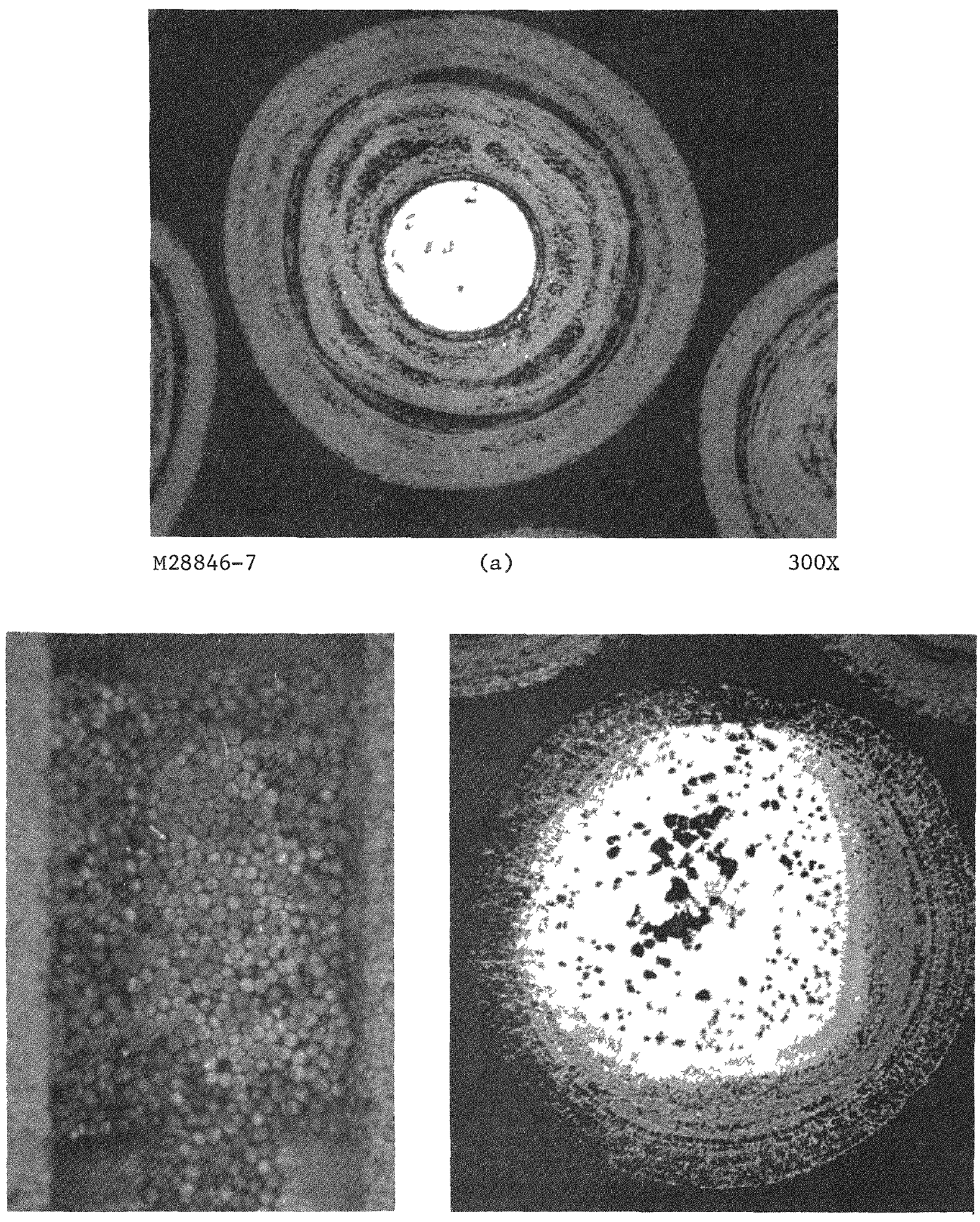

S386-34

(b)

$10 \mathrm{X}$

M386-330

(c)

$325 \mathrm{x}$

Fig. 9. 19. Photographs of $\mathrm{UC}_{2}$ BISO-LTI coated particle batch 4403-145:

(a) before irradiation; (b) and (c) after irradiation in capsule P13L to $7.2 \times 10^{21} \mathrm{n} / \mathrm{cm}^{2}$ at approximately $1350^{\circ} \mathrm{C}$ to burnups of approximately $75 \%$ FIMA 

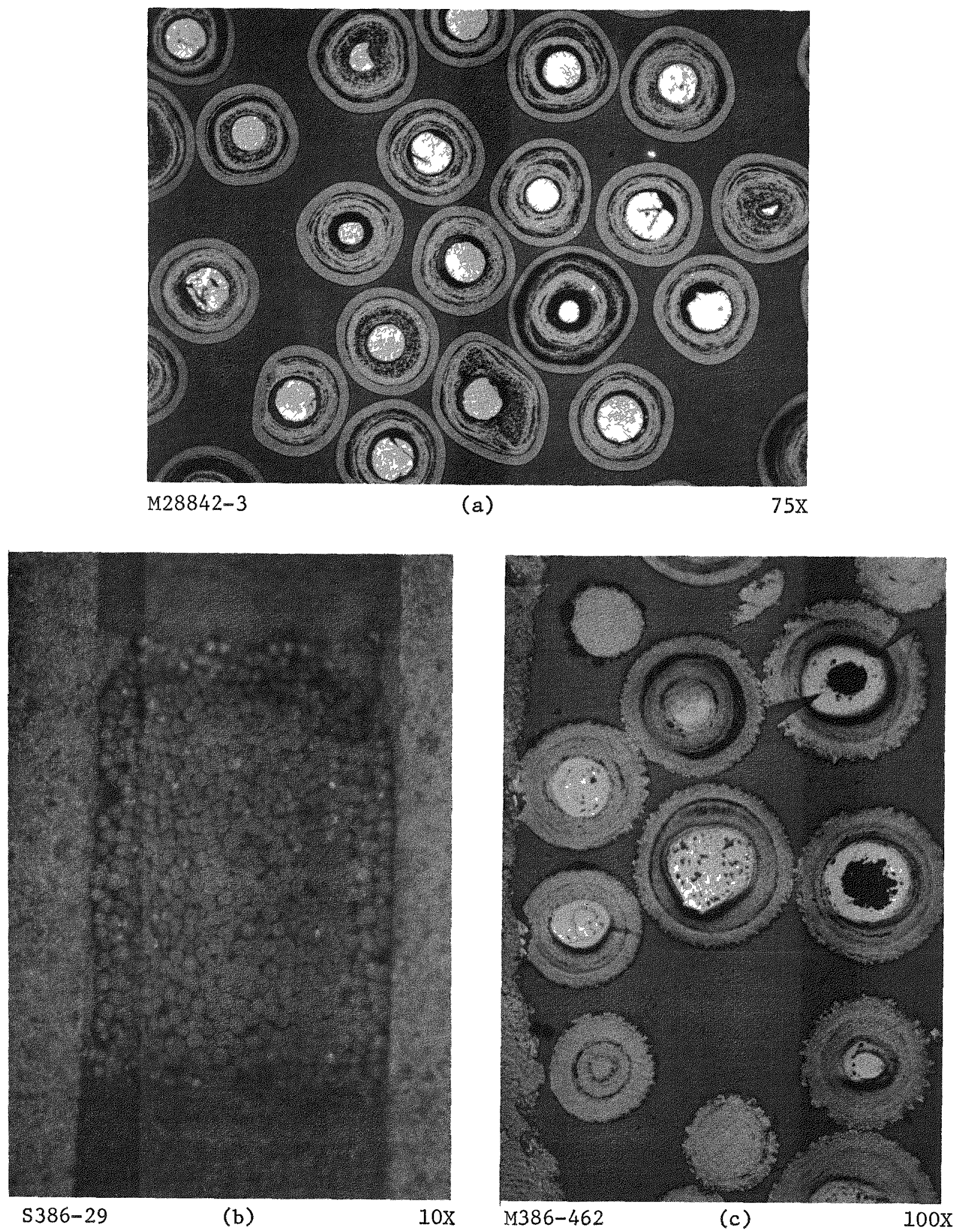

Fig. 9.20. Photographs of $\mathrm{UC}_{2}$ BISO-HTI coated particle batch 3516-57: (a) before irradiation; (b) and (c) after irradiation in capsule P13L to $7.2 \times 10^{21} \mathrm{n} / \mathrm{cm}^{2}$ at approximately $1350^{\circ} \mathrm{C}$ to burnups of approximately $75 \%$ FIMA 

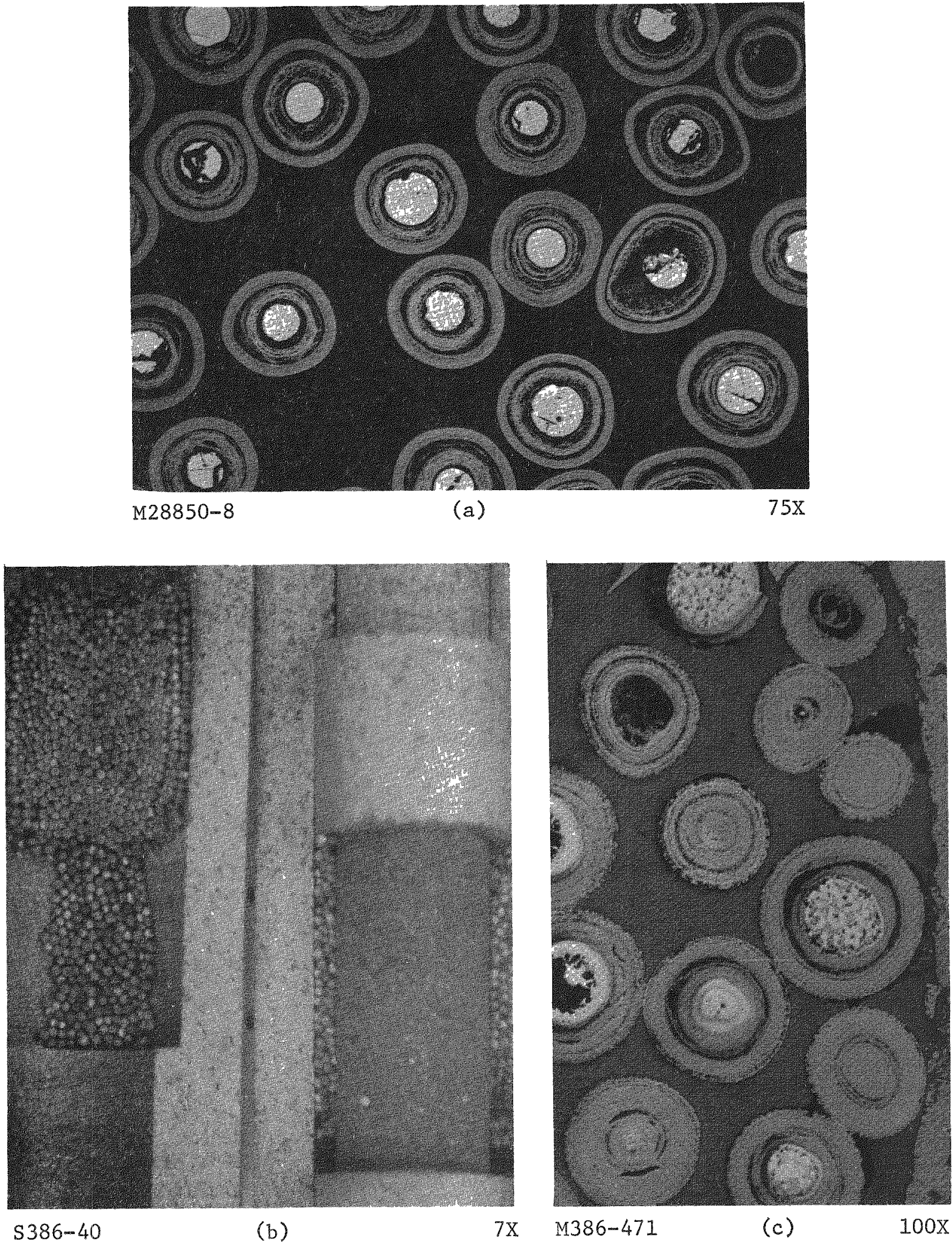

$5386-40$

(b)

$7 \mathrm{X} \quad \mathrm{M} 386-471$

(c)

$100 x$

Fig. 9.21. Photographs of UC 2 BISO-LTI coated particle batch 4413-29: (a) before irradiation; (b) and (c) after irradiation in capsule P13L to $7.2 \times 10^{21} \mathrm{n} / \mathrm{cm}^{2}$ at approximately $1325^{\circ} \mathrm{C}$ to burnups of approximately $75 \%$ FIMA 

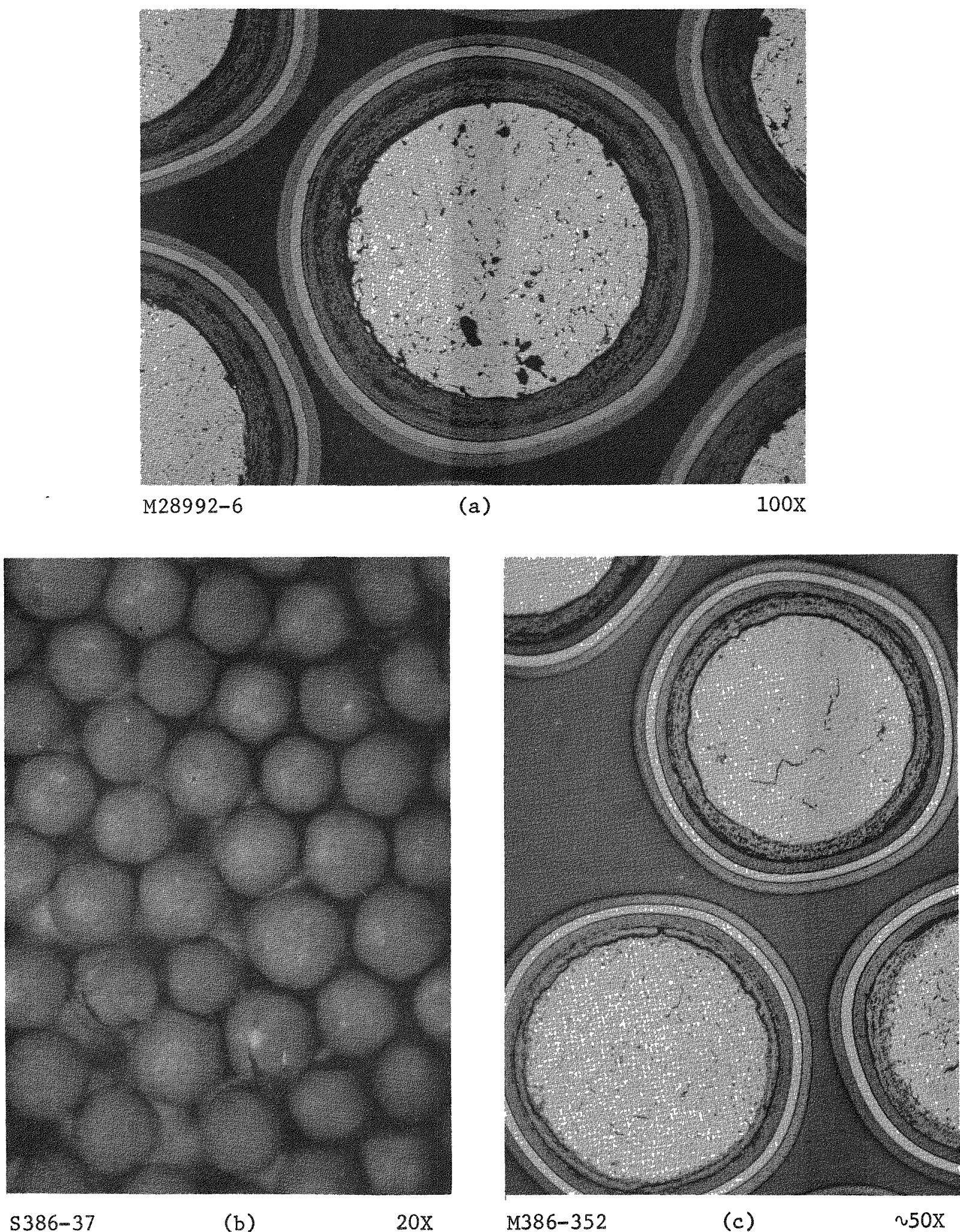

S $386-37$

(b)

$20 x$

(c)

ఒ50x

Fig. 9.22. Photographs of $\mathrm{ThC}_{2}$ TRISO-LTI coated particle batch 4423-67: (a) before irradiation; (b) and (c) after irradiation in capsule $\mathrm{P} 13 \mathrm{~L}$ to $7.2 \times 10^{21} \mathrm{n} / \mathrm{cm}^{2}$ at approximately $1225^{\circ} \mathrm{C}$ to burnups of approximately $7 \%$ FIMA 


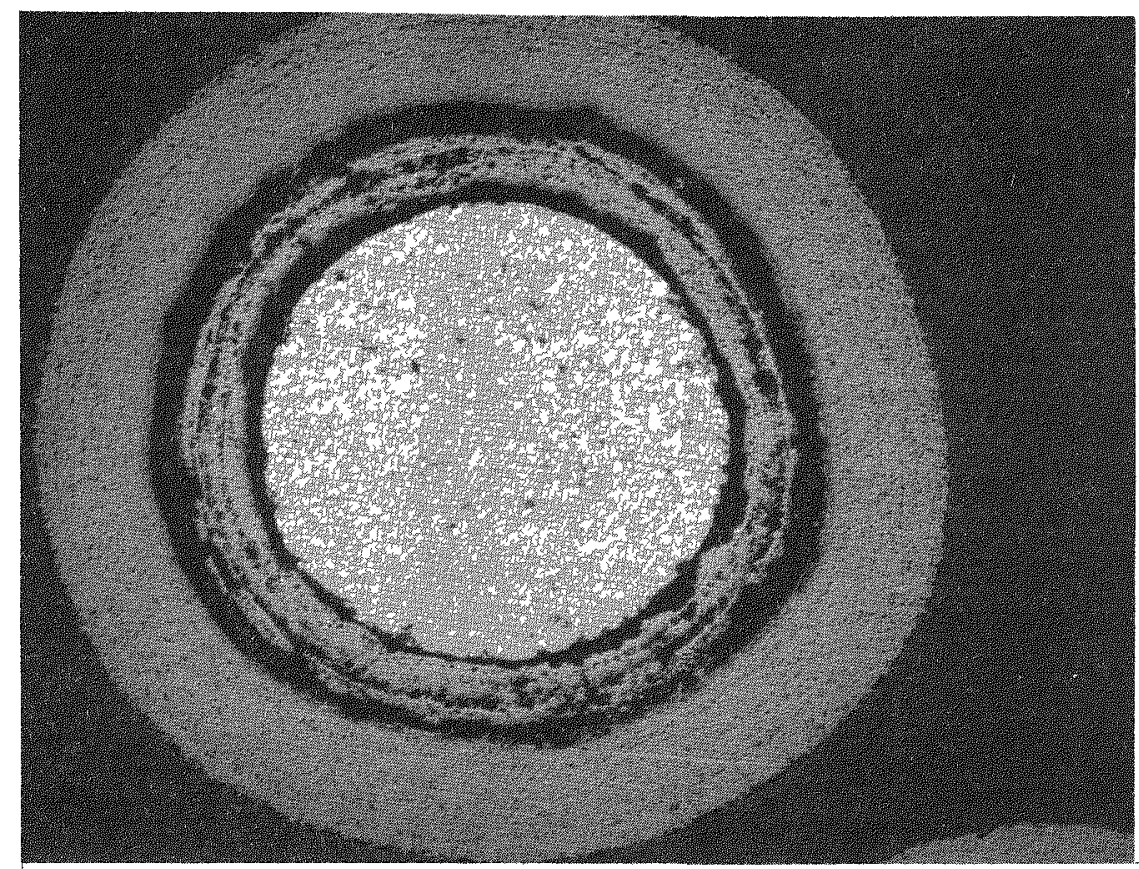

M29316-2

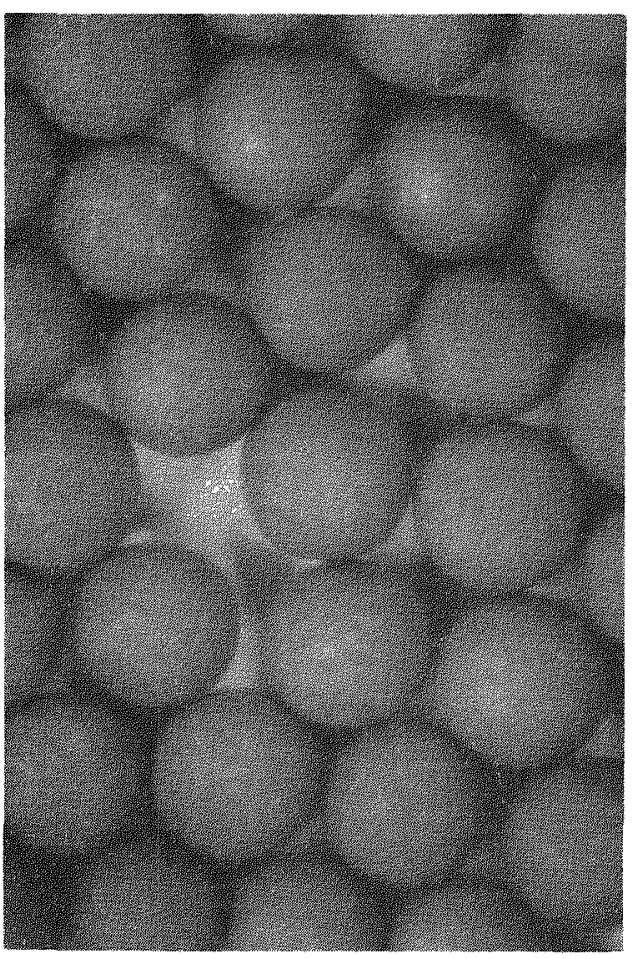

S386-32

(b)

$20 x$

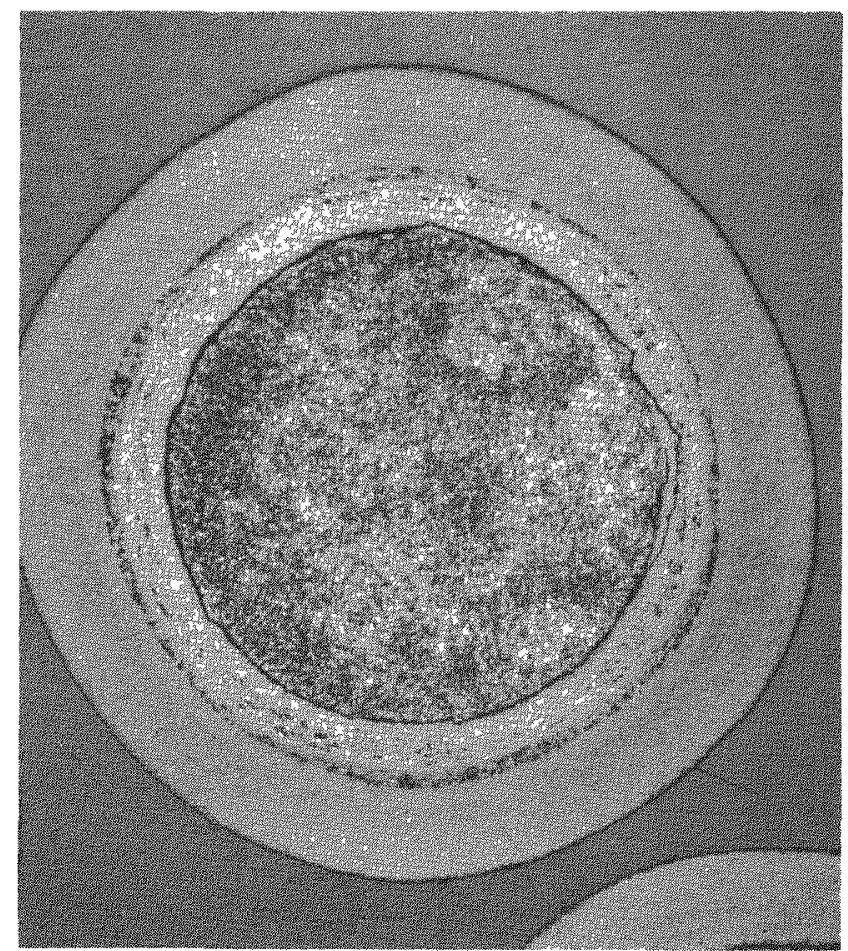

(c)

100X

Fig. 9.23. Photographs of $\mathrm{ThC}_{2}$ BISO-LTI coated particle batch 4423-89:

(a) before irradiation; (b) and (c) after irradiation in capsule P13L to $7.2 \times 10^{21} \mathrm{n} / \mathrm{cm}^{2}$ at $1175^{\circ} \mathrm{C}$ to burnups of approximately 7\% FIMA 

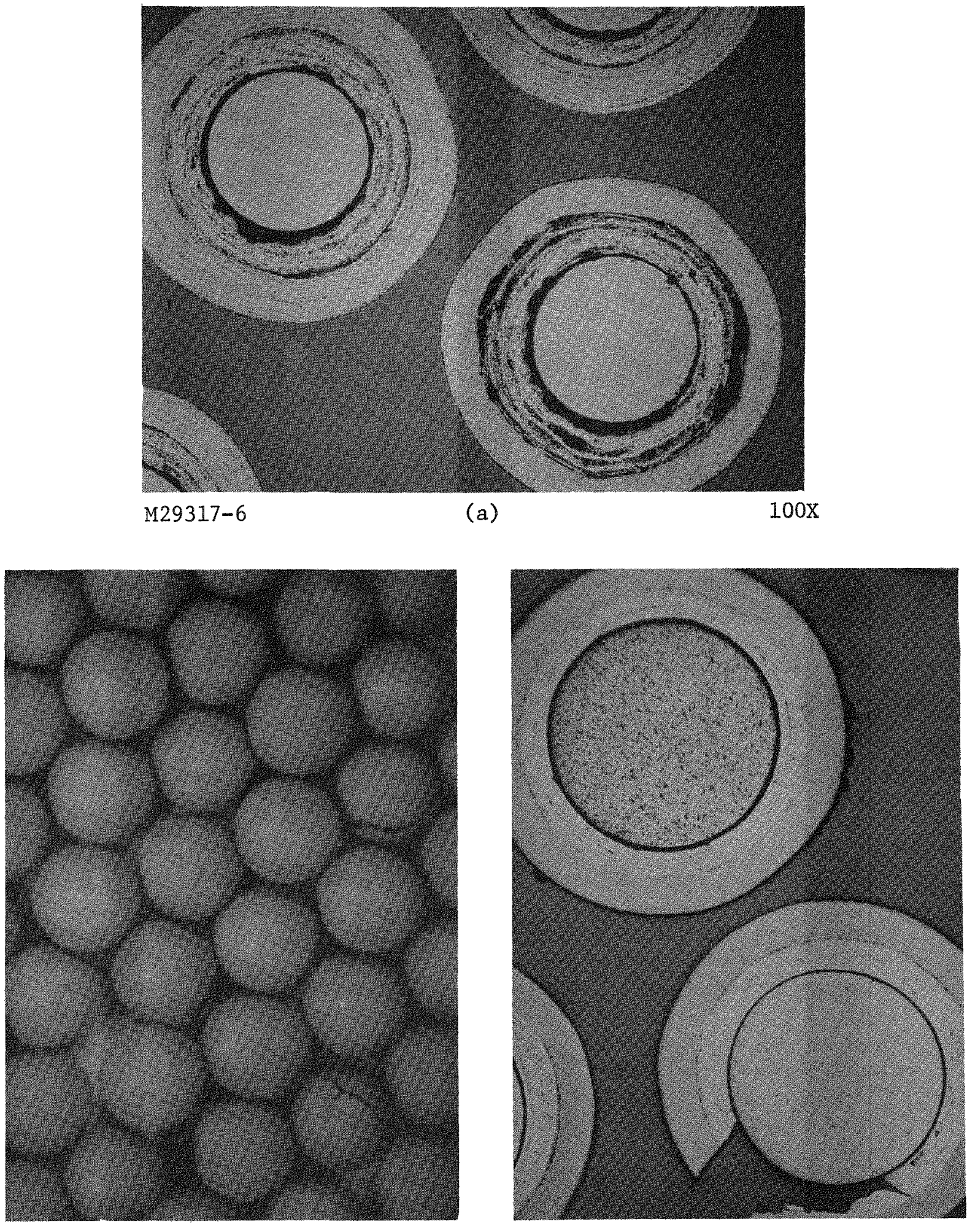

S386-39

(b)

$20 \mathrm{x}$

M386-363

(c)

$100 \mathrm{x}$

Fig. 9.24. Photographs of $\mathrm{ThO}_{2}$ BISO-LTI coated particle batch 4413-75: (a) before irradiation; (b) and (c) after irradiation in capsule P13L to $7.2 \times 10^{21} \mathrm{n} / \mathrm{cm}^{2}$ at $1325^{\circ} \mathrm{C}$ to burnups of approximately $7 \%$ FIMA 

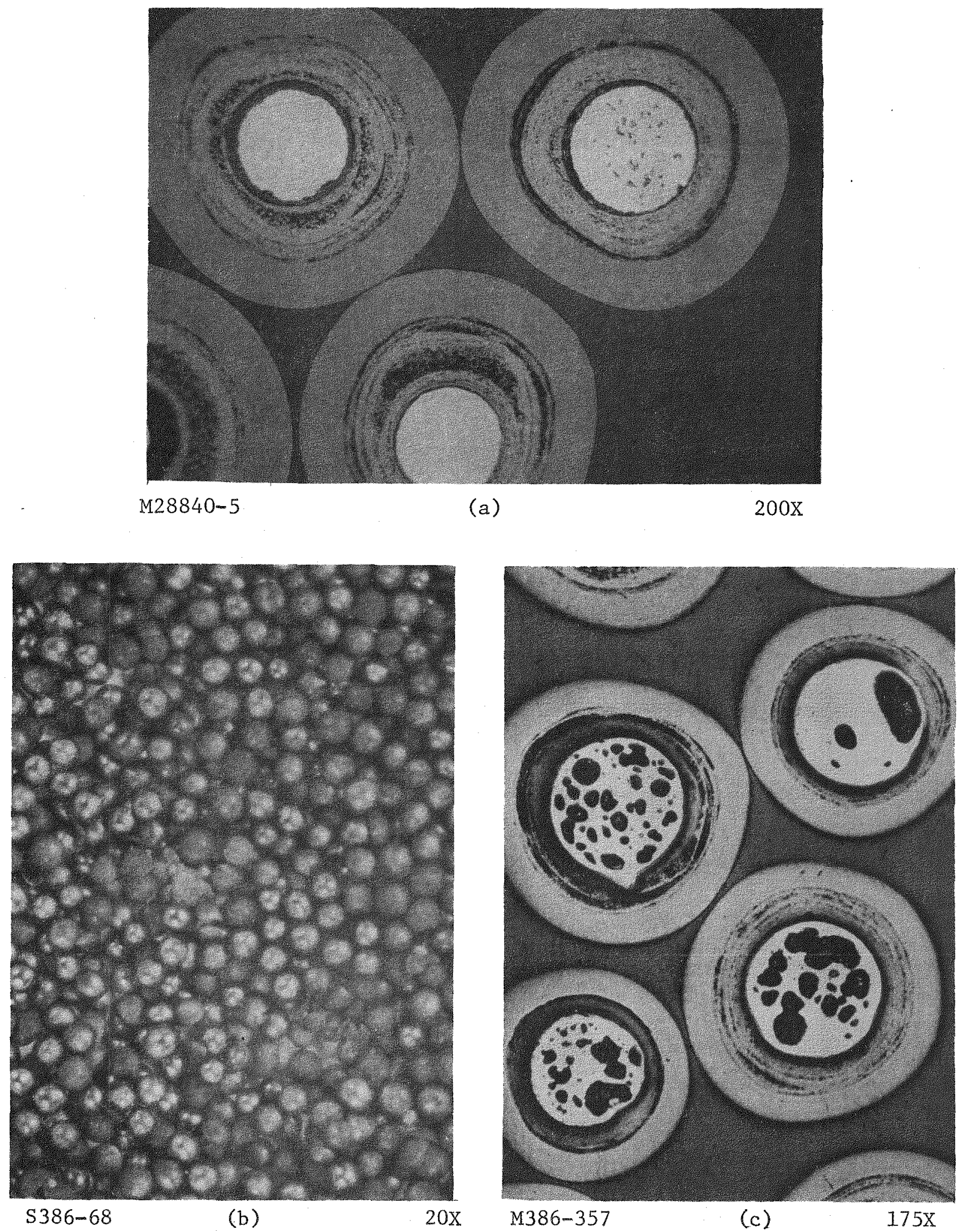

Fig. 9.25. Photographs of $\mathrm{UC}_{2}$ BISO-HTI coated particle batch 3516-47: (a) before irradiation; (b) and (c) after irradiation in capsule P13L to $5.8 \times 10^{21} \mathrm{n} / \mathrm{cm}^{2}$ at $875^{\circ} \mathrm{C}$ to burnups of approximately $60 \%$ FIMA 

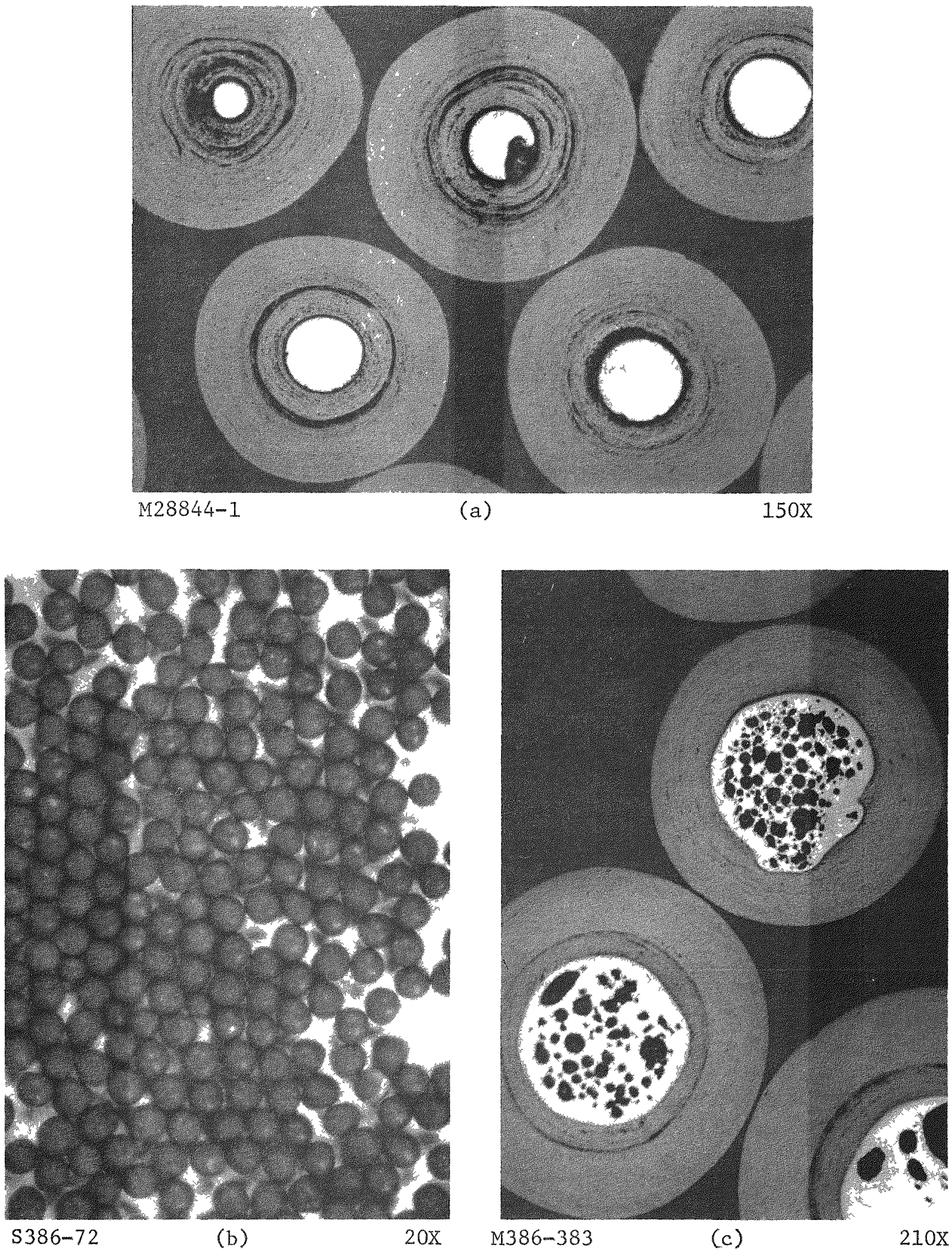

Fig. 9.26. Photographs of $\mathrm{UC}_{2}$ BISO-LTI coated particle batch 4403-113: (a) before irradiation; (b) and (c) after irradiation in capsule $\mathrm{P} 13 \mathrm{~L}$ to $5.8 \times 10^{21} \mathrm{n} / \mathrm{cm}^{2}$ at $850^{\circ} \mathrm{C}$ to burnups of approximately $60 \%$ FIMA 

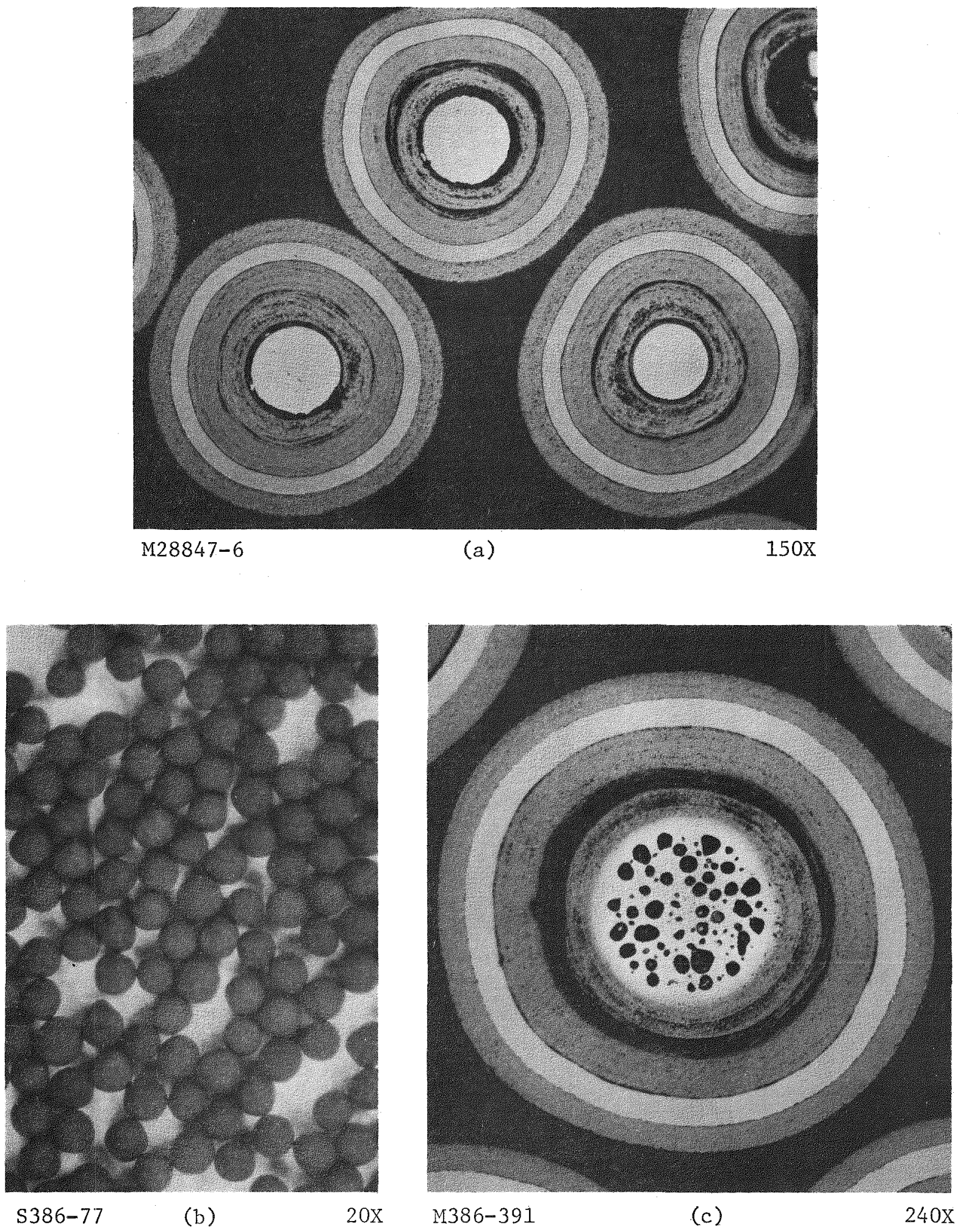

Fig. 9.27. Photographs of $\mathrm{UC}_{2}$ TRISO-LTI coated particle batch 4413-5: (a) before irradiation; (b) and (c) after irradiation in capsule P13L to $5.8 \times 10^{21} \mathrm{n} / \mathrm{cm}^{2}$ at $850^{\circ} \mathrm{C}$ to burnups of approximately $60 \%$ FIMA 

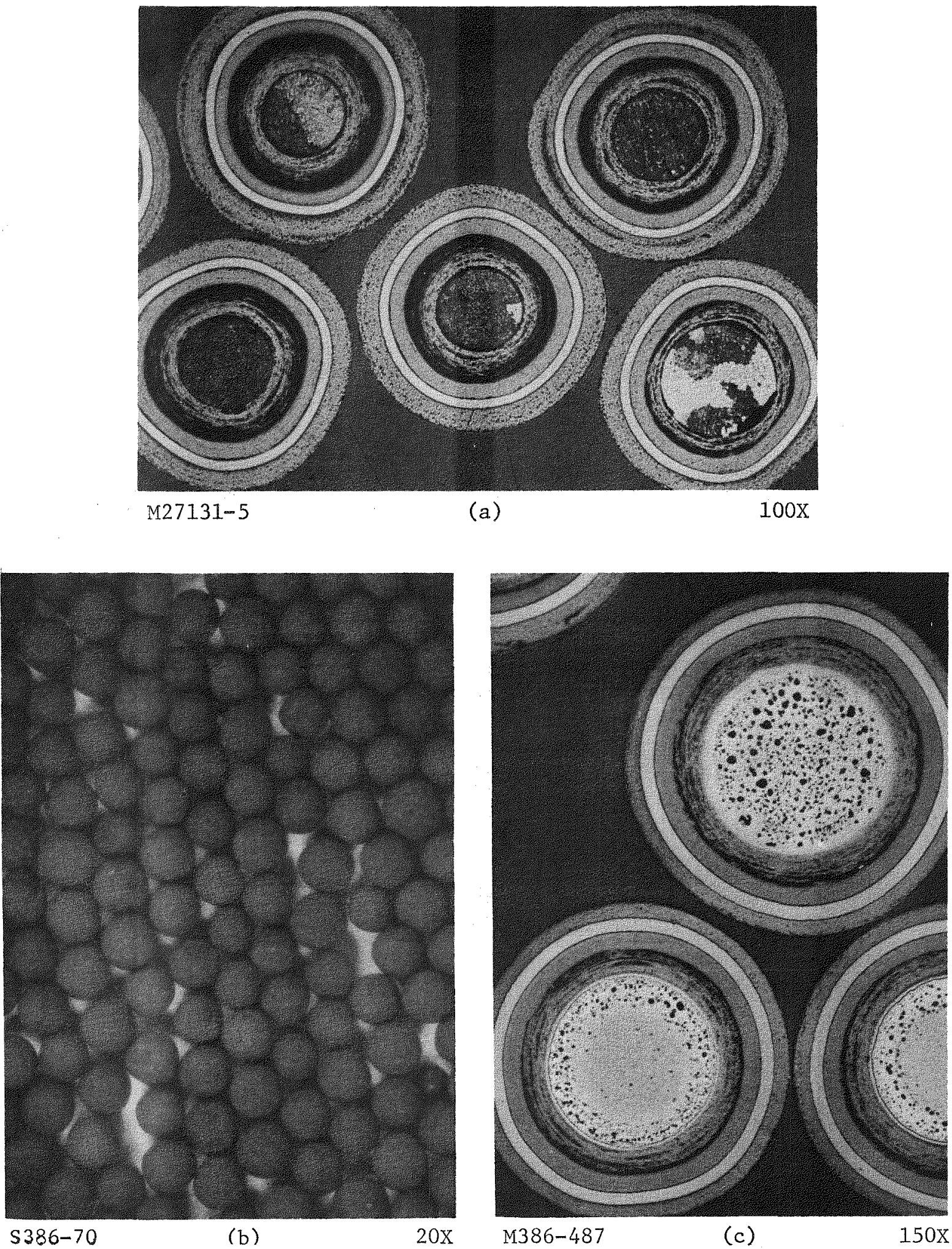

Fig. 9.28. Photographs of $(\mathrm{Th}, \mathrm{U}) \mathrm{C}_{2}$ TRISO-LTI coated particle batch 4263-75: (a) before irradiation; (b) and (c) after irradiation in capsule P13L to $5.8 \times 10^{21} \mathrm{n} / \mathrm{cm}^{2}$ at $925^{\circ} \mathrm{C}$ to burnups of approximately $20 \%$ FIMA 

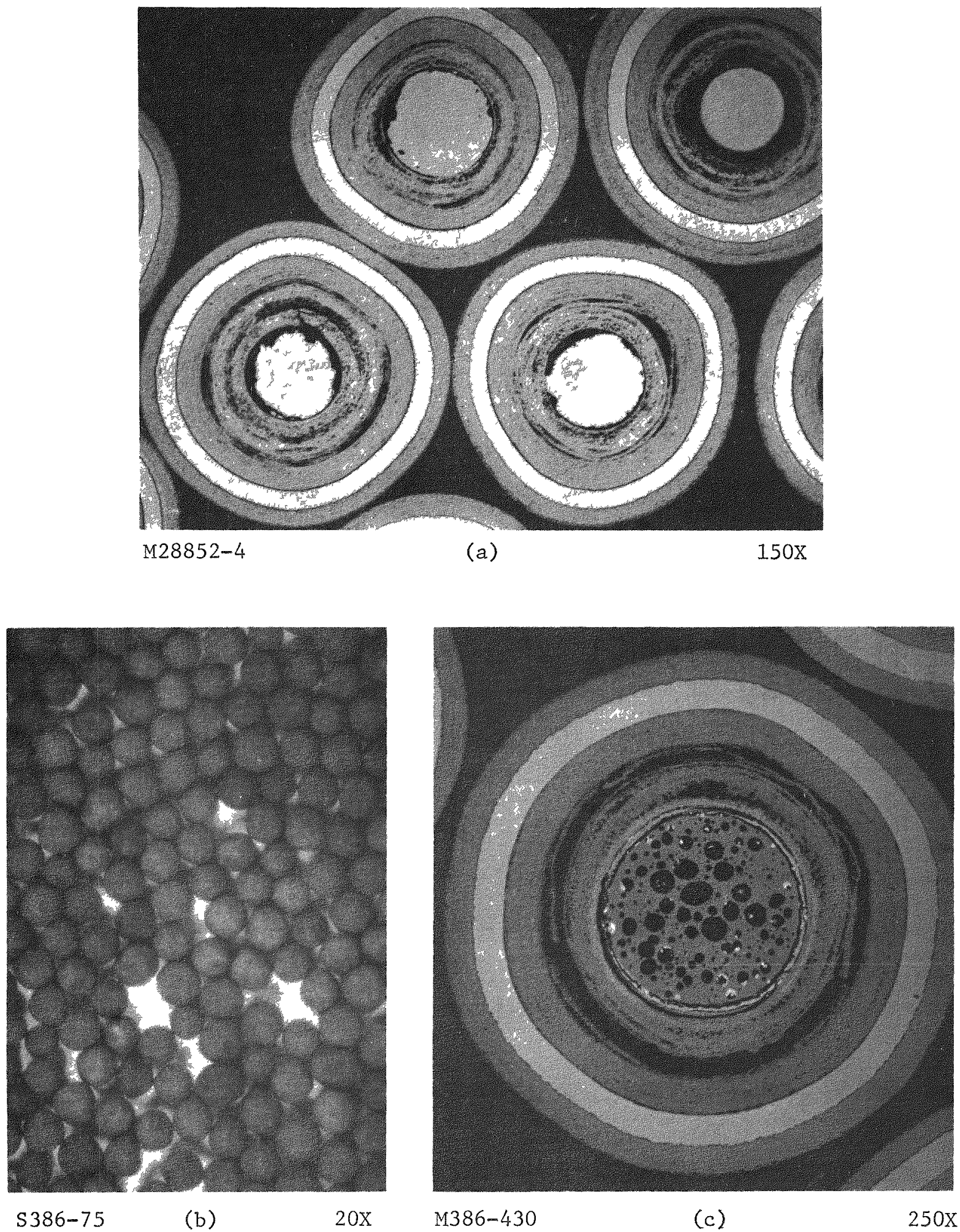

Fig. 9.29. Photographs of $\mathrm{UO}_{2}$ TRISO-LTI coated particle batch 4413-67: (a) before irradiation; (b) and (c) after irradiation in capsule P13L to $5.8 \times 10^{21} \mathrm{n} / \mathrm{cm}^{2}$ at $875^{\circ} \mathrm{C}$ to burnups of approximately $60 \%$ FIMA 

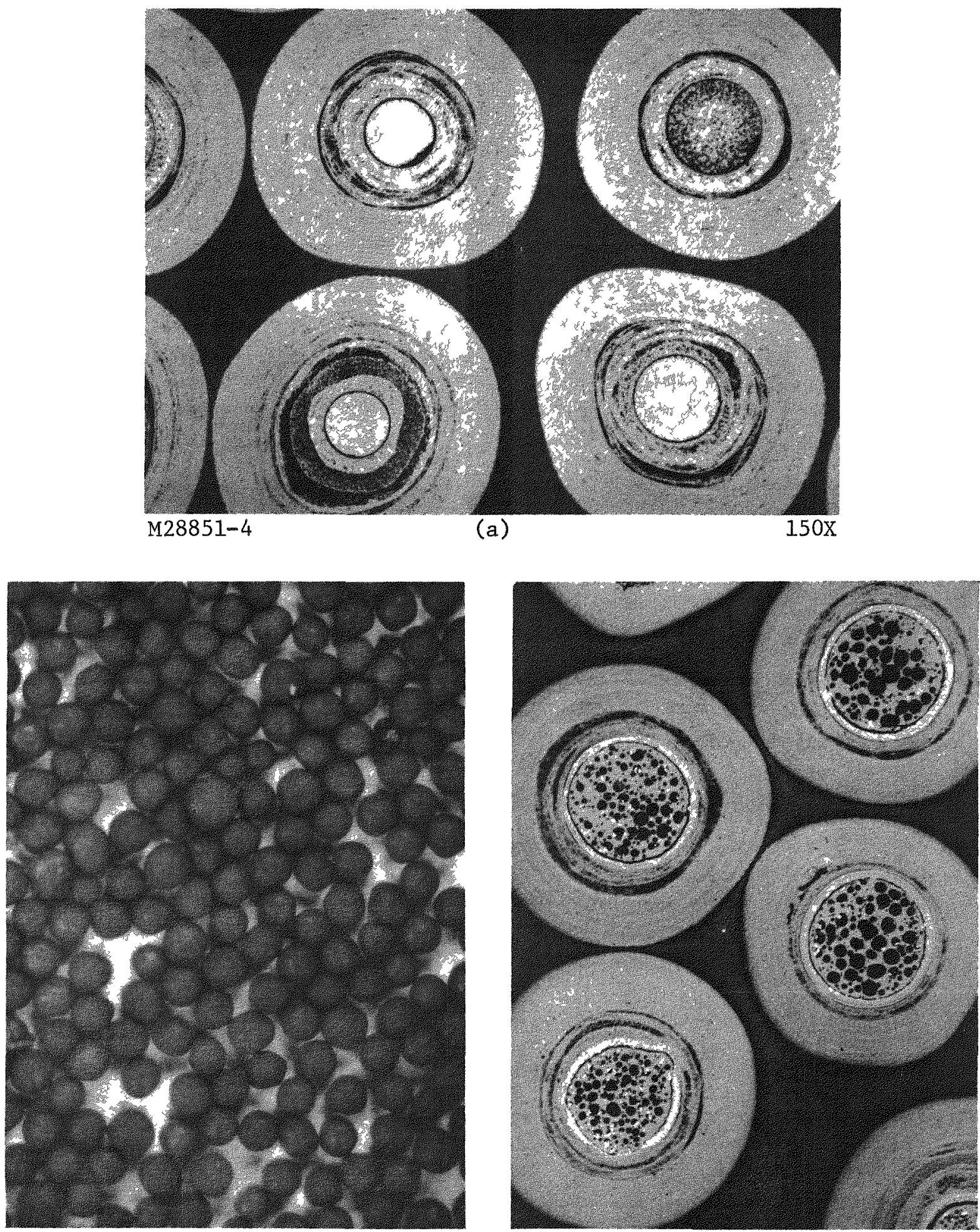

S386-79

(b)

$20 \mathrm{x}$

M386-403

(c)

$135 \mathrm{X}$

Fig. 9.30. Photographs of $\mathrm{UO}_{2}$ BISO-LTI coated particle batch 4413-35:

(a) before irradiation; (b) and (c) after irradiation in capsule P13L to $5.8 \times 10^{21} \mathrm{n} / \mathrm{cm}^{2}$ at $850^{\circ} \mathrm{C}$ to burnups of approximately $60 \%$ FIMA 
past results. At $1300^{\circ}$ and $900^{\circ} \mathrm{C}$ the majority of the particle failures resulted from the "cascade" effect, where a small number of exposed kernels caused extensive failure of surrounding outer PyC layers. It appears that this would not be a problem in fuel rods.

Both BISO-UC 2 and BISO-UO $\mathrm{U}_{2}$ particles exhibited poor performance at $1500^{\circ} \mathrm{C}$. Extensive fuel and metallic fission-product migration occurred resulting in high failure of the isotropic PyC layer. BISO-UC 2 samples looked somewhat better at $900^{\circ} \mathrm{C}$ and $1300^{\circ} \mathrm{C}$, but some particles were observed sticking to the thimble walls, especially when the coatings were thin. This latter observation shows that a considerable amount of metallic fission products or fuel is escaping from BISO particles. The $\mathrm{UO}_{2}-\mathrm{BISO}$ batch irradiated at $1300^{\circ} \mathrm{C}$ looked worse than its $1500^{\circ} \mathrm{C}$ companion (as did the " TRISO-UO 2 sample) and considerable kernel migration was noted. The "cascade" effect was the greatest cause of failures at $900^{\circ} \mathrm{C}$, again similar to the results obtained with the TRISO-UO $\mathrm{UO}_{2}$ particles.

The standard $(\mathrm{Th}, \mathrm{U}) \mathrm{C}_{2}$ sample exhibited the best performance; however, the importance of the "amoeba" effect was amplified from the results of the $1500^{\circ} \mathrm{C}$ test where all the failures resulted from kernel migration.

\section{Capsule P13M}

Construction of capsule P13M is nearing completion. The two fuel rod cells and one coated particle cell have been loaded, and the thermocouple calibration cells are being assembled. The capsule is scheduled to begin irradiation in the ETR (II3 core position) in cycle $110 \mathrm{C}$ by early March 1971.

Capsule P13M is the second ful1-exposure test of candidate large HTGR initial and recycle core fuel particles, and the first test of such particles made in production equipment; it is also the first test of large HTGR type fuel rods to full reactor design conditions. Some of the particle samples are duplicates of those now being tested or to be tested in Phase I and Phase II Peach Bottom test elements, and P13M will provide full-exposure data on these important materials. 
Capsule P13M contains two fuel rod cells, each holding six rods; one will operate at $1000^{\circ} \mathrm{C}$ to $8 \times 10^{21} \mathrm{n} / \mathrm{cm}^{2}$ and the other at $1350^{\circ} \mathrm{C}$ to 4 to $5 \times 10^{21}$ $\mathrm{n} / \mathrm{cm}^{2}$, as shown in Fig. 9.31. The fuel rods are $0.490 \mathrm{in}$. in nominal diameter and are $0.685 \mathrm{in.}$ long, except for the thermocouple rods which are 0.735 in. 1ong. The fuel particle combinations, the particle batches used in the rods, and the positions of the various rods in the capsule are shown in Table 9.2. The properties of the fuel particles to be irradiated both in the rods and as thimble samples in cell 4 are reviewed in Table 9.3. The latter samples will operate at $1350^{\circ} \mathrm{C}$ to about $6 \times 10^{21} \mathrm{n} / \mathrm{cm}^{2}$.

Both the particles and the rods were fabricated in production equipment using standard processes and procedures. All the fuel rods were hot-injection molded using a matxix containing $27 \mathrm{wt}-\%$ natural-flake filler and $73 \% 15 \mathrm{~V}$ pitch binder. All of the rods in cell 3 and one set of rods in cell 5 contain some inert coated particles in order to satisfy the uranium and thorium loading requirements. The properties of these particles are also listed in Table 9.2.

Because of the importance of obtaining thermocouple decalibration data to apply to the operation of subsequent capsules and to the analysis of the completed experiments, P13M contains two thermocouple decalibration cells in addition to the particle and rod cells. One cell will operate at $950^{\circ} \mathrm{C}$ to about $8 \times 10^{21} \mathrm{n} / \mathrm{cm}^{2}$; the other will be at $1250^{\circ} \mathrm{C}$ to about $6 \times 10^{21} \mathrm{n} / \mathrm{cm}^{2}$. (The only decalibration data now available are at $950^{\circ} \mathrm{C}$ to $2.8 \times 10^{21} \mathrm{n} / \mathrm{cm}^{2}$ from capsule BG-2.) 


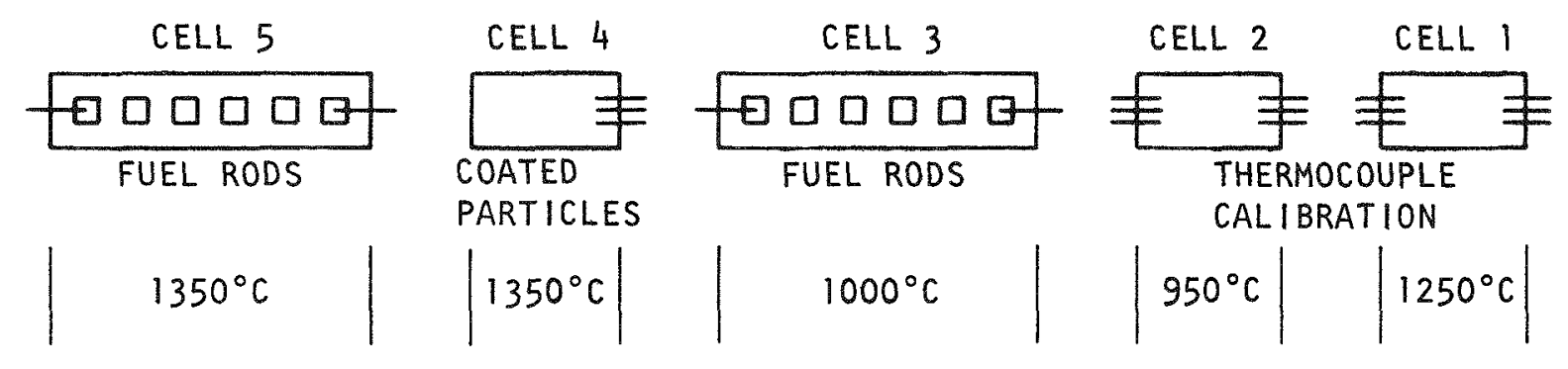

$\stackrel{9}{\circ}$

$$
\begin{array}{ccccc}
4 \text { TO } 5 & 6 \text { TO } 7 & 8 & 7.5 \text { TO } 8 & 6 \\
\left(10^{21} \mathrm{~N} / \mathrm{CM}^{2}\right) & \left(10^{21} \mathrm{~N} / \mathrm{CM}^{2}\right) & \left(10^{21} \mathrm{~N} / \mathrm{CM}^{2}\right) & \left(10^{21} \mathrm{~N} / \mathrm{CM}^{2}\right) & \left(10^{21} \mathrm{~N} / \mathrm{CM}^{2}\right)
\end{array}
$$

Fig. 9.31. Capsule P13M layout showing five cells 
TABLE 9.2

DETAILS OF FUEL RODS IRRADIATED IN CAPSULE P13M

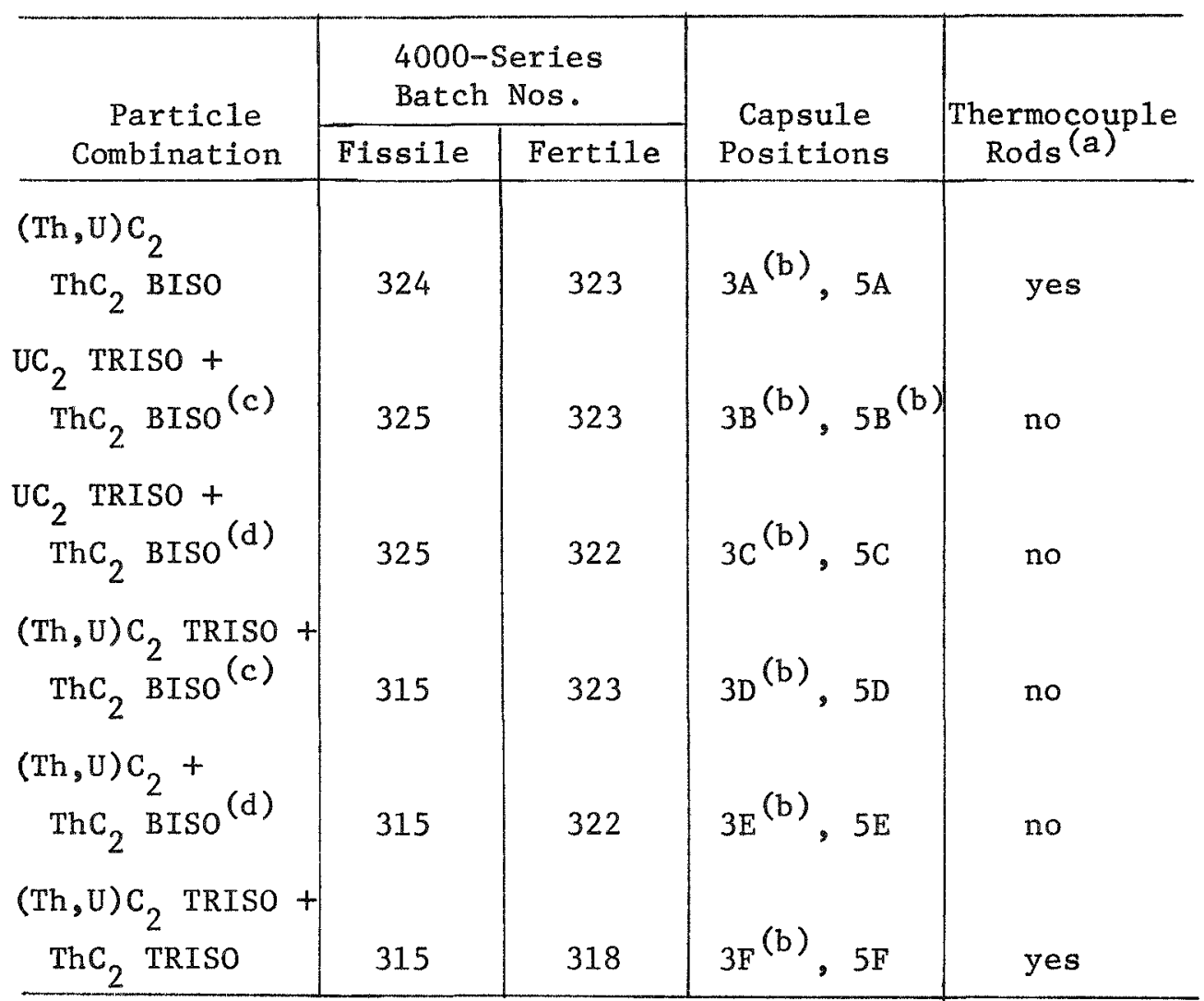

(a) Rods containing thermocouples are nominally 0.490 in. diameter by 0.735 in. long; rods without thermocouples are 0.490 in. diameter by 0.685 in. 1ong.

(b) Inert particles from batch $3516-79$ also used.

(c) High-density PyC outer coating.

(d) Low-density PyC outer coating. 
TABLE 9.3

PROPERTIES OF COATED PARTICLES IRRADIATED IN CAPSULE P13M

\begin{tabular}{|c|c|c|c|c|c|c|c|c|c|c|c|c|c|}
\hline \multirow[b]{2}{*}{$\begin{array}{l}\text { Particle } \\
\text { Batch No. }\end{array}$} & \multirow{2}{*}{$\begin{array}{c}\text { Coated } \\
\text { Particle } \\
\text { Type }\end{array}$} & \multicolumn{2}{|c|}{ Kernel } & \multicolumn{2}{|c|}{ Buffer } & \multicolumn{3}{|c|}{ Inner Isotropic } & \multicolumn{2}{|c|}{ Sic } & \multicolumn{3}{|c|}{ Outer Isotropic } \\
\hline & & Type & $\begin{array}{l}\text { Diam } \\
\text { ( } \mu \mathrm{m})\end{array}$ & $\begin{array}{c}\text { Thickness } \\
(\mu \mathrm{m})\end{array}$ & $\begin{array}{l}\text { Density } \\
\left(\mathrm{g} / \mathrm{cm}^{3}\right)\end{array}$ & $\begin{array}{c}\text { Thickness } \\
(\mu \mathrm{m})\end{array}$ & $\begin{array}{l}\text { Density } \\
\left(\mathrm{g} / \mathrm{cm}^{3}\right)\end{array}$ & $\operatorname{OPTAF}^{(a)}$ & $\begin{array}{c}\text { Thickness } \\
(\mu \mathrm{m})\end{array}$ & $\begin{array}{l}\text { Density } \\
\left(\mathrm{g} / \mathrm{cm}^{3}\right)\end{array}$ & $\begin{array}{l}\text { Thickness } \\
\text { (N⿴囗十) }\end{array}$ & $\begin{array}{l}\text { Density } \\
\left(\mathrm{g} / \mathrm{cm}^{3}\right)\end{array}$ & OPTAF (a) \\
\hline In Fuel Rods: & & & & & & & & & & & & & \\
\hline $4000-315$ & TRISO & $(\mathrm{Th}, \mathrm{U}) \mathrm{C}_{2}$ & 175 & 47 & 1.27 & 17 & 1.87 & $1.24^{(b)}$ & 22 & 3.19 & 42 & 1.78 & $1.28^{(b)}$ \\
\hline $4000-318$ & TRISO & $\mathrm{ThC}_{2}$ & 384 & 49 & 1.14 & 21 & 1.88 & 1.10 & 25 & 3.20 & 39 & 1.78 & 1.10 \\
\hline $4000-322$ & BIso & $\mathrm{ThC}_{2}$ & 360 & 60 & 1.27 & - & -- & -- & - & -- & 80 & 1.70 & 1.08 \\
\hline $4000-323$ & BISO & $\mathrm{ThC}_{2}$ & 351 & 66 & 1.24 & - & - & - & -- & - & 67 & 1.84 & 1.10 \\
\hline $4000-324$ & BISO & $(\mathrm{Th}, \mathrm{U}) \mathrm{C}_{2}$ & 182 & 60 & 1.27 & - & - & -- & -- & - & 60 & 1.88 & 1.17 \\
\hline $4000-325$ & TRISO & $\mathrm{uc}_{2}$ & 93 & 50 & 1.29 & 22 & 1.81 & 1.22 & 20 & 3.19 & 27 & 1.71 & 1.11 \\
\hline $3516-79$ & INERT & $\mathrm{SiC}$ & 377 & - & -- & - & - & - & - & -- & 41 & 1.77 & 1.10 \\
\hline Loose Particle & & & & & & & & & & & & & \\
\hline $4000-232$ & TRISO & $(\mathrm{Th}, \mathrm{U}) \mathrm{C}_{2}$ & 198 & 51 & 1.06 & 19 & 1.86 & (c) & 21 & 3.21 & 38 & 1.78 & (c) \\
\hline $4000-273^{(d)}$ & BISO & $\mathrm{ThO}_{2}$ & (c) & 51 & (c) & -- & - & - & -- & -- & 81 & (c) & (c) \\
\hline $4000-304$ & TRISO & $\mathrm{UC}_{2}$ & 97 & 51 & 1.28 & 24 & 1.80 & (c) & 19 & 3.21 & 30 & 1.79 & (c) \\
\hline $4000-316$ & TRISO & $(\mathrm{Th}, \mathrm{U}) \mathrm{C}_{2}$ & 138 & 59 & 1.17 & 24 & 1.84 & $1.22^{(b)}$ & 23 & 3.19 & 30 & 1.84 & $1.30^{(b)}$ \\
\hline $4413-67$ & TRISO & $\mathrm{vo}_{2}$ & 125 & 46 & 1.26 & 22 & 1.85 & (c) & 20 & 3.16 & 22 & 1.75 & (c) \\
\hline $3516-71$ & INERT & $\mathrm{SiC}$ & 377 & - & -- & - & - & -- & -- & -- & 47 & 1.81 & 1.11 \\
\hline
\end{tabular}

(a) OPTAF = Optical Anisotropy Factor.

(b) Spec was $\leq 1.40$ at time of determination.

(d) Fabricated by ORNL. 
TASK XI

GRAPHITE RESEARCH

\section{CARBON COATING IRRADIATION}

A study of the dimensional changes induced in poorly crystalline isotopic carbon as a result of the irradiation has been completed on the carbons in capsules F28, F29, P22, and P13L. A more detailed presentation of this study will be found in Ref. 1, which is now being prepared for publication. The principal conclusions to be drawn from this study are given below together with a series of figures on which the conclusions were based:

1. In contrast to the HTI carbons, the LTI carbons do not increase in volume at high fast-neutron fluences (see Figs. 11.1 and 11.2). Instead, they approach a constant density that is independent of the irradiation temperature and depends only on the initial density, as may be seen in Fig. 11.3.

2. The linear dimensional changes of LTI carbons at temperatures below $1000^{\circ} \mathrm{C}$ are not greatly different from those of HTI carbons (see Figs. 11.4 and 11.5). At temperatures above $1000^{\circ} \mathrm{C}$, however, the linear changes of LTI carbons do not increase strongly with temperature, whereas those of the HTI carbons do.

3. Carbons deposited from different gases but with the same structural parameters of density, crystallite size, and Bacon anisotopy factor behave in the same fashion under irradiation (see Fig. 11.6).

4. Annealing of the LTI carbons before irradiation reduces the subsequent irradiation-induced component of densification (see Fig. 11.7). 
5. LTI carbons with smaller crystallite sizes densify to a greater extent and apparently change dimensions to a lesser extent than LTI carbons having larger crystallite sizes (Figs. 11.8 and 11.9).

CONTROL MATERIALS IRRADIATIONS

\section{Capsule BG-2}

The primary purpose of the $B G-2$ experiment (GA-19-2) is to measure the effects of neutron irradiation on boronated ( $B$ or $B_{4} C$ plus graphite) and hafnated (HfC plus graphite) compacts. Appearance changes in boron fibers and density changes in loose granules of $\mathrm{B}_{4} \mathrm{C}$ and $\mathrm{HfC}$ will also be determined in piggyback specimens to enhance the knowledge of irradiation effects in these poison materials in the absence of a bonding matrix material. A better understanding of irradiation effects in boronated and hafnated graphite should result from this investigation.

Irradiation-induced dimensional change is the phenomenon of primary interest; however, a correlation of thermal expansion coefficient, strength, and microstructure with neutron exposure has also been conducted. Some specimens irradiated previously in capsule BG-1, described in earlier quarterly report GA-9372 and in Ref. 2, continued irradiation exposure in capsule BG-2. A detailed summary of the samples being tested in $B G-2$ was given in earlier quarterly report GA-9660. The design of BG-2 was basically the same as BG-1 as described in Ref. 2.

The capsule was inserted in the ETR and started irradiation in July 1969 (cycle 103) at temperatures of $600^{\circ}$ to $700^{\circ} \mathrm{C}$. The capsule remained in the ETR through cycle 106 and was removed in May 1970. The capsule was opened at the Gulf General Atomic hot cell facility, and initial observations were reported in an earlier quarterly report (GA-10299). Dimensional change effects were reported in the previous quarterly report (GA-10399). During this report period the postirradiation examination of specimens has continued and is near completion. 


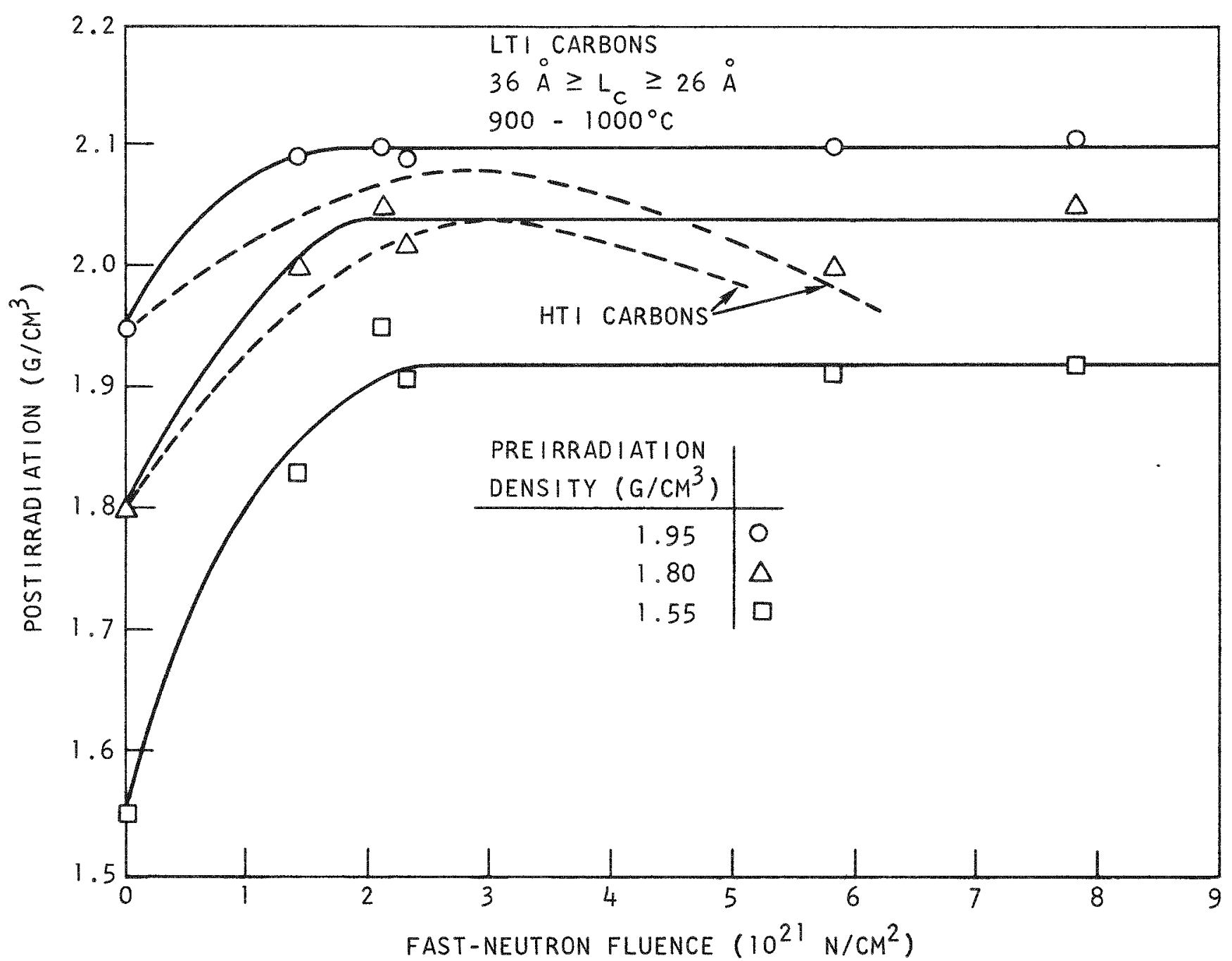

Fig. 11.1. Postirradiation density as a function of fast-neutron fluence at $900^{\circ}$ to $1000^{\circ} \mathrm{C}$ for LTI carbons $\left(36 \AA \geq L_{c} \geq 26 \AA\right)$ and HTI carbon 


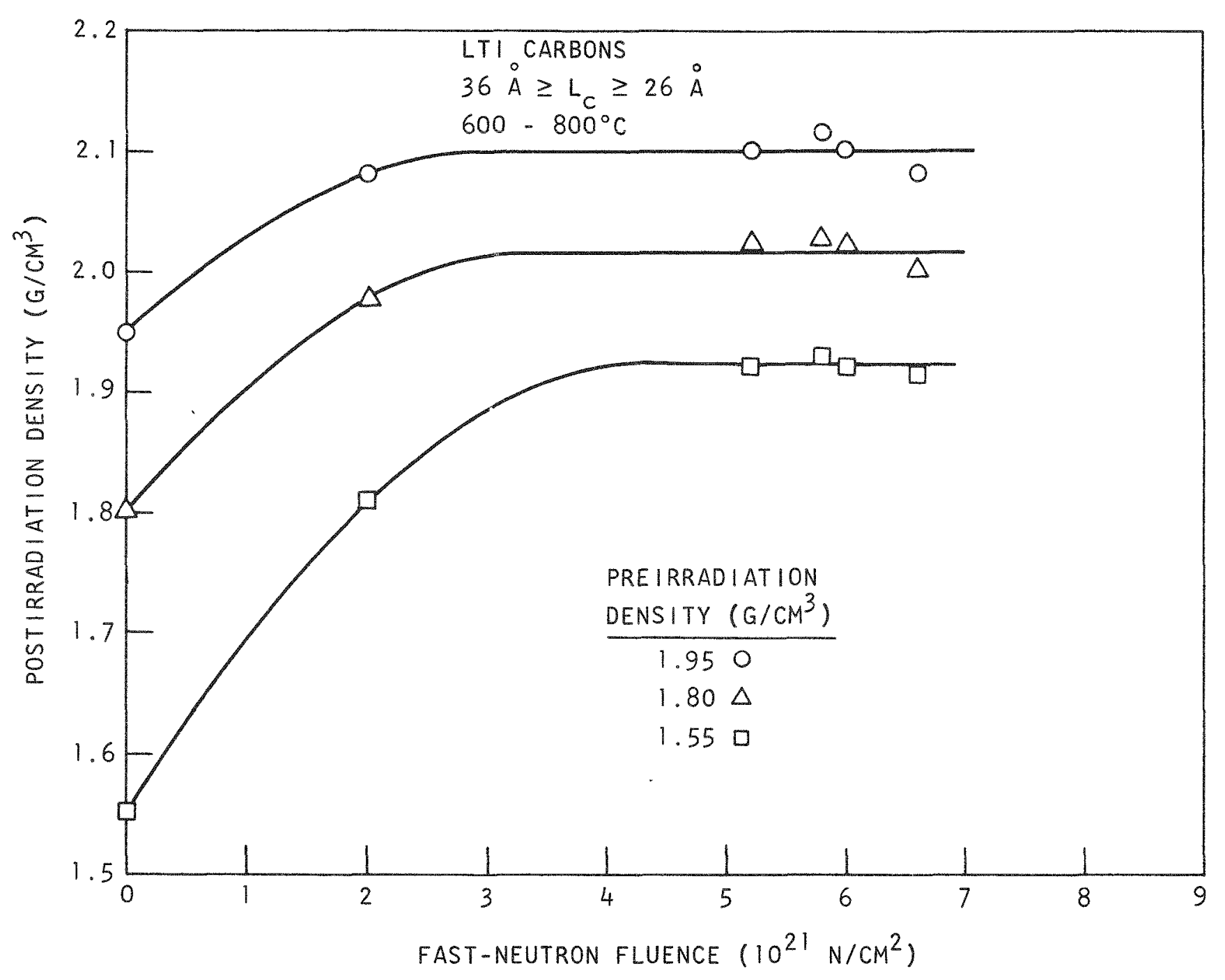

Fig. 11.2. Postirradiation density as a function of fast-neutron fluence at $600^{\circ}$ to $800^{\circ} \mathrm{C}$ for LTI carbons $\left(36 \AA \geq L_{c} \geq 26 \AA\right)$ 


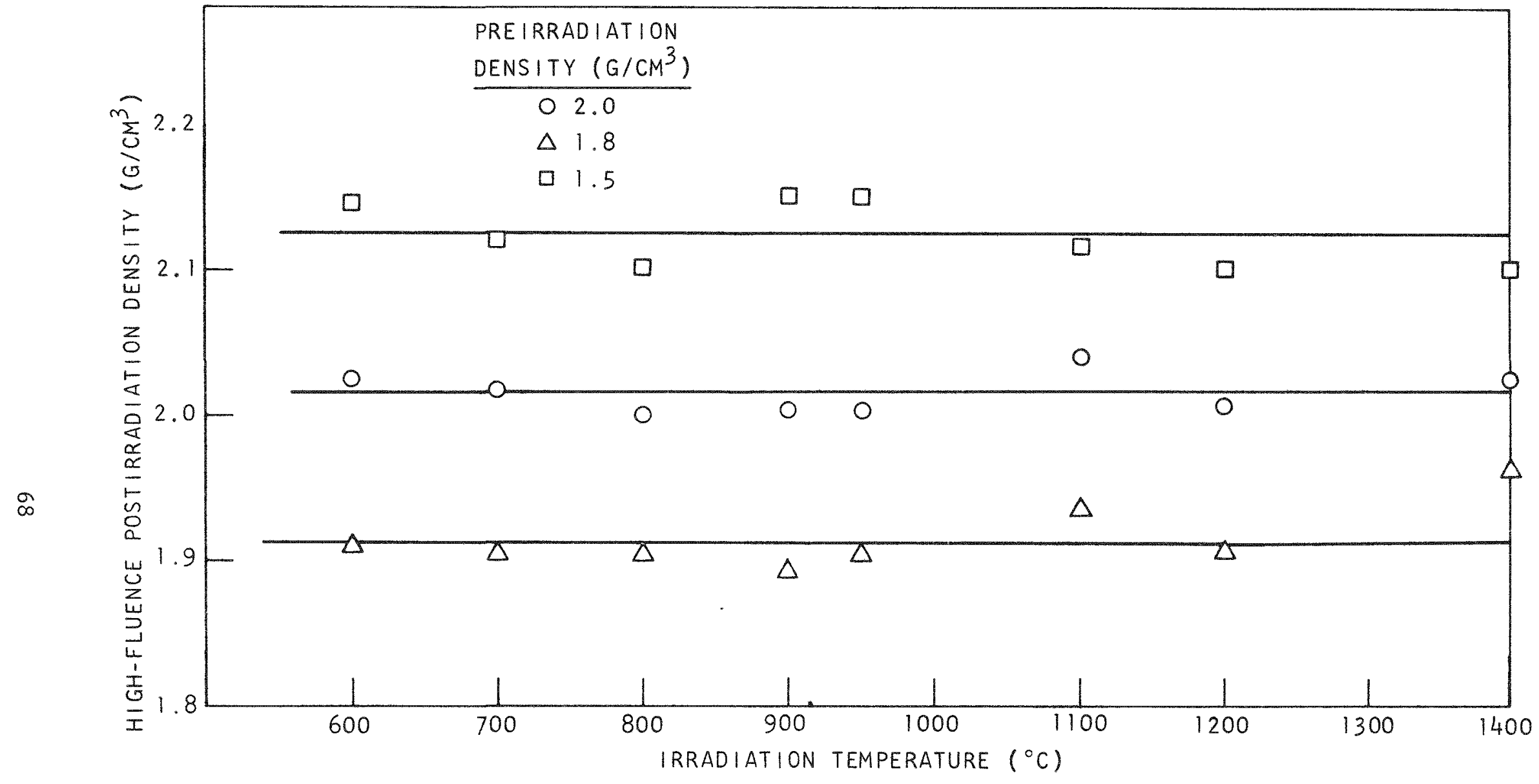

Fig. 11.3. Effect of irradiation temperature on the high-fluence postirradiation density of LTI carbons $\left(36 \AA \geq L_{c} \geq 26 \AA\right)$ 


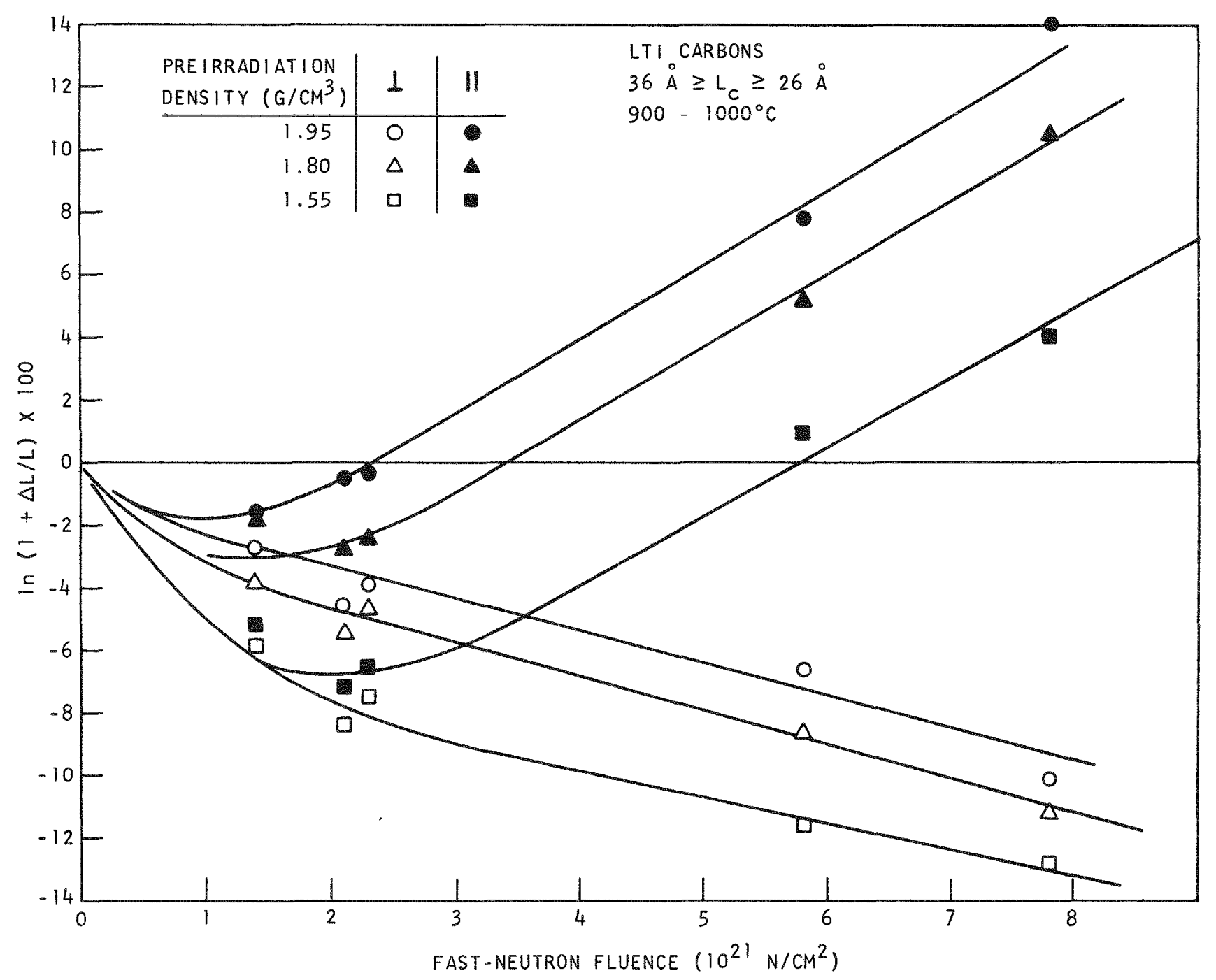

Fig. 11.4. Dimensional change as a function of fast-neutron fluence at $900^{\circ}$ to $1000^{\circ} \mathrm{C}$ for LTI carbons $\left(36 \AA \geq L_{c} \geq 26 \AA\right)$ 


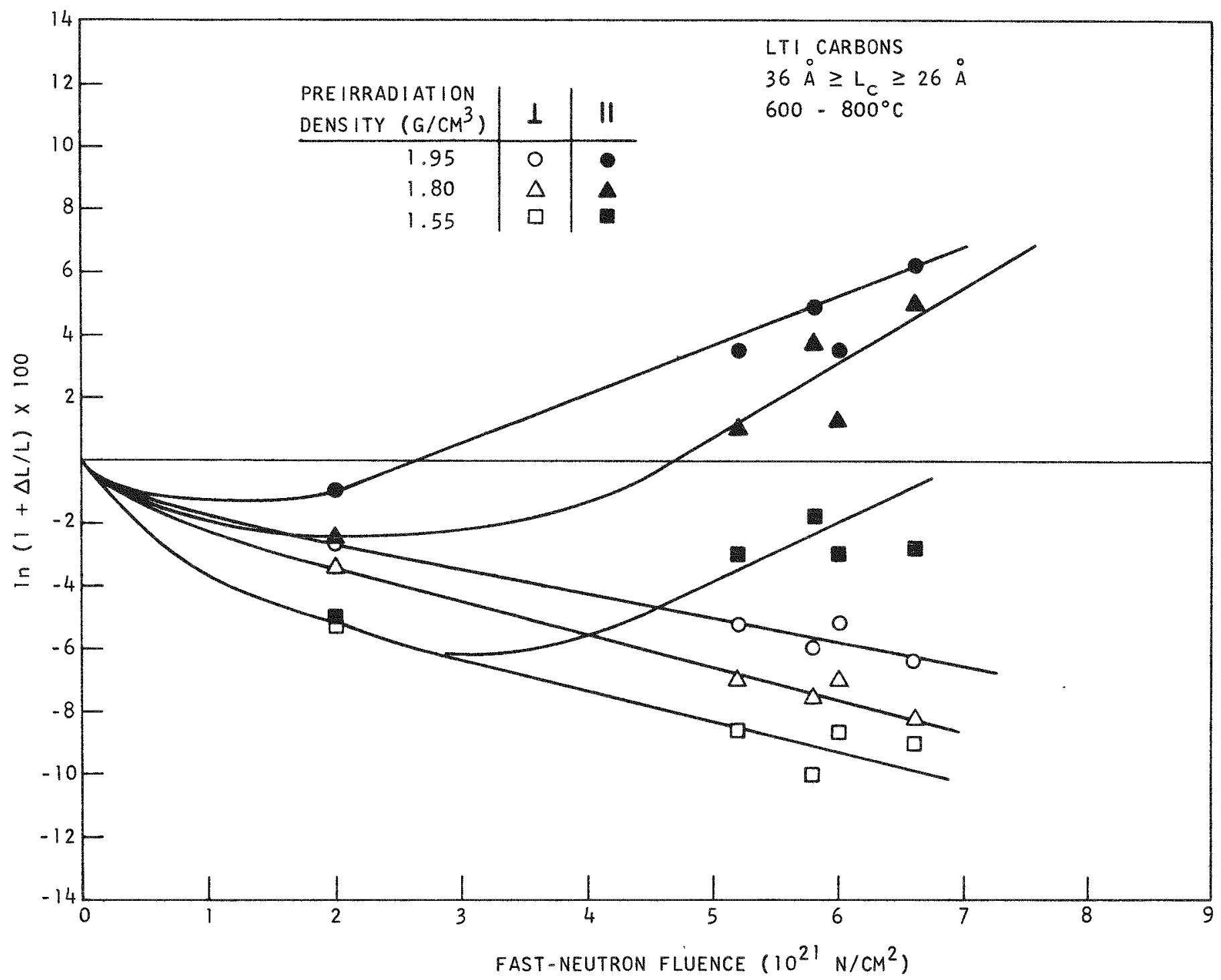

Fig. 11.5. Dimensional change as a function of fast-neutron fluence at $600^{\circ}$ to $800^{\circ} \mathrm{C}$ for LTI carbons $\left(36 \AA z L_{c} \geq 26 \AA\right)$ 


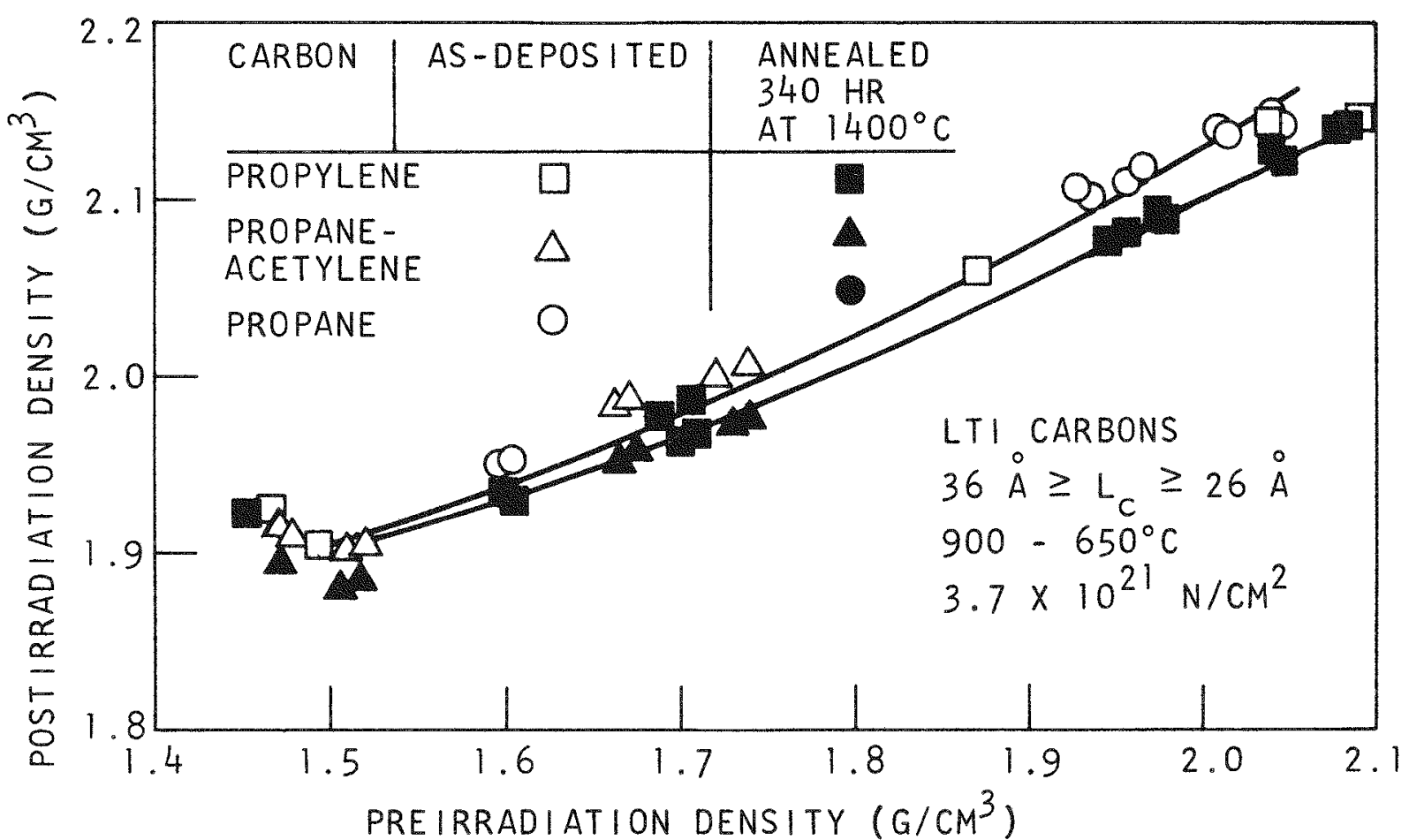

Fig. 11.6. Postirradiation density as a function of preirradiation density of LTI carbon derived from different source gases and irradiated to $3.7 \times 10^{21} \mathrm{n} / \mathrm{cm}^{2}$ at $900^{\circ}$ to $650^{\circ} \mathrm{C}$ 


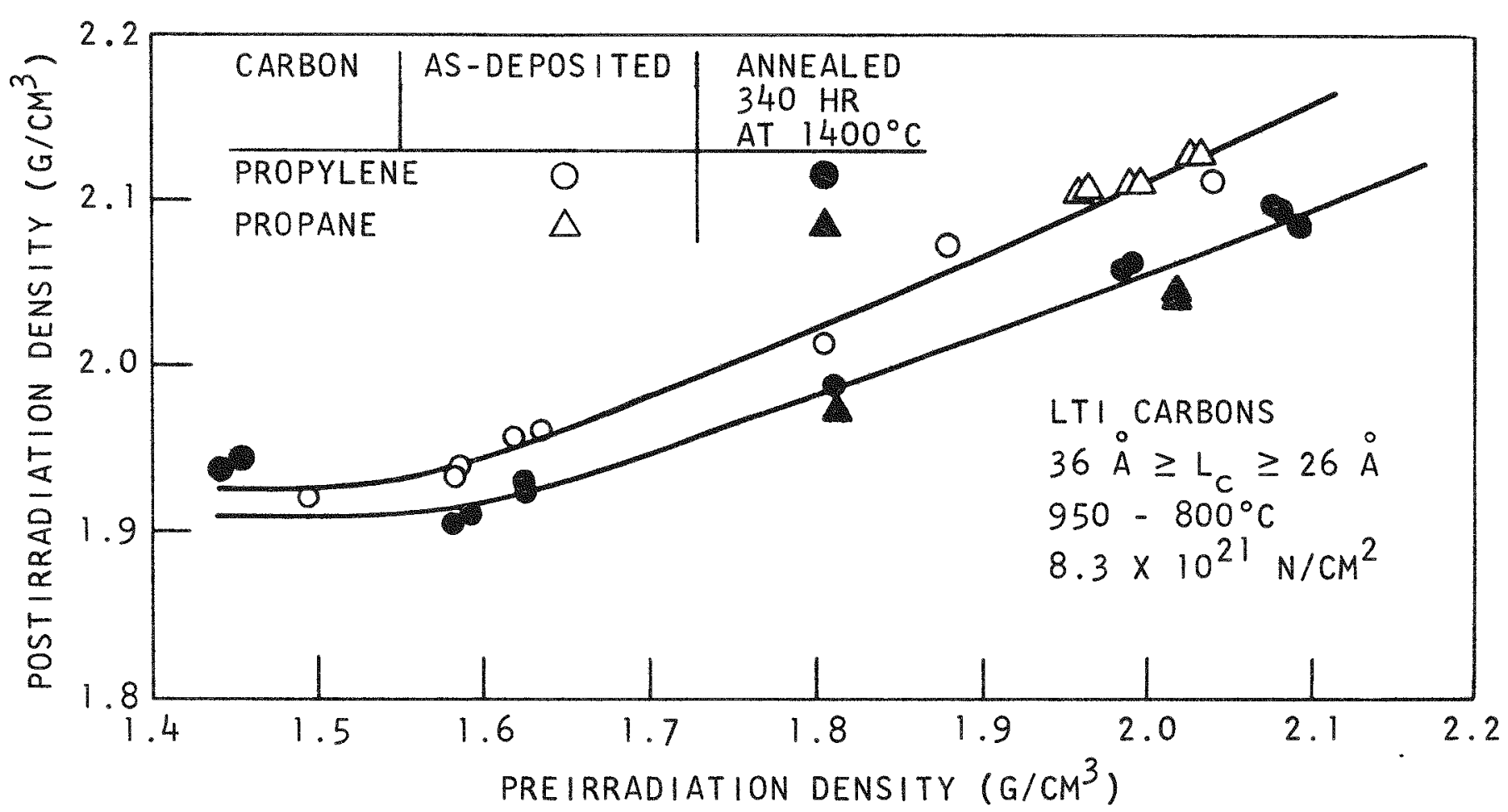

Fig. 11.7. Postirradiation density as function of preirradiation density for as-deposited carbons annealed for $34 \mathrm{hr}$ at $1400^{\circ} \mathrm{C}$ and irradiated to $8.3 \times 10^{21} \mathrm{n} / \mathrm{cm}^{2}$ at $950^{\circ}$ to $800^{\circ} \mathrm{C}$ 


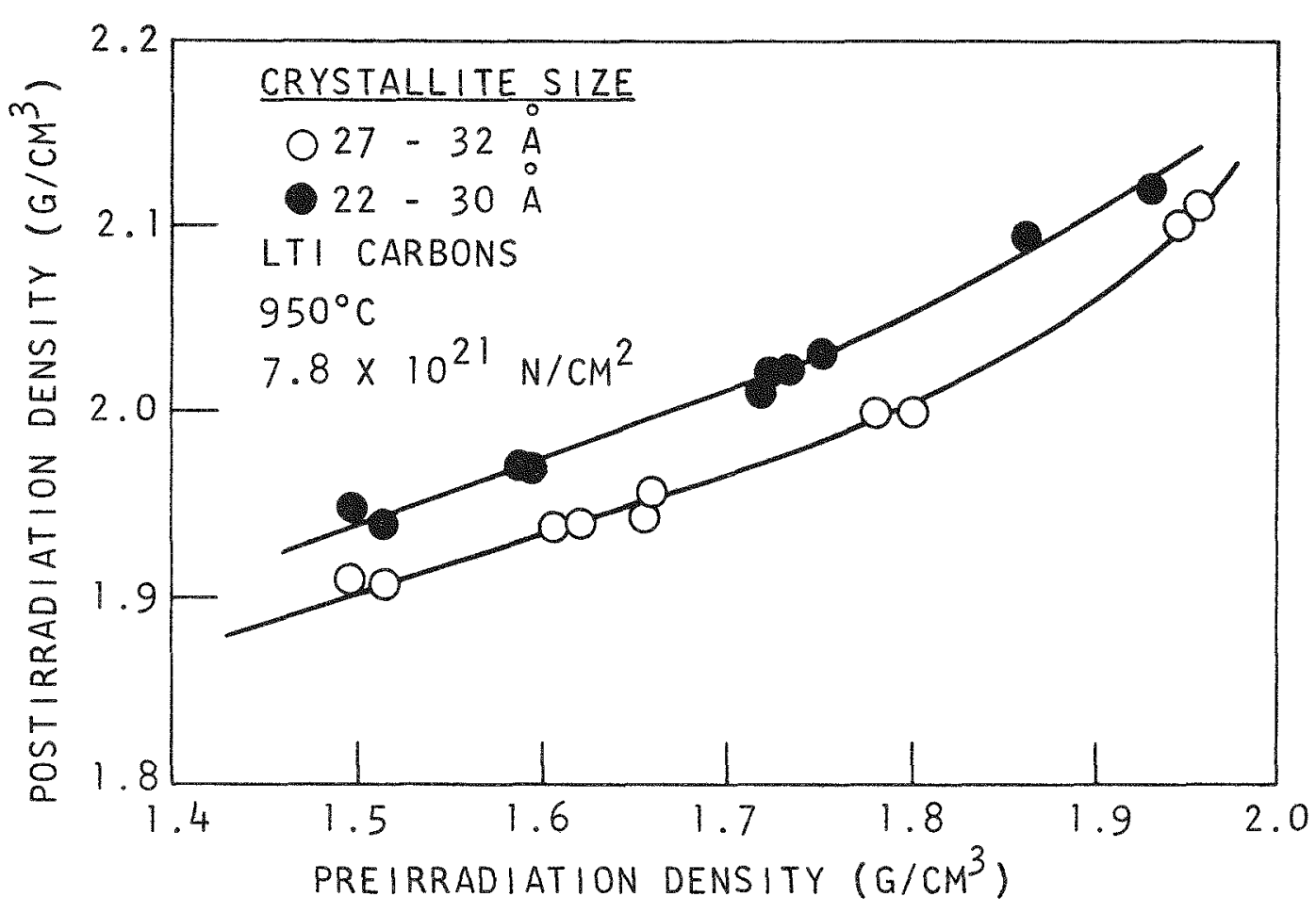

Fig. 11.8. Postirradiation density as a function of preirradiation density for LTI carbons irradiated to $7.8 \times 10^{21} \mathrm{n} / \mathrm{cm}^{2}$ at $950^{\circ} \mathrm{C}$ 


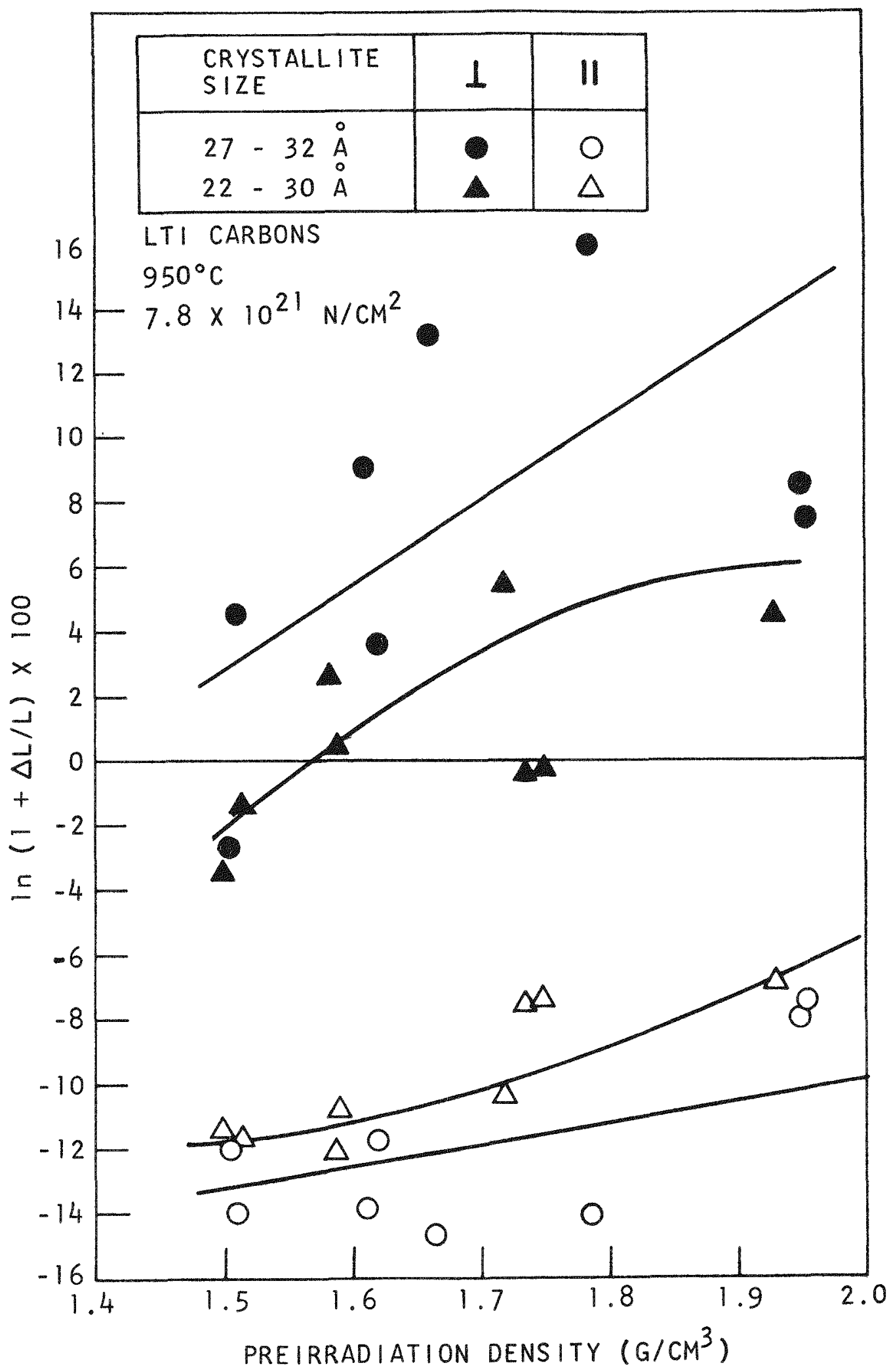

Fig. 11.9. Dimensional change as a function of postirradiation density for LTI carbons irradiated to $7.8 \times 10^{21} \mathrm{n} / \mathrm{cm}^{2}$ at $950^{\circ} \mathrm{C}$ 
BORONATED GRAPHITE

Dosimetry

The profile of fast- and thermal-neutron fluence experienced along the length of capsule BG-2 is shown in Fig. 11.10. The fast-neutron exposure ( $E>0.18 \mathrm{Mev}$ ) was determined from analysis of Fe wires activated by the $\mathrm{Fe}-54(\mathrm{~N}, \mathrm{P}) \mathrm{Mn}-54$ reaction with a $51.2-\mathrm{mb}$ cross section. The fast-neutron exposure was the same in both the shielded and unshielded region of the specimens. The thermal-neutron exposure ( $\mathrm{E}<0.4 \mathrm{ev}$ ) was determined from analysis of $\mathrm{Ni}-0.45 \%$ Co wires activated by the Co-59 $(\mathrm{N}, \gamma)$ Co-60 reaction with a 36.8-b cross section. The thermal-neutron exposure, as defined here, was two to three times lower in the shielded portion than in the unshielded portion of the specimens. The neutron exposure received by each specimen is shown in Table 11.1, which is repeated from the previous quarterly report (GA-10399) in more complete form.

\section{B-10 Isotope Burnup}

Samples were taken for B-10 - B-11 isotope analysis by scraping the surface of selected samples with a clean steel file, with precautions taken to avoid cross contamination. A section 0.2 in. square, 0.02 in. deep, and weighing about $0.020 \mathrm{~g}$ was removed from the specimen surfaces exposed in the thermal-neutron window and from the shielded side. Some cylindrical specimens also had samples removed by drilling at the center on the bottom. Isotopic analysis was performed by mass spectrographic techniques at AVCO Analytical Laboratories, and the results of this work are shown in Table 11.1. The profile of B-10 burnup along the length of the capsule is shown in Fig. 11.11 . The B-10 burnup within the specimens in the neutron window was about two times that in the middle and on the shielded side. Results from isotopic analysis of two specimens (material 3912-34 and 3685-124-1000) shown in Table 11.1 were not shown in Fig. 11.11 because of unexplained anomalous results. In both cases the extent of $\mathrm{B}-10$ burnup was less than anticipated and did not decrease from the window to the shielded side. 


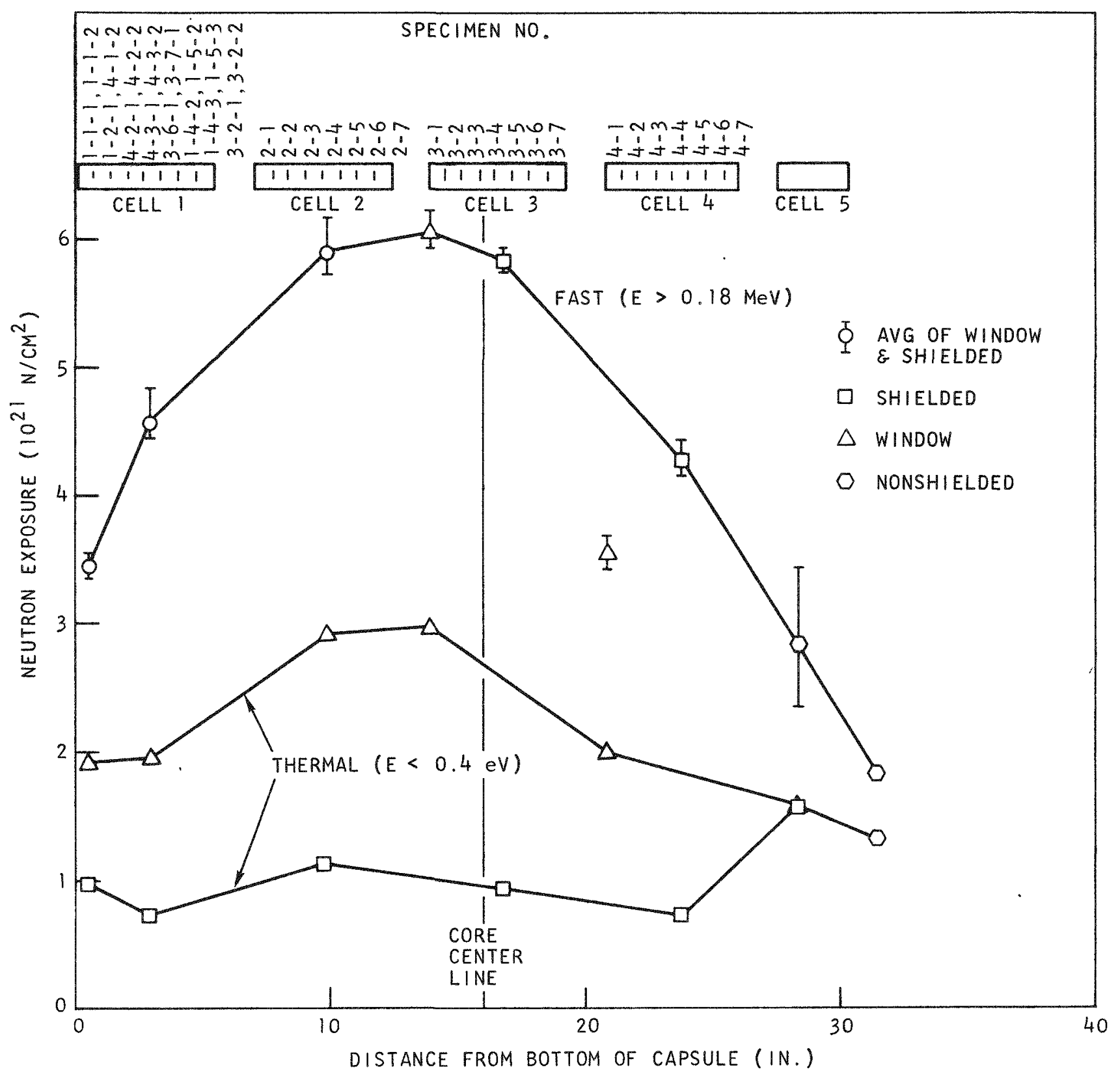

Fig. 11.10. Thermal and fast--neutron exposure profile of capsule BG-2 


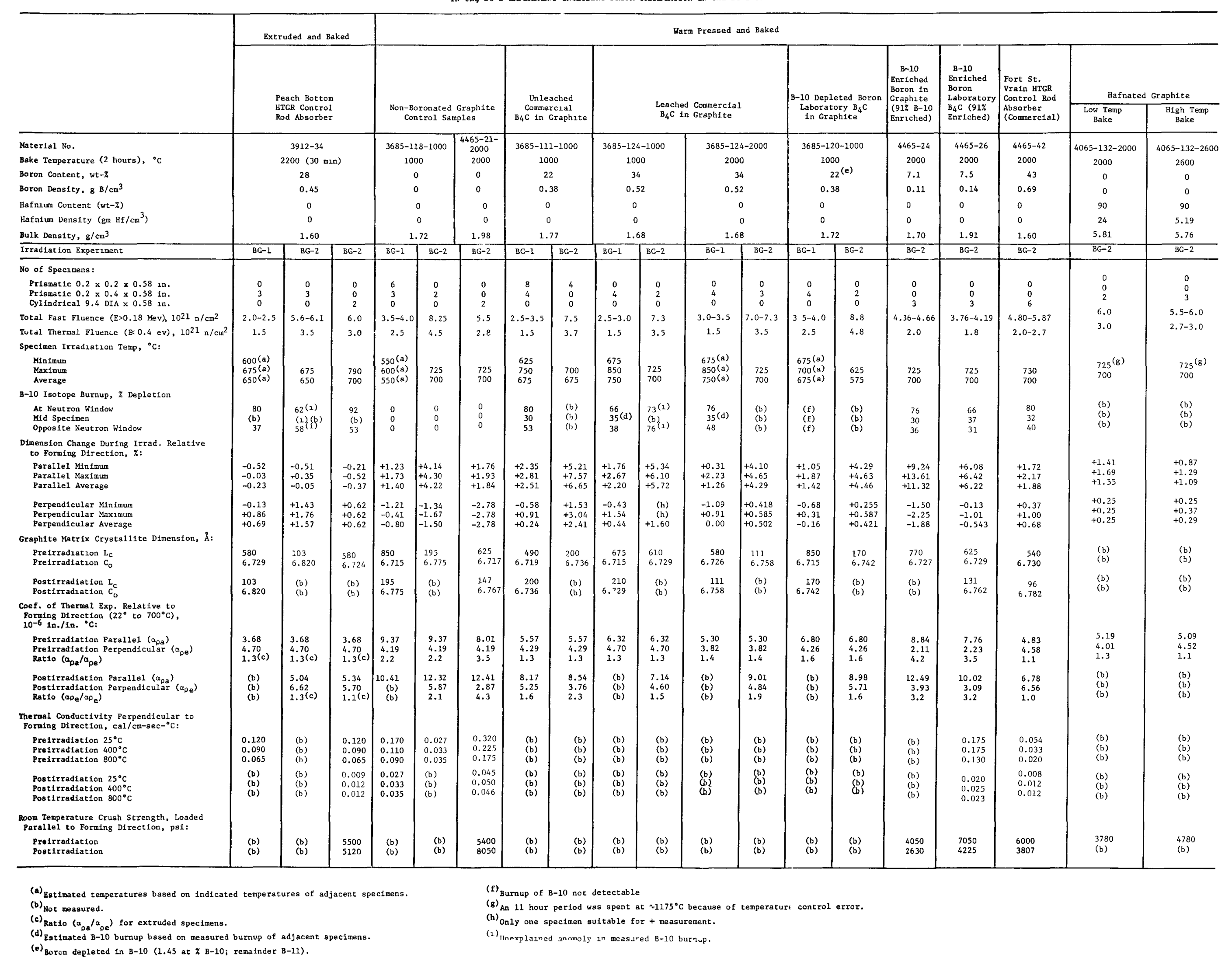


-

0 


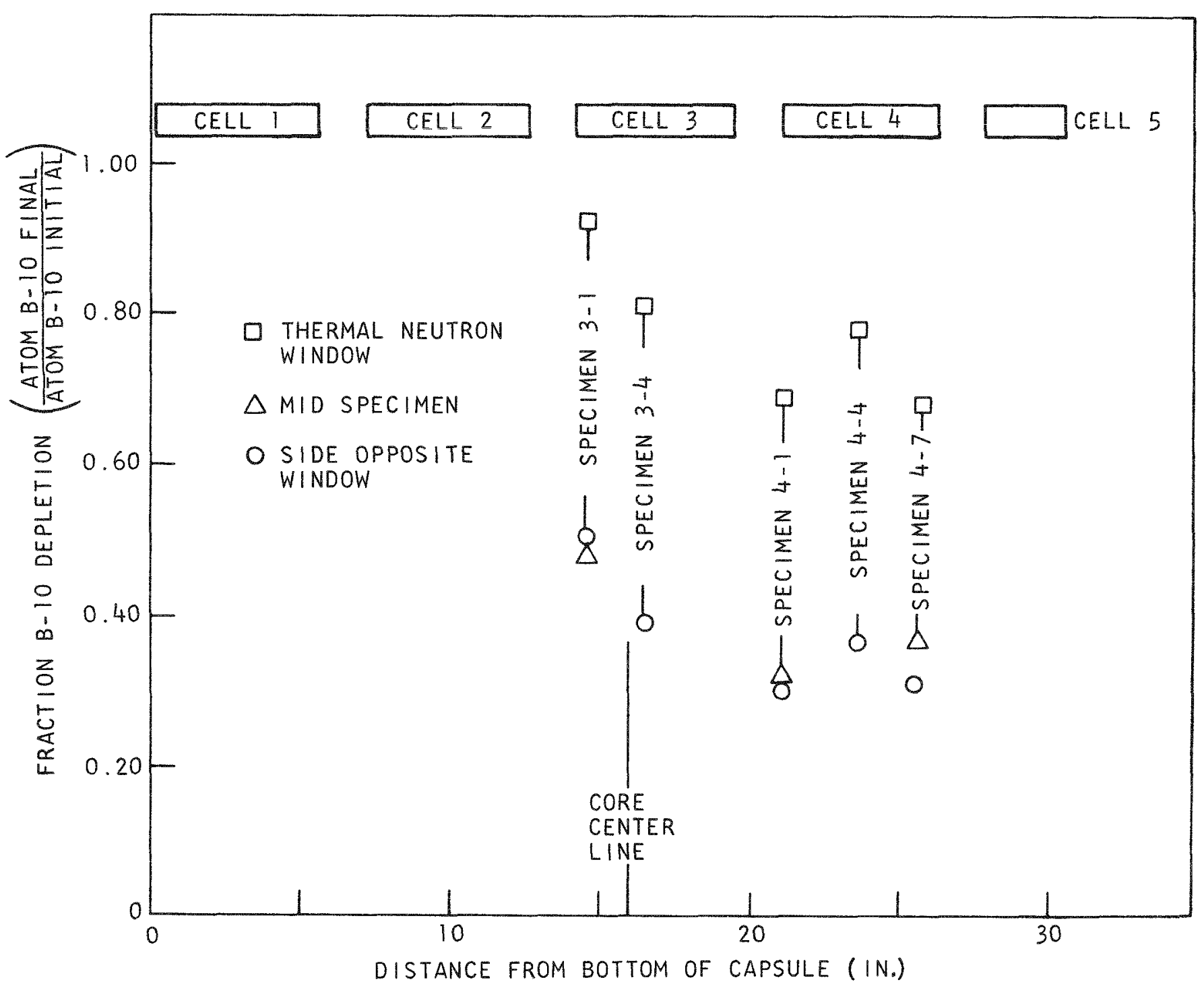

Fig. 11.11. B-10 burnup profile for BG-2 specimens 


\section{Thermal Conductivity}

The thermal conductivity of four materials was determined between room temperature and $800^{\circ} \mathrm{C}$ before and after irradiation in capsule $B G-2$. The xenon flash method (Ref. 3) was employed with specimens 0.30 in. in diameter by $0.060 \mathrm{in}$. thick, shaped so that the direction of measurements was perpendicular to the forming direction. Neuman and Kopp's additivity rule for the specific heat of $B_{4} C$ and graphite (as shown in Table 11.2) was used in calculating the heat capacity (Ref. 4). The results of thermal conductivity measurements are shown in Table 11.1 .

The thermal conductivity before irradiation generally decreased rapidly with increasing temperature. After irradiation the thermal conductivity was not very temperature sensitive and was a factor of two to five less than the unirradiated values.

TABLE 11.2

HEAT CAPACITY OF GRAPHITE, BORON CARBIDE, AND BORONATED GRAPHITES

\begin{tabular}{|c|c|c|c|c|c|}
\hline \multirow{3}{*}{$\begin{array}{l}\text { Temp } \\
\left({ }^{\circ} \mathrm{C}\right)\end{array}$} & \multirow[b]{3}{*}{ Graphite } & \multicolumn{4}{|c|}{ Heat Capacity $\left(\mathrm{Ca} 1 / \mathrm{g}-^{\circ} \mathrm{C}\right)$} \\
\hline & & & \multicolumn{3}{|c|}{$\begin{array}{c}\text { Boronated Graphite } \\
\left(\begin{array}{lll}W t-\% & \left.B_{4} \mathrm{C}\right)\end{array}\right.\end{array}$} \\
\hline & & $\mathrm{B}_{4} \mathrm{C}$ & 10 & 28 & 43 \\
\hline 25 & 0.174 & 0.225 & 0.180 & 0.188 & 0.196 \\
\hline 100 & 0.223 & 0.255 & 0.226 & 0.232 & 0.237 \\
\hline 200 & 0.279 & 0.285 & 0.280 & 0.281 & 0.282 \\
\hline 300 & 0.325 & 0.330 & 0.326 & 0.326 & 0.327 \\
\hline 400 & 0.360 & 0.345 & 0.359 & 0.356 & 0.354 \\
\hline 500 & 0.388 & 0.375 & 0.387 & 0.384 & 0.382 \\
\hline 600 & 0.410 & 0.400 & 0.409 & 0.410 & 0.406 \\
\hline 700 & 0.426 & 0.425 & 0.426 & 0.426 & 0.426 \\
\hline 800 & 0.439 & 0.450 & 0.440 & 0.442 & 0.444 \\
\hline
\end{tabular}




\section{Graphite Crystallite Dimensions}

Crystallite dimensions ( $L_{c}$ and $c_{0}$ ) of the graphitic phase of all boronated materials were measured by X-ray diffractometer before irradiation and in three materials after irradiation. The powdered samples were held between tape during the $X$-radiation exposure. The results of that work are shown in Table 11.1.

The graphite filler crystallite size $\left(\mathrm{L}_{c}\right)$ decreased with irradiation, and the average layer spacing $\left(c_{0}\right)$ increased. These observations are consistent with expected damage due to fast-neutron and B-10 fission damage in the graphite. The accuracy of the measurements was not sufficient to detect the presence of boron in solution in the graphite.

\section{Appearance of Specimens}

Photographs of specimens that exhibited a measurable bowing were shown in the previous quarterly report (GA-10399). Specimens of boronated graphite more typical of those in capsule BG-2 are shown in Figs. 11.12 and 11.13. The only change in appearance of the specimens was a darkening in some areas by a soot-like deposit.

\section{Microstructure}

The microstructure of a typical boronated graphite before and after irradiation was shown in the previous quarterly report (GA-10399). There was no correlation between the B-10 burnup gradient and the microstructure. Additional work was conducted during this report period, but no exception to the initial observation was found.

In general, the $\mathrm{B}_{4} \mathrm{C}$ granules within the graphite matrix underwent fracturing along apparent grain boundaries during irradiation. The specimens continuing irradiation from capsule BG-1 showed no change in microstructure from that shown in Ref. 2 . 


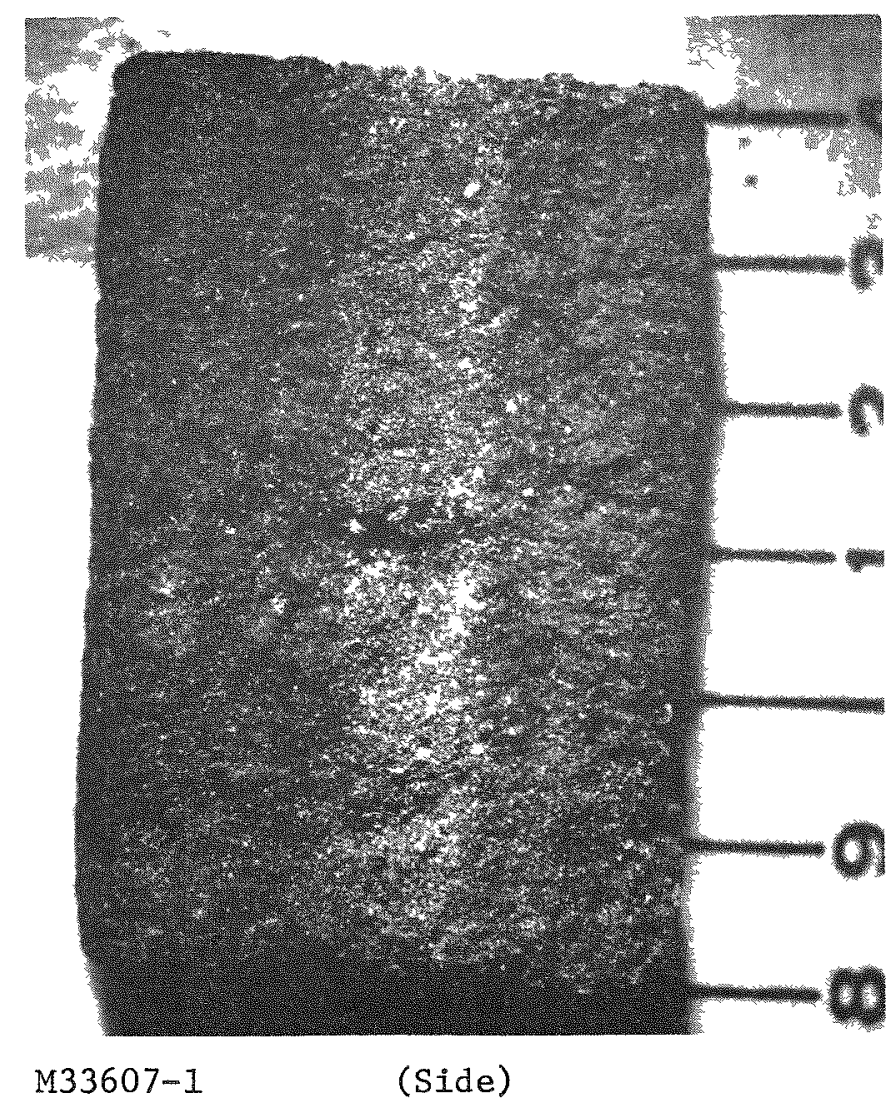

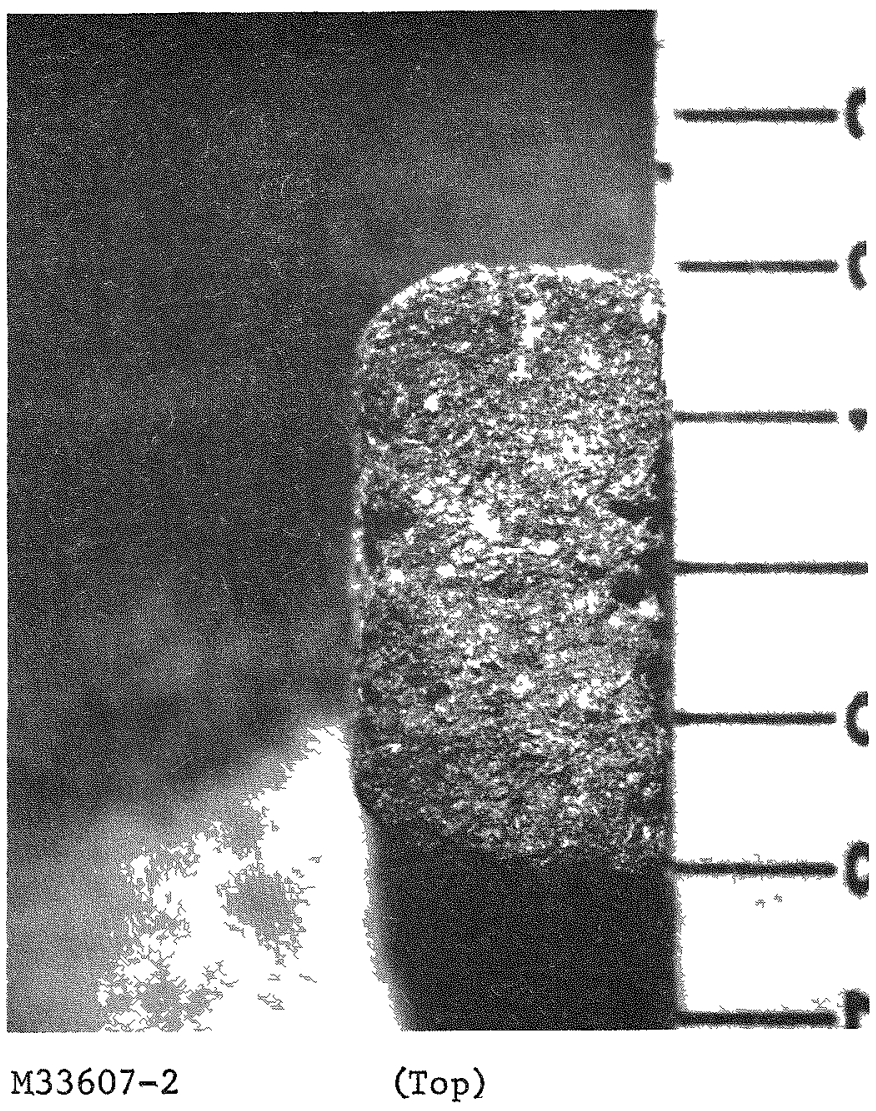

Fig. 11.12. Warm-pressed boronated graphite (material 3685-124-2000, specimen 4-2-2) made with leached technical grade $\mathrm{B}_{4} \mathrm{C}\left(0.52 \mathrm{~g}\right.$ natural $\left.\mathrm{B} / \mathrm{cm}^{3}\right)$ baked at $2000^{\circ} \mathrm{C}$ and irradiated at $700 \pm 50^{\circ} \mathrm{C}$ to a fast-neutron exposure of $7.2 \times 10^{21} \mathrm{n} / \mathrm{cm}^{2}(\mathrm{E}>0.18 \mathrm{Mev}$ ) in capsules $\mathrm{BG}-1$ and $\mathrm{BG}-2$ 


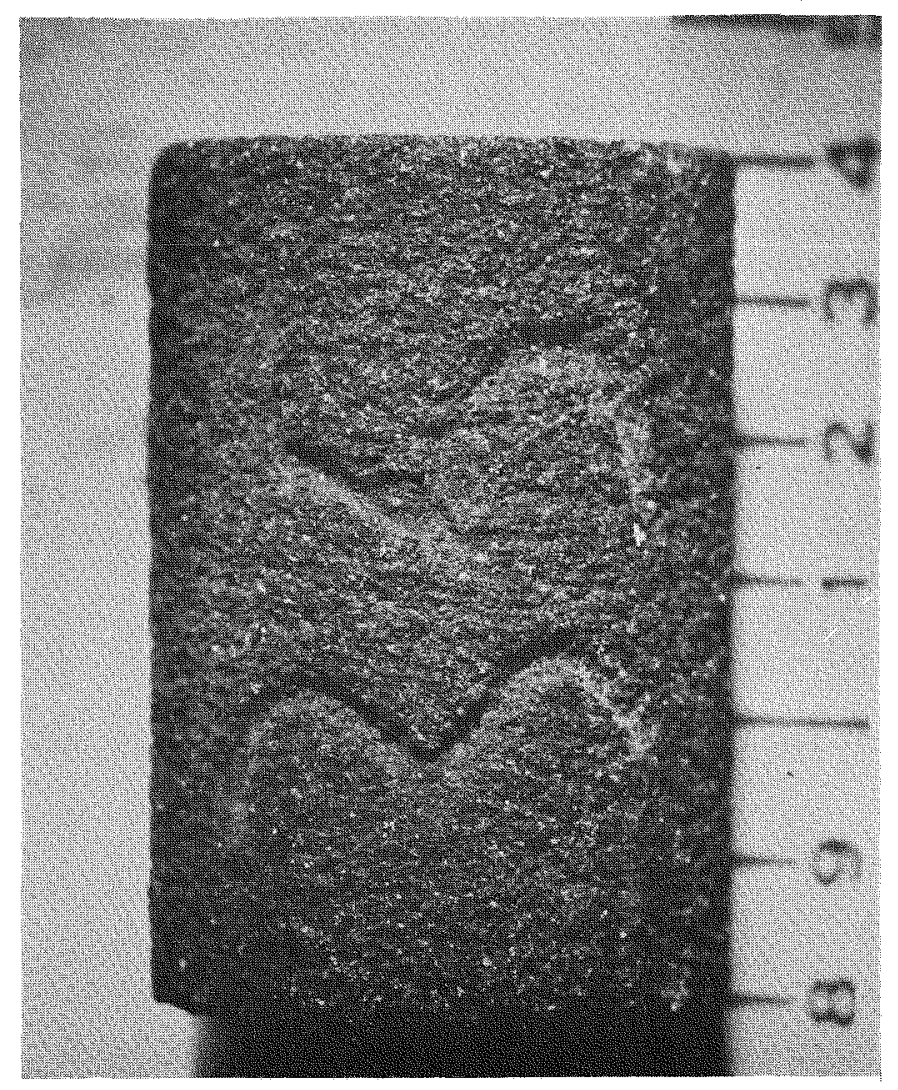

(Side)

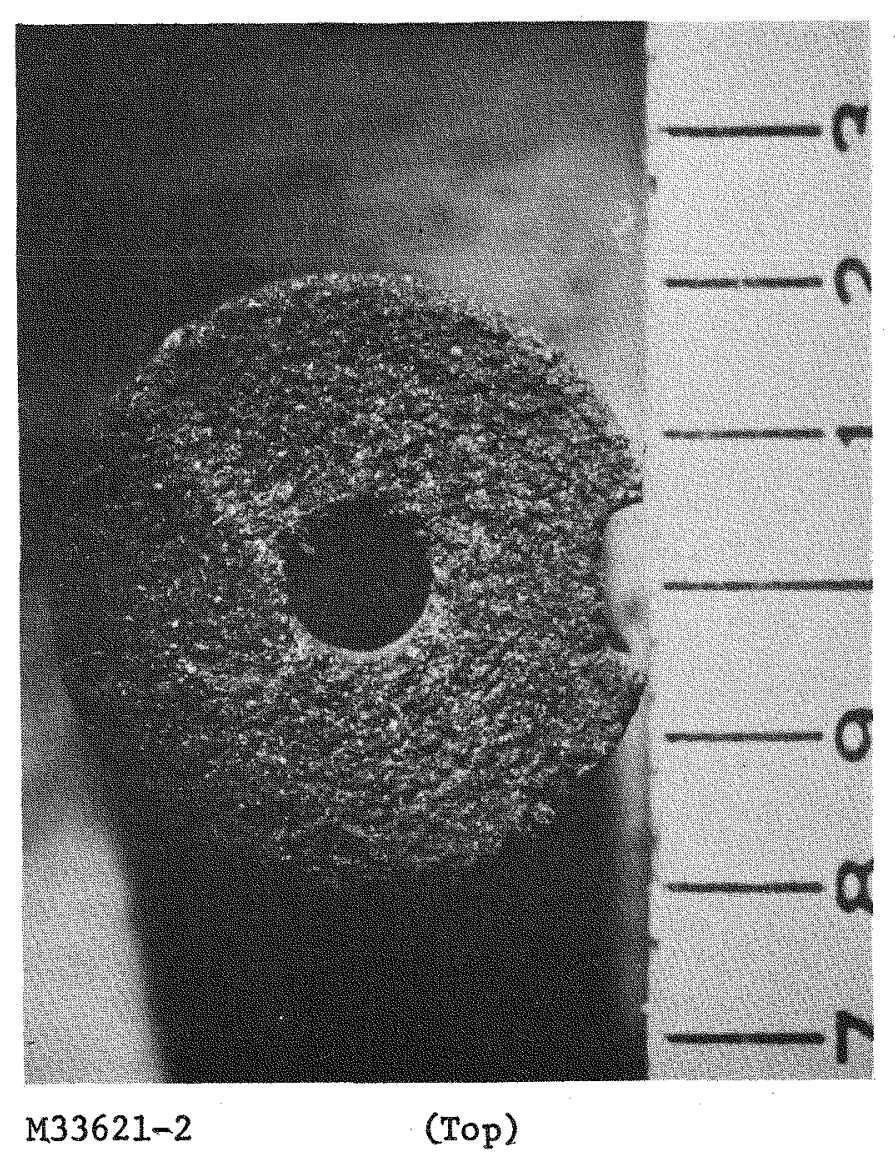

M33621-2

(Top)

Fig. 11.13. Warm-pressed boronated graphite (material 4465-24, specimen 3-5) control rod absorber material containing $0.69 \mathrm{~g}$ natural $\mathrm{B} / \mathrm{cm}^{3}$ and irradiated at $700 \pm 50^{\circ} \mathrm{C}$ to a fast-neutron exposure of $5.3 \times 10^{21} \mathrm{n} / \mathrm{cm}^{2}$ ( $\mathrm{E}>0.18 \mathrm{Mev}$ ) in capsule $\mathrm{BG}-2$ 
The boronated graphite made with B-10-enriched boron powder (4465-24) showed irregular granules of porous $\mathrm{B}_{4} \mathrm{C}$ in a matrix of graphite. The $\mathrm{B}_{4} \mathrm{C}$ was formed in situ from boron powder and graphite matrix. The microstructure of the $\mathrm{B}_{4} \mathrm{C}$ was unchanged by irradiation. An example of the microstructure is shown in Fig. 11.14. This observation, along with the low volume loading of $\mathrm{B}_{4} \mathrm{C}(<\%)$, was taken as evidence that the observed irradiation-induced dimensional change in this material was due primarily to damage in the graphite matrix rather than swelling of the $\mathrm{B}_{4} \mathrm{C}$.

The boronated graphite made with $\mathrm{B}-10$-enriched $\mathrm{B}_{4} \mathrm{C}(4465-26)$ showed a change in microstructure during irradiation. Before irradiation the $\mathrm{B}_{4} \mathrm{C}$ was laced with carbon precipitates. After irradiation the $\mathrm{B}_{4} \mathrm{C}$ granules appeared to have fractured along the precipitates. In addition, the remaining carbon within the $\mathrm{B}_{4} \mathrm{C}$ showed high optical anisotropy and gave the appearance of having expanded in one direction to cause cracking of the $\mathrm{B}_{4} \mathrm{C}$. There was an accompanying shrinkage in the opposite direction, which is consistent with the expected irradiation performance of graphite. An example of this kind of microstructure is shown in Figs. 11.15 and 11.16.

The observed fracturing of the $\mathrm{B}_{4} \mathrm{C}$ could give rise of significant swelling. If the speculation above were correct, the swelling might be reduced by the use of $\mathrm{B}_{4} \mathrm{C}$ having no excess carbon precipitates.

HAFNATED GRAPHITE

The hafnated graphite specimens were unchanged in appearance by irradiation as reported and shown in earlier quarter1y reports GA-10288 and GA-10399. An unirradiated specimen typical of specimens baked at $2000^{\circ}$ and $2600^{\circ} \mathrm{C}$ is shown in Fig. 11.17 .

The microstructure of the hafnated graphite was unchanged by irradiation. An example of a microstructure typical for both materials (4065-132-2000 and 4065-132-2600) is shown in Fig. 11.18. 


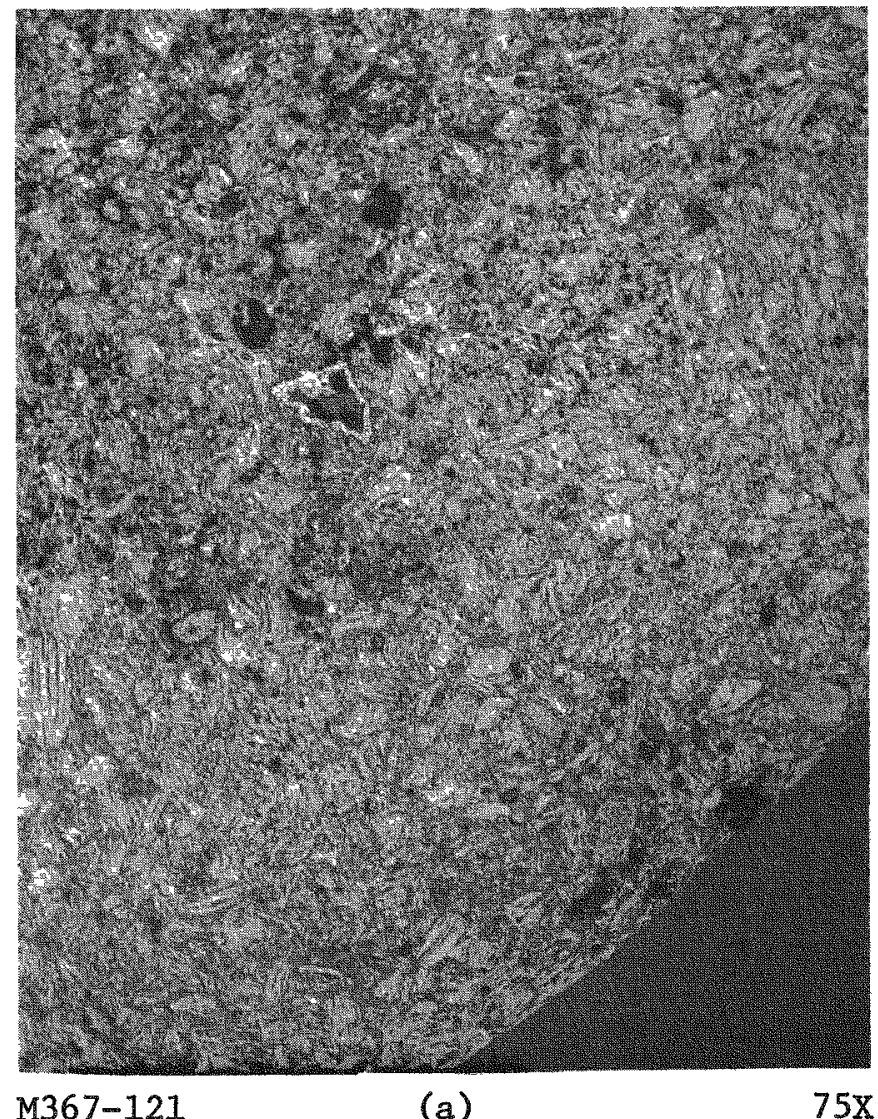

(a)

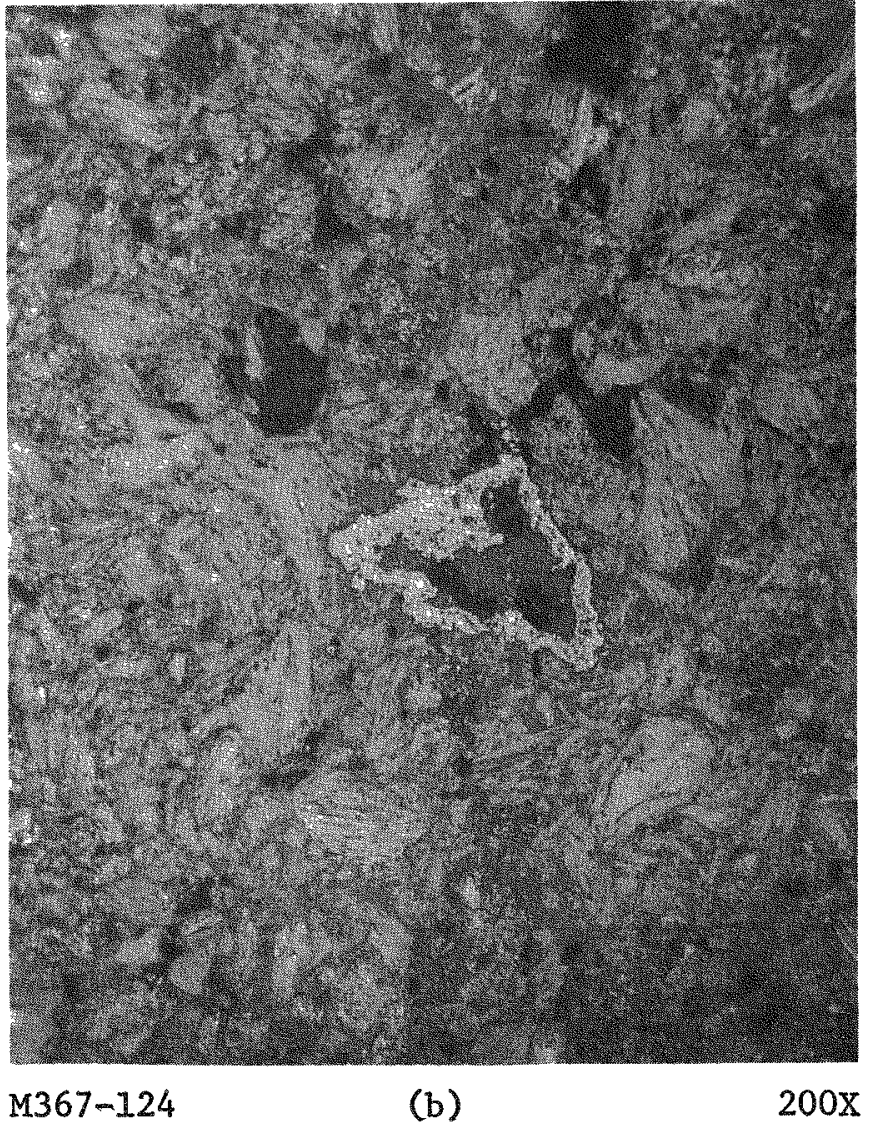

(b)

$200 \mathrm{x}$

Fig. 11.14. Microstructure of boronated graphite (material 4465-24, specimen 4-4) made with 92\% B-10enriched boron powder irradiated in $B G-2$ at $700^{\circ} \mathrm{C}$ to a fast-neutron exposure of 4.4 to $4.7 \times 10^{21} \mathrm{n} / \mathrm{cm}^{2}$ ( $E>0.18 \mathrm{Mev}$ ). The area shown (a) is from the side of the specimen exposed to thermal neutrons and had a $B-10$ burnup of $76 \%$. Irregular inclusion shown at higher magnification (b) was apparently $\mathrm{B}_{4} \mathrm{C}$ converted in situ from matrix and boron powder during $2000^{\circ} \mathrm{C}$ heat treatment. No change in microstructure of the matrix or inclusions were detected as a result of irradiation 


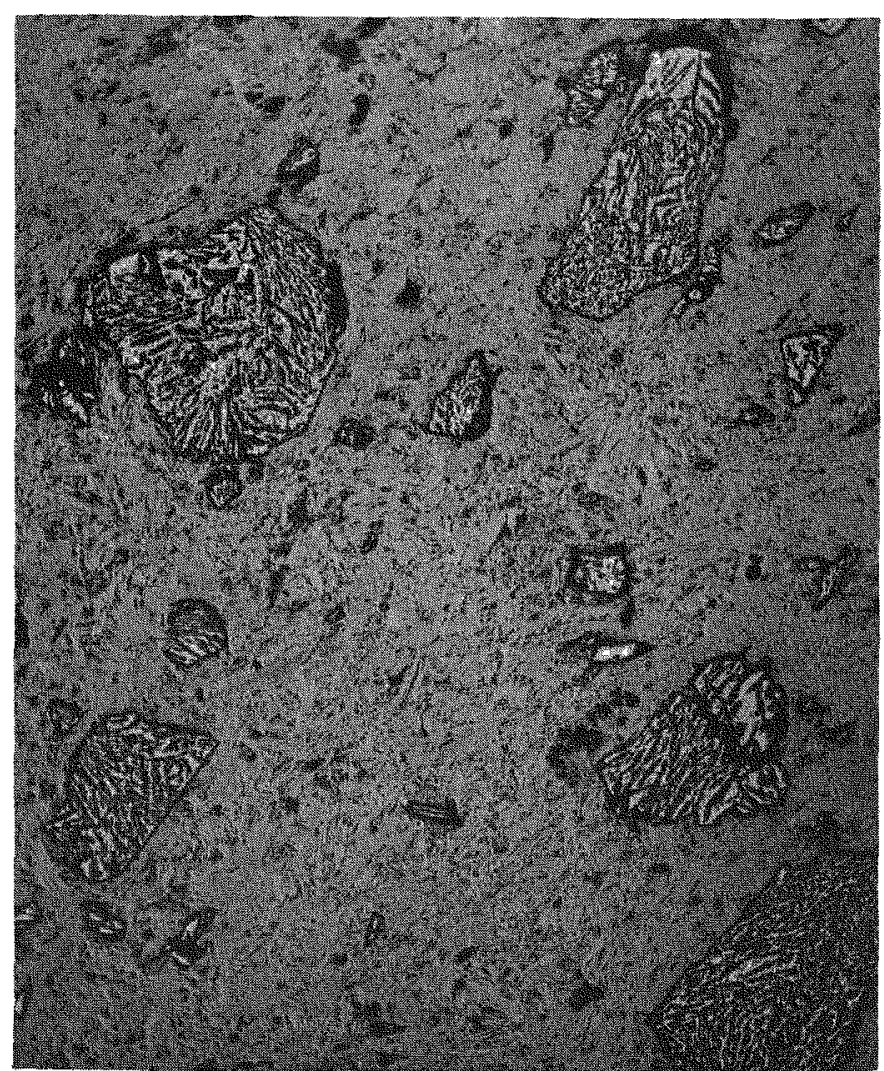

M29736-1 (a)
$75 x$

Fig. 11.15. Microstructure of boronated graphite (material 4465-26, specimen 4-7) made with B-10-enriched $B_{4} C$ (see Fig. 11.16): (a) Before irradiation, low magnification; (b) preirradiation microstructure of $\mathrm{B}_{4} \mathrm{C}$ grains showing excess carbon precipitated within the grain

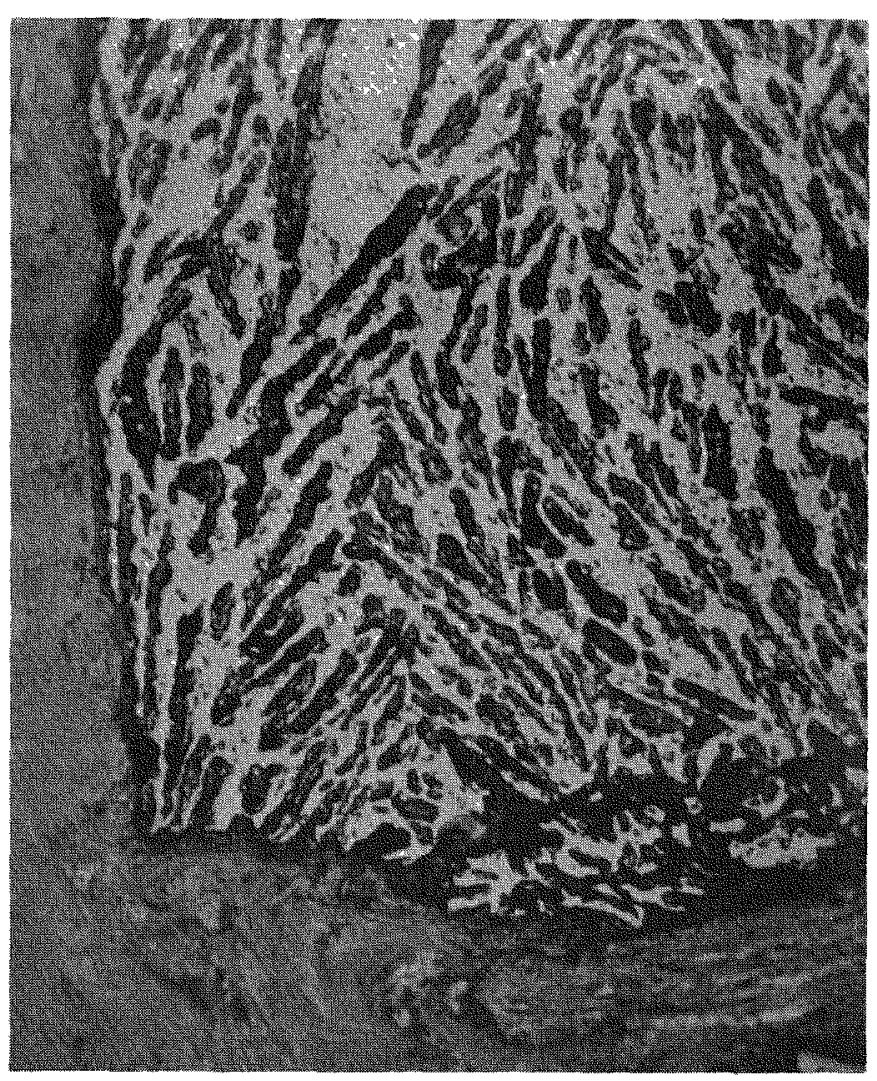

M29736-4

$500 \mathrm{x}$ 


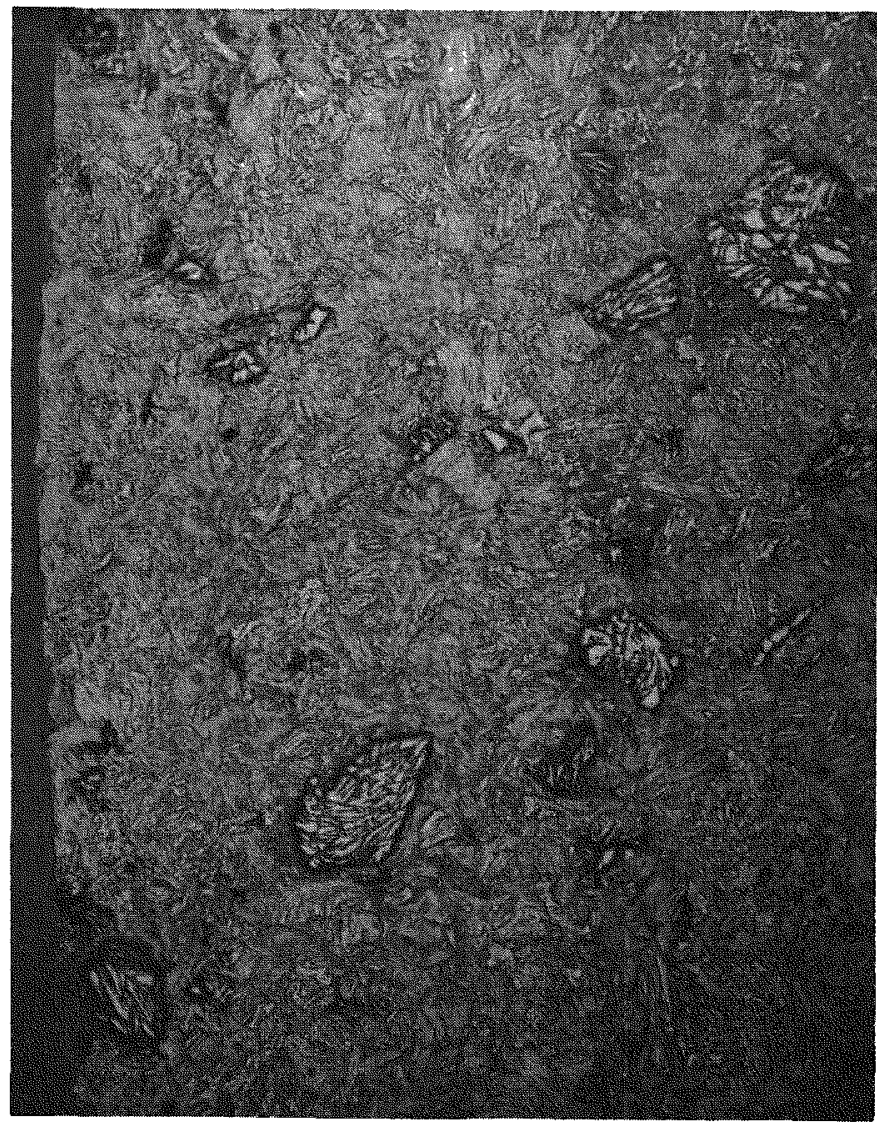

M367-107 (a)
$75 \mathrm{X}$

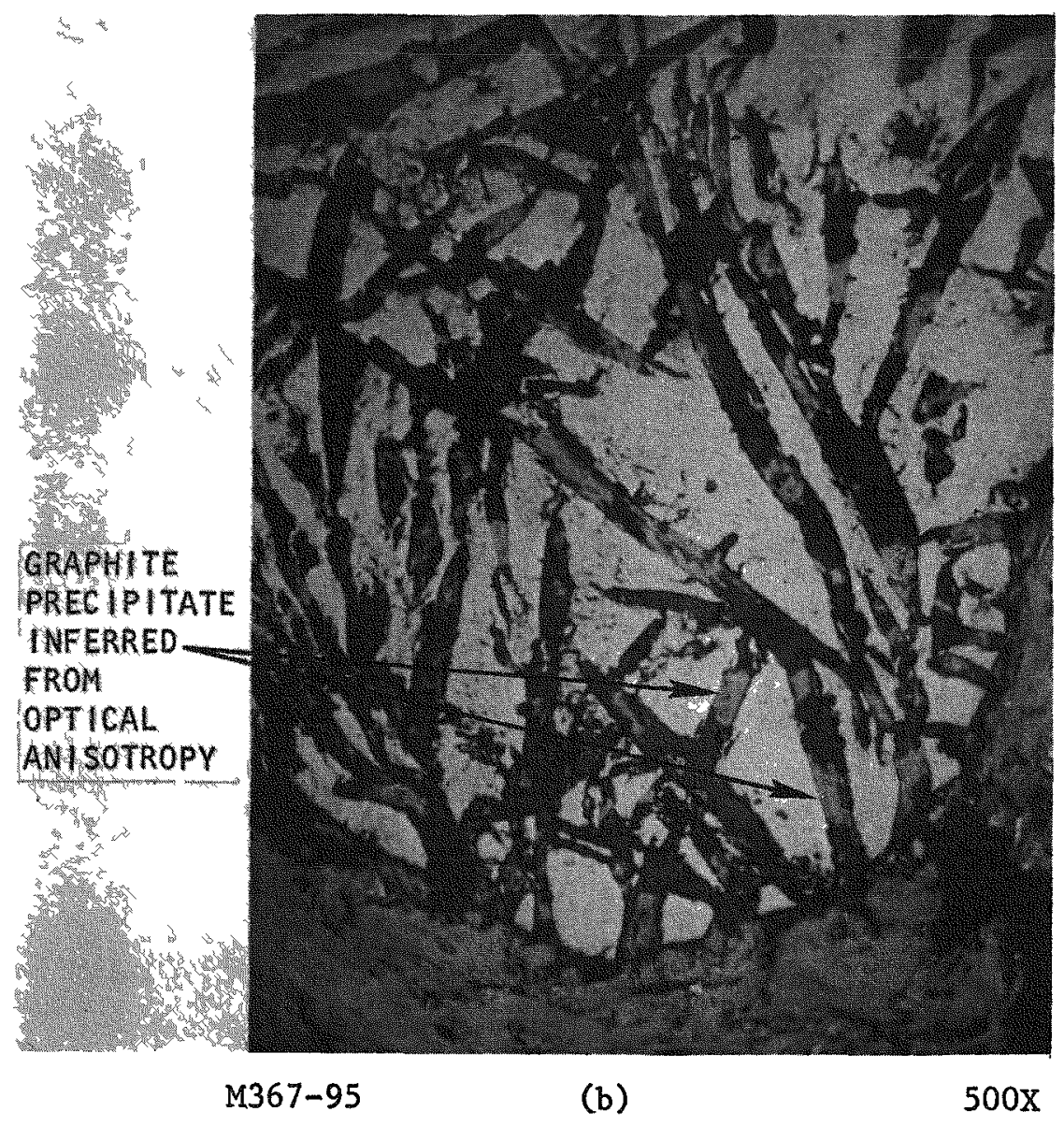

(b)

$500 \mathrm{x}$

Flg. 11.16. Microstructure of boronated graphite (material 4465-26, specimen 4-7) made with B-10-enriched $\mathrm{B}_{4} \mathrm{C}$ (see Fig. 11.15): (a) After irradiation in $B G-2$ at $700^{\circ} \mathrm{C}$ to a fast-neutron exposure of $3.8 \times 10^{21} \mathrm{n} / \mathrm{cm}^{2}(\mathrm{E}>0.18 \mathrm{Mev})$ and $\mathrm{B}-10$ depletion of $31 \%$ (shielded side); (b) postirradiation microstructure of $\mathrm{B}_{4} \mathrm{C}$ grains showing fracturing of grain along graphite precipitates which have apparently undergone dimensional change during irradiation perhaps leading to grain fracture (note areas showing graphite precipitates inferred from optical anisotropy) 


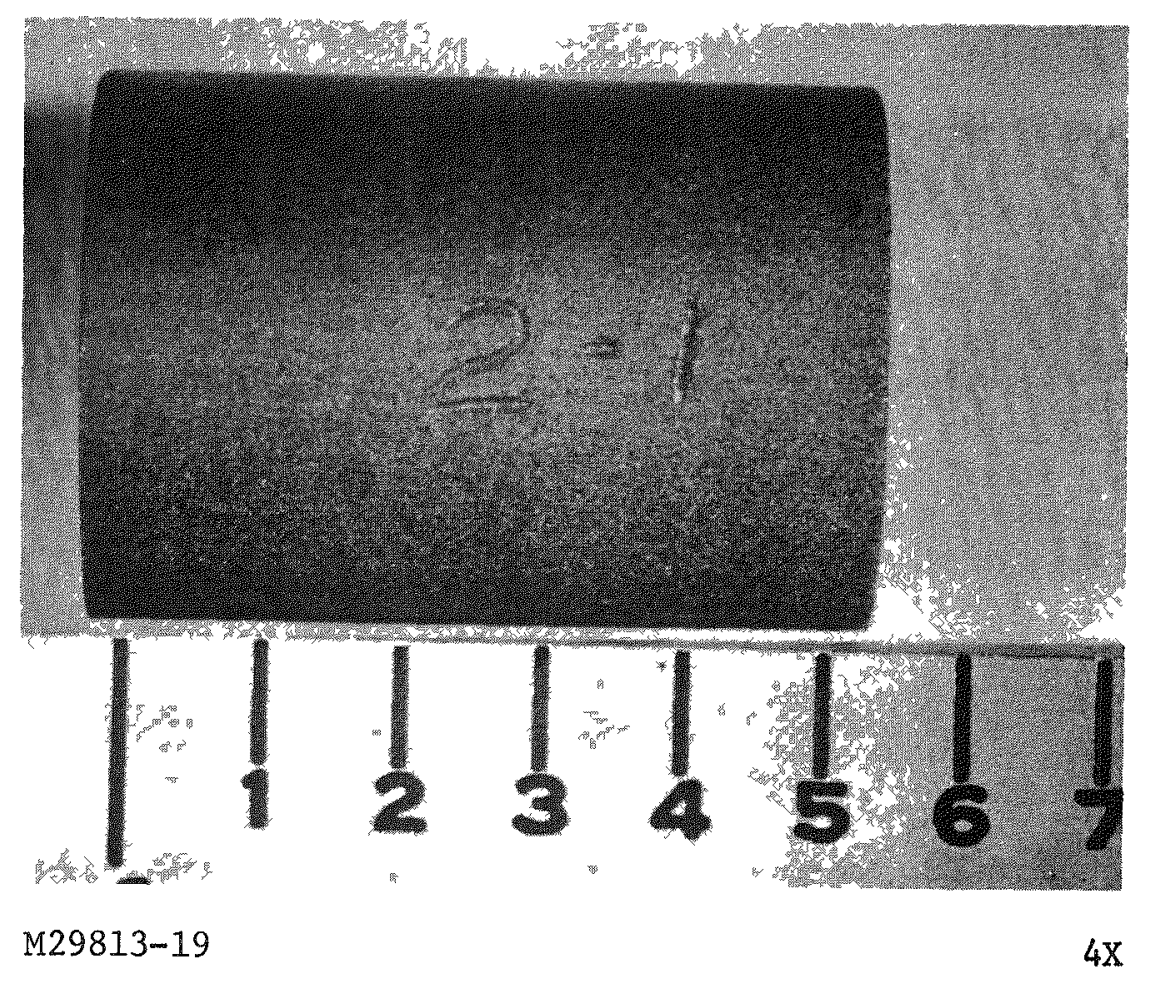

Fig. 11.17. Cylindrical specimen of hafnated graphite, HfC + graphite (material 4065-132-2600), before irradiation in capsule BG-2 

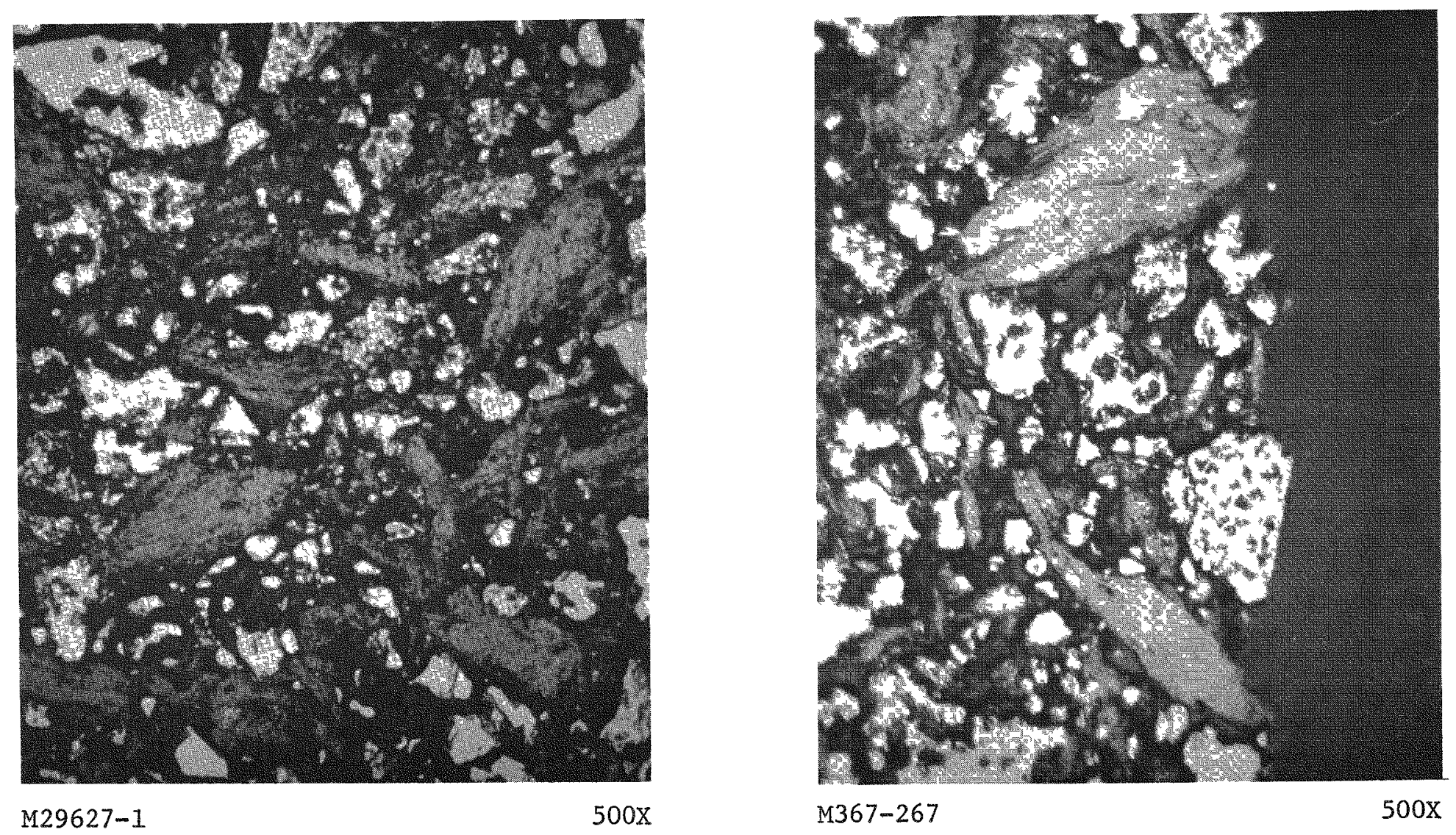

Fig. 11.18. Microstructure of hafnated graphite material 4065-132-2000: (a) before irradiation showing HfC grains in a graphite matrix; (b) after irradiation in $B G-2$ at $700^{\circ} \mathrm{C}$ to a neutron exposure of 3.0 to $6.0 \times 10^{21} \mathrm{n} / \mathrm{cm}^{2}$ ( $\left.\mathrm{E}>0.18 \mathrm{Mev}\right)$, exposed side, showing no obvious change during irradiation 
PIGGYBACK SPECIMENS

The preparation and description of the piggyback specimens has been given in an earlier quarterly report (GA-9660).

\section{Boron Carbide}

The boron carbide piggyback specimens are described in Table 11.3. Not all of the granular samples could be examined after irradiation because of the small amount of material retrieved from the graphite crucibles. However, a sample of each material was obtained and a pre- and postirradiation photograph of the various samples is shown in Figs. 11.19 through 11.23.

The original shapes of both the granular and spherical particles were maintained, although there was evidence of fracturing and reduction in grain size of the $\mathrm{B}-10$-enriched $\mathrm{B}_{4} \mathrm{C}(4465-7)$.

Isotopic analysis for $B-10$ and $B-11$ was obtaired for selected samples and the B-10 depletion of all samples was estimated from the relationship shown in Fig. 11.24. The density distribution of granules of irradiated and unirradiated $\mathrm{B}_{4} \mathrm{C}$ samples was measured in a liquid-density-gradient column made from a mixture of benzene and methylene lodide. The two liquids were added to a graduated burrette so that a stable, approximately linear decrease in liquid density with increasing height in the burrette was created.

Glass beads with known densities from 2.00 to $2.59 \mathrm{~g} / \mathrm{cm}^{3}$ were dropped into the liquid column to calibrate the system. The granular $\mathrm{B}_{4} \mathrm{C}$ samples containing 50 to 200 grains were then added individually and allowed to come to rest at the column height containing the same liquid density as the $\mathrm{B}_{4} \mathrm{C}$ grain. The individual grains were then counted and their density recorded so that a maximum, minimum, and mean $\mathrm{B}_{4} \mathrm{C}$ density could be determined. A new liquid column was used for each sample. The results of this work are shown in Table 11.4 . 
TABLE 11.3

PIGGYBACK SAMPLES IRRADIATED IN CAPSULE BG-2

\begin{tabular}{|c|c|c|c|c|}
\hline $\begin{array}{l}\text { Materia1 } \\
\text { No. } \\
\end{array}$ & Description & $\begin{array}{c}\text { Partiele } \\
\text { Size } \\
\text { Range } \\
\text { (Mesh Size) } \\
\end{array}$ & $\begin{array}{c}\text { Preirradiation } \\
\text { Density } \\
\text { Range of } \\
\text { Samples } \\
\left(\mathrm{g} / \mathrm{cm}^{3}\right) \\
\end{array}$ & $\begin{array}{l}\text { Major } \\
\text { Impurities }\end{array}$ \\
\hline $4065-84$ & $\begin{array}{l}\mathrm{B}_{4} \mathrm{C}, \text { Commercial, high } \\
\text { purity }(76 \mathrm{wt}-\% \mathrm{~B})\end{array}$ & $-48+140$ & $>2.43>2.52$ & $\begin{array}{l}0.1 \text { wt-\% Fe; } 1 \\
\text { wt-\% } \mathrm{B}_{2} \mathrm{O}_{3} ; \text { Trace } \\
\text { elements, ppm: } \\
\text { A1 200, Ca } 300, \\
\text { V } 300, \mathrm{Zr} 400\end{array}$ \\
\hline $3685-84$ & $\begin{array}{l}\mathrm{B}_{4} \mathrm{C} \text {, Commercial } \\
\text { Technical grade (70 wt }-\% \mathrm{~B})\end{array}$ & $-50+140$ & $>2.43>2.52$ & $\begin{array}{l}0.1 \mathrm{wt}-\% \mathrm{Fe}, 0.2 \\
\text { wt }-\% \mathrm{~B}_{2} \mathrm{O}_{3}\end{array}$ \\
\hline $3685-4$ & $\begin{array}{l}\mathrm{B}_{4} \mathrm{C}, \text { spherical, from oRNL } \\
(82 \mathrm{wt}-\% \mathrm{~B})\end{array}$ & $-210+149^{(a)}$ & $>2.39>2.54$ & $\begin{array}{l}\text { Trace elements, } \\
\text { ppm: Cu } 200, \mathrm{~A} 1 \\
\text { 100, Fe } 10, \mathrm{~V} \\
200, \text { Si } 600\end{array}$ \\
\hline $4465-7$ & $\begin{array}{l}\mathrm{B}_{4} \mathrm{C} \text {, made from } \mathrm{B}-10 \text {-enriched } \\
\mathrm{P}(92 \% \mathrm{~B} 10) 69 \text { wt }-\% \mathrm{~B}\end{array}$ & $-48+200$ & $>2.27>2.36$ & $\begin{array}{l}0.03 \mathrm{wt}-\% \mathrm{~B}_{2} \mathrm{O}_{3} ; \\
\text { Trace impurities } \\
\text { ppm: } \mathrm{Ni} 2000 \\
\text { Si } 400, \mathrm{Ca} 400 \\
\text { Fe } 200\end{array}$ \\
\hline $3685-10$ & $\begin{array}{l}\mathrm{B}_{4} \mathrm{C} \text {, made from } \mathrm{B}-10 \text {-depleted } \\
\mathrm{B}(1.5 \text { at }-\% \text { B-10 }\end{array}$ & $-50+140$ & $>2.42>2.56$ & $\begin{array}{l}0.1 \mathrm{wt}-\% \mathrm{Fe}, \\
0.06 \mathrm{wt}-\% \mathrm{~B}_{2} \mathrm{O}_{3}\end{array}$ \\
\hline
\end{tabular}




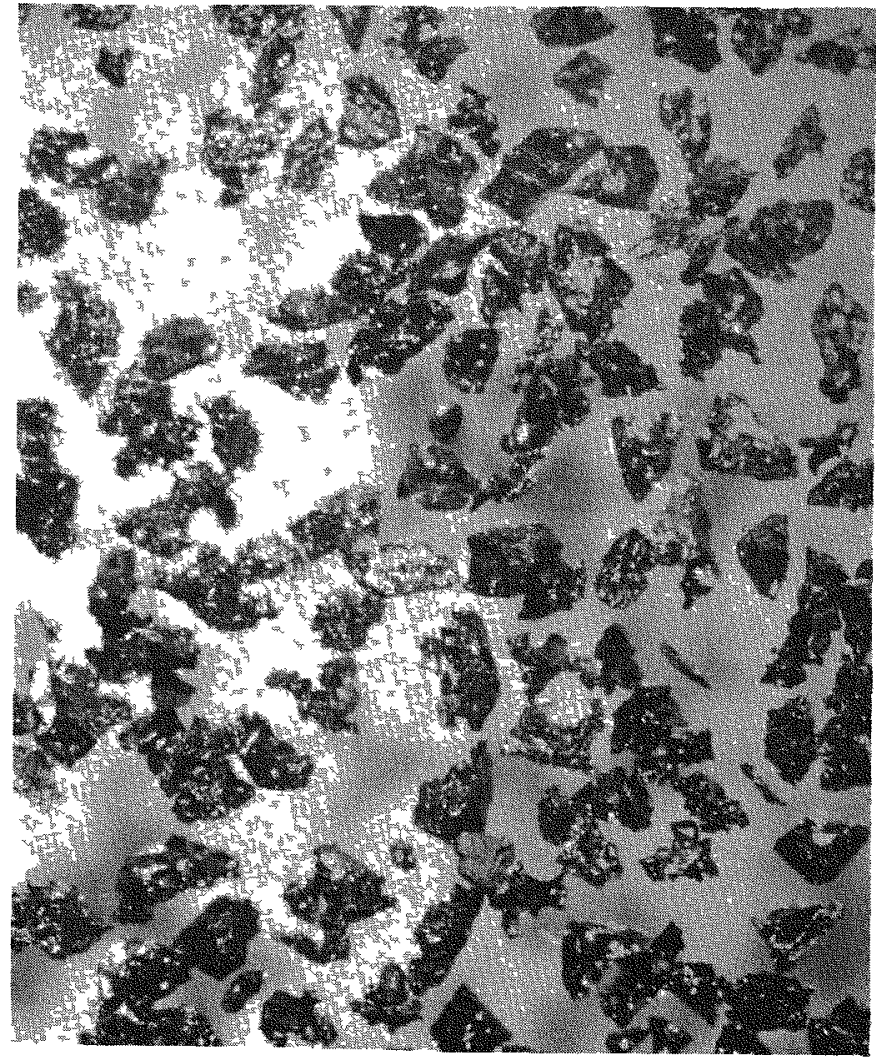

M33891-1

(a)

$22 \mathrm{X}$

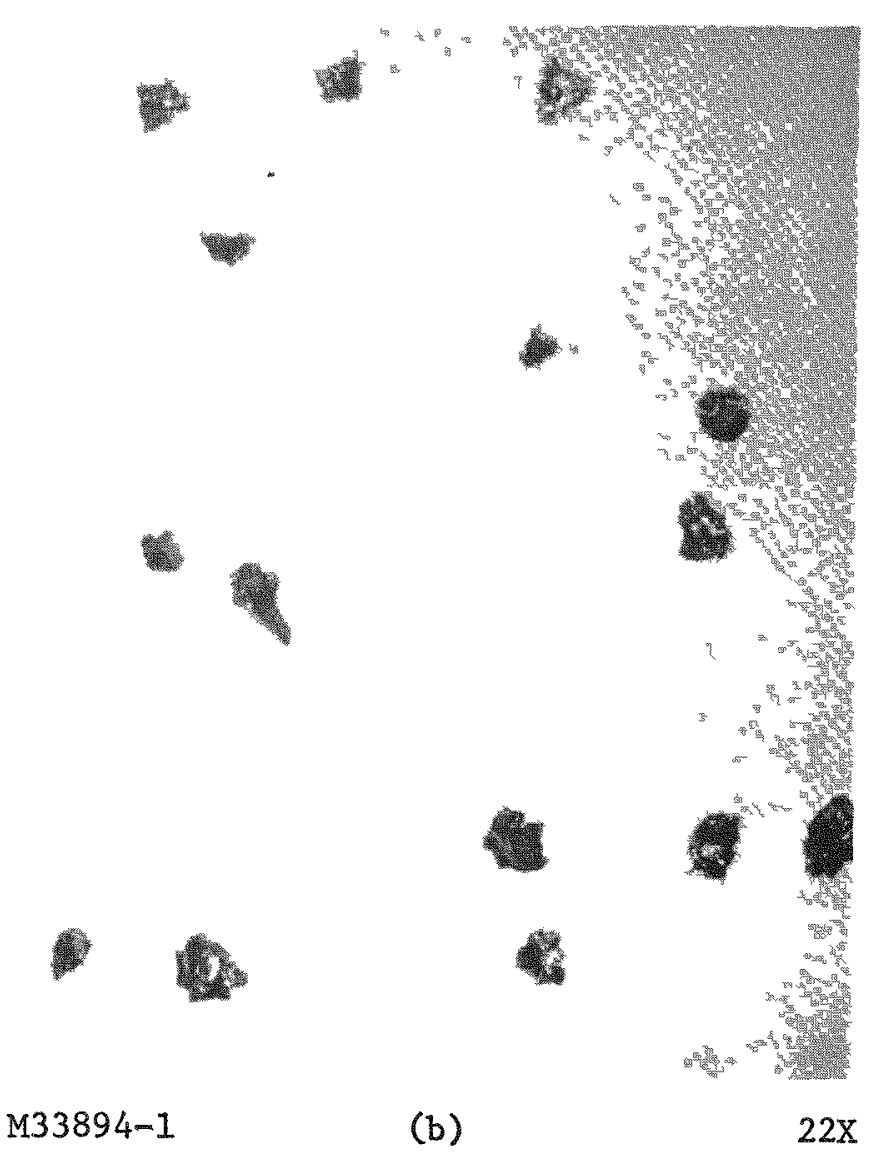

Fig. 11.19. Boron carbide (high boron, $76 \mathrm{wt}-\%$ B, material 4065-84, specimen 1-6): (a) before irradiation; (b) after irradiation in $B G-2$ at $500^{\circ} \mathrm{C} \pm 50$ to a fast-neutron fluence of $4.8 \times 10^{21} \mathrm{n} / \mathrm{cm}^{2}$ (E $>0.18 \mathrm{Mev}$ ) and B-10 burnup of $61 \%$ 

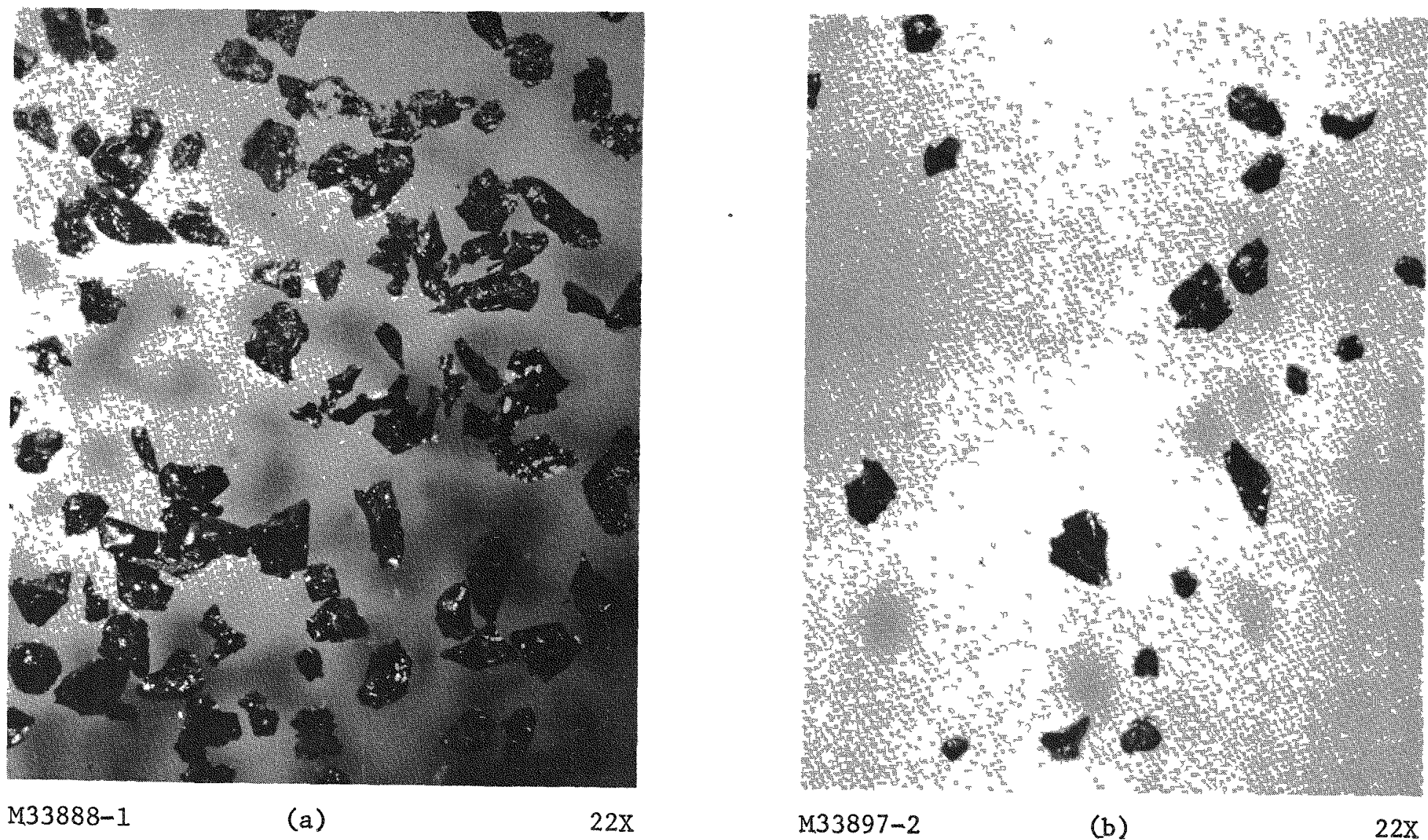

Fig. 11.20. Boron carbide (technical grade, 70 wt-\% B, material 3685-84, specimen 3-4): (a) before irradiation; (b) after irradiation at $500 \pm 50^{\circ} \mathrm{C}$ to a fast-neutron fluence of $5.8 \times 10^{21}$ $\mathrm{n} / \mathrm{cm}^{2}(\mathrm{E}>0.18 \mathrm{Mev})$ and a $\mathrm{B}-10$ burnup of $94 \%$ 

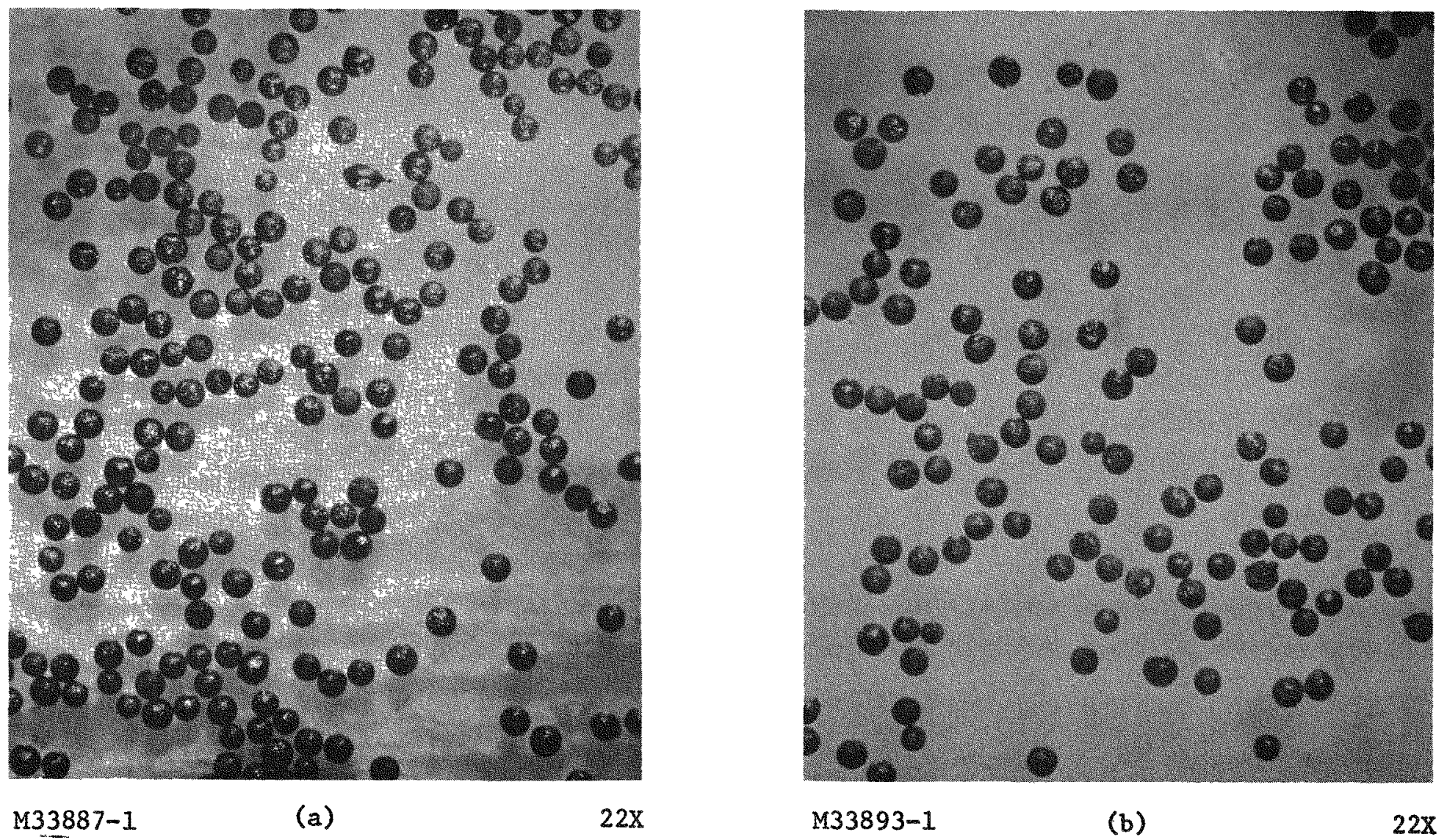

Fig. 11.21. Spherical $B_{4} C$ granules (material 3685-4, specimen IIF): (a) before irradiation; (b) after irradiation as loose granules in $\mathrm{BG}-2$ at approximately $450 \pm 50^{\circ} \mathrm{C}$ to a fast-neutron fluence of $3.4 \times 10^{21} \mathrm{n} / \mathrm{cm}^{2}(\mathrm{E}>0.18 \mathrm{Mev})$ and $\mathrm{B}-10$ burnup of $76 \%$ 


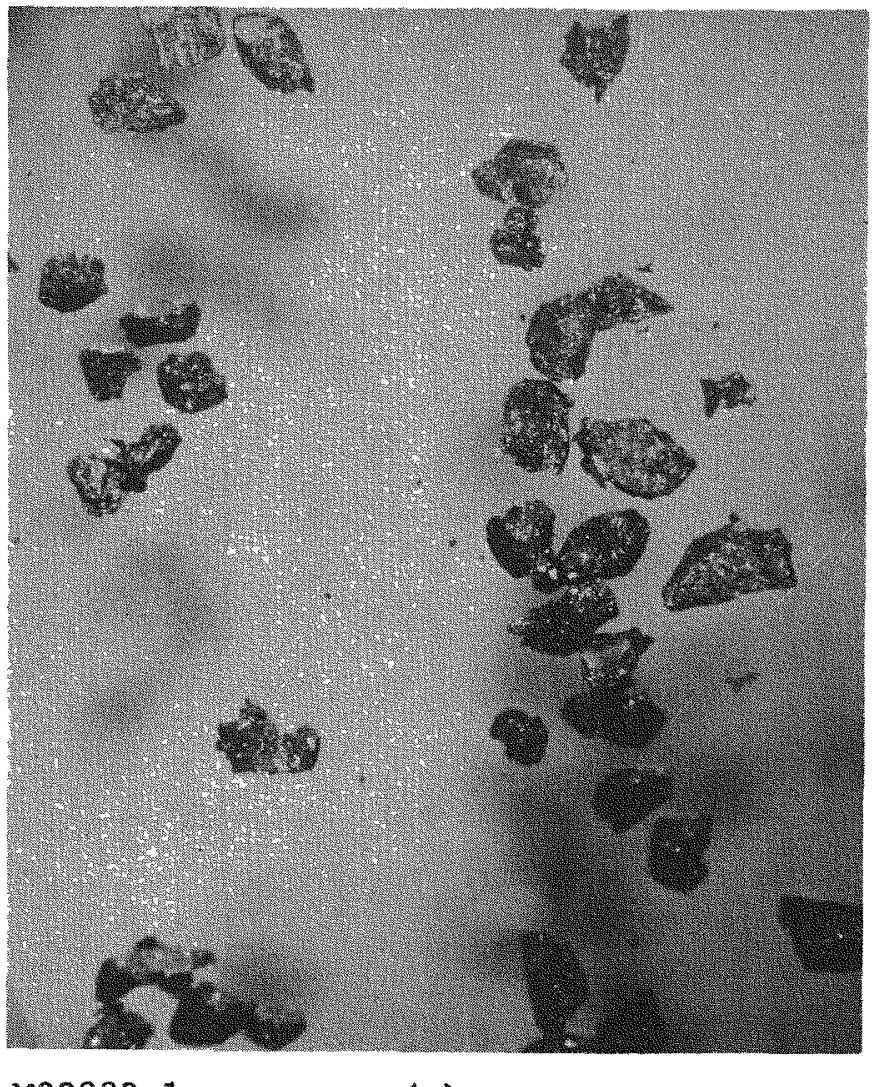

(a)
$22 \mathrm{X}$

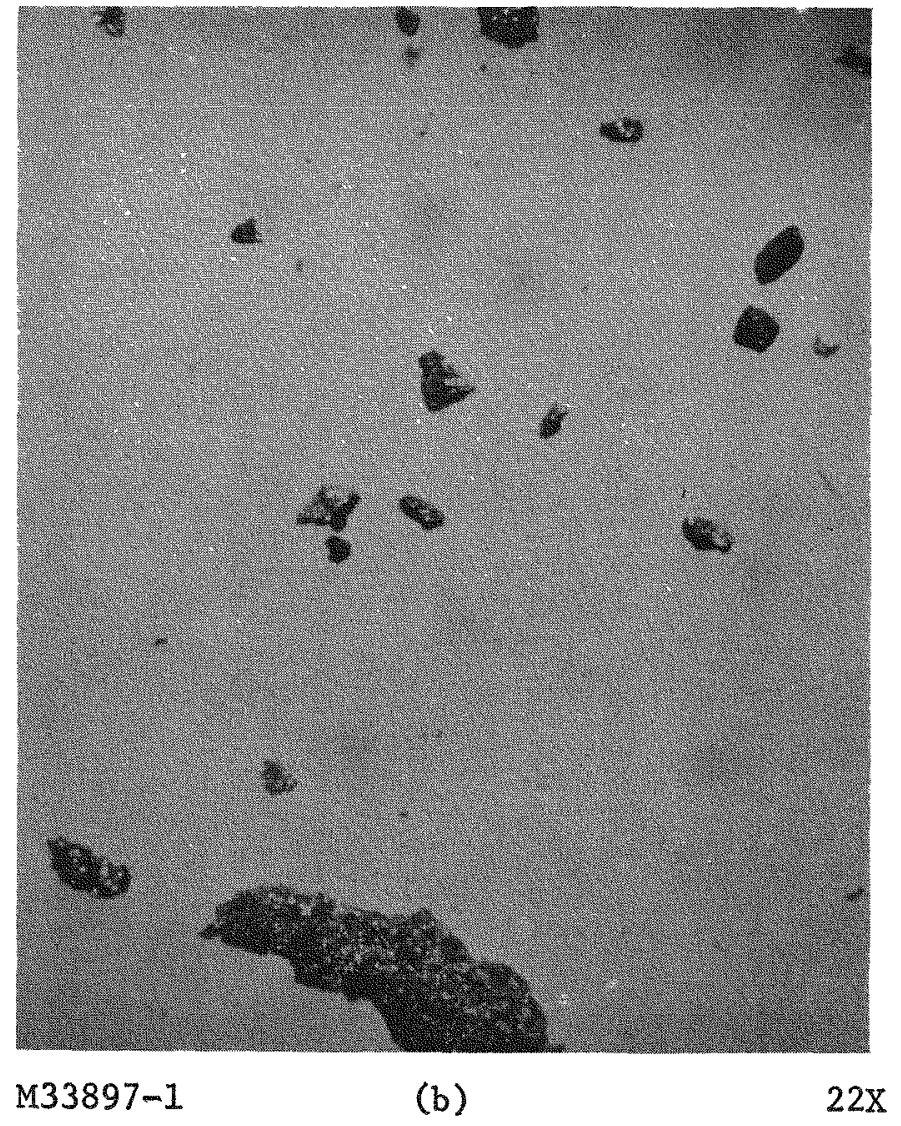

M33897-1

(b)

$22 \mathrm{X}$

Fig. 11.22. Boron carbide (material 4465-7, specimen 33F) made from $B-10$ enriched boron $(B-10 / B-11=11.5)$ : (a) before irradiation; (b) after irradiation in $\mathrm{BG}-2$ at $500 \pm 50^{\circ} \mathrm{C}$ to a fast-neutron exposure of $5.9 \times 10^{21 \mathrm{n} / \mathrm{cm}^{2}}(\mathrm{E}>0.18 \mathrm{Mev})$ and $\mathrm{B}-10$ burnup of $94 \%$. Much of the irradiated sample was apparently turned to fine powder and lost. The largest granule in (b) was a piece of graphite debris from the crucible 


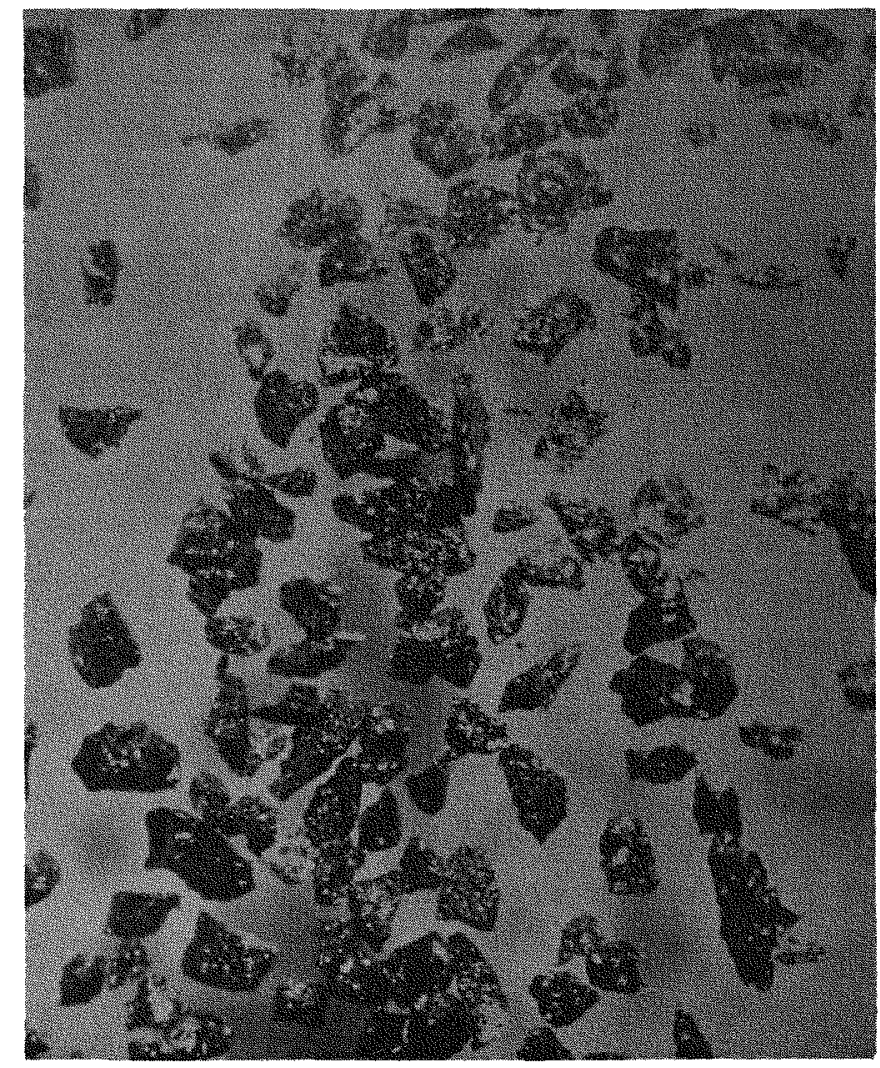

M33890-1

(a)

$22 \mathrm{X}$

Fig. 11.23. Boron carbide (material 3685-105, specimen 31F) made from $B-10$ depleted boron $(B-10 / B-11=$
$0.015)$ : (a) before irradiation; (b) after irradiation in $B G-2$ at $500 \pm 50^{\circ} \mathrm{C}$ to a fast-neutron

Fig. 11.23. Boron carbide (material 3685-105, specimen $31 F$ ) made from $B-10$ depleted boron $(B-10 / B-11=$
0.015 ): (a) before irradiation; (b) after irradiation in $B G-2$ at $500 \pm 50^{\circ} \mathrm{C}$ to a fast-neutron fluence of $6.0 \times 10^{21} \mathrm{n} / \mathrm{cm}^{2}(\mathrm{E}>0.18 \mathrm{Mev})$ and a thermal fluence estimated at approximately $3 \times 10^{21}(\mathrm{E}<0.4 \mathrm{ev})$
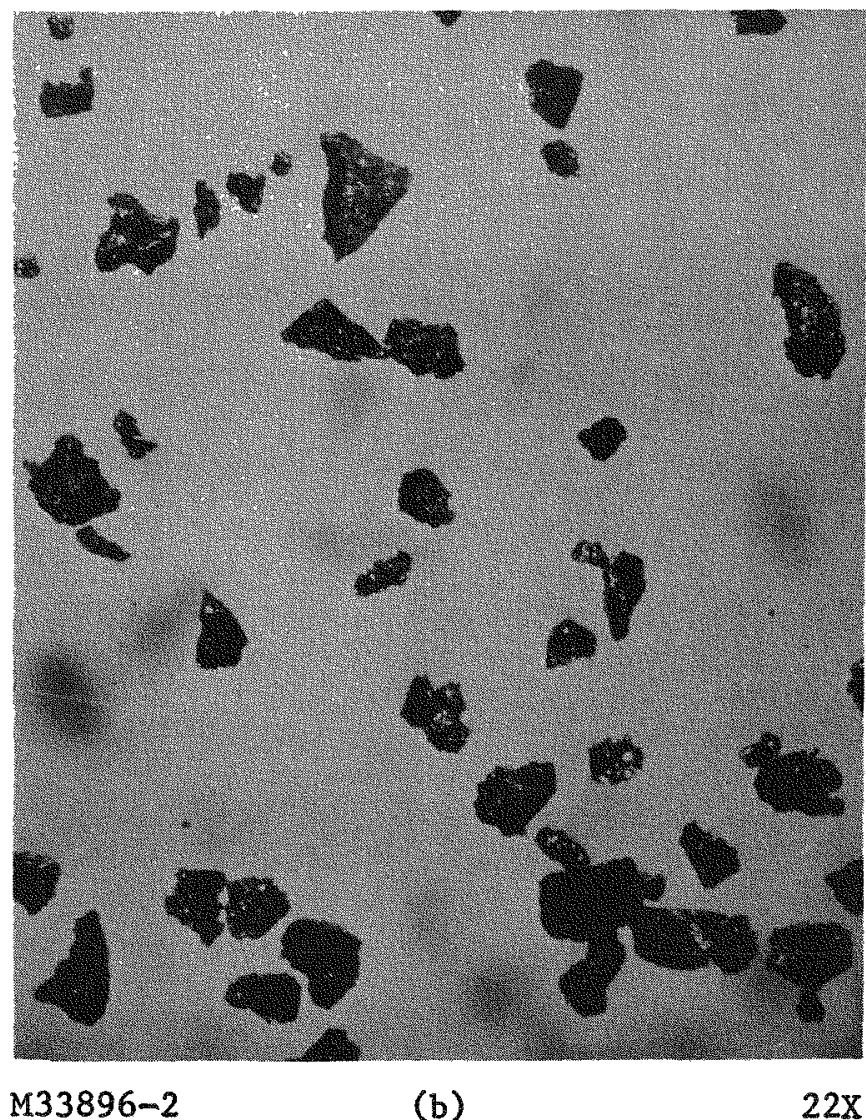

$22 \mathrm{X}$ 


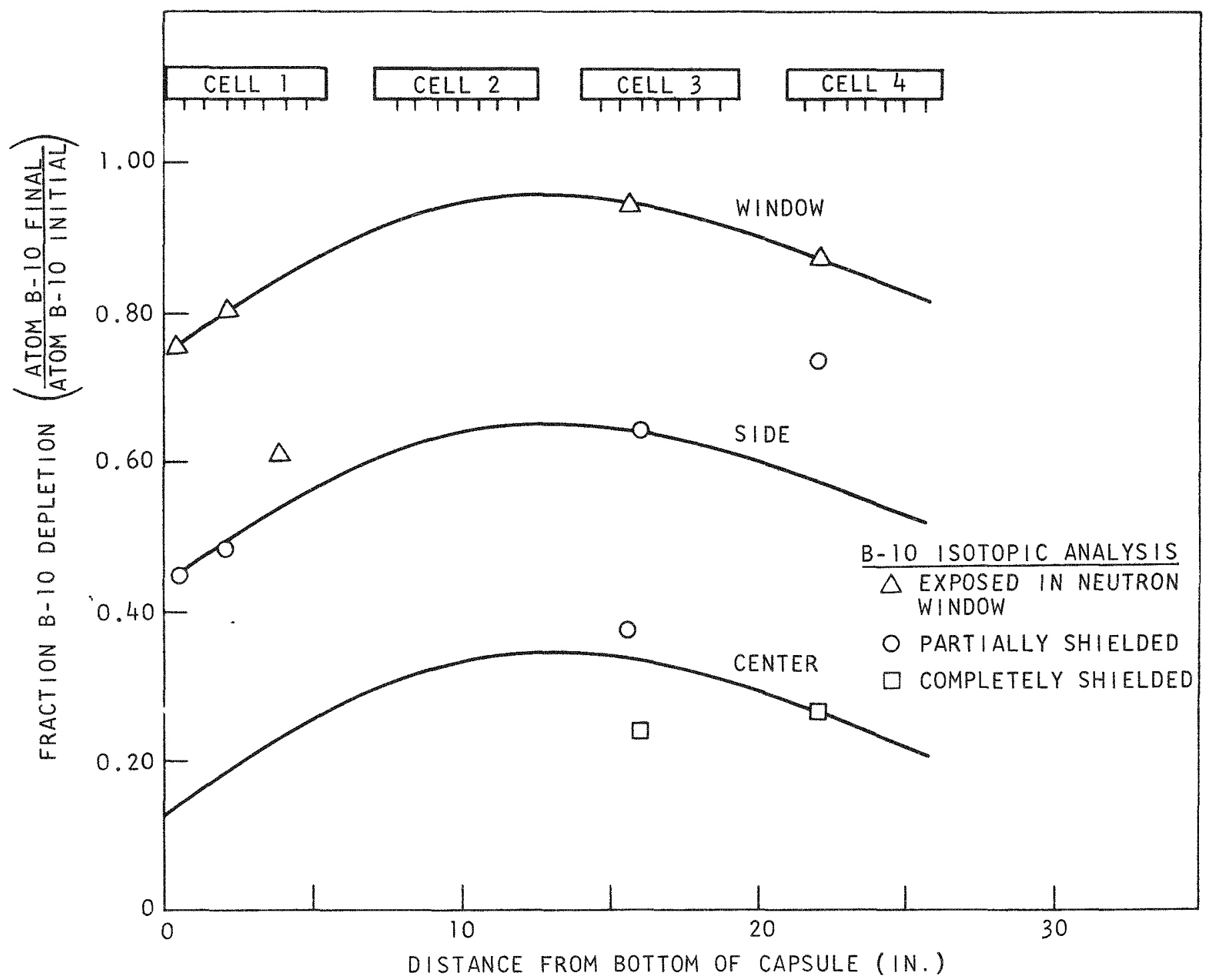

Fig. 11.24. B-10 burnout profile for $\mathrm{B}_{4} \mathrm{C}$ piggyback samples in capsule $\mathrm{BG}-2$ 
TABLE 11.4

SUMMARY OF BG -2 PIGGYBACK SPECIMEN RESULTS

\begin{tabular}{|c|c|c|c|c|c|c|c|c|c|c|c|}
\hline \multirow{2}{*}{$\begin{array}{c}\text { Sample } \\
\text { Material } \\
\text { Number } \\
\end{array}$} & \multirow[b]{2}{*}{ Description } & \multirow[b]{2}{*}{ Cell } & \multirow[b]{2}{*}{ Cructble } & \multirow[b]{2}{*}{ Position } & \multirow[t]{2}{*}{$\begin{array}{l}\text { Fast } \\
\text { Neutron } \\
\text { Exposure } \\
\times 10^{21} \\
(E>0.18 \mathrm{Mev})\end{array}$} & \multirow{2}{*}{$\begin{array}{l}\text { Irrad } \\
\text { Temp } \\
{ }^{\circ} \mathrm{C} \\
\pm 50\end{array}$} & \multirow{2}{*}{$\begin{array}{l}\text { Fraction } \\
\text { B-10 } \\
\text { Depletion } \\
\text { (d) }\end{array}$} & \multirow[t]{2}{*}{$\begin{array}{c}\mathrm{B}-10 \\
\text { Fisston } \\
\text { Density } \\
\text { B-10Fission } \\
\mathrm{cm}^{3} \mathrm{~B}_{4} \mathrm{C} \\
\times 10^{22}\end{array}$} & \multicolumn{3}{|c|}{ Densicy $\left(\mathrm{g} / \mathrm{cm}^{3}\right)(\mathrm{f})$} \\
\hline & & & & & & & & & Min. & Max. & Mean \\
\hline \multirow[t]{2}{*}{$3685-105$} & $\begin{array}{l}\text { B4C granules } \\
\text { depleted in } \\
B-10\left[\frac{\mathrm{B}-10}{\mathrm{~B}-1 \mathrm{11}}=.015\right]\end{array}$ & $\begin{array}{l}- \\
3 \\
3 \\
3\end{array}$ & $\begin{array}{l}- \\
1 \\
1\end{array}$ & $\begin{array}{l}\text { unirrad } \\
\text { (a) } \\
\text { (b) } \\
\text { (c) }\end{array}$ & $\begin{array}{l}0 \\
6.0 \\
6.0 \\
6.0\end{array}$ & $\begin{array}{l}-7 \\
500 \\
500 \\
700\end{array}$ & $\begin{array}{l}- \\
(\mathrm{g}) \\
(\mathrm{g}) \\
(\mathrm{g})\end{array}$ & $\begin{array}{l}0 \\
0 \\
0 \\
0\end{array}$ & $\begin{array}{l}2.42 \\
2.40 \\
2.43 \\
2.44\end{array}$ & $\begin{array}{l}2.56 \\
2.51 \\
2.51 \\
2.52\end{array}$ & $\begin{array}{l}2.50 \\
2.47 \\
2.46 \\
2.48\end{array}$ \\
\hline & & $\begin{array}{l}4 \\
4\end{array}$ & $\begin{array}{l}1 \\
1\end{array}$ & (a) & $\begin{array}{l}4.8 \\
4.8\end{array}$ & $\begin{array}{l}600 \\
600\end{array}$ & $\begin{array}{l}(\mathrm{g}) \\
(\mathrm{g})\end{array}$ & $\begin{array}{l}0 \\
0\end{array}$ & $\begin{array}{l}2.42 \\
2.40\end{array}$ & $\begin{array}{l}2.50 \\
2.50\end{array}$ & $\begin{array}{l}2.45 \\
2.45\end{array}$ \\
\hline \multirow[t]{5}{*}{$3685-4$} & $\begin{array}{l}\text { Sperical } \mathrm{B}_{4} \mathrm{C} \\
\text { Natuxal Boron } \\
82 \mathrm{wt}-\% \text { B }\end{array}$ & $\begin{array}{l}- \\
1 \\
1\end{array}$ & $\begin{array}{l}- \\
1 \\
1\end{array}$ & $\begin{array}{l}\text { unirrad } \\
\text { (b) } \\
\text { (a) }\end{array}$ & $\begin{array}{c}0 \\
3.4 \\
3.4\end{array}$ & $\begin{array}{l}- \\
450 \\
450\end{array}$ & $\begin{array}{l}.45(\mathrm{e}) \\
.76(\mathrm{e})\end{array}$ & $\begin{array}{c}0 \\
1.0 \\
1.7\end{array}$ & $\begin{array}{l}2.39 \\
2.12 \\
2.05\end{array}$ & $\begin{array}{l}2.54 \\
2.38 \\
2.31\end{array}$ & $\begin{array}{l}2.48 \\
2.30 \\
2.19\end{array}$ \\
\hline & & 1 & $\begin{array}{l}2 \\
2\end{array}$ & $\begin{array}{l}\text { (a) } \\
\text { (b) }\end{array}$ & $\begin{array}{l}3.8 \\
3.8\end{array}$ & $\begin{array}{l}450 \\
450\end{array}$ & $\begin{array}{l}.77 \\
.48\end{array}$ & $\begin{array}{l}1.7 \\
1.1\end{array}$ & $\begin{array}{l}2.22 \\
2.13\end{array}$ & $\begin{array}{l}2.37 \\
2.31\end{array}$ & $\begin{array}{l}2.32 \\
2.23\end{array}$ \\
\hline & & $\begin{array}{l}1 \\
1\end{array}$ & $\begin{array}{l}3 \\
3\end{array}$ & $\begin{array}{l}\text { (b) } \\
\text { (a) }\end{array}$ & $\begin{array}{l}4.2 \\
4.2\end{array}$ & $\begin{array}{l}550 \\
550\end{array}$ & $\begin{array}{l}.48 \text { (e) } \\
.81 \text { (e) }\end{array}$ & $\begin{array}{l}1.1 \\
1.8\end{array}$ & $\begin{array}{l}2.19 \\
2.11\end{array}$ & $\begin{array}{l}2.36 \\
2.28\end{array}$ & $\begin{array}{l}2.29 \\
2.25\end{array}$ \\
\hline & & 3 & 6 & (a) & 5.6 & 500 & .93 & 2.1 & 2.10 & 2.26 & 2.18 \\
\hline & & 4 & 6 & (a) & 4.0 & 500 & .84 & 1.9 & 2.15 & 2.35 & 2.24 \\
\hline \multirow[t]{6}{*}{$3685-84$} & $\begin{array}{l}\mathrm{B}_{4} \mathrm{C} \text { granules } \\
\text { Natural Boron } \\
70 \text { wt }-\% \mathrm{~B}\end{array}$ & $\begin{array}{l}- \\
3 \\
3\end{array}$ & $\begin{array}{l}- \\
2 \\
2\end{array}$ & $\begin{array}{l}\text { unirrad } \\
\text { (a) } \\
\text { (b) }\end{array}$ & $\begin{array}{c}0 \\
5.9 \\
5.9\end{array}$ & $\begin{array}{r}- \\
500 \\
500\end{array}$ & $\begin{array}{c}0 \\
.95(e) \\
.38(e)\end{array}$ & $\begin{array}{c}0 \\
1.8 \\
0.7\end{array}$ & $\begin{array}{l}2.43 \\
2.09 \\
2.32\end{array}$ & $\begin{array}{l}2.52 \\
2.21 \\
2.42\end{array}$ & $\begin{array}{l}2.50 \\
2.14 \\
2.37\end{array}$ \\
\hline & & 3 & 4 & (a) & 5.8 & 500 & .94 & 1.8 & 2.12 & 2.18 & 2.15 \\
\hline & & 3 & 5 & (a) & 5.8 & 500 & .93 & 1.8 & 2.09 & 2.21 & 2.15 \\
\hline & & $\begin{array}{l}4 \\
4 \\
4\end{array}$ & $\begin{array}{l}2 \\
2 \\
2\end{array}$ & $\begin{array}{l}\text { (a) } \\
\text { (b) } \\
\text { (c) }\end{array}$ & $\begin{array}{l}4.6 \\
4.6 \\
4.6\end{array}$ & $\begin{array}{l}600 \\
600 \\
700\end{array}$ & $\begin{array}{l}.88(\mathrm{e}) \\
.74(\mathrm{e}) \\
.28(\mathrm{e})\end{array}$ & $\begin{array}{l}1.7 \\
1.4 \\
0.5\end{array}$ & $\begin{array}{l}2.05 \\
2.10 \\
2.36\end{array}$ & $\begin{array}{l}2.25 \\
2.28 \\
2.46\end{array}$ & $\begin{array}{l}2.15 \\
2.18 \\
2.41\end{array}$ \\
\hline & & 4 & 4 & (a) & 4.3 & 550 & .85 & 1.6 & 2.12 & 2.24 & 2.21 \\
\hline & & 4 & 5 & (a) & 4.2 & 550 & .84 & 1.6 & 2.15 & 2.26 & 2.20 \\
\hline \multirow[t]{3}{*}{$4065-84$} & $\begin{array}{l}\mathrm{B}_{4} \mathrm{C} \text { granules } \\
\text { Natural Boron } \\
76 \text { wt }-\% \text { B }\end{array}$ & - & - & $\begin{array}{l}\text { unirrad } \\
\text { (a) }\end{array}$ & $\begin{array}{c}0 \\
4.4\end{array}$ & 500 & $\begin{array}{c}0 \\
.82\end{array}$ & $\begin{array}{c}0 \\
1.7\end{array}$ & $\begin{array}{l}2.43 \\
2.15\end{array}$ & $\begin{array}{l}2.52 \\
2.35\end{array}$ & $\begin{array}{l}2.49 \\
2.29\end{array}$ \\
\hline & & 1 & 5 & (a) & 4.6 & 500 & .84 & 1.7 & 2.09 & 2.22 & 2.16 \\
\hline & & 1 & 6 & (a) & 4.8 & 500 & $.61(\mathrm{e})$ & 1.2 & 2.11 & 2.27 & 2.22 \\
\hline \multirow[t]{3}{*}{$4465-7$} & $\mathrm{~B}_{4} \mathrm{C}$ granules & - & - & unirrad & 0 & - & 0 & 0 & 2.27 & 2.36 & 2.35 \\
\hline & $\begin{array}{l}\text { Boron entiched } \\
\text { in } B-10\end{array}$ & $\begin{array}{l}3 \\
3 \\
3\end{array}$ & $\begin{array}{l}3 \\
3 \\
3\end{array}$ & $\begin{array}{l}(a) \\
(b) \\
(c)\end{array}$ & $\begin{array}{l}5.9 \\
5.9 \\
5.9\end{array}$ & $\begin{array}{l}500 \\
500 \\
700\end{array}$ & $\begin{array}{l}.94 \\
.64(e) \\
.24(e)\end{array}$ & $\begin{array}{l}8.1 \\
5.6 \\
2.1\end{array}$ & $\begin{array}{l}1.90 \\
2.04 \\
2.07\end{array}$ & $\begin{array}{l}2.07 \\
2.18 \\
2.15\end{array}$ & $\begin{array}{l}2.00 \\
2.13 \\
2.09\end{array}$ \\
\hline & $\frac{B-10}{B-11}=11.5$ & $\begin{array}{l}4 \\
4\end{array}$ & $\begin{array}{l}3 \\
3\end{array}$ & (a) & $\begin{array}{l}4.5 \\
4.5\end{array}$ & $\begin{array}{l}550 \\
550\end{array}$ & $\begin{array}{l}.84 \\
.56\end{array}$ & $\begin{array}{l}7.3 \\
4.9\end{array}$ & $\begin{array}{l}2.03 \\
2.01\end{array}$ & $\begin{array}{l}2.21 \\
2.13\end{array}$ & $\begin{array}{l}2.08 \\
2.09\end{array}$ \\
\hline
\end{tabular}

(a) inshielded - fronk of crucible.

(b) Partially shielded atde of crucible.

(c) Completely shielded center of boronated graphite sample.

(d) Lstimated B-10 depletion from Fig. 9 except where noted as measured.

(e) Measured B-10 depletion.

(f) Determined by liquid density gradient column.

(g) vor measured but assumed to be approxtmately zero. 
The results of the work showed that density decrease during irradiation was not dependent on the boron content of the $\mathrm{B}_{4} \mathrm{C}$ or fast-neutron exposure. The decrease in density of all samples could be correlated with B-10 depletion or B-10 fission density. With natural boron the density decreased approximately linearly with B-10 fission density as shown in Fig. 11.25.

A simple linear regression fit of the natural boron $\mathrm{B}_{4} \mathrm{C}$ data predicts a maximum of $13 \%$ decrease in density at $100 \% \mathrm{~B}-10$ depletion. With $\mathrm{B}_{4} \mathrm{C}$ made from B-10-enriched boron the decrease in density apparently saturates or decreases slowly after a fission density of about $2 \times 10^{22}$ B-10 fission/cm ${ }^{3}$ $\mathrm{B}_{4} \mathrm{C}$ is exceeded. The density decrease observed in this work is less than would be predicted on the basis of work reported previously (Ref.5) in which a 30 vol-\% increase took place in unrestrained $\mathrm{B}_{4} \mathrm{C}$ spheres irradiated at $500^{\circ} \mathrm{C}$ to a $\mathrm{B}-10$ burn-up of $78 \%$. Other irradiation results with large hot-pressed shapes of $\mathrm{B}_{4} \mathrm{C}$ resulted in greater expansion than observed here (Ref. 6). There is no obvious explanation for the difference in observation.

\section{Boron Fibers}

Boron filament (3471-122), which is commercially available, is interesting as a high-strength, high-modulus, reinforcing material with neutron absorbing properties. Samples were included in the piggyback position of BG-2 to confirm the predicted poor performance at very high B-10 burnup.

The material is made by vapor depositing elemental boron on a $0.005-i n$. diameter tungsten wire to form a filament with a 0.004-in. diameter. During irradiation at $550 \pm 50^{\circ} \mathrm{C}$ to a B-10 burnup of about $65 \%$, the boron fragmented and very few remnants of the original fibers were recovered. A photograph of unirradiated and irradiated boron fibers is shown in Fig. 11.26. Portions of the tungsten substrate can be seen in some fragments of the irradiated fibers. The predicted poor performance of the fibers at high $B-10$ burnup was confirmed. 


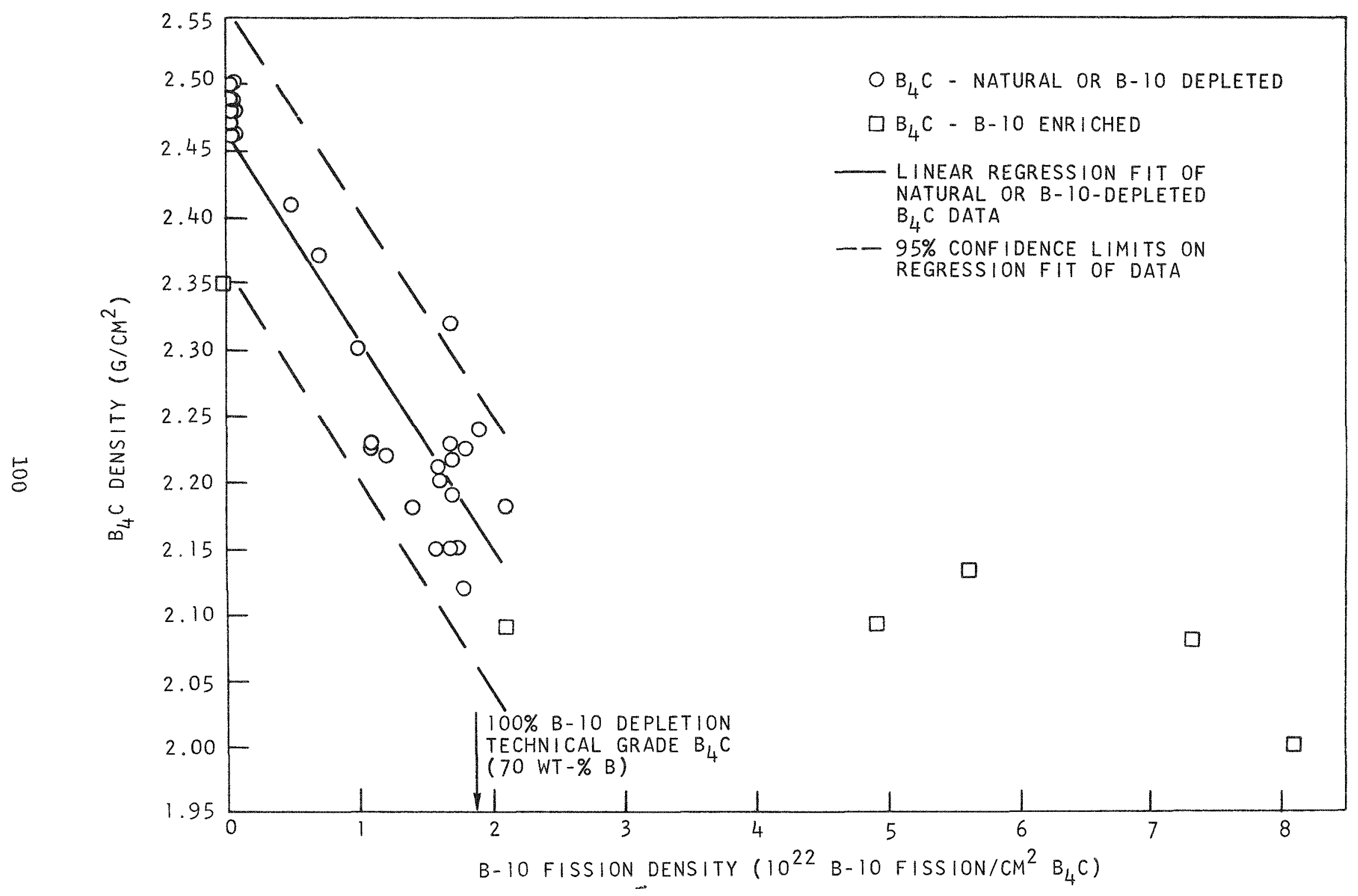

Fig. 11.25. Effect of B-10 fission density on the density of $\mathrm{B}_{4} \mathrm{C}$ irradiated in piggyback location of $\mathrm{BG}-2$; a simple linear regression fit of the data for $\mathrm{B}_{4} \mathrm{C}$ containing natural or depleted boron is shown 

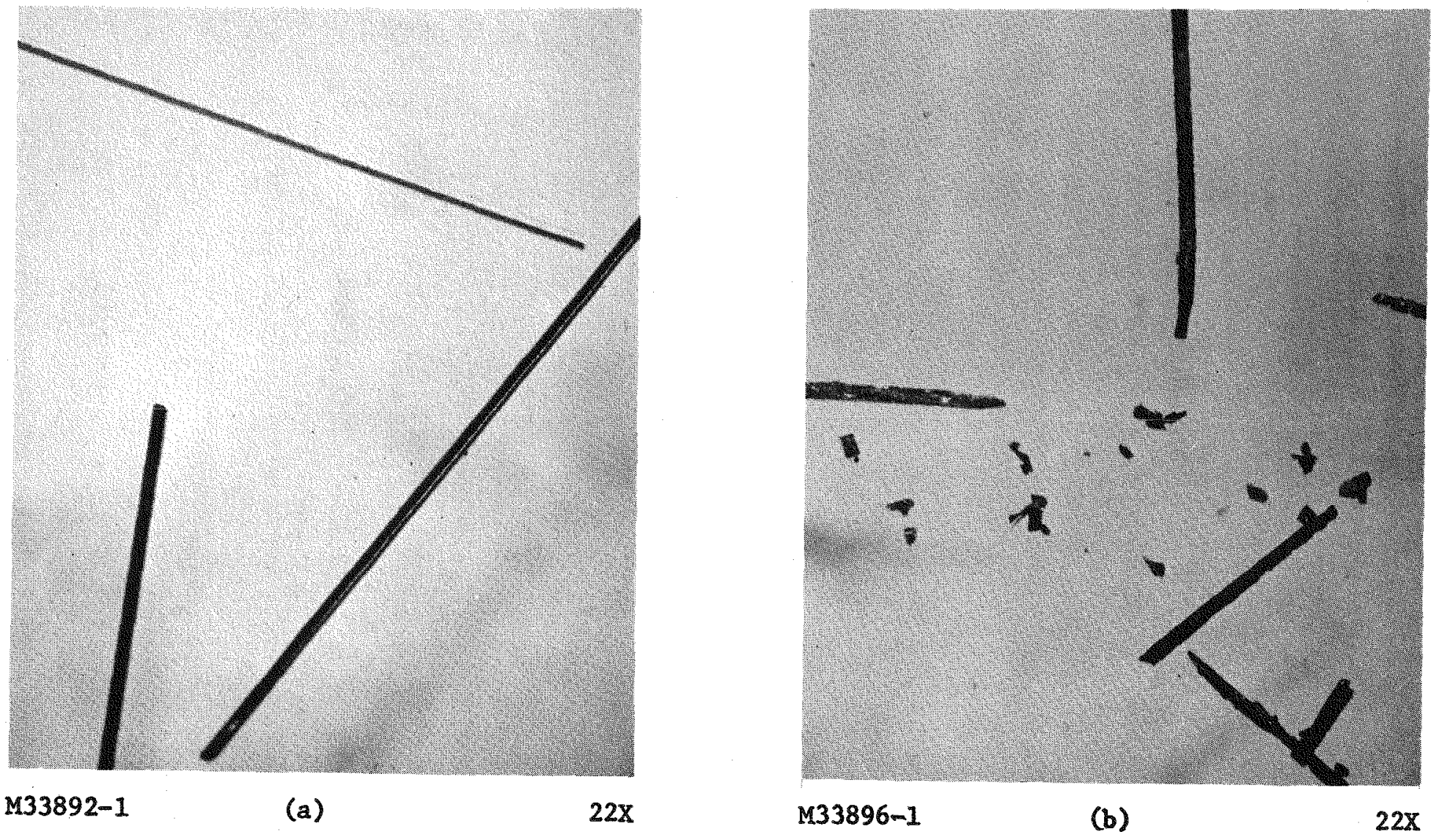

Fig. 11.26. Boron filament (material 3471-122, specimen 235) 0.004-in.-diameter vapor-deposited boron on 0.0005-in.-diametex tungsten wire: (a) before irradiation; (b) after irradiation in capsule $\mathrm{BG}-2$ at $550 \pm 50^{\circ} \mathrm{C}$ to a fast-neutron exposure of $5.8 \times 10^{21} \mathrm{n} / \mathrm{cm}^{2}(\mathrm{E}>0.18 \mathrm{Mev})$ and $\mathrm{B}-10$ burnup of $65 \%$. Reactor exposure resulted in splitting and fragmentation of filament 
Hafnium Carbide

Hafnium carbide was of interest because of its neutron absorbing and extremely refractory nature. Loose granules of $\mathrm{HfC}$ were included in piggyback specimens to provide information on the individual contribution of irradiation effects in HfC to the irradiation effects observed in hafnated graphite (HfC + graphite).

The material (4065-111) irradiated in capsule BG-2 was HfC granules, diameter 200 to $300 \mu \mathrm{m}$, contaning $90 \mathrm{wt}-\% \mathrm{Hf}, 2.8 \mathrm{wt}-\% \mathrm{Zr}$, the remainder being carbon. The spectrographic analysis is given in Table 11.5. It has erroneously been reported (see quarterly report GA-9660) that two different $\mathrm{HfC}$ materials were being irradiated. The samples were irradiated at $550 \pm$ $50^{\circ} \mathrm{C}$ to a fast-neutron exposure of 5.5 to $6.0 \times 10^{21} \mathrm{n} / \mathrm{cm}^{2}(\mathrm{E}>0.18 \mathrm{Mev})$. After irradiation the samples were retrieved remotely (radioactivity about $100 \mathrm{R}$ at $2 \mathrm{in.)}$ from the graphite crucibles by breaking the crucible top off and pouring the granules out. Most granules remained packed in the graphite crucibles, but a portion did pour out and the individual grains showed no sign of agglomeration or change, other than a darkening, from the unirradiated state as shown in Fig. 11.27. A polished cross section of one of the crucibles is shown in Fig. 11.28. No damage was observed in the graphite crucible. A typical microstructure of $\mathrm{HfC}$ before and after irradiation is shown in Fig. 11.29. No change in morphology was detectable from the unirradiated state. A distinctive second phase existed in the grain boundaries of some HfC granules. Electron microprobe examination of these areas in unirradiated HfC showed that they were relatively high in $\mathrm{Fe}, \mathrm{Cr}$, and $\mathrm{Ni}$ content and probably represented a low-melting-point impurity phase rejected from the HfC. 

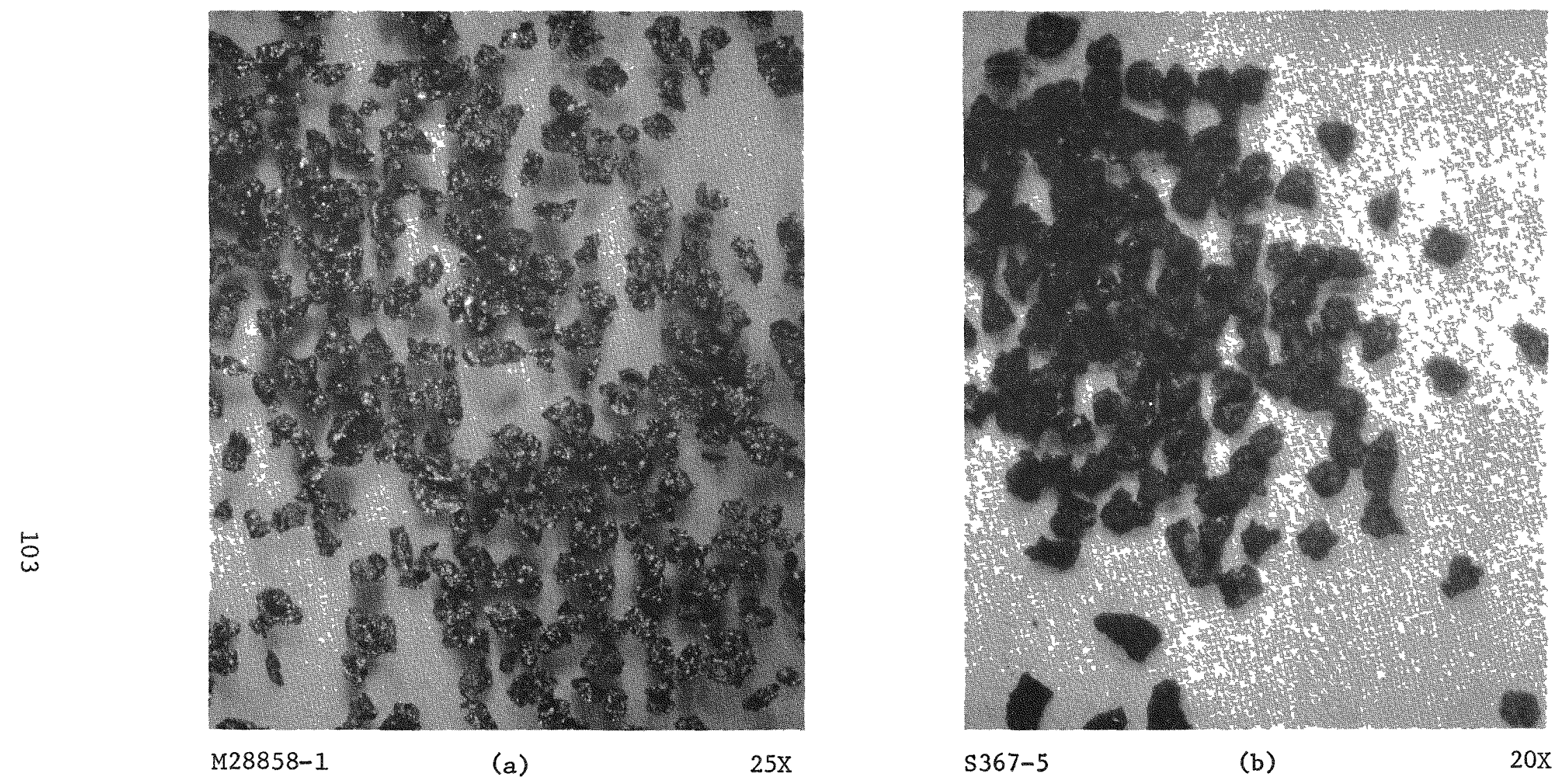

Fig. 11.27. Hafnium carbide (4065-111, specimen 2-1-S): (a) unirradiated $-48+200$ mesh U.S.; (b) irradiated in $\mathrm{BG}-2$ at $550 \pm 50^{\circ} \mathrm{C}$ to a fast-neutron exposure of $5.5 \times 10^{21} \mathrm{n} / \mathrm{cm}^{2}(\mathrm{E}>0.18 \mathrm{Mev})$. Before irradiation sample was screened to $-48+65$ mesh U.S. ( $200-$ to $300-\mu \mathrm{m}$ size range). During irradiation there was darkening and loss of reflectivity, no other changes evident 


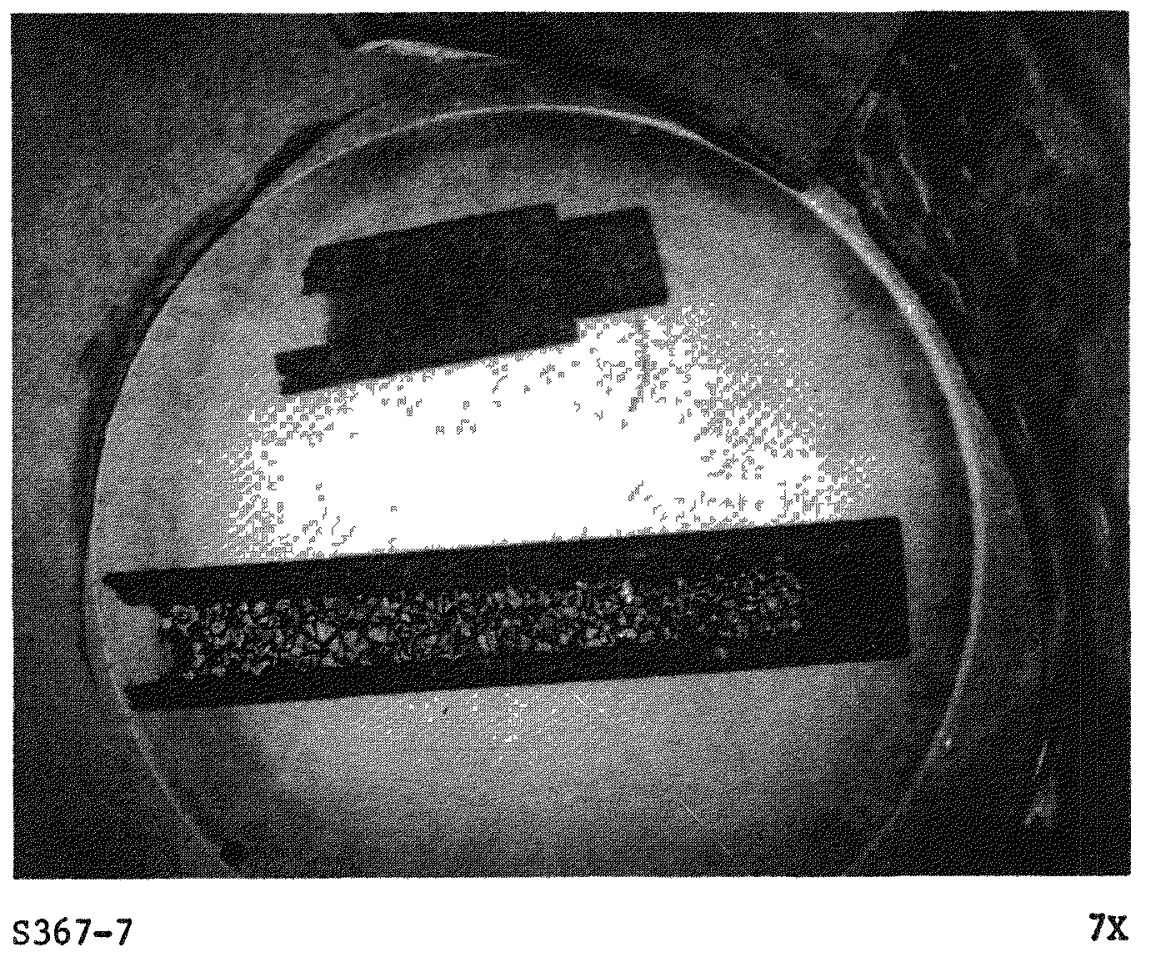

Fig. 11.28. Metallographic cross section of hafnium carbide granules (4065-111, specimen 2-7) in an opened piggyback crucible from capsule BG-2 after irradiation at $550 \pm 50^{\circ} \mathrm{C}$ to a fast-neutron exposure of $6.0 \times 10^{21}$ ( $\mathrm{E}>0.18 \mathrm{Mev}$ ). Top was broken off and contents poured out before mounting. No damage was evident in either top or bottom portion of graphite crucible 


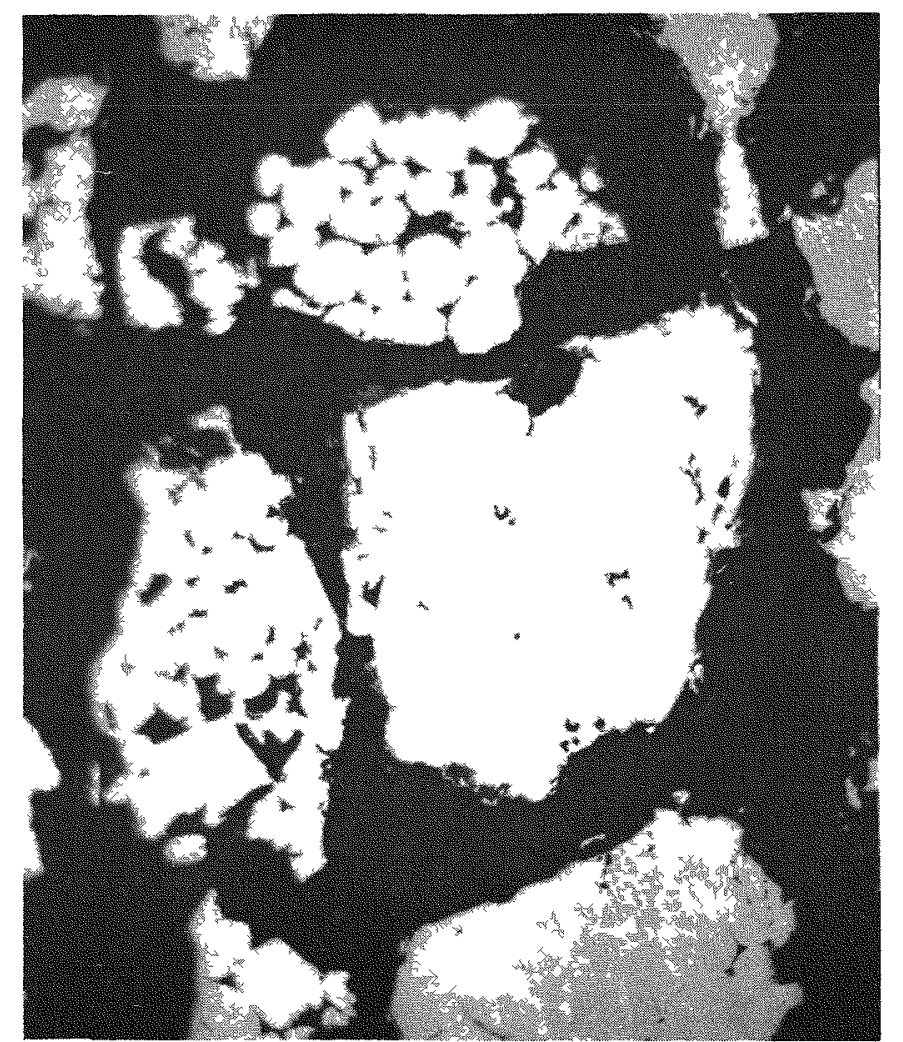

M367-252

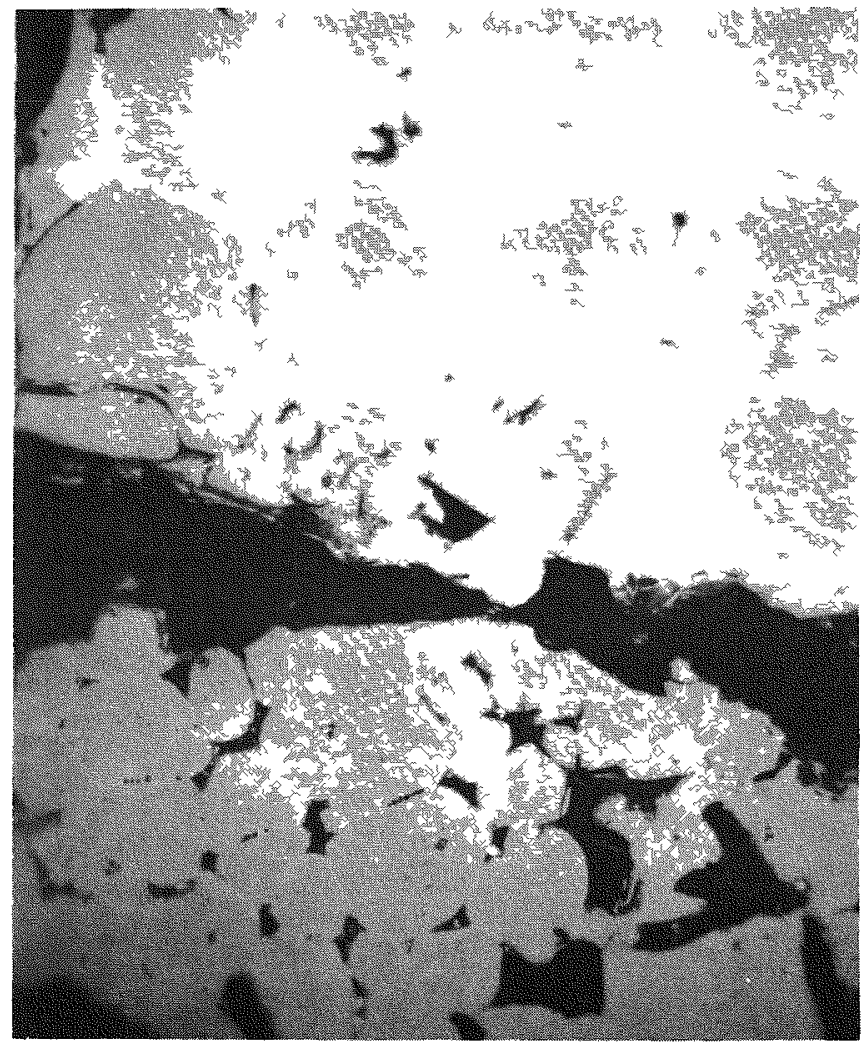

M267-250

Fig. 11.29. Microstructure of hafnium carbide (4065-111, specimen 2-1-S) irradiated in capsule BG-2 piggyback location at $550 \pm 50^{\circ} \mathrm{C}$ to a fast-neutron exposure of $5.5 \times 10^{21} \mathrm{n} / \mathrm{cm}^{2}(\mathrm{E}>0.18$ Mev). No change detected in grain morphology during irradiation; white intergranular phase identified in unirradiated samples as having high $\mathrm{Fe}, \mathrm{Cr}$, and $\mathrm{Ni}$ content 
TABLE 11.5

SPECTROGRAPHIC ANALYSIS OF HAFNIUM CARBIDE

\begin{tabular}{c|c|c|c}
\hline Element & $\begin{array}{c}\text { Amount } \\
\text { (ppm) }\end{array}$ & Element & $\begin{array}{c}\text { Amount } \\
\text { (ppm) }\end{array}$ \\
\hline $\mathrm{Al}$ & 225 & $\mathrm{~N}$ & 824 \\
$\mathrm{~B}$ & 0.8 & $\mathrm{Ni}$ & 200 \\
$\mathrm{Cb}$ & $<100$ & $\mathrm{O}$ & 1900 \\
$\mathrm{Cd}$ & $<1$ & $\mathrm{~Pb}$ & $<5$ \\
$\mathrm{Co}$ & $<5$ & $\mathrm{Si}$ & $<40$ \\
$\mathrm{Cr}$ & 500 & $\mathrm{Sn}$ & 10 \\
$\mathrm{Cu}$ & $<40$ & $\mathrm{Ta}$ & $<200$ \\
$\mathrm{Fe}$ & 1800 & $\mathrm{Ti}$ & 1000 \\
$\mathrm{Mg}$ & $<10$ & $\mathrm{~V}$ & 5 \\
$\mathrm{Mn}$ & $<10$ & $\mathrm{~W}$ & $<20$ \\
$\mathrm{Mo}$ & 25 & $\mathrm{C}$ & $5.92(\mathrm{a})$ \\
\hline
\end{tabular}

(a) Analysis in \%

\section{REFERENCES}

1. Kaae, J. L., D. W. Stevens, and J. C. Bokros, "Dimensional Changes Induced in Poorly Crystalline Isotropic Carbons by Radiation," USAEC Report GA-10518, Gulf General Atomic, to be published.

2. Stansfield, O. M., and N. L. Sandefur, "Irradiation-Induced Dimensional Change in Boronated Graphite, Results of the BG-1 (GA-19-1) Experiment," USAEC Report GAMD-9276, Gulf General Atomic, July 29, 1969.

3. White, J. L., and K. Koyama, "Graphitic Materials Hot-Worked with a Dispersed Liquid Carbide: Thermal and Electrical Conductivity," J.Am. Ceram. Soc, 51, 394 (1968).

4. Kubaschewski, O., and E. L. Evans, Metallurgical Thermochemistry, 3rd Ed., Pergamon Press, London, 1958.

5. Stansfield, O. M., "Irradiation-Induced Dimensional Change in Boron Carbide," J. Nucl. Materia1s, 31, 351-355 (1969).

6. Evans, T. W., "The Effects of Irradiation on Boron Carbide, A Literature Review," Report BNWL-679, February 1968. 
Appendix

PROJECT REPORTS PUBLISHED DURING THE QUARTER

1. Luby, C. S., D. P. Harmon, and W. V. Goeddel, "HTGR Fuel Design and Irradiation Performance," USAEC Report GA-10468, Gulf General Atomic, January 5, 1971 . 